\section{The Portrayal of Immigration in Nineteenth Century Argentine Fiction (1845-1902)}

Immigration was the keystone of modern Argentina, transforming a rather backward, underdeveloped country into one of the most rapidly growing nations in the Western World in the course of the second half of the nineteenth century. This study, focusing upon eight central texts of the period, investigates the impact of immigration upon the country's intellectual scene, the reactions that it elicited, the fears, the hopes, and the prejudices that it nurtured, and the changes in the ideological climate which it brought in its wake. The period under scrutiny, 1845-1902, covers the earliest discussions of massive immigration in the abstract through a phase of fierce xenophobia, to the time when the first immigrants had made their dramatic imprint upon the country against a background of emerging national consciousness, and ideas of cultural integration regained currency. Attitudes towards immigration are seen to move between the extreme positions of Civilisation (those regarding the influx as a 



B I B L I O T H E C A I B E R O - A M ER I C A N A

E V ELYN FIS HBURN

The Portrayal

of Immigration

in Nineteenth Century

Argentine Fiction

(1845-1902)

COLLOQUIUM VERLAG BERLIN 1981 
For F.J.F.

CIP-Kurztitelaufnahme der Deutschen Bibliothek

Fishburn, Evelyn:

The portrayal of immigration in nineteenth century Argentine fiction: (1845-1902) /

Evelyn Fishburn. - Berlin: Colloquium-Verlag, 1981.

(Bibliotheca Ibero-Americana; Bd. 29)

ISBN 3-7678-0523-5.

NE: GT

(c) 1981 Colloquium Verlag Otto H. Hess

Satz: Gleißberg \& Wittstock, Berlin

Druck: Color-Druck, Berlin

Schrift: Garamont

Printed in Germany 
(a) 


\section{B I B L I O T H E C A I B E R O-A M ER I C A N A}

Veröffentlichungen des Ibero-Amerikanischen Instituts

Preußischer Kulturbesitz

Herausgegeben von Wilhelm Stegmann

Band 29 
This thesis examines the portrayal of immigration in nineteenth century Argentine fiction. It focuses on the eight most important works in which immigration is the central theme. Each of these works is analyzed individually and the presentation of immigration is considered against the overall context of such work.

The thesis is divided into three consecutive periods, 1845-1880, 1880-1890, and 1890-1902. These divisions are not arbitrary, but coincide with changes of attitude.

The first period produced works in which immigration is still considered in the abstract. The immigrant is regarded as a civilizing influence, which would not only provide an industrious work force, but which would, by example and through miscegenation, also improve in racial terms the gaucho or mestizo element of the population.

During the second period works were written at a time when massive immigration was beginning to arrive in Argentina and was making its initial impact upon the existing small criollo population. A fierce reaction develops and the immigrant is now depicted as physically and morally inferior, a dangerous invader against whose contaminating influence the indigenous population must be warned.

In the third and final period immigration is portrayed against the emerging affirmation of national consciousness. With immigration an established fact, a return is seen towards the idea of integrating the two cultures. The immigrant is no longer presented as a civilizing influence, but a more ambiguous, less clearly defined attitude appears in which the immigrant, though welcomed for his energy and industry, is expected to adopt the idealized values and lifestyle which are ascribed to a superior criollo population.

The conclusion is reached that, contrary to previous interpretations that immigration was treated with realistic and naturalistic objectivity, it was, in fact, portrayed in a manner which was selective, rhetorical, and prescriptive. A stereotype is created of an immigrant who arrives poor and becomes rich, and who is evaluated on racial and cultural bases. Even the one work written by an immigrant provides only a partial exception to these conclusions.

An historical background to immigration is provided in an Appendix. 


\section{ACKNOWLEDGEMENTS}

I would like to express my gratitude: -

to my Supervisor, Nissa Torrents, for giving so generously both of her time and her learning; for the stimulus of her company and for her friendship;

to Prof. J.S. Cummins, for his advice, encouragement and faith in me;

to Prof. J. Lynch, for reading the Appendix and making many valuable comments;

to Dr. E. Ortiz, for the interest shown and information supplied by him, particularly in the early stages of this thesis;

to my husband, Freddy, for his help, support and endurance;

to my daughters, Barbara, Alexandra and Simone, for their cooperation and tolerance. 
Immigration was the keystone of modern Argentina. It was the single most important event in the transformational process which in the second half of the nineteenth century changed Argentina from a rather backward, underdeveloped country into one of the most rapidly growing nations of the Western World. The size of this immigration, unparalleled in the Hispanic continent, was such that it altered not only the face of Argentina, but bit into the very essence of society deeply affecting its ethnic composition, its demographic distribution, its values and its way of life.

The impact of Immigration has been noted in other areas, but has received little attention in the study of literature. My purpose in this thesis is to investigate the portrayal of Immigration in nineteenth century works of fiction in order to gain an insight into the effect that it had upon the country's intellectual scene, the reactions that it elicited, the fears, the hopes, and the prejudices that it nurtured, and the changes in the ideological climate which it brought in its wake.

In this study, I shall be concerned primarily with the way in which Immigration was viewed and recorded in selected novels in which it constitutes a central theme. The depiction of immigrant characters will be placed next to that of other groups, and any differences, either of attitude or of language, will be noted. Furthermore, the ideological framework of each novel will be examined and the role of Immigration considered against this overall background.

The choice of material, limited to the study of eight novels written between 1845 and 1902, requires a few words of explanation. The existing bibliography on the subject is small, the only two important works to date being La inmigración en la literatura argentina, $1880-1910^{l}$ by Gladys Onega, and El inmigrante italiano en la novela del $80^{2}$ by Luciano Rusich. The first is a comprehensive study, examining the portrayal of Immigration in all literary genres. It is a sociopolitical work which seeks to show the factional interests of the ruling groups as manifested in literature. The second, as indicated by its title, is concerned with listing all the instances in which an Italian immigrant character is to be found in the novel. It is exhaustive on its subject, but by extrapolating one element from the rest of the work and 
recording it in comparative isolation, it offers a picture of somewhat limited perspective.

In addition to these two major studies, there is a number of short essays ${ }^{3}$ but, as stated by Germán García in his invaluable bibliographical aid to research, El inmigrante en la novela argentina, the subject is still surprisingly unexplored. Concurring with him that, lo más valioso... es lo que se escribió en la época misma del fenómeno aluvional ${ }^{4}{ }^{4}$ I have decided to concentrate my research on a selected number of works written at the time when Immigration was the predominant preoccupation in Argentina. The dates chosen, 1845-1902, span the period from when the question of massive Immigration is discussed in the abstract, to the time when the first waves of immigrants arrived and made their dramatic imprint upon a sparse and expectant population. In viewing these two vital moments in the historical development of the country, my thesis will record the beginning of radical changes in the country's ideological outlook, tracing a noticeable shift from cosmopolitanism to nationalism.

The period is not one in which the literary output on the immigrant is numerically impressive. The eight works chosen constitute in fact most of the relevant literature. They are important, not only because of the information that they contain, but also because they predetermine the approach to Immigration in literature and create the prototypes of future immigrant characters. After the turn of the century immigrants are seldom absent from the literary scene, but they no longer occupy the focal point of interest, this having moved largely to questions of cultural values in a quest for a new national identity.

It still remains to justify the selection of narrative fiction as the single literary genre included. In fact the choice lay only between the theatre and the novel, since the short story did not flourish until somewhat later, and poetry remained largely unconcerned with the subject. ${ }^{5}$ In contrast, the theatre offered a rich and varied source of material in which both criollo and immigrant viewpoints are expressed. Being an essentially popular art form, it was more immediately accessible to the immigrant population itself, who soon became its protagonist, its audience and often its writers. It therefore evolved differently from the novel, and requires separate study. ${ }^{6}$

The novel, with its scope for complexity, offered a fascination of its own. Written by one group of people about another of which they knew very little and for which they cared (in human terms) even less, it constitutes a most valuable source of information regarding the prevailing ideological climate in Argentina. Largely unhindered by aesthetic preoccupations or 
factual concern, the works chosen reveal most faithfully the underlying tensions that were felt by a society at a crucial moment of its history. In agreement with Lucien Goldman, it could be argued that the weaker the creative force of the writer, the more accurate is the transposition of social reality and of collective consciousness in his work. ${ }^{7}$ Regarding the latter, the collective consciousness revealed will prove to have been largely that of the criollo élite, the social group to which the writers of the works chosen belonged or at least with which they identified. The feelings of the criollo masses are not expressed in the novels studied.

Regarding social reality, this should not be sought either in the plots or in the characterization of their protagonists. Contrary to the interpretations of the majority of critics who talk about the Realism of the novels studied in traditional terms, one of the tenets of this thesis is that only the most tenuous links exist between the novels and the contemporary reality they purport to describe. The stories are, of course, set in the recognizable environment of Argentina in the late nineteenth century, but it is here submitted that they do not seek to reflect society but seem to be based upon deliberate distortions, figments of the author's imagination selected and shaped to propound a particular viewpoint. The social reality revealed, therefore, is the author's, to be found in his rhetoric, and in the way in which he chooses to portray immigration. Roland Barthes's assertion that the tale is always in the telling ${ }^{8}$ seems particularly apposite in this context. But if the literature studied does little to describe Immigration as it occured, it is important as a means of examining Immigration as it was felt, if not by of society, at least by some of the self-appointed representatives of its ruling group.

Work and race are the predominant themes regarding Immigration reflected in the novels studied. This is in keeping with the main purpose of the Immigration Policy which, with its twin directives of populating the desert and whitening the population, aimed at attracting a sizeable labour force which would both advance the country's economic development and also provide a massive injection of European blood to alter the racial composition of much of the existing population. The problem having been posed originally by Sarmiento in contrasting terms of Civilization and Barbarism, Immigration itself is viewed alternatively, either positively, as a redeeming civilizing influence, or negatively, as a disruptive barbaric invasion of nefarious consequences.

In the light of these attitudes, the thesis is divided into three sections. Part One seeks to examine the early period in which Immigration was still an abstract project, a policy to be advocated with fervour and conviction. Its 
title, the Pre-Immigration Period, is used purely in a literary sense and refers to the fact that in the works studied in this section there are no immigrant characters as such. It does not seek to imply that there were no immigrants in Argentina at that time for, although massive immigration had not yet begun, this was clearly not the case. Part Two examines the period from 1880 to 1890 , in which the first waves of immigrants began to arrive in large numbers. It records a reaction of fear in the face of change and also of suspicion that the poor, ignorant, and illiterate peasants who were arriving in such masses, might not fulfil the idealistic forecasts made about them by writers such as Sarmiento and Alberdi. In an effort to stem the flood of immigration, a campaign was started in which the racist element of Positivist thought was invoked. The main argument was that immigrants were people of inferior quality who, far from improving the existing population, constituted a grave danger of contaminating it, both physically, through their weakened and degenerate blood, and morally, through their impure, materialistic way of life. Part Three examines the years following the crisis of 1890 in which the country suffered a major economic setback. It is a moment of reappraisal, in which the economic advantages offered by a large foreign work force have to be weighed against the obvious threats that change will impose upon the ruling groups. These are peak years of immigration, and of renewed economic prosperity. A new positive attitude evolves in the novel, in which the doleful strictures of biological determinism give way to a more accommodating belief in the influence of the environment. What is of paramount importance, however, in this new attitude towards immigration, is the detection of the terms upon which approval is given. It will be seen that, contrary to the experience in the U.S.A., in which immigrants are accepted as such and dual loyalties to country of origin and country of adoption are allowed to coexist, the model immigrant in Argentina is portrayed as the one who is prepared to succumb to the beneficial influence of Argentina, shedding his immigrant qualities in order to emerge as the perfect new criollo. As in the literature studied in the previous section, the problems relating to Immigration are not tackled directly, but are transported onto an either scientific or a moral plane. The political and cultural tensions which ensued from massive immigration are thus resolved in an unrealistic and over-idealized fashion. The real immigrant, it will be shown, remains almost unrepresented.

Since there exists no general History of Argentine Immigration to which the reader could be referred in support of the thesis that the literature under review is not an objective portrayal of immigration, I include an 
Appendix in which some background information on this subject is given. This Appendix or additional chapter is divided into two sections, the first attempting to summarize the role of Immigration in the general framework of Argentine history, and the second focusing more closely on the different aspects of Immigration in the development of the social, economic, and political life of Argentina in the period studied. 

PARTONE

THE PRE-IMMIGRATION PERIOD 



\section{I * "FACUNDO: CIVILISAZIÓN y BARBARIE"}

The Novel was a relative latecomer on the Latin American literary scene. Traditionally the last genre to develop in any society, its flowering was delayed in Colonial America by Royal Decrees. ${ }^{1}$ The Crown feared it lest it divert interest from the Holy Scriptures, and banned it as a frivolous, even pernicious influence. However, this did not stop great quantities of novels from being smuggled into the colonies but none was printed in the Continent itself, and no tradition of the novel was established. ${ }^{2}$

When at last the novel began to flourish in the nineteenth century, it was largely a serious art form which emerged, with didactic tendencies, often grave and rhetorical in its expression. ${ }^{3}$ In Argentina, most of the earliest novels were politically biased works written by authors of high social standing who had been brought up in the cultural tradition of Western Europe. Mostly they are pro-Unitarian works ${ }^{4}$ aimed at ending the tyranny of the Federalist dictator Juan Manuel de Rosas whose main aim was to subjugate the country under his exclusive rule and close its frontiers to outside influences.

Since European immigration was one of the prominent features of Unitarian policy, these early novels are either implicitly or explicitly supporters of Immigration. The most important works of this period are ElMatadero, Amalia, and Facundo. Sharing the assumptions of many lesser known contemporary works, they offer a cohesive picture of Unitarian bias in favour of all that was European, whether in race, ideas, or fashion. ElMatadero is a short story written approximately around 1839 by Esteban Echeverría, included here in passing merely as a brief illustration of the clear-cut division that permeates the prose writings of the period under review in which the existing political opposition of federales and unitarios is transposed onto the human level. The former are always portrayed as an uncouth, even savage, element of society, dark, primitive, and retrograde, and the latter as their complete reversal: a fair, educated, delicately sensitive people, who display an inborne quality of leadership. In ElMatadero, an allegorical story centred around the havoc caused by a meat shortage during the Lenten period in Buenos Aires, the federales are likened to base animals, greedy in their rapacious lust for food, and brutal, not only in their accidental killing of a child whilst trying to catch a bull for slaughter, 
but even more so in their sadistic goading of a young innocent unitario, whose elegance and self-assurance they felt an open affront. It is interesting to compare the description of the dark rabble that constitutes the Federalist following of Rosas, of which ugliness is the overriding characteristic: 'cuya fealdad trasuntaba las harpías de la fábula', with the innocent, handsome looks of the young unitario: 'era éste un joven como de 25 años, de gallarda y bien apuesta persona'. 6 There is no attempt to delve into the background which determined the social and political differences of these two polarized groups, and Echeverría limits himself to expose the terror and the barbarism of the Rosas regime and to condemn it in terms which are purely moral. ${ }^{7}$

In Amalia, ${ }^{8}$ a long novel written in exile by José Mármol with the specific aim of bringing about the downfall of Rosas, there is a similar manichean division between the evil federales and the good unitarios which permeates the structure of the work, its language, imagery and characterisation. The same moral value judgements persist, pronouncing with unquestioning authority the worthiness of the Europeanised unitarios and the evil of the federales. The relevance of all this to the portrayal of immigration in literature becomes clear if one considers the wider implications of the above assumptions. For if all that is autochthonous is bad, and all that is European is good, the obvious correlative is that it would be in the nation's interest to increase the European quotient whilst minimizing the criollo's retrograde influence upon the country's evolution. This idea, which is merely hinted at in El Matadero and in Amalia, is expressed with forthright conviction in Sarmiento's most memorable work, Facundo: Civilización y barbarie. ${ }^{9}$ Here, the plea for immigration becomes overt; after vibrating in and between every one of its lines, it reaches its final eruption in the concluding pages in which Sarmiento solemnly declares:

El día, pues, que un gobierno dirija a objetos de utilidad nacional los millones que hoy se gastan en hacer guerras desastrosas e inútiles y en pagar criminales; el día que por toda Europa se sepa que el horrible monstruo que hoy desola la República y está gritando diariamente 'imuerte a los extranjeros!' ha desaparecido, ese día la emigración industriosa de la Europa se dirigirá en masa al Río de la Plata; el 'Nuevo Gobierno' se encargará de distribuirla por las provincias; los ingenieros de la República irán a trazar en todos los puntos convenientes los planos de las ciudades y villas que deberán construir para su residencia, y terrenos feraces les serán adjudicados, y en diez años quedarán todas las márgenes de los ríos cubiertas de ciudades, y la República doblará su población con vecinos activos, morales e industriosos. Éstas no sun quimeras, pues basta quererlo y que haya un gobierno menos brutal que el presente para conseguirlo. (pp. 285-6) 
Facundo is one of the most influential works to have been written in Spanish America in the nineteenth century. Its importance with respect to the question of immigration cannot be stressed sufficiently, since the whole work is built upon the axiomatic assumption of the superiority of the European races over the native Americans. Its goal is ultimately to see the replacement of the latter by an industrious, clean living, cultured European work force. No other work will advocate immigration with the same wholehearted enthusiasm.

Sarmiento's plea can be traced in the conceptual framework of Facundo, in his denigration of Barbarism, in his praise for Civilization, and finally, in his prognostications of a future in which the aims of a cosmopolitan liberal policy will be fulfilled. In the following pages, these points will be analyzed in detail and, where relevant, examined in the light of existing criticism. Facundo was written by Sarmiento in Chile during the author's exile from Rosas's dictatorship. It was first published in daily instalments in the Chilean newspaper El Progreso from 2 May to 28 July 1845, and in book form later that year. It has been the object of numerous subsequent publications, and of translations into several European languages. ${ }^{11}$ Although a difficult work to place into any one category, being a sociological study, a biography, and a historical account, Facundo has generally been accepted as a novel. ${ }^{12}$ Its fictional content is easily detected since its information is unreliable, inaccurate, and deliberately slanted, ${ }^{13}$ and, if it has endured the test of time this is due not only to its documentary value but chiefly to the high aesthetic intent and achievement of the work.

The story evolves around the life of a self-elected caudillo, Facundo Quiroga, who spread his reign of terror over many of Argentina's interior provinces, finally to succumb to the greater power of Juan Manuel de Rosas, who was first Governor of Buenos Aires and later dictator of the whole country. Anticipating Taine's deterministic theory about the interrelated influence of race, environment, and historical moment, (as systematized in his Introduction to the History of English Literature) $)^{14}$ Sarmiento, who writes not only earlier, but from the comparative cultural isolation of Chile, shows his knowledge and understanding of current European ideas in the causal approach which constitutes both the conceptual background and the organizational structure of Facundo.

The work is one of the first written in Latin America which is not anthropocentric in its outlook, but which, in tune with the scientifically orientated ideas of the century, takes in the whole of the surrounding reality as an influencing factor in the evolution of society. Thus, Man for Sarmiento is not the product of the immutable moral characteristics of 
Classical thought, but is open to constant changes produced by a universe which is itself in a flux of constant change. Coinciding with Darwinian thought, everything in Facundo is seen in strict hierarchical terms in which change seems synonymous with progress. The basic thought is that nature can be improved by civilization and man can rise in the evolutionary ladder by adapting to the improving conditions of a more complex economy of which urban industrialization was considered the zenith. Reminiscent of Darwin's findings in his Origins of Species, there is in Sarmiento's universe a strong suggestion of hierarchical order in which the lower species will naturally and rightfully become extinct and make room for more suitable newcomers. The ones whose passage in the evolutionary process must come to an end are the gauchos, ${ }^{15}$ to be replaced by the higher ranking species of European immigrants. Only some of the most malleable inhabitants, the most able to adapt themselves to the evolving conditions, would survive in their changed form. ${ }^{16}$

Thus, placed against a conceptual framework of evolution in the exclusive direction of Europe, the commitment is clear in Facundo that Argentina must turn its back upon the Interior and look towards Europe for the future. The political programme which lies behind Facundo is discussed more fully in the Appendix, but a short summary may be considered appropriate here. Unitarian policy (and Sarmiento was to become one of its most prominent leaders) aimed at concentrating the country's efforts away from the backward Interior with its rudimentary industries demanding protective barriers, and onto the Littoral Provinces, that offered a seemingly limitless potential in agricultural yield. So far it could be said to overlap with the policies of the landowning Federalists of the Littoral Provinces. But the ultimate aim of the Unitarians was to develop an export orientated agriculture with a view to establishing commercial interchange with Europe. The latter would send its cheap, modern manufactured goods in return for Argentine meat and wheat. All this traffic would pass through the port of Buenos Aires and yield a high and easily controlled revenue which the Unitarians promised to share among the nation as a whole. Such a programme, however, needed foreign investment, foreign technology, and a foreign labour force. In order to attract any of these, the country would first have to be pacified and placed under the firm command of a Buenos Aires government.

It is in order to implement this policy that Sarmiento embarks upon his attack on what he has immortalized as 'la barbarie del Interior'. He dwells upon the barbarism of the gauchos, because he sees in them a severe obstacle to the unification of the country. Because of their blind allegiance to the 
local caudillos, who supported factional interests, he considers them a disruptive element in the implementation of a national policy. Furthermore, he seeks to undermine their accustomed way of life, which, nomadic, independent, disdainful of any work that does not require horsemanship and valour, seems to Sarmiento far from ideally suited to provide a docile labour force with which to build up the country's economy. To exchange inferior criollos for superior Europeans remains one of the main underlying themes of Facundo.

The work is divided into two parts: the first deals with the natural setting for the events to be described, giving detailed descriptions of the land and its physical aspects; of the inhabitants and their racial characteristics, and of the history of Argentina up to the time of Quiroga. The second recounts the barbarous deeds of the eponymous hero during the internecine wars of the post-Independence period. The last two chapters, set after the death of Quiroga, form almost a sub-section, dealing with the atrocities of the Rosas regime, but ending with an optimistic appraisal of its aftermath. This faith in a future 'Civilization', based upon a large immigrant population bringing orderliness and economic prosperity, is typical of the positive spirit which underlies even the darkest pages of Facundo. 'Facundo' is the title of the work; 'Civilización y barbarie' its subtitle. Underlying the thematic content of the work, there is a basic premise which sees Argentina divided in dichotomic terms of Civilization and Barbarism. These are emotive words whose obvious connotation reveal the deeply held prejudice of the author's ideas. As already mentioned, civilization for Sarmiento stemmed absolutely and unmistakably from Europe. Its guiding light was a sense of progress in the direction outlined above and one of the principal means of achieving this was through the introduction of large-scale white immigration. According to early Unitarian policy, the primary object of attracting immigration was to acquire a sizeable work force to develop the potentialities of the immensely fertile country, but this economic objective was accompanied by a second, no less important, aim: that of whitening the population and therefore diluting, or neutralizing, the influence of the rriollo $^{17}$ element of society. The negation of Civilization is Barbarism, and its eradication is the first, vital step on the path to Civilization.

In Facundo, Barbarism is first traced to the natural setting and then, adhering to a causal pattern, it is found, and attacked, in its inhabitants, the gauchos (pp. 46-7). Finally, it is epitomized in the leader of these gauchos, who is presented as the inevitable result of barbarism. "i Sombra terrible de Facundo, voy a evocarte para que, sacudiendo el ensangrentado polvo que 
cubre tus cenizas, te levantes a explicarnos la vida secreta y las convulsiones internas que desgarran las entrañas de un noble pueblo!' (p. 17): these are the opening words of Facundo, declaring the author's intention to use the biography of this indomitable caudillo as a vehicle to explain the history of his country, showing a sort of double interplay between cause and effect, for not only does the general explain the particular, but the reverse is also the case (p. 26).

Barbarism is the American component of society, to be found principally amid the outsize, inhospitable, countryside of Argentina, which Sarmiento affirms could not fail to produce the rude, primitive and even savage people that inhabit it. In Sarmiento's eyes, not only does the struggle against a daunting nature conspire towards the barbarism of its inhabitants, with isolation leading to ignorance, but even the type of work which people are called upon to do in the barbarous countryside, in which killing animals and the shedding of their blood are everyday occurrences, is an added factor contributing towards an ethos of unfeeling cruelty. There is no Rousseaunian admiration for those who live close to Nature, any more than there is for Nature itself, which Sarmiento invokes, originally not out of any particular delight in its beauty, nor with any exalted romantic conception of proposing a return to it, but simply as part of the deterministic method which describes the setting in order to explain the society. ${ }^{18}$ Its grandeur is seen mainly as a matter of size, a hindrance of sociability and education. Far from decrying any tampering with the simplicity of Nature, he cites as an example worth emulating the efforts of the German and Swiss colonies that, in the southern part of the Province of Buenos Aires, have built small foci of civilization in the midst of the pampas, and whose most successful members were rewarded with the comforts of the city (pp. 37-9).

The gauchos' way of life is described in the first few chapters together with the terrain and its physical peculiarities, as if the inhabitants were a natural extension of the setting. At best they are portrayed as picturesque curiosities of a bygone age, and at worst they are condemned as primitive obstacles retarding the country's evolution. Sarmiento's dynamic, impetuous nature has often been commented upon. ${ }^{19}$ It is clear too from his work that Sarmiento wrote in the shadow of European Romanticism, ${ }^{20}$ and was obviously sensitive to its penchant for the exotic, for the satanic, and for Nature, especially in its wilder moods. Another side of the Romantic Movement urged for some sort of primitive innocence and Sarmiento includes some passing references to the purity of lifestyle amid the freedom of the pampas (pp. 44-5). But these, one feels, are literary evo- 
cations which are soon dispelled when Sarmiento concentrates upon the portrayal of reality.

The gauchos are described with outright condemnation, their qualities of bravery and nobility held in little esteem; their skills acknowledged but subtly undermined by repeated unfavourable comparisons with the productive efforts of a European work force. There may be an element of nostalgia in the telling of the triumph of the gauchos over nature, but the proposal remains clear that this is a lower stage of development, useless, purposeless, and one which must be overcome. Sarmiento's deep commitment is to reason and to intelligence, faculties which as he points out are not developed in the struggle against nature, where courage and cunning suffice. He writes: 'la vida en el campo, pues, ha desenvuelto en el gaucho las facultades físicas, sin ninguna de las de la inteligencia' (p. 47).

This does not imply that Sarmiento was insensitive to the aesthetic potentialities of Barbarism and, indeed, the pages describing the four types of gauchos are among the best that he has ever written. But aesthetic achievement ought not to be confused with ideological commitment, and if there is an undeniable feeling of pride and even admiration for the sheer skill and daring of the 'rastreador', the 'baquiano', the 'gaucho malo', and the 'gaucho cantor', these qualities are limited to the level of instinct, still an animal characteristic and one which rates well below those evinced by education and economic ambition. It is clear, therefore, that Sarmiento devotes himself to a lengthy and passionate exposition of Barbarism not in any Romantic spirit of literary evasion, but with the strong didactic purpose of showing its perils and deficiencies. He writes to condemn.

The unequal structural balance in the treatment of 'civilización' and 'barbarie' is caused by a difference in attitude towards the opposing concepts, for Facundo is not a manichean exposition in which the forces of evil and of good are left to struggle on equal terms, but a highly charged polemical work whose main object it is to lay bare the shortcomings of what it regards as Barbarism. The desirability of civilization is axiomatic to the conception of the work and understood as such by its reading public. It therefore needs neither proof nor description.

The abstract concepts of Civilization and Barbarism are expressed in human form in the portrayal of the two military leaders who in successive battles ${ }^{21}$ stood pitched against each other in command of their respective forces. They are, of course, Facundo Quiroga, the caudillo whose name serves as title to the work, and General Paz, the European-type military leader to whom the work's final words are almost ecstatically dedicated. In line with what has been stated hitherto, the portrayals are unequal in struc- 
ture, pursuing different aims. They vary not only in length, but in artistic achievement, thus bringing to mind an inescapable comparison with the portrayal of Satan and of God in Milton's Paradise Lost. There is no doubt that here the Devil is aesthetically the more attractive figure, yet there is no suggestion that in the ideological frame of reference of the poem he should be considered superior to God. Similarly Facundo is a more impressive, better drawn character, but this does not place him conceptually above General Paz.

In the portrayal of Facundo lies the strength of the work. Sarmiento proceeds in stages to damn the character in the reader's mind before giving any account of his public actions. Facundo is introduced in Chapter V, and the first glimpse of him is that of a young man fleeing from justice after a knifefight, something not uncommon among the gauchos, as the author hastily points out. The scene immediately following shows him being pursued by a tiger. The confrontation is described with heightened dramatic tension: whilst emphasizing the barbarism of the countryside, the author seems to revel in the atmosphere of bloodthirstiness, danger, and terror and in the power of the irresistible forces which he recreates:

el tigre marchaba a paso precipitado, oliendo el suelo y bramando con más frecuencia a medida que sentía la proximidad de su presa. Pasa delante del punto en que ésta se había separado del camino y pierde el rastro; el tigre se enfurece, remolinea, hasta que divisa la montura, que desgarra de un manotón, esparciendo en el aire sus prendas. Más irritado aún con este chasco, vuelve a buscar el rastro, encuentra al fin la dirección en que va, levantando la vista, divisa a su presa haciendo con el peso balancearse el algarrobillo, cual la frágil caña cuando las aves se posan en sus puntas.

Desde entonces ya no bramó el tigre; acercábase a saltos, y en un abrir y cerrar de ojos sus enormes manos estaban apoyándose a dos varas del suelo sobre el delgado tronco, al que comunicaban un temblor convulsivo que iba a obrar sobre los nervios del mal seguro gaucho. Intentó la fiera dar un salto impotente; dio vuelta en torno del árbol midiendo su altura con ojos enrojecidos por la sed de sangre, y a fin, bramando de cólera se acostó en el suelo, la boca entreabierta y reseca. Esta escena horrible duraba y dos horas nortales; la postura violenta del gaucho y la fascinación aterrante que ejercía sobre él la mirada sanguinaria, inmóvil, del tigre, del que por una fuerza invencible de atracción no podía apartar los ojos, habían empezado a debilitar sus fuerzas, y ya veía próximo el momento en que su cuerpo extenuado iba a caer en su ancha boca, cuando el rumor lejano de galope de caballos le dio esperanza de salvación. (pp. 92-3)

Yet in spite of the lyricism of this passage, the point made ultimately is that Nature, with its tigers, is wild and dangerous. And, as if by way of an afterthought, Sarmiento drily remarks 'también a él 
le llamaron Tigre de los Llanos, y no le sentaba mal esta denominación, a fe' (p.93), thus equating Facundo with the wild jungle beast. Once Facundo's bestiality is imprinted upon the reader's mind, Sarmiento proceeds to give a physical description of him. What follows is a portrayal in which the racialist bias of the author is manifest by his choice of features, emphasizing the dark traits of Facundo, and drawing repeated attention to his exceptional hairiness.

Facundo, pues, era de estatura baja y fornida; sus anchas espaldas sostenían sobre un cuello corto una cabeza bien formada, cubierta de pelo espesísimo, negro y ensortijado. Su cara, un poco ovalada, estaba hundida en medio de un bosque de pelo, a que correspondía una barba igualmente espesa, igualmente crespa y negra, que subía hasta los juanetes, bastante pronunciados, para descubrir una voluntad firme y tenaz.

Sus ojos negros, llenos de fuego y sombreados por pobladas cejas, causaban una sensación involuntaria de terror en aquellos sobre quienes alguna vez llegaban a fijarse. (p. 94)

The obvious implication of this ape-like depiction does not stop at the character's low evolutionary development, but, as Sarmiento suggests, and in accordance with the then current vogue of physiognomy, a science attributing a moral or psychological significance to physical characteristics, the description reveals a violent, indomitable inner nature. ${ }^{22}$ This implication is supported by the subsequent account of Facundo's wild aggressive behaviour as a youngster, not only in school, at work, or wherever he went, but even towards his father, whom he once struck in anger. Gradually, the private demon gives way to the public monster. Facundo the caudillo is shown to reign by dint of his superior force, in obeisance to the law of the jungle. Sarmiento dwells upon the horror of his regime: the atrocities committed are endlessly listed, the ruthlessness and savagery of his ways described in bloodcurdling details and his cynical treachery, his depravity and corruption are exposed. But perhaps his most heinous crime, according to the tenets of the work, was 'su encono contra la gente decente, contra la ciudad' (p. 115), i.e. his attack upon the last remnants of civilization. This being something outside his reach, he sets out to destroy it. In his work Muerte y resurrección de Facundo, ${ }^{23}$ Noé Jitrik claims that there is a second image of the caudillo in which he is endowed with some of the attributes of civilization, such as political acumen, human insight and a deep understanding of the historic moment. It is here suggested that the basis of the argument rests upon fragmentary readings taken out of the general context of the work which disregards the overall condemnatory attitude displayed towards the tyrant. 
Jitrik divides the presentation of Facundo into two basic impressions: the first, barbaric, cruel, indomitable, no different, in fact, from the one pointed out above, yet according to Jitrik this first impression gives way later on to that of a shrewd, calculating politician, one who is able to adopt to new circumstances, to govern with intelligence and who understands that great role that the Interior will be called upon to play in the political reorganization of his country. To support his argument Jitrik quotes in all seven short extracts taken from the first seven pages of Chapter VIII and the first eight pages of Chapter XIII; thus, he is clearly isolating two brief sections from a long work. He alleges that when Facundo was asked by the Buenos Aires Government to assume command of certain provinces, he became a changed man. The basis of this assertion is that Facundo responded readily to the rational request of the Buenos Aires Government much is made of this; that he did not commit any notable acts of violence at that particular time, probably in response to the changed conditions in the political climate (although this could only have been a short lived respite, for Facundo is soon shown to have reverted to his old barbarous ways), and lastly, that he was instrumental in carrying out Rivadavia's plan of unification. ${ }^{24}$ When in Buenos Aires, Facundo is said to have been responsive to the civilizing influence surrounding him. ${ }^{25}$

None of this can be disputed other than the significance attached to it. Jitrik's analysis, which is painstaking and percipient, fails to convince as to its conclusion that a revised portrayal of Facundo imposes itself upon the reader's mind. The positive remarks that Sarmiento makes about Facundo do not constitute a sufficiently strong basis to support all the allegations heaped upon it. They may indeed invite the reader to seek elsewhere for an historically more accurate account of Facundo, but in themselves they are far too weak to counteract the overwhelmingly damning impression of Sarmiento's literary portrayal.

What needs to be pointed out is that if Sarmiento does momentarily soften his attitude towards Facundo, he does so in the measure in which Facundo has adopted the values of civilization, i.e. responded to a rational plan, succumbed to the influence of Buenos Aires, insisted upon his son's education at the best city schools. It is significant, moreover, that Sarmiento does not dwell upon the later Facundo. The few acts of humanity that Sarmiento attributes to Facundo are normally presented as exceptions. He writes, for example: 'hay una circunstancia curiosa (1823) que no debo omitir porque hace honor a Quiroga: en esta noche negra que vamos a atravesar no debe perderse la más débil lucecilla' (p. 112). Other positive remarks are normally accompanied by the explanation that although 
Facundo was working in the interests of Unitarian policies, he did so without knowledge of what he was doing:

Así, la Providencia realiza las grandes cosas por medios insignificantes e inapercibibles y la unidad bárbara de la República va a iniciarse a causa de que un gaucho malo ha andado de provincia en provincia levantando tapias y dando puñaladas. (p. 135)

Thus, whilst it is true that Sarmiento makes some remarks that are not wholly consistent with the blackness of the picture, what is important is that any point conceded in favour of Facundo is immediately dispelled by a subsequent accusation of barbarity. The point bears emphasizing once again that no figure of a 'civilized Facundo' emerges from an objective reading of the text. It was important to refute it, because it seeks to deny the basic premise of Facundo which is that the infamous caudillo is the embodiment of barbarism and the epitome of that which must be destroyed. In his nationalistic fervour Jitrik has magnified a few scattered remarks and with complete disregard for the total image invented a mythical ancestor who would provide some measure of cultural backing to an attempt to vindicate the darkened image of the Interior. But the truth remains that a pro-Federalist image of the Interior is almost totally absent from the cultural literature of the middle of the century. ${ }^{26}$ Sarmiento does not limit himself to expose Barbarism for its evil; he attacks it further by subtly undermining the basis of the gaucho ethos, i.e. the glorification of valour, strength, intrepid horsemanship and showy bravado. The strongest blow that Sarmiento metes out to Facundo is that which is levelled at his most susceptible point, concerning his bravery and his qualities as a combatant and as a leader. In a page in which he pitches the tactics of the opposing leaders face to face, Sarmiento formulates a synthesis of his views and values from which the caudillo emerges greatly discredited and the Europeanized General triumphant:

Facundo, ignorante, bárbaro, que ha llevado por largos años una vida errante que sólo alumbran de vez en cuando los reflejos siniestros del puñal que gira en torno suyo; valiente hasta la temeridad, dotado de fuerzas hercúleas, gaucho de a caballo como el primero, dominándolo todo por la violencia y el terror, no conoce más poder que el de la fuerza bruta, no tiene fe sino en el caballo; todo lo espera del valor, de la lanza, del empuje terrible de sus cargas de caballería. ¿Dónde encontraréis, en la República Argentina, un tipo más acabado del ideal del gaucho malo? ¿Creéis que es torpeza dejar en la ciudad su infantería y artillería? No; es instinto, es gala de gaucho; la infantería deshonraría el tríunfo cuyos laureles debe coger desde a caballo. (p. 160) 
In this extract Sarmiento discredits the basic qualities of the gaucho ethos, effectively equating bravery with foolhardiness and showing manifest disapproval for the rule of force. Moreover, there is no sympathy or nostalgic understanding for the gaucho's traditional love of horsemanship, but merely disdain for his empty vanity. Facundo is here equated with the worst among the gauchos, and there is nothing but contempt and ridicule for his poor tactics as a guerrilla fighter. It is difficult to reconcile the above passage with Diez-Echarri's views when he states that 'Sarmiento simpatiza con él. Simpatiza instintivamente con todo lo que tiene el gaucho de arrojo, de violencia, de tenacidad. Si abomina de su conducta, es en nombre de principios políticos...' Once more, this critic seems to have fallen into the trap of believing that Sarmiento necessarily must sympathize with that which he describes best. ${ }^{27}$

If Facundo is the embodiment of Barbarism, his counterpart on the battlefield, General Paz, is the embodiment of Civilization. In line with what has been said about the unequal role of the opposing concepts, the portrayal of Paz, which follows and stands in direct contrast to the Caudillo's, is appreciably more succinct and his superiority is soon established. About him, the author writes as follows:

Paz es, por el contrario, el hijo legítimo de la ciudad, el representante más cumplido del poder de los pueblos civilizados. Lavalle, Madrid y tantos otros son argentinos, siempre soldados de caballería, brillantes como Murat, si se quiere; pero el instinto gaucho se abre paso por entre la coraza y las charreteras. Paz es militar a la europea: no cree en el valor solo, si no se subordina a la táctica, a la estrategia y la disciplina; apenas sabe andar a caballo; es, además, manco y no puede mantener una lanza. La ostentación de fuerzas numerosas le incomoda: pocos soldados, pero bien instruidos. Dejadle formar un ejército, esperad que os diga: 'Ya está en estado', y concededle que escoja el terreno en que ha de dar la batalla, y podéis fiarle entonces la suerte de la República. Es el espíritu guerrero de la Europa, hasta en el arma en que ha servido; es artillero, y, por tanto, matemático, científico, calculador. Una batalla es un problema que resolverá por ecuaciones hasta daros la incógnita, que es la victoria.

El general Paz no es un genio, como el artillero de Tolón, y me alegro de que no lo sea; la libertad pocas veces tiene mucho que agradecer a los genios. Es un militar hábil y un administrador honrado, que ha sabido conservar las tradiciones europeas y civiles, y que espera de la ciencia lo que otros aguardan de la fuerza brutal; es, en una palabra, el representante legítimo de las ciudades, de la civilización europea, que estamos amenazados de ver interrumpida en nuestra patria. (pp. 160-1)

The quotation is included in its entirety, because it constibutes a summary of Sarmiento's doctrine of faith: he praises Paz because he is the product 
of the city, because he is European in his ways, because he is scientific in his actions, moved by reason in accordance with carefully thought out plans and policies. He even praises him for not being a genius, which is a mark of Sarmiento's distrust of anything unmeasured or flamboyant. For Sarmiento the promise of the country's future resides with men like Paz, who fight in the spirit of enlightenment, freedom, and justice, and this mark of civilization is constantly equated with European values:

Los ejércitos de la República, que llevan la guerra a todas partes para hacer efectivo aquel porvenir de luz y tornar en día la aurora que el escudo de armas anuncia, visten azul oscuro y con cabos diversos: visten a la europea. ${ }^{28}$

$\mathrm{Paz}$, however, is not the only antonym to the indomitable caudillo from the Interior. There is yet another figure who shares the qualities of coldblooded reasoning and disciplined submission to planned stratagems, and this, as incisively pointed out by Jitrik, is Rosas. ${ }^{29}$ Like Paz, he too is the product of the cosmopolitan city of Buenos Aires, of its rational attitude and culture: 'espíritu calculador, que hace el mal sin pasión y organiza lentamente el despotismo con toda la inteligencia de un Maquiavelo' (p. 18). The relationship could be set out as follows:

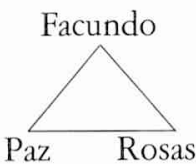

However, the temptation of using this triangular pattern for a syllogistical argument, implying that Sarmiento somehow equated Rosas with Paz, should be resisted, for in no way is this borne out by the general or complete presentation of the two figures. ${ }^{30}$

Rosas is the most hated of Sarmiento's enemies, the viper, the monster, the embodiment of evil and the final aberration of what a system of Facundos can create. There is, however, as pointed out above, an undeniable element of 'civilization' in the cool, analytical methods which he deploys to impose his rule of terror. Moreover, it is thanks to the extremity of his atrocities, and to the systematic annihilation of all opposition, that the pacification of the country as a whole was achieved. Is this Barbarism or Civilization? If these are understood not as static opposites but as progressive stages, then it becomes clear that Rosas represents the final outburst of energy of an obsolete system before it annihilates itself by paving the way for its successors. Thus in Rosas both Barbarism and Civilization are combined, but they are not fused conceptually, their original meaning remaining clearly defined. 
The portrayal of Rosas, like that of Facundo, has often been open to hasty interpretation. Thus, writing in La Nación in April 1896, Unamuno says about Sarmiento:

Era un formidable unitarista y un europeizante de cabeza, aunque profundamente argentino y criollo, y diría que hasta gaucho de corazón - y desde luego mucho más ibérico de lo que él creía ser.

The Spanish thinker adds:

Sin embargo, leyendo atentamente su Facundo se percibe cuán de veras admiraba a Rosas y como, aunque a su pesar, sentía que aquéllo que llamó barbarie contenía la sustancia de una civilización. ${ }^{31}$

In answer, therefore, to Unamuno's statement about the admiration that Sarmiento may have felt for the tyrant, it should be pointed out that Sarmiento, who saw things always in a relationship of cause and effect, hated in Rosas, as in everything else, the Barbarism which was his cause, but was thankful for his genius which would precipitate the desired effect. Sarmiento may have been drawn by the powerful, titanic figure, yet he manifestly did not admire Rosas, if by this word there is understood a sense of moral approval. Imbued with the optimism that saw History as bent on an inevitable forward march, he was confident that even Rosas's abominable rule would eventually have its beneficial effect upon the country. The examples that he quotes in this sense show that all the advantages to be gained from this dreaded phase of Argentine history would be achieved as its indirect consequence, attributable to the tyrant in spite of him. Thus, Rosas is seen as an historical necessity in order to tame the country to a point of total submission, enabling the subsequent imposition of a strong centralized government, this being an essential prerequisite for the Unitarian policy of liberal cosmopolitanism. The fact that in Sarmiento the policy is to be implemented for the general good of the whole nation, acquiring a national, as opposed to a purely littoral dimension, does not minimize the Europeanizing flavour of his aims. A synthesis of the approved, predicted achievements of the Rosas regime, reveals the absolute and unidirectional dedication of Sarmiento's Facundo towards bringing the country into closer contact with Europe. In a passage in which Rosas's americanismo stands opposed to the author's own europeis$m o$, the latter states that he is proud of having joined forces with Europe against the national tyrant, if by so doing he acted in the cause of Europeanization (p. 265). He further rejoices in that one of the backlashing consequences of the curtailment of the civil rights of the criollos, 
was the enhancement of the position and influence of foreigners, and is heartened by the fact that all those young men who were exiled for opposing the tyrant were forced to travel abroad and come into contact with other more civilizing ideas (p. 275).

The ultimate objective in advocating Europeanization, and that with which this study is most intimately concerned, lies in the outspoken plea for European immigration to be found in the concluding pages. This, it will be noted, is not advocated simply in order to provide the necessary manpower for the development of the economy, but is hailed as a positive influence in the ethnic composition of the country. Up to this point, most of what has been said about Facundo shows that it stands in the same ideological line as El Matadero and Amalia, in that it is a work imbued with a doctrine in which Europe stands for Civilization and is the model to be emulated, thus implying tacitly the superiority of Europeans over the native born (with the understood exception of those criollos whose americanismo was merely a geographical characteristic but who, by virtue of their ancestry and education, belonged in cultural terms to the Old World).

But Facundo does not stop at this implication when, in its concluding pages, it states clearly and overtly that it is in favour of attracting large-scale white immigration at the expense of the existing criollo population. So little was Sarmiento 'muy gaucho de corazón' in 1845, that one of the results which his already mentioned optimism caused him to see in the Rosas's reign of terror and bloodshed, was the gradual extinction of the native population. ${ }^{32}$ This is recorded without a word of regret - on the contrary, a certain rueful satisfaction can easily be detected in the final prediction:

¿Los gauchos, la plebe y los compadritos lo elevaron? Pues él los extinguirá: sus ejércitos los devorarán. Hoy no hay lechero, sirviente, panadero, peón, gañán ni cuidador de ganado que no sea alemán, inglés, vasco, italiano, español, porque es tal el consumo de hombres que ha hecho en diez años; tanta carne humana necesita el americanismo, que al cabo, la población americana se agota, y va toda a enregimentarse en los cuadros que la metralla ralea desde que el sol sale hasta que anochece. (p. 274)

And, a little further on, Sarmiento writes:

¿Degüella, castra, descuartiza a sus enemigos, para acabar de un solo golpe y con una batalla, la guerra? Pues bien; ha dado ya veinte batallas, ha muerto veinte mil hombres, ha cubierto de sangre y de crímenes espantosos toda la República; ha despoblado la campaña y la ciudad para engrosar sus sicarios, y al fin de diez años de triunfos su posición precaria es la misma. Si sus ejércitos no 
toman a Montevideo, sucumbe; si la toman, quédale el general Paz con ejércitos frescos; quédale el Paraguay virgen; quédale el Imperio del Brasil, quédale Chile y Bolivia, que han de estallar, al fin; quédale la Europa que lo ha de enfrenar; quédanle, por último diez años de guerra de despoblación y pobreza para al corazón de la América. Bolivia se asociará, quiera que no, a este movimiento, y Santa Fe, Córdoba, la República, o sucumbir; no hay medio. ¿Triunfará? Pero sus adictos habrán perecido, y otra población y otros hombres reemplazarán el vacío que ellos dejen. Volverán los emigrados a cosechar los frutos de su triunfo. (p. 275)

It is this final triumphant note of faith in the country's progress towards Europeanization as synonymous with its march towards Civilization, which must be borne in mind in any ultimate evaluation of the ideological content of the work's basic concept of Civilización y Barbarie. It is true that the clearly defined division of Civilization and Barbarism suffers at time from a number of internal contradictions. The question to be posed in this connection is whether these inconsistencies with the overall polarization of the work denote an essential ambiguity in its conceptual framework - a rift between the ideological framework adopted, and the reality observedas suggested by Jitrik, or whether they are subtleties which point to Sarmiento's apprehension of the complexity of the times which qualify the first categorical divisions without however challenging their assumptions. The basic antithesis between Civilization and Barbarism is expressed in several other parallel terms. Thus, Europe is counterbalanced by America, urban life by rural life, the Littoral Provinces by the Interior. Similarly, order has its counterpart in anarchy, instinct in reason, and so on. The basic polarizations, however, branch out in a dichotomic pattern. Thus the distinction is made in Europe between the traditional Hispanic culture and the progressive culture of France and England. In Argentina this division is reflected in the development of its cities, with Córdoba retaining the Hispanic influence, and Buenos Aires becoming the seat of progress, following the most advanced ideas from Europe. Yet this hierarchy still obeys the original division; either city is placed above the rude countryside in a scale of values. On the plains one may find an exceptional display of pure devotion in a patriarchal household, such as Sarmiento recounts he once experienced in Sierra de San Luis (pp. 44-5), but the norm is represented by the overall lawlessness and the scenes of brutality and tyranny practised by the Caudillo. Clearly there is a hierarchical distinction here, yet both concepts seem inferior to the cultured life of the city: the first because of the precariousness of its existence, the second because of its utter barbarity. Yet what happens to this argument of a hierarchical scale when the city falls prey to the forces of barbarism, such as 
when La Rioja becomes a ghost town, with only a handful of families left and no seats of learning or signs of culture, or when Buenos Aires seems to lead the country in its despotism, indeed in all the manifestations of barbarism? The argument still holds, for this is not a weakening of the initial polarization, or an assertion of the superior merit of the Interior. It is a dramatic warning against the destructiveness of Barbarism if left unchecked.

If there is any ambiguity in Facundo, it arises from a lack of fusion between certain descriptive passages and other rhetorical ones, or, in other words, a failure to synthesize the ideological message with the aesthetic content. But taken in its entirety, there is no ideological ambiguity in Facundo: it remains an unequivocal testimony against the times it describes, which it condemns as barbarous, and whose forces it wishes to suppress and replace by those that it terms 'civilization'. Of these, immigration is an integral part, and one which is advocated both implicitly and explicitly throughout the pages of Facundo with a conviction and fervour which remains unparalleled in the literature written after immigration had actually taken place. 


\section{II · "PEREGRINACIÓN DE LUZ DEL DÍA"}

The two main works examined in the Pre-Immigration section are both written by prominent political theoreticians, men who throughout their lives were intimately connected with the question of Immigration. Indeed it was Alberdi, the author of the work to be analyzed in the present chapter, who first coined the phrase 'gobernar es poblar', which has been loosely translated as 'to foment settlement is the essence of government'. Alberdi expounded his ideas in favour of massive immigration in his famous Bases, ${ }^{2}$ the most important treatise to have influenced the writing of the Argentine Constitution of 1853.

Although, as will be shown, Sarmiento and Alberdi expressed their ideas in quite different ways, to the extent that a bitter personal antagonism developed between them, ${ }^{3}$ there is a basic agreement to be found in the policies which they advocated. ${ }^{4}$ Both thought of Europe as vastly superior to America, and both wished to Europeanize their country by means of massive immigration, preferably from the more advanced industrialized countries of the north. Sarmiento, in Facundo, placed a strong part of his argument in his exposition of the Barbarism of America and its manifestations in the indigenous population; Alberdi, in Peregrinación de Luz del Dia, concentrates instead on highlighting the positive qualities of Europeans, particularly of the Anglo-Saxons, and shows little interest for the native population. He adopts a wholly Europocentric stance and in doing this, he follows in the tradition which had been prevalent throughout the period of European expansion, during the Colonial era, and which, as his work demonstrates, continued even after Independence. One can say that if, as is commonly held, Independence did not bring any radical change in the system of government, ${ }^{5}$ only in the nationality of its rulers, neither did it bring any radical changes in the cultural system of the new nations. Argentina, for one, continued to look to Europe for guidance and intellectual leadership.

Peregrinación de Luz del Dia is an important work, firstly because it illustrates the preeminence of Europe in the national consciousness and secondly, because it expresses the principal ideas which have helped to shape the present policies of Argentina. These are the two main aspects of the work which the following pages will examine. But first a few words about 
the literary merit of Peregrinacion. Opinions on this most unusual work differ greatly. Modern critics tend either to dismiss it ${ }^{6}$ or to make disparaging remarks about its style. Anderson Imbert, writing in Spanish American Literature $^{7}$, comments that:

This allegorical novel, showing signs of improvisation and defects of a writer not cultivated as such but containing a few aphoristic phrases of great strength, can amuse one who is interested in the clues and can recognize the allusions to the political scene of those days; as pure literature it will put one to sleep. (p. 224)

Crawford, in his A Century of Latin American Thought, ${ }^{8}$ says that:

When Alberdi tries his own hand at imaginative literature, the candid critic must admit that the results are sad. There exists a curious performance called 'The Light of Day in America', in which a lady with that most allegorical name, disgusted with the lack of truth in Europe, sets out to seek it in the Western Hemisphere. She has a variety of conversations and adventures, but, of course, does not find truth, and at last hires a hall to give people a piece of her mind. This is what the author has been uncomfortably waiting for; he can write speeches, but not novels. (p. 20)

Yet Saenz Hayes thinks highly of it: 'Luz del Día es un libro de superlativo pesimismo emparentado con las más genuinas expresiones de abatimiento moral... La tercera y última parte de Luz del Día es un feliz y fidelísimo compendio del ideario alberdiano'. He quotes Manuel Estrada's praising comments:

Todos hemos leído la novela - dice Estrada - y todos hemos admirado su colorido, su movimiento, su agudeza, la profundidad de ciertas sentencias, cuya paternidad no desdeñaría Séneca, el aticismo y la mordacidad de sus epigramas, su sátira tremenda y punzante contra la prensa periódica, los mil reflejos de alto ingenio con que deslumbra al lector... así este libro es a la vez bello, profundo, animoso. ${ }^{10}$

Ricardo Rojas is the most informative of Alberdi's critics. While he decries the many solecisms and inelegancies which mar the work, he praises its scope and originality. It is interesting to note that Rojas attributes Alberdi's poor style to the fact that he disliked the Spanish language and was not well read in it. He quotes him as saying: 'no frecuenté mucho los autores españoles; no tanto por las preocupaciones antiespañolas, producidas y mantenidas por la guerra de nuestra independencia, como por la direción filosófica de mis estudios'. ${ }^{11}$

Peregrinación de Luz del Dia ${ }^{12}$ was written by Alberdi between 1870 and 1871 , in London. It is his best known novel, if indeed it can be so called, for although as the subtitle indicates, it relates the journey and adventures of 
Luz del Día in the New World, the fictional content of the work constitutes no more than the barest of skeletons, on which Alberdi imposes an edifice of ideas in which philosophical cynicism and political conviction coexist in unplanned confusion. Its hybrid genre is neatly summarized by the author himself in the opening page, in which he declares:

Es casi una historia por lo verosímil, es casi un libro de filosofía moral por lo conceptuoso, es casi un libro de política y de mundo por sus máximas y observaciones. Pero seguramente no es más que un cuento fantástico, aunque menos fantástico que los de Hoffmann. (p. 31)

The minimal plot is straightforward: Truth, ${ }^{13}$ defeated in Europe by her counterpart Falsehood, changes her name to Luz del Día, dons female clothing and sets off for the New World, in search of a less corrupt society. The story evolves divided into three parts: in the first, Luz meets certain well-known characters from French and Spanish literature, prototypes of moral deficiencies; disillusioned by them she seeks, in the second part, the epic heroes of the older Spanish literature but is no more satisfied by their conduct than she had been before. This brings her in Part Three to a decision to leave South America, but first she holds a conference on the true meaning of freedom and the best means of achieving it. Her ideas are in fact a synthesis of Alberdi's political programme as expressed twenty years earlier in his Bases.

The author of Peregrinación speaks with two different voices. On the one hand he adopts a cynical, pessimistic air and, in a highly satirical allegory, gives vent to the bitterness and disillusion that he felt because Argentina had not lived up to the rather unrealistic expectations of his Bases. For in the Bases, as in Peregrinacion, Alberdi placed himself firmly in the cultural context of Europe and of the U.S.A., transplanting their ideas to Argentina without due regard to the South American reality itself, i.e. its social and political underdevelopment. As Max Rhode says, he failed to take into account the existence of fraud, licentiousness and corruption. ${ }^{14}$ On the other hand, Alberdi expounds once more his liberal programme, and adopting a positive and constructive stance, he analyzes his country's needs and puts forward the principal ideas of the Bases. He declares that militarism is a retrograde form of government, a force which leads to absolutism and tyranny, whereas what the country needs is liberty in order to achieve its economic potential. The only means for this, according to Alberdi, would be to import the right kind of immigration. There is, however, one unifying factor that links even the most disparate aspects of Peregrinacion and that is the Europocentric stance from which it has been 
conceived. This does not imply that Alberdi admires Europe without qualification, but merely that he measures everything against a European yardstick, ignoring all other values or criteria.

The experience of Truth in South America is accompanied by a general loss of illusion which began at the outset when to her innocent surprise she realizes that the New World is merely a degraded version of the Old, for not only does she encounter the same characters from whom she had originally tried to get away, but she finds that their ills have, in fact, become aggravated in the new continent. Thus the same Tartufo, who in Europe had been the prototype of bigotry and hypocrisy, set by Molière in a family context to show his deficiencies as inner moral failings, now operates in America in a wider political arena. The same is the case with the other characters, Basilio and Gil Blas (p. 235) ${ }^{15}$ Perhaps even more telling is the change undergone by Don Quixote, who in America fights not against windmills or giants, but against false liberals, whose bad government he opposes, yet whose cattle he shrewdly appropriates.

The difference in behaviour between Europe and America is illustrated in the following judgement of Don Quixote: 'Sin dejar de ser el mismo loco, en América se ha vuelto un loco pillo, un loco especulador' (p. 154). The idea that Europeans degenerate through living in the New World finds an antecedent in the writings of Cornelius de Pauw, a Dutch polemicist of note in his time, now much discredited. ${ }^{16}$ His ideas on the noxious effect of life in America became the point of departure of a much wider, influential debate about the relative merits of the population in the two continents. ${ }^{17}$ The nucleus of his thought is illustrated by the following quotation:

The Europeans who pass into America degenerate, as do the animals; a proof that the climate is unfavourable to the improvement of either man or animal. The Creoles, descending from Europeans and born in America, though educated in the universities of Mexico, of Lima and College of Santa Fe, have never produced a single book. The degradation of humanity must be imputed to the vitiated qualities of the air stagnated in their immense forests, and corrupted by noxious vapours from standing waters and uncultivated grounds. ${ }^{18}$

Analogy between the two continents is taken further in Peregrinación when Tartufo says:

Lo cierto es que América, con sus defectos y cualidades, no es más que un reflejo de la Europa de más atrás, y nada contiene de bueno y malo, que no sea europeo de índole y carácter. (p. 50) 
The character thus voices a Europocentric view of America which predominated until the end of the nineteenth century. The idea of America as a more recent and still immature continent was first systematized in a coherent and scientific way by the French naturalist Buffon, who based his argument on the observation that the fauna in America was generally smaller than in Europe, either in the sense that the existing species in America were smaller or that those animals which had been transplanted to the New Continent did not there grow to their accustomed size.

A. Gerbi, writing on the dispute that followed from this theory, and which developed over centuries, observes an uninterrupted flow of the theory of the inferiority of America which extends from Buffon to De Pauw to Hegel. It is here suggested that Alberdi's name could be added to this list in that he, too, in Peregrinación, voices opinions on the 'degenerating' effect of America upon Europeans. More significant may be the observation that Alberdi, an American, with intimate knowledge of his own country should be so imbued in European thought as not to question but be prepared to perpetuate these myths about his continent. For behind the irony of his tone, one can detect a fundamental agreement with the above ideas. Gerbi makes the following comment on Buffon's thesis which can equally be applied indirectly to the implications behind many of Alberdi's statements:

Juzgar inmadura o degenerada la fauna americana equivalía a proclamar madura y perfecta la del Viejo Mundo, apta para servir de canon y punto de referencia a cualquier otra fauna, de cualquier ángulo del globo. Con Buffon se afirma el europeocentrismo en la nueva ciencia de la naturaleza viva. ${ }^{19}$

Buffon at least examines American fauna before arriving at his conclusion; in a different context Sarmiento too chose to discredit the native American by concentrating upon his barbarism, but Alberdi, in the fictional aspect of Peregrinación, is concerned only with Europeans and with their reaction to the American reality. What can be said in this respect about the fictional setting of Peregrinacion is that it is significant not in what it includes, but in what it omits. The unseen part of the iceberg is the whole of the autochthonous American population. All the characters in Peregrinación stem recently from Europe, and these do not even represent real Europeans, men of flesh and blood such as might have arrived on American soil, but are imports twice removed, being merely familiar stock characters taken from works of French and Spanish literature.

The abstract mould, the satirical and allegorical tone of the narrative, are reminiscent of such eighteenth century writers as Voltaire, Montesquieu 
and Swift. ${ }^{20}$ There is, in fact, something slightly outdated about the stylistic framework of Peregrinacion which concerns its elitism and its fashionable pessimistic outlook on society. The work is elitist, for in dealing with the condition of Europeans in America, it restricts itself by the very fact of its concern with Europeans, to the higher sections of society, who were traditionally the preoccupation of the literature of the Enlightenment.

It furthermore conforms to this past period in that it adopts a lighthearted tone to express what is fundamentally a pessimistic outlook on humanity, with its final reminder that however degraded conditions have become in America, there is little to indicate that they would essentially be better elsewhere. ${ }^{21}$ Alberdi's cynicism can also be said to have found inspiration in the biting style of the nineteenth century Spanish satirist Larra, whose pseudonym 'Fígaro' he adopted as 'Figarillo' for his contribution to the satirical journal La Moda. ${ }^{22}$ Furthermore, and missing the dynamic of Determinism found in Facundo, Peregrinación stands against an ideological background which suggests a fixed, univocal concept of reality. Thus, Luz declares: 'la verdad es una, como la naturaleza' (p. 309).

This ideological 'fixity of meaning' is reflected in the language used by Alberdi, which is at all times clear, lucid, transparent, and totally uneventful. There are few adjectives, and those that are used conform unobtrusively to the noun they qualify, offering a wholly unequivocal exposition of the author's ideas. These, ultimately, do not concern themselves with philosophical statements about society, but relate to crucial contemporary questions of a political nature. Thus, the outer framework of Peregrinación is that of the eighteenth century satirical novel; its inner core is one of explicit political didacticism, propagating the merits of liberal laissez-faire policies. $^{23}$

Alberdi declares that the prerequisite for any advanced society is to ensure the conditions for a democratic government, which would guarantee freedom of speech, of association, of movement, as well as the personal freedom of education. But at the basis of Alberdi's political programme lies the bourgeois industrial ideal, since the ultimate purpose of freedom for Alberdi is the freedom to work in private enterprise and free from government interference. This would include the freedom to import immigrant labour. In fact, the key to the implementation of such a programme lies for Alberdi in immigration. But before discussing the more specific question of immigration, it is interesting to analyze the main arguments that Alberdi puts forwards. These can be examined in the speeches of Luz del Día, the author's mouthpiece. She says that Liberty is won 
neither in battle nor through glory, but is obtained through the reign of order. For only in a peaceful ordered society can trade and industry flourish, and it is the opportunity of joining onto the upward trend of economic well-being as experienced in Anglo-Saxon countries which constitutes the essential prerequisite for political freedom. The full impact of such a view may not strike the modern reader, but if one takes into account the exalted, indeed unassailable position of military patriotism in Latin America then as now, it becomes clear that by undermining the grandness of military glories, Alberdi was being almost iconoclastic. ${ }^{24}$ Against the worship of heroes and flags, Alberdi offers the view that Hispanic American freedom was won not by the heroic feats of Bolívar and San Martín, but as a consequence of the commercial poverty and general decadence of the Spanish metropolis, which could no longer supply the needs of its colonies. The glorification of war is seen as a means to prolong absolutism, discourage immigration and generally stand in the way of industrial development. Luz del Día declares:

La guerra no tiene efecto más seguro y positivo en Sud-América que el de perpetuar la incapacidad del pueblo para el gobierno de sí mismo porque ella interrumpe el trabajo de su educación y de su cultura política, espantando y alejando del país a los inmigrados sanos y cultos que son los únicos que educan en la libertad; y atrayendo en su lugar a las inmigraciones de aventureros que no saben sino alquilar su brazo para matar por la espada, su único utensilio industrial ... (pp. 261-2)

Thus Alberdi decries the more traditional spiritually biased glorification of the exploits of the sword with its resonance of valour and honour and comes down strongly in favour of a blatantly materialistic ethos in which production and technocracy are the most highly valued assets. It will be observed throughout this study that the concept of Immigration is inseparable from that of productivity. The variant will reside, not in the actual portrayal of immigration, but in the light in which this portrayal is made. For Alberdi, work is not only a positive quality, but the overriding criterion on which immigration should be encouraged. He is in fact most daring in his commendation of it on a purely materialistic basis; he does not find it necessary to speak about the spiritually uplifting quality of work, but says, with singular directness, 'el trabajo es dinero, y el dinero es libertad, porque el dinero es poder y es fuerza' (p. 278). This unashamed linking of money with freedom, power and strength, attributes which are traditionally seen in Hispanic culture clothed in a more spiritual garb, is a rare, almost unique experience in Argentine letters. The sound alone of 
the word dinero, whose accompanying adjective in Spanish is so often el vil dinero, and which is here repeated three times, as if with incantatory adulation, is a phenomenon that will not recur with such explicit fervour or directness.

Alberdi places all his faith in the future development of the country upon the effect of immigration. He believes that the right type of immigration would set in motion a whole chain of beneficial events which he envisages as follows: Immigration would constitute a useful work force; this in turn would bring riches to the country and attract greater capital investment. At the same time, the way of life set by immigration would influence the local population both by its example and by miscegenation, and the general outcome of all this would be to bring political maturity, i.e. civilization, to Argentina. The ideas on this subject set put in the Bases are repeated in Peregrinación without any perceptible difference in either the language or the treatment of the subject.

In the Bases, Alberdi wrotes:

La población es el fin y es el medio al mismo tiempo. Cada europeo que viene a nuestras playas nos trae más civilización en sus hábitos, que luego comunica a nuestros habitantes, que muchos libros de filosofía... La planta de la civilización no se propaga de semilla sino con extremada lentitud. Es como la viña, que prende y cunde de gajo. ${ }^{25}$

In Peregrinación the same faith in Immigration can be found. Thus,

Resolver el problema de la población es resolver el problema de la educación de Sud-América en la práctica del gobierno interior de sí mismo. No son dos problemas, sino uno solo. No hay dos soluciones para él, no hay más que una sola. (p. 263)

Not any immigration, however, is to be equally welcomed. Alberdi had qualified in his Bases the much quoted phrase 'gobernar es poblar', and repeats the warning, in the chapter entitled 'Casos en que poblar es asolar' (Part I, Chapter XV):

Aquí he oído - dice Luz del Día - que gobernar es poblar. El axioma puede ser verdadero en el sentido que poblar es desenvolver, agrandar, fortificar, enriquecer un país naciente, poblar es educar y civilizar un país nuevo, cuando se le puebla con inmigrantes laboriosos, honestos, inteligentes; es decir, educados.

Pero poblar es apestar, corromper, embrutecer, empobrecer el suelo más rico y más salubre, cuando se le puebla con inmigrantes de la Europa atrasada y corrompida. (p. 57) 
Further on, Luz develops the idea that just as only an industrious population can bring about political freedom, so will only an industrious population attract capital investment. The character declares:

¿Queréis traer capitales extranjeros a nuestro suelo americano? La mejor forma o vía para hacer esa importación es traer trabajadores extranjeros, obreros extranjeros, para que planten y aclimaten el árbol del trabajo en el suelo americano. Ése es el árbol del oro. (p. 264)

Two points of interest emerge from the above quotation. The first concerns the similarity in the language both as regards the declamatory tone of the rhetoric, and the use of roughly the same metaphors, such as árbol and planta in connection with the theme of Immigration as used here and in the earlier quotation from the Bases. The second relates to the word oro, which, in line with the previous usage of dinero, is not expressed as an evil, corrupting force, but as a desirable attainment.

Alberdi makes a sharp division between the comparative merits of AngloSaxon people and of Latins, showing a marked preference for the former. He bases his arguments regarding the superiority of the Anglo-Saxons on the importance of environmental factors and the influence of these in forming racial and cultural characteristics. Thus, expressing an Aristotelian belief in the nexus between climate and genio, Alberdi makes much of the distinction between cold lands and warm ones. He thinks that cold areas are more propitious to hard work and thus to material prosperity and its concomitant, political maturity and, as a consequence, produce a more valuable population. He favours the climatic conditions both in Europe as a source of population, and in his own country as the target for development. He writes about the first point:

Sud-América debe hacerse poblar de preferencia por la Europa del Norte, si aspira a ser libre y rica. Debe buscar su educación y desarrollo liberal en el trato saludable y fecundo de la Europa del frío. (pp. 273-4)

The part of Argentina to which immigration should be encouraged should be la tierra americana que corresponde por el clima a la tierra europea de los puritanos que plantaron y aclimataron la libertad y la industria en la "Nueva Inglaterra"' (pp. 58-9). The opposite is found in the warm regions which, according to Alberdi, are naturally fertile, and therefore attract and produce only a lazy population, being thus a breeding ground for absolutism or political tyranny. He says 'la América que da frutos sin trabajo y sin cultivo, será poblada por ociosos y por esclavos, explotados por otros ociosos usurpadores' (p. 59). The puritanical vein of these 
assertions reaches out into the cultural field, for Alberdi continues his distinction by offering the choice between 'la América de la poesía' and 'la América de la libertad'. The sets of opposites seem to him to be mutually exclusive, and the full extent of the disregard in which Alberdi held the former, can be felt from the ironical tone in which the choice is offered: "Si la América antes española prefiere ser la "América de la poesía" a ser la "América de la libertad" puéblese entonces con las inmigraciones de la Europa latina' (p. 269).

Strongly influenced by the racialist ideas of the times, Alberdi repeats the stereotyped generalizations usually made on this issue. Climate may be an important factor, and so may cultural heritage, but the deciding factor for him lies in the inherent make up of the people themselves. He argues that if the Indian races are weak and lazy, the Latin races have done little to improve them, for they themselves are rather too inclined to showy military exploits, verbosity, and grandiloquence. Alberdi duly acknowledges their 'spiritual' qualities and the warmth of their family life (p. 305), and agrees that they have some contribution to make to humanity, but he argues that their particular attributes are not the ones most needed by his country at that time. It is clear that for Alberdi the Anglo-Saxons and the Northern races stand at the top of the racial pyramid. They are the people who have reached the goals that he values most highly: political maturity and economic success. This, he argues, was not achieved by government decree but by the 'hard mettle' of the people themselves. The example of the U.S.A., who attracted the right kind of immigration, is that which Alberdi proposes for his own country:

¿Queréis traer a nuestro suelo la libertad inglesa? En lugar de traer sus leyes escritas, traed sus ingleses, su emigración, con sus costumbres y hábitos en que viven sus libertades, que no se producen ni revocan por golpes de Estado ni por revoluciones caligráficas. (p. 265)

It should be pointed out that Sarmiento, who at the time of writing Facundo was pleading simply for any white European immigration, revised his ideas and came late in life to agree with Alberdi on this. He felt that Europe was sending its human debris, illiterate peasants, who were unskilled and politically immature. Particularly after his journey through the U.S.A., he too came to admire the North Americans for much the same reasons as Alberdi. He ends his work on Conflicto y armonia de razas en América with the following words: 'alcancemos a los Estados Unidos como el mar al Océano. Seamos Estados Unidos'. ${ }^{26}$ Where Alberdi and Sarmiento did differ radically, was in their approach to education. For Sarmiento this con- 
sisted of setting up schools throughout the country, and putting an end to illiteracy. He had the Romantics' faith in the power of education. But for Alberdi this was merely a matter of 'instrucción por la letra', a technical ability of small importance on its own. He advocated 'educación por las cosas' as a wider process, one which would involve a person's complete outlook and way of life. ${ }^{27}$ It was not to be acquired in schools or universities, but in everyday existence, just by living next to the right sort of people, and copying their habits and acquiring their mentality. The best sort of people were, needless to add, the Anglo-Saxons: ${ }^{28}$

La libertad es una conducta, una educación, una dirección, una costumbre de vivir y conducirse. Vive arraigada en el hombre, no en el papel escrito, y la costumbre engendra la costumbre, como el hombre al hombre. La libertad vive, viaja y se propaga con el hombre libre, que al presente es el hombre del Norte frío como su temperamento, que es el de la libertad misma. (pp. 268-9)

The question of Immigration was so important to Alberdi that it is the one issue on which he makes exception of his belief in laissez-faire, or as he put it, in 'el poder de las cosas que rige el poder de los gobiernos' (p. 272), and talks of the need for a planned as opposed to a spontaneous immigration. The latter, he says, would only bring forth the undesirable Fígaros and Basilios, and perpetuate the stage of economic and political backwardness. It is this point that Alberdi's clear-cut positive political thinking becomes confused with his adopted pose of detached cynicism, and in his mistrust of government he fails to give specific advice on the course to be followed. The language used is strong indeed:

Si se pone ese inmenso elemento en las manos del gobierno, lejos éste de atraer la inmigración que enseña al pueblo a no necesitar de sus dictadores, traerá la chusma y basura de la emigración europea, por ser la que mejor le sirve para mantener al país ignorante y desnudo, en fuerza de esa ignorancia, del gobierno de sí mismo. (pp. 276-7)

The answer as to how and through whom immigration should be controlled, is not given, but a conjecture may be offered based on the fact that Alberdi has thought it worth while to write about it in fictional form. This seems to separate him from the involved politicians, and place him on a higher, more detached plane; that of the writer in his role as sage or of the leisured liberal gentleman, a member of disinterested élite group to whom a task such as the control of immigration might well be entrusted. The way in which Immigration is discussed shows that it is thought of as an abstract concept, a fixed entity, to be used and manipulated at will. It could be said that the artificial treatment of Immigration gives it the same 
fairytale quality that accompanied la Verdad in her ridiculous exploit as Luz del Día, or Tartufo, Basilio, or Fígaro in their allegorical antics. For la Inmigración, too, can be thought of as merely a two-dimensional character, whose complexity is confined to a stock-type division of Latins and Anglo-Saxons. It bears no relation to reality: immigrants, according to usual classifications, are defined as second- or third-class passengers ${ }^{29}$ arriving from Europe on transatlantic liners. Neither the handful of British in $\mathrm{Ar}$ gentina, nor those who are represented by the Fígaros and such of the story, would really come under that category. Apart from a consideration of desirability, there was no reason to suppose that an Anglo-Saxon immigration, in the true sense of the word, would feel attracted to Argentina when there existed other lands awaiting their arrival with which they had historical, cultural, and climatic ties. ${ }^{30}$ It is not, however, within the province of this thesis to embark upon a study of the soundness of Alberdi's ideas, but merely to point out that this most vital point of his work is treated by him in an over-idealized manner which betrays an arbitrary and somewhat superficial approach. He looks at the problem exclusively from the outside, from the point of view of the receiving country and without any human or even practical considerations for the immigrants themselves. In this he sets the pattern for the literature that will follow. It was a feature common to the two major works of this period that no specific individual immigrant characters were represented. Both Sarmiento and Alberdi thought about immigration in the abstract, as a commodity which they saw in terms of a work force and a breeding element and not as a conglomerate of individual human beings. In theory a massive white influx had to be beneficial, and it was advocated, always in conjunction with an overt materialistic ethos, with an enthusiastic fervour never to be encountered again.

This is the way in which Immigration was presented when it was still a proposed project. A study of the reaction to this theory put to practice will be the object of the following chapters. 

THE IMMIGRATION PERIOD: THE ANTI-IMMIGRANT NOVELS 



\section{I · BACKGROUND TO THE LITERARY SCENE}

The period in which the flow of immigration first acquired its true momentum, was that which began in 1880 with Roca's first Presidency. ${ }^{1}$ The number of immigrants increased from 210,300 in 1869, the year of the first official census, to 1,004,500 in 1895, the year of the second census. The figures are eloquent in themselves, but become even more impressive if seen in relation to the total population. The latter rose, in the period mentioned, by over 2,000,000 inhabitants, thus more than doubling the original number. ${ }^{2}$ It was an important time in Argentina's history, an era of great economic growth and unprecedented financial prosperity. Teeming activity in land production was matched by the bustle of an expanding capital, for Argentina was on the verge of becoming one of the fastest growing nations of the world.

The moment was ripe for a social concern to manifest itself in literature. Since its unification under the leadership of porteño federalism, the country, and its capital in particular, was undergoing vast changes which could not fail to preoccupy the members of its small but influential intellectual élite. The vertiginous expansion witnessed was not confined in its effect to the face of the land and changes were felt in the root of society, affecting its traditional balance. While the opposing forces of society had remained static, and consisted of an antithesis between a homogeneous ruling group and a voiceless majority, there seemed to be no real threat to the status quo, and it is not surprising to find the literature of belles lettres ${ }^{3}$ to have been largely a subjective exercise either of fanciful evasion or of autobiographical reminiscences of self indulgence in the established order. ${ }^{4}$ Once the transformational process of the Liberal Programme was under way, however, it became important to evolve a new attitude, and a literature developed which became acutely aware of the changing reality and sought to describe it mostly, it is true to say, in order to influence it.

Strong links united politics, economics and literature. In politics, justifications were sought in the paternalism of Comtian Positivism, for the rule by and in the interest of a small élite. ${ }^{5}$ Economic rules, guided by the principles of laissez-faire, in which market forces are ostensibly left free to operate, were so designed as to reinforce and perpetuate the hegemony of the 'fittest'. Similarly, the preoccupation in literature, with particular re- 
ference to the question of Immigration, can be seen to have been related to the direction of the development of the country, with a close interest shown in its effect upon the higher echelons of society. In short, the elitism which was at the root of nineteenth century liberal thought in Argentina, was reflected in the general conception of its literature, though here, as in other fields, this bias was disguised by the apparent objectivity of a cool, scientific approach.

The burst of energy in productivity which was noted above, spread to the literary field, too. The novel in particular found rich inspiration in the changes which were taking place and a veritable boom in fiction writing ensued. According to the painstaking research undertaken by Myron I. Lichtblau, the volume of novels written in Argentina since the publication in 1851 of Amalia, the first novel, doubled in the decade of the eighties. The exact figures quoted by Lichtblau are as follows: ${ }^{6}$

$\begin{array}{cc}\text { Year } & \text { Novels } \\ 1851-9 & 22 \\ 1860-9 & 17 \\ 1870-9 & 12 \\ 1880-9 & 101 \\ 1890-9 & 48\end{array}$

Thus, in the twenty years with which this thesis is now concerned, nearly one hundred and fifty novels are recorded as published. Of these, the six chosen form the bulk of novels in which Immigration constitutes a central preoccupation. This is not to say that immigrant characters do not appear in many other works, but the works to be examined constitute the small nucleus of important works which show a specific concern with the question of Immigration. They include, in La Bolsa and En la sangre, two of the most famous novels of the period.

The literature in question is essentially prescriptive rather than descriptive; it does not offer an 'objective representation of contemporary reality" but is a didactic and moralistic account, biased to suit a particular viewpoint. In short, it is a polemical literature, suffused with a rhetorical and even exhortative spirit. Traditionally, however, it has been loosely but insistently interpreted as belonging to either the school of Realism or of Naturalism, the two major literary styles fashionable in Argentina in the last quarter of the nineteenth century.

It is not proposed to enter into a lengthy exposition on literary definitions: neither comparisons with other works similarly labelled nor the shifting 
demarcation lines between the two literary 'isms', or indeed any other 'isms', are of particular interest here. But since both terms, Realism and Naturalism, have strong connotative claims, that what they are telling is not only an objective but even a scientific truth, a brief discussion on the use of these terms has been thought appropriate. Instances of specific criticism in this respect will be commented upon individually, but two examples will be given, representative of the general acceptance of Realism in the Argentine novel after 1880. The first is taken from J. Franco's Introduction to Spanish American Literature. ${ }^{8}$ Referring to the social changes and the various ideologies of progress, J. Franco cites the Argentine realist and naturalist novels of the last decades of the nineteenth century, as an example of a literature which reflected rather than advocated social change. The only two authors whose works are then analyzed are Martel and Cambaceres.

Myron Lichtblau, in his detailed bibliographical study, writes the following:

The 1880 's, in addition to witnessing the growth of the gaucho novel, saw the full expansion of realism in Argentine fiction. By realism we understand the faithful portraiture of life, the true characterization of events and personages, the careful objective observation and representation of actions and emotions. The realistic novel attempts to reveal with fidelity, in appropriate lights and darks and grays, in true proportion, the general atmosphere of the work and the individuals living in that milieu. In short, not a society looked at through rose-colored glasses, nor defiled by the perverted minds of villains, nor peopled with cherublike creatures and darling heroes and heroines, but a society taken from life's complexity and incomprehensiveness, breathing and exhibiting a combination of good and evil, of beauty and ugliness, justice and iniquity - this is what realism seeks to portray. (p. 136)

He concludes that 'eager writers sought to mirror that rapid change and portray the new society that was surging forth' (p. 138). The use of the word mirror, reminiscent of Stendhal's famous definition of the novel as 'a

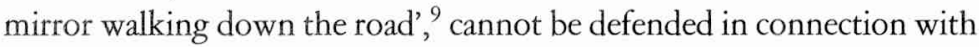
the works to be examined. Nor will the earlier requirements be met, that the novel should 'reveal with fidelity, in true proportion the general atmosphere of the work'.

The claims of Naturalism to objectivity are even more ambitious than those of Realism, and they have often been made on behalf of the novels to be examined. Most of the Histories of Literature refer to it; Lichtblau has a chapter entitled 'Naturalism in the Argentine Novel'; $;{ }^{10} \mathrm{G}$. Onega groups Cambaceres, Martel, and Sicardi under the heading of 'Los naturalistas'; ;' 
G. Ara, in his book on La novela naturalista en Hispano américa, ${ }^{12}$ devotes a whole section to Naturalism in Argentina and discusses it with specific reference to the works of Argerich, Cambaceres, Martel, Sicardi, and Grandmontagne. The link in literary criticism between Naturalism and the novel of Immigration, has thus clearly been established. The theoretical aspect of Naturalism was particularly suited to fit into the conceptual framework which prevailed in Argentina at the time, and which had found its chief inspiration in Darwinism, French Positivism, and Spencerian Evolutionism. ${ }^{13}$ In fact, Naturalism was the logical literary expression of an ideology which eschewed subjectivism and introspection. and which is distinguished in general by its disinterest and mistrust of metaphysical conjectures, and by its concentration instead on a scientific approach limited to the evidence of observable phenomena.

Naturalism, as a doctrine or manifesto, was set down by Zola in his short treatise entitled Le roman experimental. Based upon Claude Bernard's instruction in the field of medicine, Zola likens the role of the writer to that of the scientific experimenter, demanding the same objectivity and cool detachment. His purpose is to be that of determining the relationship of particular phenomena to their immediate causes, and is thus limited to recording a mechanism without seeking to investigate or to comment beyond his observations. Zola writes: 'la science experimentale ne doit pas s'inquiter du pourquoi des choses: elle explique le comment, pas d'avantage. ${ }^{14}$ The writer, therefore, ought not to approach his work with any preconceived ideological conviction which would prejudice his observations; neither should he seek to prove a particular theory; but above all, he should eschew all moral judgements. For morality has no place in nature, as already said by Taine; vice and virtue are chemical ingredients, like sugar and vitriol, and the naturalist novel should study man in his physiological state, as a product of nature. Characters are likened to animals in their outward appearance, in their behaviour, and in the treatment of their inner emotions which are usually expressed as instincts or appetites.

The ultimate aim of Naturalism was sociological for by exposing a given situation the possibility is afforded of changing it. (As mentioned, this task should not be undertaken by the writer, but merely inspired in others by his observation.) This point, which coincides with the spirit of optimism which characterizes positivist thought, is a very important feature which has often been misunderstood. It is the possibility of influencing the course of history which differentiates nineteenth century Determinism from the earlier theories of religious Pre-determinism or 
Pre-destination. ${ }^{15} \mathrm{~W}$ ith their belief in a pre-ordained, unalterable universe, these ideas are more akin to Fatalism and its demand for a stoical acceptance of an unknowable, irrational, and uncontrollable force against which either society or the individual are totally helpless. Zola, however, explicitly draws attention to a distinction, explaining Determinism as an open dynamic force in which by observing the causal relationship of phenomena, it is possible to influence their course merely by altering the determining factors. Zola writes:

Nous n'agissons jamais sur l'essence des phénomènes de la nature, mais seulement sur leur determinisme, et pas cela seul que nous agissons sur lui, le determinisme différe du fatalisme sur lequel on ne saura agir. ${ }^{16}$

This is the rationale behind the naturalist method, as expressed by Zola, and it is what is here understood as the spirit or motivating force of Naturalism. Its practice has manifested itself in a marked preference for the observation of the extreme, the abnormal, the diseased, the turgid, and the morbid sectors of society, depicted in a language which made frequent use of scientific terms and pseudoscientific explanations. It is not within the province of this thesis to comment upon the merits of Zola's theory or upon the success of its application in literature in general. But according to strict Zolian tenets, it is possible to assert that there are no naturalist novels in Argentine literature. A tenable, if extreme, view would hold that the naturalist novel is an impossibility in itself, for the total impassivity of the recorder is betrayed at the moment of selection.

Yet even if one were to disregard the basic subjectivity of the initial selection, and discard linguistic theories on the deficiency of language, which is sequential, to record the richness and complexity of reality, which is simultaneous, and if one were thus to judge the works on the basis of traditional definitions regarding the mimetic possibilities of art, the fact would still remain that all the works considered deviate from the true principles of the naturalist method, for it is evident after the most cursory reading that they have been written not with a desire to mirror society in order to inform it, but to distort its portrayal so as to influence it in the direction of an underlying purpose. In this sense, it would be more accurate to describe the works in question as being essentially thesis novels, whose aim by definition is to present a particular argument.

At a more superficial level, many of the distinguishing features which conform to the general concept of the naturalist novel can be easily detected, both in the inclusion of the depressed and alienated groups of society, and in the language chosen for their description. Thus, many of the works 
include lengthy descriptions of immigrants and sometimes also of criollos living in the most squalid conditions. In some, promiscuity and prostitution feature extensively, usually followed by venereal disease and meticulous reports of its more horrifying manifestations. This does not preclude attention to other diseases, with a marked preference for anything morbid. The adoption of these outer trappings of Naturalism needs further qualification. It will be seen that in most of the works studied, only the nonprivileged are observed from the vantage point of Naturalism, and that the criollo élite is still described in terms which are strongly reminiscent of the earlier romantic or sentimental novel. The reason for this distinction may be explained by a comment made by G. Onega who, writing about the naturalism of Cambaceres, notes that while in Zola's descriptions of the oppressed there existed the desire to attack and undermine the privileges of the ruling class in favour of the oppressed, in Cambaceres the force of Determinism is used as an argument to defend these privileges by illustrating the threats posed by the lower orders. ${ }^{17}$ To conclude, therefore, Realism and Naturalism are two labels which have been abused in their application to the novels under review. Realism is confined to the fact that they are set in a recognizable background and that their plots are verisimilitudinous, though rarely plausible. Naturalism is confined to the focus of interest of the novels, but its principles are severely betrayed by the rhetoric and selectivity of the authors. 
Inocentes o culpables has been classified by Germán García as 'la primera novela del inmigrante'. It was written by Antonio Argerich in $1884^{2}$ as an argument against the proposal by the then President of the Republic, Julio A. Roca, that the Argentine Government should pay for passage fares from Europe in order to encourage immigration. ${ }^{3}$ Argerich is explicit about his views on this and on other matters concerning Immigration in a lengthy Prologue to the novel. This is a particularly valuable part of the work, both as an illustration of opinions held on the subject and of the crudely superficial way in which the ideas of prominent European thinkers such as Darwin and Malthus are used out of context in order to support prejudice and cover up ignorance. Furthermore, it is valuable as a yardstick to measure the contents of the novel against the author's avowed original intention. Too often the work has been read under the shadow of the Prologue and interpreted as a manifest proof of the axiomatic proposition of the foreword, ${ }^{4}$ implied in the much quoted sentence: ' $¿$ Cómo pues de padres mal conformados y de frente deprimida puede surgier una generación inteligente y apta para la libertad?' (p. iv). ${ }^{5}$ Yet such a conclusion is not borne out by a detailed reading of the work, which either in spite of or because of many obvious technical shortcomings to be discussed in due course, reveals a more complex attitude than that proclaimed in the Prologue.

In the Prologue Argerich speaks out with one voice against Immigration, arguing on the basis of demographic and ethnic considerations. The original twin objective of the Immigration policy was, it will be recalled, to populate the desert and to whiten, i.e. improve, the population. With regard to the demographic question, Argerich claims that Immigration cannot constitute a solution, for although immigrants have an aboveaverage number of offspring, their physical constitution is so weak that in a few generations they will have died out: 'Tienen muchos hijos y muy grandes, pero nada más que grandes' (p. iii). He quotes Darwin as saying that change and cross-fertilization produce increases in size and fertility, but that this effect comes to an end after the second or third generation. He tries to substantiate this theory by stating that increases in population in Buenos Aires correspond with the figures of immigration and thus do not 
point to a sustained internal growth. He does not, however, give adequate references to support his argument, and one wonders on what evidence these assertions could have been made at so early a date as 1894 .

Argerich also mentions Malthus to argue against the artificial injection of an immigrant population, ${ }^{6}$ claiming that it will upset the fluidity of laissezfaire and cause problems of food shortage and urban overcrowding. This is one of the most blatant examples of the superficial way in which European ideas were transplanted to America, without proper consideration of the local reality. To talk of food shortages at that time and place, when Argentina was supplying thousands of tons of her soil's products to Europe, was plainly absurd. Argerich extends the Malthusian argument to the field of education and housing, saying that the country is not equipped to educate or to house vast numbers of people. His error consists in believing that educational facilities and housing, like food production for Malthus, are necessarily ruled by a rigid arithmetical progression and cannot be multiplied geometrically. His concern with the unimpeded flow of laissez-faire seems somewhat inconsistent, too, for he notes with regret the ascension of immigrants into the middle classes, fearing that such a development may upset the traditional structure of society in favour of a small criollo élite.

The strength of his argument against immigration, however, is not demographic but relates essentially to the quality of the human element entering the country. He cries out against bad, inferior immigration, although he offers no alternatives. He complains that Argentina imports only the highest breeds of animals to improve its existing livestock, ${ }^{7}$ yet is content to receive inferior human immigration, i.e. 'los rezagos fisiológicos de la vieja Europa' (p. ix), ${ }^{8}$ which, far from improving the quality of the native population, would cause it to deteriorate. His final warning in the Prologue offers a crucial point of contrast with the works studied in the former period, for while continuing to use the concept of civilization and barbarism as a frame of reference, Argerich employs the word barbarie not in connection with the native population, but with the immigrants: '... porque la República Argentina opera en estos momentos una evolución de la cual puede levantarse como un giganto o sumirese en una largan noche de barbarie' (p. ix). The long night of barbarism would be that caused by the continuing arrival of Italian and Spanish immigrants.

This reversal in the use of Sarmiento's formulation denotes a more selfassured faith in the importance and standing of Argentina, now unified into one nation, and which Argerich for his part would like to see developing gradually from within, with its existing population. 
The overtly polemical aim of Argerich is to alarm his readers and convince them that an inferior immigration is harmful to the progress of the nation. He states bluntly that he will set out to prove this via the example of the fortunes and vicissitudes of one Italian family which should be taken not as an exception but as representative of all immigrant families. He will tell their story in an allegedly scientific manner, demonstrating with mathematical clarity the inevitability of its final disaster. Most of the critics who have paused to consider this work seem mainly to have accepted the novel as a realization of the preceding statement of intent. Referring to Inocentes o culpables in his work La novela naturalista en Hispanoamérica, G. Ara states in a language which is strongly reminiscent of Argerich's own words:

... la forma novelística es un medio para la exposición científica.

Y como buen positivista va a darnos el fruto de una problematización según la cual de padres mal dotados han de nacer, por conclusión aritmética, hijos de frente estrecha y propensiones funestas para ellos y la sociedad. Todo esto lo hará sin trabas ni remilgos. El cuadro general es aritmético. La exhibición de sitios y vicios, puntualísima... La pretensión incluída en la tesis resulta caprichosa y falaz, como siempre que se generaliza sobre cosas humanas, pero Argerich supera las debilidades de su teoría, al fin lo que importa menos, con una técnica que evita caer en admoniciones y reprimendas."

L. Rusich, in his study of El inmigrante italiano en la novela argentina del 80, writes:

En resumidas cuentas, el cuadro que Argerich nos pinta de la inmigración italiana es totalmente negativo, en conformidad con la tesis enunciada en el prefacio de la novela. Pero mientras que en este prefacio el autor expresa el deseo de plantear el problema en términos antropológicos y sociológicos, en el desarrollo de la novela insiste más en la aplicación de doctrinas eugenésicas según las cuales de padres tarados deben nacer imprescindiblemente hijos degenerados y de propensiones funestas para ellos y la sociedad. ${ }^{10}$

Yet a careful objective study of the novel will reveal that it has strayed widely from the propositions of the Prologue, as observed by a contemporary critic, García Mérou, who alone writes: 'francamente hemos buscardo con ahínco un lazo que uniera ambas proposiciones, y nuestros afanes han sido infructuosos'. ${ }^{11}$ Argerich wrote a work which, even if of scant literary merit, ${ }^{12}$ is of importance as a socio-historical document. This does not mean to imply that Inocentes o culpables is a novel which mirrors the era in a realistic way, but rather that, in its very distortions and inconsistencies, it reflects some of the complex uncertainties which beset that particular age. It shows that while Argerich was theoretically preoccupied with 
the question of Immigration, he reveals an even deeper concern with the standards and values of his own criollo society.

García Mérou is damnatory in his criticism of Inocentes o culpables, seeing as the kernel of the novel's failure the lack of verisimilitude of its plot, a fact which for him mars any documentary value or aesthetic consideration of the novel. It is true that the story is based upon a series of events which are highly implausible, and García Mérou is not wrong in his judgement from a purely aesthetic point of view. As a social document, however, the interest of the work does not reside in the plausibility of its plot, but in the ideas and prejudices which can be elicited from it, and in this respect the gap existing between the prologue and the novel is itself particularly significant.

The author's original thesis, once more, is that the immigrants arriving from Europe are racially inferior to the native population and that they are physiologically so weak as to be prone, inevitably, to disease and decomposition. ${ }^{13}$ The argument behind this is, of course, that they will not solve the population problem either in terms of numbers or of fertility. Thus Argerich sets out to describe the history of what he says is a typical Italian family. He begins by recalling the arrival of the father, José Dagiore, a poor Italian immigrant who rises from shoe-shine boy to street vendor, becoming eventually the owner of a well-attended café. Dagiore marries Dorotea, the young daughter of Italian immigrants, who soon changes from the helpless victim of her family's wishes into a demanding, domineering wife, full of social ambition. The efforts of her relentless drive are rewarded, and she gains entry into the highest social circles. These, however, are shown to be hypocritical and corrupt.

The couple have three children. The eldest, José, is meant to typify the second generation of immigrants, and presumably his dissipated life is an illustration of the sort of contribution the country can expect from its inferior population intake. José suffers from a deprived childhood: his father is always too busy working at the fonda and his mother is neglectful of her family cares in her eagerness to escape from a life amidst a rough, uneducated immigrant community. He feels the disadvantages of his parentage even at school, where he has difficulty in keeping up with the lessons. The reason given is that his brain has remained underdeveloped through not having been exercised for several generations. As a young man he is too apathetic to work and he and his colleagues indulge in a life of physical and moral depravity.

At one point José meets Carlota, the young daughter of an impoverished patrician widow. They fall in love and he is resolved to change his way of 
life and become a worthy suitor of such a noble girl. But events stand in his way: first, he allows himself to be persuaded by his criollo friends to lapse in his regenerative determination, and he goes out with them once more on an evening which ends disastrously for him, for he unwittingly and under the effect of drink, insults Carlota and her indignant mother. In time he is forgiven only to discover, to his horror, that the evening has left a more permanent mark and that he is suffering from venereal disease. The progression of the ravaging illness is described in detail and with sympathy, but the end is inevitable, and José is driven to suicide.

The question asked in the final pages is the same as constitutes the title of the work: 'inocentes o culpables?'. It assumes that there are only two antithetical possibilities of viewing the outcome of José's life. He can either be declared innocent of its failure as the helpless victim of deterministic forces, or guilty as a free individual who has misused God's gift for free will, and chosen the wrong moral path. The impasse of the situation is clearly evident, for in either case, whether morally innocent and deterministically condemned, or whether free and morally guilty, the immigrant must inevitably lose and be declared undesirable.

The work carries the subtitle of Novela naturalista, indicating the author's wishes to write an 'experimental novel', i.e. an objectively recorded story which, in the manner of a scientific experiment, would unfold its plot logically, propelled by the strength of its initial situation alone. Thus Argerich ascribes to himself the role of an impassive observer whose evidence will prove an irrefutable point. In 1884, when Inocentes o culpables was written, Zola was a major influence in Argentine letters, decried by some for his immoral subject matters, admired by others for his scientific approach, and read by all. ${ }^{14}$ Argerich himself publicly defended Zola's work and gave a lecture on Zolian Naturalism in $1882 .{ }^{15}$ The influence of Naturalism in his own novel is clear but needs to be carefully defined. There is the usual fascination with poverty and debauchery, with diseases which spread their contagious net upon their pitiable victims, with doom-laden events whose outcome is predicted and explained in a language which purports to be scientific. ${ }^{16}$ And yet, as will be seen, the story as such does not develop according to naturalist principles, i.e., with mathematical precision and irrefutable logic. As it unfolds, so it loses the grip of its argument, becoming increasingly inconsistent and contradictory, and ending on a note which totally fails to reach the promised conclusion.

The story is built upon a triangular structure, each side representing a different stock characteristic of immigration. The first is embodied by Dagiore, ignorant and hardworking; the second by the socially ambitious 
Dorotea, and the third by José, their son. It is this last character who is the all important figure, for he is meant to illustrate the author's ideas on the future value of Immigration.

Dagiore is the prototype of the immigrant character who arrives penniless and ascends almost automatically on the ladder of financial success by means of perseverance and hard work. The basic anecdotal element of rise from rags to riches will be seen as a constant in the literature under review; the variant will come in the vantage point from which it is expressed. In Inocentes o culpables it is described in purely negative terms of opprobium. As an immigrant, he is there to fulfil two functions alone: to work and to reproduce. It is interesting to note the tone in which they are related. Both afford grounds for disapproval, the first because it runs contrary to the old Hispanic code demanding purity from the taint of manual labour, ${ }^{17}$ and the second, because of its associations with sexuality. Among exalted criollo society physical love is usually presented as the spiritual union of two superior beings, but among immigrants it is distastefully regarded as the lustful copulation of sub-humans.

Argerich cares not why the immigrant was forced to leave his native land; nor does he show any interest in the benefit that he may bring to Argentina. His concern is to put forward his own argument, which he does unfairly, abusing the privileged position of the omniscient narrator. From the outset Argerich adopts an accusatory tone, ascribing moreover base motives to anything that Dagiore may do. Thus Dagiore's attitude to work is described as though it were an uncontrollable vice, born out of necessity, but as a degrading and harmful disease:

Vagaba, luego, por calles y plazas con su cajón pendiente del hombro por medio de una correa, hasta que cansado se sentaba en el borde de la vereda de cualquier esquina. Allí quedaba perplejo con expresión de idiota: el cambio de clima y de hábitos le producía cierta nostalgia, - quedaba absorto, pensando en algún modo de ganar mucho dinero. (p. 2)

Unreasoned prejudice can be found in the following assertion, too: 'no ganaba nada, pero sin embargo, ahorraba peso sobre peso, - aberración económica que sólo puede explicar un inmigrante de la bella Italia' (p. 2). It will be recalled that in Alberdi's work, money was seen in a positive light, as a desirable asset of beneficial characteristics. The transitoriness and precariousness of this appraisal in Argentine letters was forecast, and the complete reversal in attitude towards it may be found in the following quotation in which Argerich seems to synthesize some of his prejudices and show Dagiore's hankering for money as an overpowering atavistic force 
which dominated his mental and physical existence. Thus work and thrift are expressed in terms of feverished passion, even lust:

A las once, hora del descanso, se sentaba apartado a comer su gran pan italiano y pensaba febriciente en el dinero, aislándose en su pensamiento para expandirse en monólogos mentales: mucho dinero, dinero y nada más: su hambre de oro no expresaba ningún deseo, - era la animalidad descarnada del avaro. Quería ahorrar y así lo hacía, - sobre su hambre, sobre su sed, a despecho de la salud y de la higiene de su cuerpo: ahorraba por ahorrar o tal vez por hábito heredado en la falta de costumbre de gastar dinero, cumpliendo así, de una manera inconsciente, la misión de ahorrar todo lo que no habían podido comer sus antepasados. (pp. 2-3)

Only at the very end of this impassioned outburst does the author seem to remember his vow to expose matters scientifically, when he offers the idea of inheritance as a causal explanation for his character's extreme behaviour. Having condemned the immigrant for his first crime, the desire to work and to save, Argerich proceeds to demonstrate his character's sexual bestiality. The following is an extract from the scene of Dagiore's wedding night. It is a close-up picture in which exaggeration and distortion are expressed in crude plastic images:

De pronto una sonrisa de bestia se dibujó bajo sus bigotes rubios y poblados. Sus ojos, de un color celeste percudido, relampaguearon con todos los impetus desbordados del deseo y su nariz rojiza emanaba vapores de fuego: tambaleando se dirigió al tálamo, pero a los cuantos pasos se volvió: buscó uno de los extremos del mantel y se restregó los labios: el fauno no quería repugnar, trataba de desinfectar su boca de las miasmas que contenía. (p. 10)

After having consummated the marriage, Dagiore disintegrates into an almost larval state, in which his erstwhile robust and degenerate animal features become flaccid and hidden by their gluey secretions:

El sátiro no podía estar más deforme. El pelo revuelto y enmarañado le ocultaba su frente pequeña y deprimida. Los ojos supuraban unas lágrimas glutinosas de color blanquizco, con vetas amarillas. De la boca le caía una baba espesa que descendía por la camisa desabrochada a su pecho ancho y exuberante de vegetación cerdosa. (p. 13)

Other instances in which Dagiore is referred to in terms of animal metaphors occur as follows: 'fauno lascivio' (p. 14), 'sensualidad de sierpe: (p. 15), 'el hocico húmedo del fondero' (p. 20), 'orgullo de reptil' (p. 22). Yet it is interesting to note that the worst excesses of Argerich's venom, resulting in a grotesque caricaturization of an immigrant figure, are concentrated in the first chapter of the novel. Once the image of greed and lust 
has been established, Dagiore ceases to be of any major interest. His remaining duty in the furtherance of the plot is to engender a son. In this act he is seen to combine both his vice for work and thrift, and his vice for lust, for he conceives his son when feverishly weakened by some eighteen or nineteen hours of incessant work. The consequences of this excess upon the unfortunate child will be studied in due course. After this, Dagiore becomes a totally expendable character, and following a gradual isolation from his family and from the centre of the novel, he is suddenly declared to suffer from a persecution complex (p. 230) and is summarily discarded as being mad. Some twenty pages later (p. 250), as if remembering a commitment to causality, Argerich explains the Italian's madness by a blow he had received in a fight with another character. However, the connection is not developed and this example illustrates the very superficial treatment of ideas which have been declared fundamental to the work. Dagiore is the dominant immigrant character in the novel, depicted to represent all of his kind. Other immigrants form an unimportant part of the backdrop, consisting mainly of people who are in similar positions to Dagiore, such as his parents-in-law and his colleagues and partners at work. Furthermore, mention is made of immigrant midwives, beggars, prostitutes, and brothel owners. Many of the references are strongly derogatory such as 'gorda y desvergonzada italiana' (p. 151); 'gringa sarnosa' (p. 152); 'gringa de porra' (p. 154); 'mendigos italianos de cara torva y frente deprimida' (p. 307). Although the impression is gained that immigrants are numerically an important component of society, they are relegated in the plot to minor sporadic appearances. All those with whom Dagiore has any personal connection are Italians, but the clientele of the more prestigious Cafe Tortoni are French, and the prostitutes come from different countries, including 'una flaca compatriota de Lord Byron' (p. 174).

The second facet of the novel evolves around the figure of Dorotea, who from the third chapter onwards assumes an important role. The change of direction in the work, to say nothing of its total internal lack of consistency, can be grasped from the difference in the following interpretations of Dagiore's choice of a wife. In Chapter I it is said that he was interested in acquiring what can only be termed as a workhorse:

Fue entonces que decidió casarse. Así, según sus propias palabras, tendría una sierva...

Puso en ésto el mismo celo y perspicacia con que escogía un trozo de carne en el mercado para las provisiones de su fonda. Las examinaba, les calculaba 
la edad que podían tener, su vigor para el trabajo y el estado de fortuna de los padres. (p. 6)

The emphasis is clearly on the venality of Dagiore and his unfeeling crass materialism, offending against the sanctity of matrimony. Yet in the following transitional chapter, a softening of attitude is apparent, for in dealing with exactly the same subject, i.e. Dagiore's choice of a wife, more affectionate and sentimental terms are used: 'él había soñado una mujer modesta, que alentase en su atmósfera y quelo ayudase en los trabajos de su negocio; algo, en fin, como una socia' (p. 22). This manifest inconsistency in the attribute of the narrator reflects not only the extreme artificiality of the story, but also illustrates its arbitrary and rhetorical nature. Characters and situations are manipulated with total disregard for the internal logic of the work. Dorotea is the daughter of Italian immigrants, yet she shares none of the grasping characteristics of her parents and other compatriots. Her purpose in the novel is not to reinforce the biological thesis, but to illustrate a totally different problem: that of the social ambition and social climbing practised by the immigrants. It will be recalled that in the Prologue Argerich voiced his disapproval of the way in which immigrants sought entry into the middle classes.

Dorotea is a totally inconsistently drawn character. She is changed at will and made to fit any role that will illustrate the author's differing viewpoint. When first encountered she is the helpless, innocent victim of her parents' wishes, and then of her husband's domination. In spite of her ancestry, her mind is not peopled with lascivious thoughts about money or sex, but she is endowed with 'un alma en reposo' (p. 7). She is clearly not important at this stage as an evil immigrant herself, but rather as the victim of one. Therefore Argerich slips into the literary cliché of the pure virgin, whose brutalized husband assaults her, 'profanando aquel turgente seno de nieve' (p. 12). Soon afterwards, however, the author draws attention to her 'labios gruesos y fuertemente encarnados' and to the power that she could exert via her fresh and youthful body. Thus, when Dorotea eventually becomes the focus of interest of the second stage in the novel, she loses her innocent mask and assumes that of calculating ambition. She seizes upon the first opportunity to better her social position:

El negocio de la tienda era lo que tanto la excitaba. Le parecía una idea soberbia. No era el deseo de servir a sus padres ni un golpe nervioso lo que la hacía cambiar de opinión en el asunto. Había encontrado una puerta para dar escape a la vanidad que la ahogaba y sólo el cálculo la impelía a obrar. (p. 37) 
Her aim is to be accepted by 'la gente decente', and she uses her charm and attraction to gain an entry into the houses of old established criollo families. It is obvious, as García Mérou has pointed out, that her comparatively speedy acceptance into society is as implausible as her separation from her husband, who sleeps at his fonda while she resides in their new home, is unconvincing. ${ }^{18}$ And yet both characters symbolize neatly their dual purpose in the novel: the one as a danger to society because of his degenerate physical condition and his boundless greed, and the other, because of a social drive which threatens to upset the traditional balance of society. It is interesting to see that ultimately Argerich insinuates that Dorotea is ambitious, calculating and an opportunist, not because she is an immigrant but because she is living in a young, vibrant society in which the social positions of the different strata have not yet been delinated or defined. It is the changing face of society which is regretted, in which the acquisition of money facilitates the pursuit of social standing. Argerich declares: 'como es natural, a un pueblo de ayer le faltan antecedentes y en este tumulto típicamente plebeyo todos se afanan por crearlos para distinguirse' (p. 23).

The portrayal of Dorotea is interwoven with a critical description of a wide cross-section of society, ranging from the lowest members of the underworld to high Church and Government officials. Set in the centre of Buenos Aires, the impression given is that of a small town, in which everyone meets continuously either in the streets, at the cafés or, most frequently, in the brothels. There is one hilarious scene in which José and his three criollo friends, after having been to several brothels in just over two hours, decide to finish off the evening at yet another famous pleasure house. There they choose a desirable young German prostitute who is then called away to serve the needs of higher ranking gentlemen. Offended, they decide to fight for their honour, only to find themselves confronted by Dr Ferreol, a Government Minister and father of one of them. With a great aplomb Ferreol declares that he and his three companions were there simply looking for his son. The incident is solved in the normal fashion, through influence and corruption:

Al día siguiente Ferreol fue muy temprano a visitar a su colega de la Guerra y Marina y arregló con él en que ese mismo día ingresaría Víctor a la Armada sin permiso para bajar a tierra. Lo demás no tuvo ulterioridades. El Comisario aprobó la conducta del oficial y le pidió que silenciara el suceso. (p. 274)

There are only two idealized characters in the novel and they are Misia Carlota and her daughter, both remnants from an earlier age in which the 
patrician class ruled with the elegant ease of unchallenged superiority. They maintain their dignity even when surrounded by the crass materialism of the rest of society. The other criollo characters are all members of society which is noted only for its hypocrisy and for its moral degeneration. This society comes under attack for hypocrisy, both at the superficial level of its social habits, and at the deeper accusation of professional opportunism and corruption.

Argerich's loss of illusion can be felt in the following lines: 'puede decirse que hay dos patrias. Una, que tenemos en la imaginación, y otra, que existe realmente y que no se la conoce on no se la quiere conocer' (p. 193). At one stage Dorotea, who has wished fervently to gain acceptance in the Ferreol household, is invited by Dr Ferreol, the head of this neighbouring family, to stay on for dinner. She refuses, but when pressed a second time, accepts. The author makes the following observation: 'poco al corriente de las forzadas fórmulas que usa la buena sociedad, elle debía haber rehusado nuevamente, pero no lo hizo' (p. 74). At first it may seem that the butt of this remark is the lack of savoir-faire of the social climber, yet when viewed against the wider context of criticism of criollo society, the gentle irony contained in these words can more readily be appreciated. Argerich is attacking not only Dorotea but also the artificiality and lack of sincerity of the criollo social code. The same criticism is made in the following comment:

Un apretón de manos, dos besos maquinales y unas cuantas palabras de convención, que se cruzaban sin sentido. Las más de las veces, tal era el hábito de repetir siempre las mismas cosas, sin escuchar ni hacer las debidas pausas. (p. 211)

It is interesting to note that Dorotea is criticized and shunned for her lack of modesty and of manners, and not overtly at least for her immigrant provenance: 'miren la desvergonzada, presentándose con ese escote: está visto que ya no puede reunirse la gente decente, porque la chusma tiene entrada a todas partes' (p. 196). The criollos with whom Dorotea comes into a more intimate contact are Dr Ferreol and his friends, and 'el Mayor'. The latter becomes her lover, after he interferes in a family squabble during which Dorotea is beaten up by her brutal husband. And yet 'el Mayor' is not placed in a completely antithetical contrast to Dagiore. He may be overtly less brutalized, but he is far from a model figure:

El Mayor distaba mucho de ser un héroe o una figura verdaderamente interesante: no pasaba de ser una de tantas vulgaridades que nacen porque nacen y viven porque viven. (p. 112) 
He is a mediocre man, vulgar and unworthy. His conduct towards Dorotea, whom he beguiles into a brothel, and towards Dagiore, whom he cynically uses to further his affair with his wife, is utterly despicable. An added touch: his love letters to Dorotea are full of spelling mistakes.

The others seem no better. A bishop is found to be one of the most assiduous customers at a brothel; there is a fraudulent doctor of medicine who learns his art from the prescriptions given by other doctors, which he finds at his friend's chemist shop. The most important criollo character is Dr Ferreol, for in him can be found, although in a less exaggerated form, the failings of both Dagiore and Dorotea. He shares the former's avarice and lasciviousness, and the latter's social ambition. Thus, 'cuidaba de su caudal como un perro hambriento el hueso que roe, pero era pródigo a manos abiertas con los dineros públicos' (p. 69-70). The same strong language used in connection with Dagiore is encountered here in 'perro hambriento', but the invective is not sustained as long. Also short but damnatory is the following pronouncement: 'su animalidad olfateaba solamente al sexo' (p. 71).

Both Ferreol and his companions are unfaithful spouses, said to be weak of flesh, and become frequent visitors to the brothels. The feature that defines Ferreol most accurately, however, is his social ambition which success turns into political opportunism. In his youth he was a poor lawyer who charmed his way into marrying the daughter of a wealthy family. His mother, Misia Pepita, is short, fat, middle aged ' $y$ de limitada inteligencia', and his father is not even mentioned, which may seem surprising in a work which purports to illustrate the workings of Biological Determinism. The obvious inference is that only immigrants are influenced by biological laws, so that this inconsistency in the inner logic of the work merely illustrates the nature of the prejudices of the author, and is a further example of the bias with which he expresses them. Ferreol, the clever and astute young lawyer, rises first to the rank of Deputy and then, at the personal instigation of the President of the Republic, becomes a Cabinet Minister. The success of his career is achieved at the cost of pleasing and mixing with everyone; he seems to bring the same sort of drive as Dorotea to his ambition, for he is always calculating and ready to use people.

The telling, fundamental difference between the two sets of characters: the immigrants and the criollos, lies not in what is said about them, for this has been seen to coincide at times, but how the same events and traits are related, and the different impression that they are set out to create. There is a perceptible lessening in the tone of the invective on the part of the author, but if attention is paid to the plot rather than the rhetoric, then it 
becomes clear that the work contains a considerable amount of serious criticism of criollo society. Argerich condemns the members of the new middle class on several counts, but mainly for their own hypocrisy, their social pretensions and their moral and political corruption.

The disadvantages of José's physical inheritance are compounded by the disadvantages of the environment into which he is born. Both forces of Determinism combine to lead him inexorably upon a pre-established course:

En su inocencia nada sabía del medio en que se iba a desarrollar su vida; pero esa atmósfera, a la cual estaba completamente ajeno, empezaba a incomodarlo y a tender la red de acero de su influencia para dirigirlo maniotado en el tumulto de la vorágine social.

Todo estaba pre-establecido. Todo lo habían ordenado voluntades y cerebros anteriores. (pp. 30-1)

The third facet of the story, evolving around the figure of José, strays even further than the last from the original intention enunciated in the Prologue. José was to have been a clear illustration of the workings of Biological Determinism; he was to have been the character that proved conclusively that a good, healthy, and wholesome issue could not come forth from inferior immigrant parents. Argerich prepares the scene placing great emphasis on the question of heredity and its unavoidable effects. José is said to have been conceived at a direct disadvantage resulting from his father's avarice and his mother's unhappiness. The idea that children are affected by their parents' condition at the specific moment of conception, is given with scientific assurance. It is here reproduced in full:

También hay otra observación a hacer: si recordamos cuando se casó Dagiore, en que cada noche se retiraba al tálamo postrado por el trabajo que le demandaba la Fonda y su avaricia, tendremos más luz para darnos cuenta de la apatía horrible que dominaba a José, analizando los antecedentes de su venida al mundo en el instante mismo que fue concebido.

Aceptamos con un filósofo que no produce el hombre manifestaciones puramente físicas ni puramente morales; pero en un ejercicio manual, - el de un lustra-botas, por ejemplo, - se puede cansar la cabeza, mas este ejercicio no deja ni puede dejar huellas benéficas en el cerebro, porque no cultiva la inteligencia; el cerebro se cansa por acción refleja y porque es parte integrante del organismo.

Dagiore, lo recordamos una vez más, se retiraba al tálamo postrado de cansancio, y como hemos apuntado, no eran solamente sus miembros los fatigados, porque los centros nerviosos, irradiando al cerebro esa postración, hacían que el cansancio se comunicara a su alma, por decirlo así.

Ahora bien: ¿no está perfectamente comprobado que los hijos se resienten de la situación en que se encuentran sus padres en el momento de concebirlos? Si 
el temor domina a los progenitores en ese instante o uno de ellos se encuentra borracho, resultará seguramente un ser débil y predispuesto a infinidad de enfermedades.

Dorotea asustada y Dagiore rendido por la fatiga, al darle la vida a José, le transmitieron esa debilidad que podríamos llamar del momento funcional, agregada a la debilidad congénita de sus cerebros toscos. (pp. 247-8)

Argerich makes repeated references to José's weakened constitution, as if to demonstrate the downward trend that must be expected from immigration:

Era hombre por la talla y por algunas ideas, pero los que están familiarizados con el análisis y constatan en sus observaciones de todos los momentos que hay abismos en cada detalle, sólo podrían tenerle en tal carácter como se reputan plantas a esas creaciones artificiales de invernáculo que se elevan a gran altura creciendo viciosamente, pero que sacándolas del calorífero, no tienen eficacia propia para la lucha y languidecen y mueren al primer combate crudo de la atmósfera. (p. 118)

The son does not inherit his father's robustness and hot-bloodedness. His life force is progressively sapped by an unexplained weakness which affects his bodily and his mental constitution. He is a poor student, lazy and unintelligent. Nor does he inherit his father's avarice, which has been explained as an atavistic force but which seems to have stopped with Dagiore, for José is disinterested in money and of a generous nature. Weak, apathetic, José does not inherit his mother's social aspirations, and in fact he moves quite freely in criollo society and seems as attracted to its lowest echelons as to the élite. There is, if anything, a suggestion that because of his deficient education and familiy life he was drawn to surroundings of vice, although no reason is given as to why his criollo friends were similarly attracted. On the other hand, there is no suggestion that his love for Carlota was motivated in any way by social climbing. In fact, José is visibly superior to his colleagues, whom García Mérou dismisses as 'pilluelos de baja estofa, ${ }^{19}$ but who are the sons of élite families and the only representatives of criollo youth. José leads a useless, dissipated life, but so do all his criollo friends. Moreover, he is more honourable than they are, for one of them, the one who introduced him to the brothels, falsified his father's signature on a cheque, and when José was accused of this crime, he reacted bravely and with much dignity. As a group of youths, they are wastrels, arrogant, and rowdy, and José is the only one to feel any sympathy for Josefina (the prostitute who goes blind and dies of venereal disease) and who acknowledges that they as a group must have infected her, and are somehow responsible for her death. This reaction of José is 
symptomatic of the degree of attention given to causality in the work. An event is 'explained' back to its immediate cause, but leaves a whole series of much more fundamental questions unanswered. Thus, why did Josefina become infected and not the others?

It is clear that José is not a direct mathematical progression from his parents. He does not inherit their particular bad qualities, and, perhaps rather surprisingly in view of the ideas expressed in the Prologue, the author does not refer to him specifically as an immigrant's son, apparently forgetting the main point of his thesis. As José becomes increasingly assimilated into criollo society, so the author seems to drop the arbitrariness of his thesis and to develop a measure of sympathy for him. The reason for this appears to be that when Argerich is dealing with Immigration, he does so from the vantage point of a polemical argument, and with obvious lack of knowledge of the society he is describing. He paints in wide brushstrokes of strident colours. When, on the one hand, he writes about criollos, he shows a deeper understanding for his subject, and his portrayal, whilst still critical, becomes somewhat more subtle and subdued.

On three occasions Argerich refers to the nobility of José: first when he is said to feel for his father 'un noble sentimiento de amor filial' (p. 226); then, when he gambles with his friends out of 'un noble entusiasmo' ( $\mathrm{p}$. 229); and lastly, when said to have, by the end of the novel, only 'ideas nobles y dignas' (p. 284). His death, which was to constitute the irrefutable illustration of the theory of Determinism, is not presented as the inevitable consequence of determined events. He is, it is true, the one to be fatally wounded by venereal disease, but two of his native-born companions are also affected and there is no reason to suppose that they may not undergo similar tortures:

- Pobre José: quién lo hubiera dicho entonces, agregó Juan Diego.

- ¿Y a Vds. no les ha sucedido nada? preguntó el abogado.

- Nada: parece que el pobre José fue el solo desgraciado.

- No tanto: a mí y a Víctor también nos pringaron.

- ¿Qué barbaridad! replicó Andrés, por decir algo.

- ¿Qué le vamos a hacer? Así es el mundo. (p. 303)

It is ironic that after having prepared the scene so carefully, Argerich should cause his character to die neither as the innocent victim of Biological Determinism, nor as morally guilty in his exercises of Free Will. As one of his friends comments, José dies as the unfortunate target of the capriciousness of Fate, a blind force, impassive, irrational, and totally undiscriminating in terms of class, race, or morality: 'pues yo creo, replicó Juan 
Diego, que éso sucede porque sucede, y el pobre José tiene tanta culpa de lo que ha sucedido como el transeúnte a quien aplasta un ladrillo que cae de un andamio' (p. 308).

What then is the importance of the final exoneration of José Dagiore? Does it suggest that not all immigrants are to be condemned since José was defeated not by his ill-disposed inheritance, but simply as one unlucky individual? The answer to this perhaps appealing hypothesis must surely be negative, because by placing exaggerated emphasis on one final detail, it fails to take into consideration the overall context of the work. This, as has been shown, is marked by its insistent belief in causality and in the overriding influence of deterministic forces as an argument for condemning immigration. And if towards the end José manages to escape from the constricting tentacles of Determinism, and to die a victim of Fate, he does so at a stage in the novel when he has already ceased to represent the future generations of Dagiores. It is simply that, in line with other observed inconsistencies, the didactic figure has given place to the sentimentalized fictional hero in what has become a banal love story.

It would be more apposite to ask why does a work whose main thesis has been proclaimed with such forthright assurance, deviate in so many respects from its promised trajectory. For, in the first instance, Inocentes o culpables fails to illustrate the ideas that are set out in the Prologue and implied in much of the work itself. The story fails to prove the demographic point raised in the Prologue because, as illustrated above, it offers inconclusive proof that the offspring of immigrants are biologically weaker than the rest of society. Furthermore, the story fails to prove the ethnic consideration raised in the Prologue, implying not only the barbarism of the immigrants, but also the superiority of the native population. While the former are strongly denounced in the original presentation of Dagiore, the accusation is noticeably softened as the work progresses. The criollos, on the other hand, are far from idealized, and it is interesting to note that their faults are not declared to be the result of Immigration, but are explained as the uncertainties of a still young and evolving society.

The work, however, fails even more strikingly as a portrayal of immigration, when one considers the quantitative aspect of its role within the story. Its specific treatment is concentrated on to the first two chapters and is subsequently reduced to brief and sporadic mention. With Inocentes o culpables a certain stock-type immigrant figure emerges. Dagiore is one of its crudest, most exaggerated forms, who epitomizes greed, avarice, and lustful bestiality. Thus, he is ridiculed and despised for fulfilling precisely those functions for which Immigration was originally instigated, i.e. 
working and reproducing. The artificiality of his depiction, its lack of immediacy is, moreover, an indication of the wide gap of knowledge and interest existing between the author and the immigrant sector of society which he was seeking to portray. This is confirmed by the portrayal of Dorotea which, seeking to illustrate social ambition, becomes principally a vehicle for describing the moeurs of the criollos. More interesting is the figure of José which, while it is treated in its immigrant quality, continues to be presented in a negative light, but which, as it develops in the story, acquires positive characteristics, its links with the past having become blurred and ultimately forgotten.

Thus, the original assertion that Inocentes o culpables is the first novel about Immigration must be placed against the conclusion reached, which shows that it is a novel about Immigration insofar as this is its intended aim, and that insofar as this aim is carried out, the portrayal is totally condemnatory. Yet what must be weighed against this assertion is the author's inability to sustain his treatment of Immigration or to develop it beyond the artificially drawn stock situation. 'In short, 'la primera novela del inmigrante' only comes to life when it ceases to be that, and reverts to the more familiar surroundings of porteño society.

There are certain observations about the portrayal of Immigration which are significant both in themselves and as beginnings of a trend that will continue to be found throughout this period of massive immigration. The most dramatic is the qualitative change undergone by the portrayal of Immigration from the works considered previously. In these, Immigration was a positive, beneficial force, an axiomatic desideratum which, while it came to be qualified in Alberdi, was never essentially challenged. In the period studied at present, the position has become reversed, and while not all works advocate against Immigration, they depart from the basic assumption of the superiority, in varying degrees, of the native population. 
The next work to be considered is En la sangre, a cautionary tale illustrating the dangers attendant upon Immigration.

The son of a celebrated French chemist and an upper-class porteña of British descent, its author, Eugenio Cambaceres, belonged to the highest echelons of Argentine society, both by birth and by occupation. He was a wealthy landowner, a sometime lawyer and a politician; furthermore, he was noted as the typical 'hombre del ochenta': widely travelled, a brilliant causeur, and a lover of the arts. ${ }^{1}$ En la sangre was Cambaceres's fourth and last book. It was published in 1887, first in serial form in the journal Sud América, and then in book form in October of that year.

As suggested by the title, the thesis of the work is presented by means of a convenient metaphor, namely, blood. Its symbolic usage as the life force whose purity must be preserved, can be traced to Antiquity and no doubt beyond. ${ }^{2}$ For those who had ties linking them with Hispanic culture, however, the term had acquired an added significance, given the excessive preoccupation with purity of lineage which for historic reasons prevailed in the Peninsula from approximately the middle of the fifteenth century onwards. Until then, limpieza de sangre signified mainly freedom from bastardy, but from that date the term began to be used with increasing frequency to denote purity from Jewish and Moorish blood; after the conquest of the Indies, it applied also to the blood of heretics. This essentially ethnic preoccupation was converted in time into a predominantly social concept so that pureza came to denote also freedom from the taint of manual work. ${ }^{3}$ Both strands, the ethnic and the social, are present in the prejudice expressed by Cambaceres.

Yet, however much the basis for a prejudice remains the same, which in this case can be seen as the preservation of the hegemony of one group to the exclusion of another, the reasons given to defend this prejudice alter according to changes in the ideological climate. The enlightened, liberal elite of Argentina in the late nineteenth century, so appositely represented by Cambaceres, would most probably have recoiled with distaste at the thought of any resemblance between their advanced ideas and those of an outmoded, retrograde Hispanic heritage. The reason for this was that they wished to forget their inglorious Colonial past and saw themselves, parti- 
cularly in cultural terms, as the heirs of the most modern thought in England and France. This, as already stated, was materialistic in outlook and scientific in its approach. And so the ideas of Determinism, stating that everything that happens is determined by a necessary chain of causation, were invoked to support prejudice and help to keep at bay the growing threat posed by immigration. Racial characteristics were presented as inherently immutable, transmitted by inheritance in an inevitable, inexorable process; from this it also followed that it was sufficient to demonstrate the ills of one member of a racial group in order to implicate all the rest and all future generations. ${ }^{4}$

This is the unequivocal message underlying En la sangre. Blood constituted a conveniently ambivalent metaphor in that its traditional emotive resonance co-existed easily with theories about its specific biological properties, an ambiguity moreover, which aptly reflected the preoccupations of the era.

The purpose of this study is to examine the way in which Cambaceres expressed these ideas in En la sangre. The most significant aspects have been considered to be the story itself; the structure into which it has been organized; the presentation of the characters, with particular attention to the protagonist Genaro as the principal exponent or 'proof of the author's thesis. A detailed analysis of the use of animal imagery has been included in support of the hypothesis that the author's derision of the criollo lower and middle classes differs in kind, not just in degree, from his hatred of immigration. Finally, there is included a questioning of the work's realism, as accepted by most critics.

The plot of En la sangre is of the utmost significance. It does not, as is the case in many thesis novels, merely provide a convenient background against which certain characters argue out a particular theory, but it constitutes, in itself, the argument it wishes to expound. This is pursued at two levels: uppermost lies the anecdotal, which is, as stated, an illustration of the workings of biological determinism and, in turn, this is supported by a carefully wrought structure which too is consistent with the ideology of causality.

The story evolves around the futile attempt by the son of immigrant parents to overcome through marriage and assimilation, the influence of his manifestly inferior inheritance. The plot is straightforward, invevitable: Genaro is the native-born son of an Italian couple who came to Argentina penniless, marked with a primitiveness and a brutality that will prove permanent. His birth, in a squalid conventillo, is described in its physicality, giving detailed information regarding the progressive stages 
of a difficult labour, helped by a coarse Italian midwife. The scene takes place almost in public and is further debased by the noisy comments made by the other inmates of the conventillo; women who were roused by the difficulty of the labour and men by the sexual connotations of the birth. Announcing almost prophetically, the violence at the end of the novel, the noise becomes aggravated by the uninterrupted hammering of the indifferent, callous father of the child. The chapter ends in a grotesque crescendo of sounds: 'la animación crecía en los grupos de inquilinos; las mujeres, alborotadas, se indignaban; entre ternos y groseras risotadas, estallaban los comentarios soeces de los hombres' (p. 15). ${ }^{5}$

Burdened by his ancestry and his environment, Genaro achieves a remarkable degree of success early in his life, for which he is never given credit, while his frequent displays of crass opportunism leading onto dishonesty are highlighted at every turn. The reason for this selectivity becomes apparent as the story unfolds. It is as if the narrator, exercising his omniscience, knew all the time that any mark of improvement on the part of the protagonist was bound to become frustrated by the sheer weight of his past history and was therefore not worth serious consideration. Upon his father's death and with the initial encouragement of his mother, Genaro becomes apprenticed to a reputed lawyer, showing much promise and ability. From there he goes on to university, where he seems well-liked by his colleagues; he, however, feels at a disadvantage in the presence of their innate superiority, and in a fit of panicking self-doubt, preceding a crucial examination, Genaro succumbs to the temptations of cheating. This is his first really dishonest action, and it is presented as the inevitable result of his essential amorality, and as the inevitable cause of futre crimes. Eventually he graduates as a lawyer, but is not attracted to the mediocre existence open to him. In fact, in a brief inner debate in which Genaro expresses his revulsion for the humdrum of everyday life, he comes remarkably close to Andrés, the upper-class hero of Cambaceres's previous and best known novel, Sin rumbo. ${ }^{6}$ Yet, whereas a certain elitism accompanied by a feeling of hastio is seen as a fitting mark of sensitivity in the upper-class Argentine, in Genaro it is viewed suspiciously, as a sign of social ambition and love of ostentation, and ridiculed accordingly. Thwarted in his attempts to penetrate society via membership of the exclusive Club del Progreso, Genaro unscrupulously seeks financial and social success by marrying a criollo heiress. He achieves this by seducing the daughter of a rich and respected family, Máxima, who, having become pregnant, is forced to marry her unworthy suitor to the utter amazement of her relatives and friends. 
In order to escape from shame and gossip concerning the premature birth of their child, the young couple leave for one of the family estancias. Here Genaro witnesses the wastage that still persisted in many large tracts of unexploited land in Argentina, and is eager to bring discipline and efficiency into operation. Yet for this he is despised by the narrator, who sees in such a programme only the workings of an avaricious materialistic immigrant and compares them unfavourably with the noble, disinterested attitude of the criollo landowning class.?

In the meantime, Máxima's father has been taken ill in Buenos Aires, and Genaro is the only close relative to be present at his death bed. He inherits a vast fortune through his wife's claim, but also manages to lay his hands on an equally vast sum of money which was lying unaccounted for in a safe, and it is this secretly acquired cash which finally leads him towards total financial and moral ruination. He invests the money in an uncertain market whose hitherto spectacular gains are beginning to crumble, and he ends up by losing it all. Then, in an effort to regain some of his losses, he gambles away most of his wife's inheritance. Defeated and humiliated, Genaro sheds his veneer of respectability and reverts to his father's primitive and brutal ways, in a final display of crude physical violence. The last scene is that of Genaro callously assaulting his wife. The message is all too clear: brutality was all he had ever received from his father, and all he would ever be capable of offering to society.

Obeying the inexorable dictates of the blood, the situation set out at the beginning of the story has run its full course, following the only path possible, and fulfilling the sombre expectations hinted at throughout the work. Each event was the result of the previous one, and led, inevitably, to the next. The message of the plot is reflected and reinforced by the overall structure on which it has been constructed. Causality is the most important factor in the ideological framework of the work, and its laws are well served by a story which develops in a strict unilinear pattern, each chapter following chronologically and sequentially from the previous one. Nothing is included that is not directly connected with the central purpose of the plot, for in the world of determinism, side issues and loose details are not possible.

This overall pattern, moreover, reflects the relative importance attached to the dual preoccupations of causal determinism, i.e. inheritance and environment. Thus, the work is roughly divided into two sections, each placing great emphasis on the influence of the particular force at work. In the first part the overriding concern is biological, and this is borne out by the importance attached to the protagonist's parents, and to the social 
characteristics which have shaped them in their hideous form, and which burden Genaro for the rest of his days. In the second, greater attention is given to the new environment in which Genaro moves, but which ultimately proves powerless to alter the course pre-established by the forces of inheritance. Thus the predominance of biological forces over environmental ones is upheld at the organizational level of the work. The correspondence of structure with content can be detected at an even smaller scale. For example, the opening lines offer a logical beginning to the story of Genaro's life, by giving a striking description of his father, Don Esteban: 'De cabeza grande, de facciones chatas, ganchuda la nariz, saliente el labio inferior, en la expressión aviesa de sus ojos chicos y sumidos, una rapacidad de buitre se acusaba' (p. 13). This description, which is a concatenation of stock characteristics revealing the subjectivity of the author, is based upon the idea that criminals can be identified by certain physical features. ${ }^{8}$

Stringing together a number of physical features with distinctly pejorative connotations, the author moves from an outward objective view towards an inside appraisal of the character's mind, ending with a climactic moral judgement. The measured rhythm of the prose, with the accent falling on all the descriptive words, reinforces the venom of the portrayal. The implications in Don Esteban's brutalized appearance are clear enough: his large head suggests a mongoloid trait; his flat features are an obvious sign of dullness; his hooked nose links him indirectly with the discredited Jewish race; the protruding lower lip infers degeneration, and his small sunken eyes connote meanness. So far, however, the description could pass as objective observation, yet the author's bias is conclusively exposed when he moves on to interpret the character's facial expression in terms of rapacity and vulturism. This example is an early illustration of the manipulative technique employed throughout the work, in which language, structure, and overt irruptions on the part of the narrator are used to underline the negative message of the story. The favoured position of the presentation of Don Esteban can be compared, for structural coherence, with the cursory mention of the fact that this ignorant and in all respects handicapped immigrant had amassed an important fortune, and died leaving neither creditors nor debts (p. 27). This fact is not mentioned to add any direct information about Don Esteban himself, but merely as an explanation of how Genaro and his mother could live free from basic financial worries and become involved with dangerous social preoccupations.

The opening chapter is the most important in that it contains the seed of 
all subsequent developments: it sets the tone and it maps out the future. First it establishes the animal-like quality of the protagonist by means of a heavily laden description of the father from whom he is conceived, and then it complements the indictment - for so it appears - by a condemnatory description of the abject surroundings into which Genaro is born.

A further example of the close relationship between structure and content can be found in the exceptional length of Chapter XIII. In a book of forty three short, even chapters, this one stands out for being three times as long as any of the others. It provides a dramatization of the inner conflict that Genaro undergoes before really cheating for the first time in his life. The chapter unfolds in a contrapuntal pattern projecting the debate between the inherited impulse in Genaro, battling for survival at whatever the cost, and the pull exerted by the accepted standards of common decency and morality. The wavering scene is prolonged not as a plausible questioning of the eventual outcome, but as a technical device to make Genaro's fall more significant, and more final in its prediction. After this scene, which puts the seal on the presentation of Genaro, the pace of the novel quickens as if to imply the inevitability of the outcome and events succeed each other rapidly until the final debacle.

In the second part, the setting of the story has moved from the sordid immigrant conventillo to the world of the criollo elíte, but Genaro does not merge into the new surrounding, and stands antithetically apart from it. The meaning of this is that environment can aggravate the effect of inferior racial characteristics, but cannot alter the nature of these. So far, it has been argued that both the plot and its structure are conceived in such a manner as to illustrate and uphold the author's stance against immigration on biological lines. Yet another forceful support for Cambaceres's thesis can be found in his biased presentation of characters in this novel. They fall into the natural division of Immigrants and Criollos; basically, this division is found in all the literature concerned with the problem of immigration, but in En la sangre it takes the form of overt racial discrimination and this is seen as a preoccupation which overrides all other social prejudices. The immigrants remain a massive cohesive block which cannot undergo further ramification, whereas the criollos are a conglomeration of individuals and as such, they respond to a more sophisticated class stratification. The implications of this will be discussed in due course.?

The immigrant characters, for reasons related to the structure of the work and already discussed, appear mainly in the first part of the work. Apart from the odd mention of a midwife here or a porter there, the main Immi- 
gration characters are restricted to the pattern established by Argerich, which consists of father, mother and protagonist son. The rapid mention that is made of background Immigrant characters uses but few words in which to convey an unfavourable impression. For instance, the university porter is dismissed as 'un gallego ñato de nariz y cuadrado de cabeza'. It will be noted that the accusation is levelled at the physical characteristics, something which at first sight might appear as more innocuous than a moral imprecation. Yet within the ideological context of the writing, and bearing in mind the great esteem in which physiognomy was held at the time, it is clear that the implications behind the description relate to the character's low evolutionary status, placing him nearer to the rung of primates than of men. Moreover, being physical characteristics, they are considered immutable, and will be transmitted intact to future generations.

When dealing with the more important Immigration characters, Cambaceres uses subtle means to ridicule and condemn them. The initial physical portrayal of Don Esteban, analyzed a few pages earlier, is supplemented by an accusation that he works and saves, thus illustrating the contention that the prejudice presented in this work echoed the concept that 'pureza de sangre' implied also purity from the taint of manual work. It is the same accusation as was initially levelled at Dagiore, but contrary to the development of Inocentes o culpables, in this work there are no inconsistencies of presentation, and no softening in the attitude of the author. Cambaceres writes: 'consagrado sin cesar, noche y día, a su mezquino tráfico ambulante, con el inquebrantable tesón de la idea fija, continuaba arrastrando el padre una existencia de privaciones y miserias' (pp. 16-17). Don Esteban's role is confined to providing the cause and the explanation for the danger lurking in Genaro, but it is with the latter that resides the central argument against immigration, and its irrefutable proof.

Genaro is an exemplary character, whose principal function is to embody the author's ideas of immigration and to warn off the reader from its dangers. Moreover, he stands out in the literature under review as the most vivid, effective character, and one who justifies the closest attention. This is not meant to imply that he is a rounded figure, but simply that he is, amongst a series of stock figures, the most cogent and the most convincing. Unlike José, whose interest as an Immigrant figure eventually wanes in Inocentes o culpables, Genaro maintans his status as an immigrant throughout the work, and every one of his actions and thoughts is shown to be a manifestation of him in this capacity.

The negative character of Genaro is a pre-requisite of the thesis, and is 
amply borne out by his portrayal: he is physically weak, intellectually inferior, and morally abject. These three attributes are causally linked in a net that is spread horizontally, to everything that happens to him in the present, and also vertically, to everything that has come to him from the past. There is no room for doubt that it will similarly entrap the future. The first description of the protagonist is physical, but as with Don Esteban, this is merely the springboard leading towards a deeper condemnation in which the tendency towards evil is presented as an inherent characteristic.

Así nació, llamáronle Genaro, y haraposo y raquítico, con la marca de la anemia en el semblante, con esa palidez amarillenta de las criaturas mal comidas, creció hasta cumplir cinco años.

De par en par abrióle el padre las puertas un buen día. Había llegado el momento de serle cobrada con réditos su crianza, el pecho escrofuloso de su madre, su ración en el bodrio cotidiano.

Y empezó entonces para Genaro la vida andariega del pilluelo, la existencia errante, sin freno ni control, del muchacho callejero, avezado, hecho desde chico a toda la perversión baja y brutal del medio en que se educa. (p. 15)

The romantic sensibility allied poverty to goodness; in positivistic thought, poverty is a blameworthy characteristic, a sign of 'unfitness' in an evolutionary system in which only the fit are meant to survive. It is interesting to see how this idea permeates Cambaceres's work.

The author's horror of poverty is amply illustrated in the preceding extract by the blame that is implicitly attached to being underfed, suffering from tuberculosis and living in cramped surroundings, yet the sense of accusation varies not only in degree but in kind, according to whether it is directed at immigrants or at criollos. This issue will be dealt with more fully in another context, i.e. the study of metaphors employed, but it may be worth pointing out at this stage the different characteristics which are attributed, on the one hand, to the Immigrant's son and, on the other, to his native-born playmate. Both are subject to the depraved influence of the same conventillo environment, yet Genaro's character is marked as avezado, i.e. sly and treacherous, whereas the mulatto street-urchin is invested with a measure of courage and nobility to which Genaro could never aspire. ${ }^{10}$

Bravo y leal, por otra parte, dispuesto a ser el primero en afrontar el peligro, a dar la cara por uno de los suyos, a no cejar ni aun ante el machete del agente policial, el pardo Andinas ejercía sobre los otros toda la omnipotente influencia de un caudillo, todo el dominio absoluto y ciego de un amo. (pp. 15-16)

It is not difficult to interpret this differentiation: poverty and low birth offend the aesthetic sensibility of Cambaceres; a point which is more fully 
treated in his previous novel Sin rumbo. However, in the apathetic, submissive criollos this does not constitute a threat, whereas in the socially ambitious immigrants it does and must therefore be made the object of the most total denigration. ${ }^{11}$ The aesthetic revulsion caused by poverty is increased in the case of the immigrants by the fear of their seeking to penetrate the higher echelons of society. This hypothesis is amply borne out by the plot of En la sangre.

Genaro's inferiority is declared in absolute terms, with explanations based on racial criteria which are given as unquestionably scientific. The racial theme is repeated throughout, with the recurrence of phrases such as 'del patrimonio de la raza' (p. 37), 'la astucia felina de la raza' (p. 40), 'el ahinco del ciego fanatismo de su casta' (p. 47), and most explicitly in the following:

\begin{abstract}
Y habría querido él no ser así, sin embargo, había intentado cambiar, modificarse, día a día no se cansaba de hacer los más sinceros, los más serios, los más solemnes propósitos de enmienda y de reforma; sí, a la par que de vergüenza, en el hondo sentimiento de desprecio que a sí mismo se inspirara, con las ansias por vivir de quien siente que se ahoga, no había cesado de agitarse, de debatirse desesperado en esa lucha; sí, a todo el ardor de su voluntad, a todo el contingente de su esfuerzo, mil veces había apelado ... inspirarse, retemplarse, redimirse en el ejemplo de lo bueno, de lo puro, de la noble, que en torno suyo veía resistir, sobreponerse a esa ingénita tendencia que lo impulsaba al mal ...

¡Vana tarea! ... Obraba en él con la inmutable fijeza de las eternas leyes, ara fatal, inevitable, como la caída de un cuerpo. como el transcurso del tiempo, estaba en su sangre eso, constitucional, inveterado, le venía de casta como el color de la piel, le había sido transmitido por herencia, de padre a hijo, como de padres a hijos se transmite el virus venenoso de la sífilis ... (p. 61)
\end{abstract}

Thus, the cause for his inferiority is there, permanently lodged in his veins. It is not a moral flaw but a physiological one. Moreover, in the racist context of the time, and in the age of science, this is not seen as a tragic condition, one which might conceivably elicit feelings of pity or sympathy, but as a coolly objective fact which should leave the reader unperturbed were it not for the danger inherent in its propagation. This is precisely the carefully manipulated reaction elicited by En la sangre, since the ideology that held that events take place 'determined by a necessary chain of causation' expresses itself in this work in an appropriately autocratic fashion, in which there is no room for freedom of interpretation. The dogmatism of the ideology is expressed in a dogmatic language which in turn is dogmatic in the response it demands. The response of the reader is carefully determined in a particular direction, and the protagonist's lack of freedom 
in a chain of cause and effect is matched by the reader's lack of freedom in a chain of presentation and response.

The condemnation of Genaro is achieved by means of a skilfully woven narrative strategy which combines the rhetorical techniques described by Wayne C. Booth as 'telling' and 'showing'. ${ }^{12}$ The first consists of direct assertions of an explicit rhetorical nature, such as are found in the descriptions of the protagonist quoted earlier. The second relies on the selectivity of events in the plot which illustrate a point with apparent independence. This device is used mainly in the later stages of the work, when the distance between the narrator and his character has seemingly widened, and the latter appears to move independently. Yet a close analysis of the text reveals that everything in it is always subject to the most careful monitoring on the part of the author.

The novel in its entirety combines to discredit Genaro, and there are two voices who speak out uppermost in this task, the one belonging to the narrator and the other to the protagonist himself. The narrator assumes a typically traditional omniscient stance: not only does he know everything, but he is reliable in the sense that he does not have recourse to irony, and his judgements are infallible. He aligns the reader next to him and forces him to share his viewpoint. Any of the extracts quoted hitherto offer an illustration of this point.

The second voice used in this veritable crusade against immigration is Genaro's himself. Normally, and particularly at first, he too aligns himself with the narrator and the reader, sharing in their concerted awareness of his inferiority. An incident which takes place early in the novel shows the combined effort of plot, narrator and protagonist in propagating the central thesis of the novel. It occurs when the young Genrao, unmindful of the burden of his past, and attempting to overcome his own insecurity, makes friends with a jovial group of criollo students who seem to have accepted him with a certain degree of good nature. The outside world, however, proves to be as contaminated by the effect of his inheritance as he is himself, for inevitably, while on a prank with his friends, he meets an old inmate of the conventillo who knew of his wretched childhood and who relates the fact loudly, for all to hear. The man greets him enthusiastically, shouting '¿Che, tachero, cómo estás, cómo te va? iPucha que has pelechau, ${ }^{13}$ hombre, que andás paquete!' (p. 36). Needless to say, the story is avidly received by Genaro's friends, who from then on insist on calling him by the nickname of tachero. The incident is significant in showing that no escape is possible, that he will always be recognized as the son of his father, the tinker and that any 'changes' which he undergoes can only be 
superficial. Furthermore, it serves as motivation for the mixture of hatred and envy which from that moment onwards underlies all Genaro's actions.

Genaro's reaction to this situation is recorded in three different stages. At first the narrator adopts an impassive position, as if letting events show their point by themselves; and yet by virtue of this apparent objectivity, it is clear that he tacitly endorses Genaro's reaction of guilt and shame in a way which invites the reader to agree with the appositeness of these sentiments:

Fue un colmo. Encendido el rostro de vergüenza, esquiva la mirada, balbuciente, sin atreverse a huir de allí, sufriendo horriblemente con quedarse como un criminal, sorprendido en el acto de delinquir, viose Genaro obligado a soportar hasta el fin aquel suplicio. (p. 36)

This is followed, closely on, by the narrator's own commentary. He is clearly telling the reader about the effect that the evil that was transmitted to Genaro has upon him. His views are aired with the certainty of scientific data:

Y víctima de las sugestiones imperiosas de la sangre, de la irresistible influencia hereditaria, del patrimonio de la raza que fatalmente con la vida, al ver la luz, le fuera transmitido, las malas, las bajas pasiones de la humanidad, hicieron de de pronto explosión en su alma. (p. 37).

Without any halt in the flow of the narrative, almost imperceptibly, the voice of the narrator give place to that of the protagonist, who echoes the sentiments expressed hitherto with the added emotional impact of a strongly subjective language. Thus, the passage continues:

¿Por qué el desdén al nombre de su padre recaía sobre él, por qué había sido arrojado al mundo marcado de antemano por el dedo de la fatalidad, condenado a ser menos que los demás, nacido de un ente despreciable, de un napolitano degradado y ruin? (p. 37)

Total harmony exists between narrative, narrator, protagonist and reader, all sahring in the same ideology. As the story unfolds, however, Genaro appears to move away from this harmonious circle and to rebel against a belief in the unquestionable superiority of criollo society and a perennial position of humble admiration and respect. This change is perceptible in the register of the language in which Genaro's thoughts are given. At first, Genaro is totally overawed by the manifest superiority of the criollos surrounding him. Yet later on, the vantage point from which he considers 
them has changed, as shown by the coarseness with which the thinks of Máxima at the end of the following lines:

¿Qué se había figurado la muy cangalla, que iba a poder ponerlo como un trapo, como un suelo, así, así sin más ni más? iYa vería si se había de jugar con él, si era hombre él de dejarse manosear impunemente por una mocosa como ella! (p. 140)

These outbursts are usually short and well highlighted by the narrative as examples of the mean nature of Genaro's thoughts. Their aim is not to cast any doubt as to the qualities of those against whom they are directed but to condemn Genaro even further for his baseness of thought. The reason why Genaro may indulge in these short outbursts is that after the initial chapters, his character has been discredited with such finality that it only remains for the narrator and the reader to observe him from above and follow his destruction. Anything that he may do or say can have the only possible effect of giving further proof of his complete unworthiness. There is one instance, however, in which the narrator himself joins Genaro in a prolonged passage of invective aganst the criollo élite, as if in direct contradiction with the overall design of the work. It occurs after Genaro has been refused entry to the socially exclusive Club del Progreso, and he gives vent to the following feelings of spite and rage:

¿Quien los veía, quién los oía a ellos, a todos ..., de dónde procedían, de dónde habían salido, quiénes habían sido, su casta, sus abuelos ..., gauchos brutos, baguales, criados con la pata en el suelo, bastardos de india con olor a potro y de gallego con olor a mugre, aventureros, advenedizos, perdularios, sin Dios ni ley, oficio ni beneficio, de esos que mandaba la España por barcadas, que arrojaba por montones a la cloaca de sus colonias; mercachifles sus padres, tenderos mantenidos a chorizo asado en el brasero de la trastienda y a mate amargo cebado atrás del mostrador; tenderos, mercachifles ellos mismos!... iY blasonaban de grandes después y pretendían darse humos, la echaban de hidalgos, de nobleza, se ponían cola en el nombre, se firmaban de, hablaban de sus familias, querían ser categoría, aristocracia y lo miraban por encima del hombro y le tiraban con el barro de su desprecio al rostro! ...

Aristocracia ..., ique trazas, qué figuras esas para aristocracia, aquídonde todos se conocían! ... (pp. 82-3)

The narrator had forewarned the reader that what is about to follow is the result of envy, frustration, and hatred, yet the passage makes its impact nevertheless, first by virtue of its length, and secondly because of the quality of the prose, which in terms of rhythm, imagery and rhetorical vigour goes much beyond the usual function of merely discrediting Genaro in the end taking the reader along the path of the abuse. It is clear 
that this is aimed at certain sectors of the criollo elite, and similarly it is clear that the narrator has taken over at some imperceptible point to voice prejudices which are his own. This is witnessed by the racialist tone of the diatribe in which historical provenance is the predominant preoccupation, and also by the social prejudices against commerce and manual work. Thus, in line with the nature of prejudice outlined at the beginning of this study, the criollos are derided first for their gallego and Indian origins, and secondly for the menial occupations of their ancestors. The invective is consistent with the hierarchical nature of Cambaceres's racialist prejudices which place his own British and French provenance above anything Spanish, to say nothing of Indian. Moreover, Cambaceres was intimately connected with the Club del Progreso, having been elected Secretary of the Club in 1870 and Vice-President in 1873 . His peroration, therefore, is most likely directed at those who might underservedly wish to intrude into the closed ranks of the élite, and therefore, instead of being aimed against the real élite it could be said to be there to defend their privileged position.

The ills of immigration are illustrated almost exclusively through the bad example offered by Genaro but there is one brief mention of immigration as a positive force, when Genaro defends his faith in the country's progress because of continuing immigration:

Nada justificaba, no había razón para que habiendo valido hasta entonces, de la noche a la mañana, se viniera barranca abajo y dejase de valer la tierra. iPor qué? Cien mil inmigrantes desembarcaban por año, el país se iba a las nubes, marchaba viento en popa ... (p. 126)

The strong sarcasm contained in the passage become immediately apparent when placed against the context of the plot. Genaro loses his fortune as a consequence of investments made because of his faith in Immigration policies. To the reader of a few years later, the link between these pages and the financially ruinous Baring Crisis $^{15}$ would be an easy, almost automatic step.

The depiction of one set of characters in a novel must be closely linked to that of any other set. In spite of the social integration that takes place at the level of the plot, the social world of En la sangre is polarized between the Immigrants and the Criollos. As mentioned earlier, the first form one cohesive group which remains essentially unaffected by any changes the immigrant may undergo. The criollos, on the other hand, are seen as a more heterogeneous group, in which class is an important dividing factor. Race too has some part to play in the hierarchical presentation of criollos, 
for the greater the Indian component, the lower down the scale will the character be placed, but, because the Indians do not pose the same kind of threat as the immigrants, they are not viewed as deprecatingly as the Italians who, in this work, as in the previous, are symbolic of all the poor immigration arriving in Argentina.

With respect to the criollo, three main divisions are evident. Lowest down the scale are what Cambaceres terms the 'mulatos', a term which perhaps should not be taken too literally as referring to a Negro ancestry, but accepted as a synonym of 'mestizo'. This group is the least threatening to the élite, and is accordingly referred to with a mixture of contempt and patronizing endearment. The difference between the young Genaro and his dark gang leader has already been pointed out; in another context the author talks of 'alguna mulata zaparrastrosa, desgreñada', showing his revulsion at the level of the girl's appearance. Again, it is dress and appearance which are the butt of the author's comments on the lower middle class staff at Genaro's school, but there is a noticeable increase in the level of invective running parallel almost with social ascension. Thus the school secretary is ridiculed as 'bajo, grueso, rechoncho y como por error metido en una levita negra ...' (p. 30). One of the teachers is viewed with similar distaste: 'precisamente atinaba a pasar el profesor de primer año, un hijo del país, zambo, picado de viruela y vestido de levita color plomo' (p. 30). Finally, the most strongly worded diatribe against the criollos, it will be recalled, was directed at the would-be élite of the Club del Progreso.

The genuine élite, however, is considered admirable in every respect and their innate superiority is obvious to the point that it hardly needs to be mentioned. This is something that Genaro understood well when he first had to compete at University. Comparing his lack of intellectual ability with the effortless superiority of his native colleagues he says:

Pero era que brillaba en sus frentes la luz de la inteligencia, qué podían ellos, qué sabían, qué comprendían, que el solo privilegio del ingenio bastaba a emanciparlos de toda ímproba labor ..., mientras él ... iOh, él! ... (p. 42)

The contrast is clear: Genaro is gnawed within, darkly, surreptitiously by his 'ingénitas tendencias', whereas they carry their worth as an outward, shining torch. Yet the most interesting idea of the passage is expressed by 'improba labor' illustrating once more the extent to which work was considered to be degrading if even intellectual effort was included in this censure. $^{16}$

The criollo family which constitutes an idealized point of contrast with 
Genaro's wretched family is marked by its idleness. It has what in the ideological context of this work constitutes the highest form of wealth, i.e. inherited landed wealth. It is interesting to note that whereas in the context of immigration heredity is a physical, biological phenomenon, in connection with the élite it is economic inheritance which becomes the predominant preoccupation. They inherit good looks, intelligence, the right code of behaviour, but above all they inherit money. The latter is seen not as an objective material acquisition but as the sacred, symbolic perpetuation of a moral attribute. Thus, Máxima's concern for preserving her son's patrimony is expressed in hushed terms of reverence:

Es cierto, no paso de ser una pobre muchacha ignorante yo; pero una cosa sé, sin embargo, es que soy madre, que pesan, en tal carácter, deberes sagrados sobre mí y que eso me basta.

Lo que he recibido de mi padre, quiero dejárselo a mi hijo, es suyo, le pertenece, permíteme que te recuerde que estamos tú y yo en la obligación de conservar y trasmitirle intacto el patrimonio que le viene de su abuelo. (p. 130).

Máxima's family too is formed by a triangular relationship in which the parents are present mainly as an illustration of the theory of causality. ${ }^{17}$ The strongest influence is that of the father, who in this case is almost the exact opposite of Don Esteban. He is elegant, self-assured, as is apparent from his masterful treatment of Genaro, to whom he says:

-Sírvase evitarme la molestia inútil de escucharlo -prosiguió-, solo a efecto de hacerle conocer mis órdenes, es que se encuentra usted aquí, y entiendo que sean ellas al pie de la letra ejecutadas, sin observaciones de su parte y sin que absolutamente por la mía, tenga en cuenta ni me importe lo que usted piense, quiera o diga. (p. 107)

(cf. Don Esteban's words, which are confined to utterances such as '¿Sta inferma vos?' p. 14).

His own provenance is, of course, impeccable:

... un hombre rico, dueño de muchas leguas de campo y de muchos miles de vacas, poseedor de una de esas fortunas de viejo cuño, donación de algún virrey o algún abuelo, confisacado por Rosas, ...

To have been the victim of Rosas's Federalist policies was considered in itself a mark of social prestige. Thus, this last point, implying that he belonged to the Unitario party, completes the image of highborn urbanity. Máxima carries her position in her name but she is the least well drawn character in the novel. Her portrayal contains a measure of ambiguity in that it suggests both slender refinement, and full-blooded sensuality: 
Era morena y muy linda; a la vez que llena de formas, delgada y fina; como una luz de esmalte negro, brillaba, se desprendía en hoscos reflejos de la órbita ojerosa de sus ojos, y, mientras revelando un intenso poder de sentimiento, su nariz afilada, ancha de fosas, se dilataba, nerviosamente por instantes se contraía bajo la impresión melódica del sonido o la atracción del juego escénico, en su boca de labios gruesos y rojos, todo el calor, todo el ardiente fuego de la sangre criolla se acusaba. (p. 68)

This description is symptomatic of an acute identity crisis which the criollo élite was undergoing at that time. Máxima is not Amalia. Whereas it was easy for Mármol to have depicted, in the mid-century, heroines who were replicas of European romantic figures, by the end of the century, and in the light of immigration, European values were no longer considered the sole criterion of desirability, and Cambaceres was forced to tread a careful line between the two cultures. Thus he could not create an elegantly, insipid, languid heroine, nor could he overindulge his implications of sensuality. He strikes a balance with the control of 'delgada y fina' and 'labios gruesos y rojos'.

Máxima's part in the plot is not convincing. The fact that she succumbed not once, but repeatedly, to Genaro's advances and seductive efforts is traced back, in this work of causal connection, to an upbringing with dolls, and to the fact that all her friends had 'novios'. The reason for this dramatically weak explanation is that as a member of the élite she is always given the benefit of any doubt, and only innocent and pure motives are ascribed to her. Her actions are never examined with the same cold logic as are Genaro's. Further on in the story, she displays a similar ambiguity in that she assumes the stereotyped role of passive mother-figure, who has given up the world, and yet retains sufficient shrewdness and business acumen to detect her husband's fraudulent transactions.

Máxima's role in the novel grows progressively, but it is always allied to that of Genaro, who remains throughout the central preoccupation of the work. One of her most important functions is to provide a point of excellence against which Genaro can be judged and duly denigrated.

The social divisions of the characters in the novel are supported linguistically. One specific type of metaphor has been chosen to test this view, viz animal metaphors which, given their extensive use in all works under the influence of Zolian Naturalism, were thought to be the most fruitful source for an investigation of this kind. The list of animals used as images for different characters is as follows:

$\begin{array}{llll}\text { águilas } & \text { buey } & \text { gusano } & \text { pavo } \\ \text { animal desbocado } & \text { buitre } & \text { lobo } & \text { perdiz }\end{array}$




$\begin{array}{llll}\text { animal sarnoso } & \text { culebra } & \text { marranos } & \text { perro } \\ \text { bagual } & \text { fiera } & \text { moscas } & \text { potro } \\ \text { bestia } & \text { gato } & \text { murciélago } & \text { reptiles } \\ \text { bicho } & \text { gallo alzado } & \text { pava } & \text { zángano }\end{array}$

There are forty-three examples in eight-seven pages. The average occurrence should be one animal every other page, but the graph is not even. Instead, there are five animals in as many pages at the beginning when presenting Genaro and his family, and an equally high proportion at the end, when Genaro is shown finally to succumb to the bestiality of his inheritance.

The narrator uses the first nineteen images (there is one exception) directly in the first part of the book, i.e. the part that deals mainly with the immigrants and their racial characteristics. As from page 62, roughly half the images are used by Genaro in his thoughts. This bifurcation reflects a certain slackening in the overt rhetoricism which has already been noted, and confirms a shift in the manner of presentation. The protagonist is made to illustrate the narrator's condemnation of him by his actions and by his thoughts. There are some basic differences in the characteristics of the animals used, and in the impression that any comparison with them will convey. Some obvious groupings emerge, such as flying animals and crawling animals.

I FLYING ANIMALS

Buitre: $\quad$ used to reinforce a statement about Esteban's rapacity

$\begin{array}{ll}\text { Murciélagos: } & \text { (p. 13) } \\ & \text { referring to Genaro and his street-urchin friends in an }\end{array}$ imitation of a sexual orgy (p. 16)

'Bicho que volara': a fellow student of Genaro (p. 49); also referring to Genaro (p. 69)

Moscas used by Genaro about his friends whom he envies and Zánganos mistrusts (pp. 122-3)

Aguilas: used by the narrator to refer to the other university students who stand out in marked contrast to Genaro. The comparison is worth quoting in full: ... 'se sofocaba, porque el aire le faltaba en aquella atmósfera elevada y pura, como falta a los reptiles donde se ciernen las águilas'.

(p. 60)

There is a definite qualitative progression within this group, ranging from the vulgar buitre, with its medieval association of usury, to águilas, the princes of the skies. Metaphors of flying animals are counterbalanced by 
those of crawling animals. It is not surprising to find that these relate mainly to the Immigrant characters.

\section{CRAWLING ANIMALS}
Reptiles: $\quad$ see above quotation
Gusano: $\quad$ Genaro about himself (p. 67)
Culebra: $\quad$ narrator about Genaro (p. 86)
Viboras: Genaro on himself, comparing his racial inheritance with the venomous tooth of the viper (p. 139)

The conclusion is only too apparent: every animal in this category refers to Genaro. Similarly, the word arrastrarse, so evocative of crawling animals, is one that recurs frequently, and always refers to the Immigrants. The remaining animal metaphors lend themselves to the following division: domestic animals and wild animals.

\section{DOMESTIC ANIMALS}

Animal sarnoso:

Pava:

Pavo:

Marrano:
Genaro referring to himself (p. 122) used by Genaro about Máxima and repeated three times (p. 132)

Genaro thinking about himself, as a contrast to Máxima's other suitors whom he calls gallo alzado (p. 72) (see under 'Wild Animals') Genaro on his son (p. 122)

Certain animals recur with varying frequency, shaded by their context:

Gato:

a) 'gato que se encrespa y manotea al solo amago de verse arrebatar la presa': Esteban (p. 18)

b) 'la astucia felina de su raza': Genaro (p. 42)

c) 'en un brusco manotón de gato hambriento alargó de instinto el brazo': Genaro (p. 118)

Bucy: $\quad$ it is used three times with different connotations

a) 'una resignación de buey': referring to Esteban in connection with his attitude to work. (p. 13)

b) 'un tesón de buey': referring to Genaro's unintelligent perseverance of his studies (p. 39)

c) 'los bueyes con que araba': used quite differently by Genaro in his thoughts about Máxima’s family (p. 93)

Bestia:

a) 'bestia acorralada': used in reference to Genaro (p. 38)

b) 'bestia puesta a dieta': referring to Genaro and his friends (p. 56)

c) 'bestia de carga': Genaro contemplating his life as a student (p. 62)

d) 'bestia - hombre convertido en bestia -' is Máxima's growing impression of her husband (p. 110) 
a), c) and d) are beasts of burden, whereas b) is different: a beast because unsophisticated, not risen in evolutionary terms, but with certain connotations of the noble savage. The difference reflecting the basic division that separates Immigrants and Criollos, is illustrated more fully by the use of the word fiera in the next grouping.

Perros:

a) 'perros sin dueño, que merodean de puerta en puerta en las basuras de las casas': a wretched animal used to describe Esteban's itinerant work (p. 17)

b) 'perros atados': wild schoolboys, restrained by the presence of the beadle (p. 32)

c) 'perros ratoneros': Genaro's colleagues (p. 58)

d) 'perro': Genaro in his thoughts about Máxima's opinion on him (p. 82 and p. 137)

e) 'perros a las osamentas': referring to Genaro's instinct of self-preservation (p. 140)

Once more there is a marked difference between the use of perro denoting the lowly cur, as used for the Immigrants, and the wild hound, as used to qualify the Criollos.

$\left.\begin{array}{ll}\text { Caballo: } & \text { is used for Genaro (p. 106), whereas: } \\ \text { Baguales } \\ \text { Potro }\end{array}\right\} \quad \begin{aligned} & \text { are used by Genaro in his outburst against the upper } \\ & \text { classes (p. 82) }\end{aligned}$

IV WILD OR UNTAMED ANIMALS

Fiera:

a) 'fieras enjauladas': used in reference to the schoolchildren (p. 31)

b) 'fiera': the crowd who came out of the Colón (p. 95)

The term is ambiguous: una fiera is a low species in evolutionary terms but wildness carries with it a connotation of freedom, bravery and nobility.

León: the exclusive Club del Progeso is so evaluated by Genaro

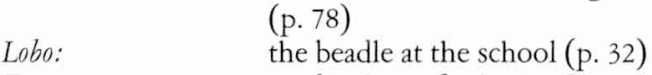

Zorro: $\quad$ used twice, referring to Genaro's shrewdness and cunning, which are presented as despicable qualities (p. 53 and p. 63)

'Gallo alzado': $\quad$ in Genaro's thoughts, Máxima's other suitors (p. 72) 'Animal desbocado que corre a estrellarse contra un muro':

the author's comparison with Genaro again stresses not the independence of the animal but his blind stupidity and therefore could genuinely be slotted into the domestic animals group (p. 135)

Perdiz: although it refers to Genaro, it is used by his fellow students (p. 58) 
To summarize the foregoing, it can be said that the initial polarization between Immigrants and Criollos is sustained at the level of imagery. There exists a marked difference in the qualities attributable to either side, and although there may be subtle variations within each side, the overall pattern is not affected.

On the side of the Immigrants there is a difference of gradation rather than kind between the images that emerge from the two main characters affected:

- Don Esteban is condemned on two contradictory fronts: for his rapacity and avarice, and for his bestial stupidity;

- Genaro is somewhat different. He no longer needs to be rapacious; his ambition stems from the envy and hatred of insecurity.

Thus buey is used for father and son, but more passively in 'una resignación de buey' referring to Esteban, than in 'tesón de buey', referring to Genaro. There is a wider range of animals related to Genaro, and although his bestiality is stressed repeatedly, he oscillates between the lowly crawling species to something more developed, such as a fox. Thus, Esteban the cat is blindly aggressive, while Genaro is likened to a hungry tomcat. Also, he is motivated by something more refined in his 'astucia felina'. In accordance with what has been noted about the relationship between narrator and protagonist, there is no appreciable difference in the images used by them. The second group of characters in this connection comprises the native Argentines. The élite are spared any direct observation. Even Genaro allows himself to use only very mild terms in his thoughts about them or what they may think about him, using words such as pava, perro, bicho. As for the lower echelons of criollo society, Cambaceres reveals no little distaste for them, and uses a fair number of animal images to describe them. These will be found either in the flying or wild animal groupings, but not in the domestic or crawling group, thus underlining the essential difference between them and the Immigrants. They may be wild and uncivilized at worst, but they are neither stupid, nor grabbing, nor sly. Thus it can be seen that the use of animal metaphors in En la sangre upholds the argument expressed earlier that the central and overriding purpose of this work is to denigrate and condemn the immigrants in a way which transcends a condemnation based on reasons of class, such as is found in Cambaceres's other works. It is true that Cambaceres's aesthetic sensibility is drawn towards an exaltation of the criollo élite, showing an indisputable disgust for the lower classes, but overriding this division lies the central theme of the work, which is concerned with eradicating, in as final a manner as possible, the urgently felt threat posed by immigration. 
There is one final point which, in the light of existing literary criticism, ought not to be left unstudied. This concerns the many claims that continue to be made regarding the realistic nature of the novel under review. The three comments which follow were all made in recent years.

O. Blasi Brambilla writes in Los Fundadores: 18 'También logra, y no es su menor mérito, una vívida reconstrucción de lugares, tipos y costumbres bonaerenses'. In his introduction to Cambaceres's Obras Completas, E. S. Danero declares En la sangre:

... novela, sin duda alguna en la que aplica con rigor científico la fórmula del naturalismo ...

La imprenta que sobre cierto estrato de nuestra sociedad deja Cambaceres no es de las que se borran. Y hasta corresponde añadir que de esos tipos parásitos, de los incontables Genaros que hemos tenido y padecido, provienen también no pocas de nuestras calamidades económicas, sociales y políticas y hasta culturales. Una advertencia aunque no literalmente consignada, dejó Cambaceres palpitante al final de su novela: 'CCuidado! Muchos Genaros te aguardan, lector, lectora, al doblar las esquinas porteñas' ...

Es uno de los puntales de nuestra cultura literaria. Fue íntegro en su obra y limpio en sus procedimientos artísticos. ${ }^{19}$

Finally, Teresita Frugoni de Fritzsche notes the agility of Cambaceres's use of language remarking both on the fine ear with which he records conversation, and the distant impassivity of his narrative: 'En ciertos momentos narrativos se vale de oraciones comenzadas con era o eran, con el deseo de acentuar la impersonalidad del relato y evitar todo parcialismo'. ${ }^{20}$ These observations suggest that the work has a certain documentary value in its depiction of the background, and stress the objectivity of the recorder, Cambaceres, with regard to his work.

It is true that En la sangre is set in a recognizable Buenos Aires but very little valuable information about everyday reality is included, for things are either mentioned briefly, in passing, or to make a specific point, in which case they are suspiciously distorted in order to serve the interests of the story. Much is made of the documentary value of life in the conventillo, but upon closer study, it is found that it presents a typical picture of coarseness and overcrowding, with no true insight as to the feel of the tensions or deprivations of the place. ${ }^{21}$

The novel is also said to offer a portrayal of the life of immigrants, yet no essential details about them are given. There is no factual information about the conditions and opportunities open to Immigrants as witness the total silence, already noted, about Esteban's acquisition of a fortune. Regarding the objectivity of the narrative, the present study has already 
drawn attention to the various manipulative techniques employed with ability and consistency by the author.

And yet, the truth of fiction lies not in its mimetic efforts, but in the insight that it gives, by whatever means, of the society it describes. It is, therefore, not in the depiction of reality that the ultimate message of En la sangre should be sought, for this, as shown, is totally distorted by the strong prejudices which inspired the writer. Indeed, the truth of this particular fiction is lodged precisely in the prejudices underlying the work and in the insight that it offers of the extent of hatred and fear that Immigration was arousing in Argentina. A testimony of this is not only the novel itself, but its unquestioned acceptance as a work of Realism by a wide and by no means unsophisticated reading public.

The thesis that was so forcefully announced by Argerich in his Prologue, and so inconsistently developed in his own novel, is argued in En la sangre rigorously, with unrelenting ardour and with great persuasion. In this work, the portrayal of Immigrant characters is of an extremely negative nature, since immigrants are not simply presented as inferior but as an inherently and immutably different species, with no possible hope of redemption. 
No study of the literature of Argentina at the close of the nineteenth century would be complete without an examination of La Bolsa, one of the most influential works to have been written at the time. Its success was immediate; moreover, it has lasted to the present, as witness the fact that the novel has had several re-issues, and has been the object of repeated and renewed critical interest. ${ }^{1}$ This is due not so much to a question of literary merit, though this is not entirely absent, as to the insight that the work affords into the rising tension affecting society during the crucial decade of 1880-1890. Its author, Julián Martel (pseudonym for José Miró) was a young journalist who worked for the country's leading newspaper, $\mathrm{La}$ Nación, where La Bolsa first appeared in serial form, from 27 August to 7 October 1891.

Martel, of Basque origin though born in Buenos Aires, was a member of the impoverished branch of a wealthy family, and one of the first professional writers in Argentina. According to Ricardo Rojas, the young journalist and writer had to keep himself and his mother out of his earnings, ${ }^{2}$ a situation which is reflected in one of the characters in the novel. A further autobiographical link exists in that Martel was himself a victim of the Stock Exchange. These details are interesting because of the way in which they are portrayed in the novel, where both work and financial transactions are frowned upon. Work, even a journalist's work, is considered a less than honourable pursuit, in that it presupposes involvement in a selfinterested, materialistic effort. Similarly, any commercially based transaction is considered demeaning, the ideal being inherited wealth.

Martel did not rank with the moneyed, landowning élite of which Argerich and Cambaceres were prominent members, yet it is to be noted that he does not acknowledge his own interests, which would be those of a rising middle class, but favours those of the traditional landowning group. He surpasses both Argerich and Cambaceres in his zeal against change, under which the position of the landed élite, while enhanced economically, might be threatened from other directions, both political and cultural. The young inexperienced idealist had obviously underestimated the ability of the élite to adapt and diversify, and fought to check the tide of change. La Bolsa does not stop at its attack on Immigration, but con- 
stitutes a loud, explicit condemnation of the whole materialistic ethos which lay behind the advent of immigration. Its target is the liberal policy in its entirety, with its desire for closer integration with Europe, its pursuit of economic progress, and its encouragement of social mobility, all of which Martel repudiated.

Undoubtedly, grounds existed for Martel's misgivings. Economically, the spectacular growth witnessed during the decade of the eighties had acquired a momentum that could not be maintained. In the end investment was directed more to speculation than to production, and the slightest tremor was sufficient to upset a very delicately balanced economic structure. Inevitably, this occurred, creating the Baring Crisis of $1890 .{ }^{3}$ The shock to the country was severe and called for a moment of re-appraisal. On the political front, corruption was exposed and the President of the Republic, Juarez Celman, was made to step down. The economy, however, soon recovered its buoyancy, and politically the country reverted to its previous policies. But a deeper awareness of the superficiality and vulnerability of the age can be detected in the contemporary literature. The impending crisis became the subject of a series of novel known as El ciclo de la Bolsa, ${ }^{4}$ of which Martel's is virtually the only one that remains known. ${ }^{5}$ Fraud, corruption, venality, became legitimate themes for any socially aware writer, and indeed they can be found almost as standard ingredients in any realistic novel of the time. ${ }^{6}$ In La Bolsa these themes are related to the immigrants. Their depiction can be termed metonymic, in that it ascribes to the effect, the properties of the cause. Thus, it is the immigrants, with their alleged lust for financial gain, who are blamed for imparting a spirit of materialism to a hitherto spiritually pristine society whereas any objective appraisal of the events must surely recognize that it was an already highly developed materialistic drive which instigated the economic programme needing Immigration for its fulfilment and success. To point out that Immigration was not motivated by altruistic, humanitarian reasons, but as part of a project which would benefit first and foremost the interest of its propagators, may sound platitudinous today, with the cooling perspective of hindsight, but it certainly was not generally appreciated in that light by its contemporaries, as shown in all the literature under review.

La Bolsa is perhaps the extreme example of this sort of inverted representation of events. It is also the most fundamental, the most far-reaching in its attack on Immigration, which is blamed not only as an evil in itself, but is held responsible for causing and spreading evil to the whole of society. All immigrants are condemned in La Bolsa, but one people, the Jews, are 
singled out as the worst culprits of the ills that have befallen Argentina, and presented as a powerfully dangerous and sinister force. Within Martel's xenophobia, there is a vein of hyterical anti-semitism. ${ }^{\text {? }}$

Before proceeding to a direct analysis of the text it may be useful to consider the full implications of the concept of 'la inmigración' in La Bolsa. Immigration, in its broadest sense, occurred in Argentina in a plurality of forms, ranging from stock-cattle, investment capital, technical and entrepreneurial skill, to that of the labour force itself. Martel's work stands out for treating the problem in its widest context, dealing with changes which stemmed from the process as a whole and by perceiving the links which existed among these disparate elements. It is a great shortcoming of Martel's work that, having conceived the problem in its depth, its author should have clouded his arguments with a moralizing tone, and relied on unchecked prejudice rather than on objective judgement. Moreover, his arguments remain sterile, theoretical pronouncements, unsubstantiated by the main action of the story, and causing a conflict between the fictional content and the ideological commitment of the work. These two aspects will be studied separately. First, the presentation of characters will be examined both from information acquired through the narrator's direct observations and from the character's own behaviour. This will then be viewed against the more general background of ideas which are expressed in numerous pronouncements throughout the work.

The plot is centred around the rise and downfall of the figure of Dr Glow, a young, respected lawyer who is enticed away from his profession by the reigning temptress of the day, 'la Bolsa'. A confusion of codes can be detected here. First, there is the social code denoted by 'the respected lawyer'; then, there is the economic code implied in the financial aspect of 'la Bolsa', and lastly there is the moral code with overtones of the supernatural, encapsulated in the word 'temptress'. This confusion persists, and the story oscillates between a realistically set plane in which Dr Glow and his associates move amidst the growing opulence of the thriving capital, participating in and inventing the most daring financial schemes, and the moral plane in which these events are continually interpreted. Indeed, 'la Bolsa', a financial institution - the epitome of capitalist economy - is allegorized in this work as a female deity with an irresistible, malevolent grasp, which is all embracing and engulfing. Yet this monster is but the final, outward manifestation of a dark and sinister force which is traced back to Immigration and its perverting ways.

The presentation of the characters in La Bolsa offers a clear illustration of the fundamental lack of coherence which predominates in this work. 
Their descriptions in most parts are not borne out by the actions they are called upon to perform but are left as examples of prejudice. The same polarization between immigrant and criollo characters observed in previous works, can be found in La Bolsa, and the argument can still be maintained that both groups are observed from a basically different viewpoint, with a priori disapproval for the one, and much leniency for the other. But the immigrant characters do not constitute the central, focal point of interest of this work which, as stated above, is directed mainly at the changed atmosphere which the immigrants are said to have brought about. The immigrant characters themselves, abstractions made out of prejudices, fall into two categories: the first are the background figures of abject poverty, street vendors, beggars, crippled wretches who clutter up the streets of Buenos Aires; the other are the adventurers, financiers, and bankers who have come to exploit and contaminate the native population. The first signs of a new attitude towards Immigration can be perceived in the narrator's remarks introducing the subject. The immigrants are no longer ridiculed or blamed for their voracious capacity for work; instead the facts are distorted in the opposite direction, and Martel fails to acknowledge that it was immigrant labour that was overwhelmingly responsible for developing the potentialities of the country and creating vast riches for its ruling class. Thus Martel talks of 'esos parásitos de nuestra riqueza que la inmigración trae a nuestras playas desde las comarcas más $\operatorname{remotas}^{\prime}$ (p. 8). ${ }^{8}$

This assertion is followed by a highly coloured description of the immigrant poor. The language of Naturalism is easily detected in the lingering gaze upon the repugnant, the deformed, the outcast, but as with Cambaceres, the emphasis placed upon these social calamities is completely the opposite from that which motivated Zolaesque Naturalism. Here these human wretches are not looked upon with pity or understanding, but are insidiously blamed for their misery:

Turcos mugrientos, con sus feces rojos y sus babuchas astrosas, sus caras impávidas y sus cargamentos de vistosas baratijas; vendedores de oleografías groseramente coloreadas; charlatanes ambulantes que se habían visto obligados a desarmar sus escaparates portátiles pero que no por eso dejaban de endilgar sus discursos estrambóticos a los holgazanes y bobalicones que soportaban pacientemente la lluvia con tal de oír hacer la apología de la maravillosa tinta simpática o la de la pasta para pegar cristales; mendigos que estiraban sus manos mutiladas o mostraban las fístulas repugnantes de sus piernas sin movimiento, para excitar la pública conmiseración; bohemias idiotas, hermosísimas algunas, andrajosas todas, todas rotosas y desgreñadas, llevando muchas de ellas en brazos niños lívidos, helados, moribundos, 
aletargados por la acción de narcóticos criminalmente suministrados, y a cuya vista nacía la duda de quién sería más repugnante y monstruosa: si la madre embrutecida que a tales medios recurría para obtener una limosna del que pasaba, o la autoridad que miraba indiferente, por inepcia o descuido, aquel cuadro de la miseria más horrible, de esa miseria que recurre al crimen para remediarse ... (pp. 8-9)

Furthermore, none of their lives will be followed in the novel. This picture of expressionistic horror could have had little factual basis since the ill and the deformed were not allowed into the country, and its only possible purpose in the work is to create at the very outset, an unfavourable impression regarding massive immigration. This having been achieved, the author then moves on to condemn Immigration in its wider context.

The main body of immigrants is formed, not as in other novels, around the poor labourer who rises from rags to riches, but by the adventurers and entrepreneurs, who strictly speaking do not fit the category of immigrants, but who are included because Martel views them and their commercial practices as part of the process of Immigration. In short, he equates Immigration with cosmopolitanism and with materialism, and curses the phenomenon in its entirety. The building of 'la Bolsa' itself is seen with manifest disapproval as a resurgent Tower of Babel:

Promiscuidad de tipos y promiscuidad de idiomas. Aquí los sonidos ásperos como escupitajos del alemán, mezclándose impíamente a las dulces notas de la lengua italiana; allí los acentos viriles del inglés haciendo dúo con los chisporroteos maliciosos de la terminología criolla; del otro lado las monerías y suavidades del francés, respondiendo al ceceo susurrante de la rancia pronunciación española. (p. 13)

Yet when it comes to individual characters in the novel, there is not a great number of immigrants, and in some cases, although much evidence would suggest a foreign extraction, this is not considered important enough for it to be mentioned. A case in point would be that of Zole, whose name and occupation as a construction engineer are a hint that he belonged to the small but important skilled middle class immigration that went to Argentina. His origin is not mentioned, but the character is ridiculed for his mathematical, that is to say, practical bent. The abuse of the concept of physiognomy adds a touch of humour to the following description: 'Era un hombrachón muy feo, narigón, flaco, zanquilargo, de cabeza cuadrada, matemática, que a todas las cuestiones, especialmente a las artísticas, pretendía resolverlas por el método de eliminación' (pp. 12-13). Those characters who are specified as immigrant form a small but socially heterogeneous group. They range from servants to bankers, but they all 
have in common opportunism and a materialistic outlock which is obviously to be condemned. The English coachman, 'enfundado en su blanco capote de goma, que le daba el aspecto de un hombre de mármol' (p. 9), belongs to a different breed of servants from the traditional, loyal 'criado' or family retainer. The traditional, patriarchal relationship is illustrated briefly by the following dialogue:

- Perdí, Ángel, tome...

- No, niño, no quiero nada.

- Pues entonces, adiós... (p. 261)

In contrast, the coachman is a salaried man, a professional servant, who works for money and has no further ties with the master he serves. 'The other members of the Glow retinue are similarly materialistic, and when the household is about to disintegrate, they take advantage of the situation in order to steal what they can. Significantly, their leader is

una sirvienta francesa, Lili, rubia como el oro y corrompida hasta la médula, (que) aconsejaba a sus compañeros de servicio que estuviesen prontos para alzarse con lo que pudieran en el momento del desbande. (p. 268)

It is interesting to observe that in this instance, as in many others that will be noted, it is the immigrant who sets the corrupting example. Other minor immigrant characters who swell the background scene are an English jockey of disreputable riding tactics (p. 252), and the inevitable Parisian 'cocotte'. In addition there is an unnamed Catalan who is considered abjectly ungrateful because he refuses to lend Glow, his original benefactor, a large sum of money in view of the fact that everyone in town knows that to do so would be to commit financial suicide. Once again, the prevailing attitude seems to be that it should be an honour to be allowed to sacrifice oneself for the traditional élite. Glow's anger is reinforced by the narrator's petty comments directed at the Catalan's clothes: 'un saquito de seda cruda amarilla a raíz de las carnes, y un pantalón de brin, decían bien claro que aquel hombre era un veterano del trabajo' (p. 204). This sort of observation is symptomatic of the nineteenth century Realist Novel's concern with 'homo socialis', where not only the home of a character, but even his dress, are considered appropriate attributes to define him. With regards to dress one norm is observed almost without exception. Gone is the myth of the prince disguised as a pauper; now the wellborn dress as befits them, with taste and effortless elegance; the poor are in suitable rags, and the social climbers can be detected with unfailing certainty by some 
telling flaw in their dress or in their wearing of it. A further illustration of this in La Bolsa will be found in connection with the Jew Mackser.

Martel does not limit his condemnation of foreigners to the lower orders. Fouchez is a French 'Marquis' who has fallen upon hard times and who comes to Buenos Aires where he starts off as a cambalachero, just like one of the turcos mugrientos alluded to earlier on, but through his initiative and inventiveness, he acquires a small fortune which he then invests in the soaring land market. He speculates his vast earnings on the Stock Exchange, where he meets Glow and becomes a respected member of the latter's coterie. His portrayal is not unfavourable, but Martel does not baulk making the following general comment: 'Pavoneándose muy orondo sobre los elásticos de su victoria, el francés representa al inmigrante aventurero, que tanto ha contribuído a crear los males que hoy nos agobian ...' (p. 153). The list of immigrant characters is continued by the mention of Francucheli and his cousin Carcaneli, who had come from Italy on an immigrants' boat, the former having become now 'el rey de la Bolsa, el fénix de la especulación, el genio sin segundo' (p. 33). Their career in Argentina constituted the typical example of a process that the author vociferously decried in all other instances, but in this one, it is looked upon with singular favour. Thus, Martel talks of him as 'engañado por las promesas de los agentes oficiales y trapisondistas'; he recalls his 'pintoresco traje de pana rayada' (p. 34), and inserts no mark of derision in the following statement:

... juntos se pusieron a trabajar en calidad de peones de una empresa ferrocarrilera, consiguiendo, en tres años de cruentas privaciones, reunir entre los dos un corto capital que Carcaneli centuplicó rápidamente, gracias a su talento audaz y a su prodigiosa actividad, llegando a dominar la Bolsa con sus golpes atrevidos de especulador improvisado, y conquistándose una posición social muy en relación con sus méritos. (p. 34).

This exceptional benevolence is easily explained: as David Viñas has pointed out in another context, ${ }^{10} \mathrm{La}$ Bolsa is built upon a structure of contrasts and the Italian banker has to prove a worthy counterfoil for his opposite, the Jewish banker Mackser, whose introduction had immediately preceded his. The portrayal of Baron Mackser could stand in the annals of vicious, anti-Jewish caricature. It is made up of stock-type physical exaggerations of a racist nature, which are combined with emotive moral judgements. Many of the features observed can be traced back to comments made in La France Juive, a highly inflammatory anti-semitic work written by E. Drumont and which Martel mentions specifically in $L a$ Bolsa: ${ }^{11}$ 
El que hablaba masticando las palabras francesas con dientes alemanes, y no de los más puros, por cierto, era un hombre pálido, rubio, linfático, de mediana estatura, y en cuya cara antipática y afeminada se observaba esa expresión de hipócrita humildad que la costumbre de un largo servilismo ha hecho como el sello típico de la raza judía. Tenía los ojos pequeños, estriados de filamentos rojos, que denuncian a los descendientes de la tribu de Zabulón, y la nariz encorvada propia de la tribu de Ephraim. Vestía con el lujo charro del judío, el cual nunca puede llegar a adquirir la noble distinción que caracteriza al hombre de la raza Aria, su antagonista. Llamábase Filiberto Mackser y tenía el título de Barón que había comprado en Alemania creyendo que así daba importancia a su oscuro apellido. (p. 31)

It is important to analyze Mackser's description in all its details, in order to understand its full implication. 'El que hablaba masticando las palabras francesas con dientes alemanes': this well balanced sentence, which is not devoid of humour, focuses attention upon the speaker's mouth, transforming his act of speaking to one of chewing, as if to blur the difference that distinguishes humans from other animals. Attention is drawn here and elsewhere to Mackser's difficulty in speaking French. Drumont writes on this point:

Cette impuisssance à s'assimiler dans sa substance même la langue d'un pays s'etend jusqu'à la prononciation. Le Juif, qui parle si facilement tous les idiomes, garde toujours je ne sais quel accent guttural qui le decèle à un observateur attentif. ${ }^{12}$

Another feature worth noting is the mixed nationality of the Jew, for it is an important accusation within a nationalist ideology. Again, Drumont writes on this:

La patrie, dans le sens que nous attachons à ce mot, n'a aucun sens pour le semite. Le Juif, - pour employer une expression énergique de L'Alliance Israélite, - est d'un inexorable universalisme. ${ }^{13}$

The effect of the opening phrase is reinforced by the next statement: ' $y$ no de los más puros, por cierto', which alludes to the racist concept of purity of blood, always a useful rousing point to be invoked in the interests of Nationalism. '... era un hombre pálido, rubio, linfático, de mediana estatura': the word 'linfático', with its scientific overtones, implying a listless, sickly disposition, acts upon the other three attributes so that jointly they give the impression of an unwholesome being. The fact that he is blond but of medium height marks an unfavourable contrast in the reader's mind, with the blond tall Aryan race. This suggested contrast is made explicit towards the end of the passage. '... y en cuya cara antipática y afeminada': again, one 
attribute works upon another, and just as any suggestion of romantic pallor had been dissipated by the accompanying scientific term, so with 'afeminada', which is governed in the reader's mind, by the preceding value judgement of 'antipática'. '... se observaba esa expresión de bipócrita bumildad que la costumbre de un largo servilismo ba becho como el sello típico de la raza judia': this phrase conjures up the stereotype of the grovelling Jew; the use of 'costumbre' in this context implies a certain acquiescence on the part of the Jews for their condition of servitude. By shifting the blame onto the Jews for their condition of servitude, Martel's attitude is in keeping with that which he adopted towards the mendicant cripples, when he blamed them for their deformities.

'Tenía los ojos pequeños, estriados de filamentos rojos, que denuncian a los descendientes de la tribu de Zabulón, y la nariz encorvada propia de la tribu de Ephraim': there is no specific link between the tribes mentioned and the physical characteristics attributed to them: Zebulun and Ephraim are names introduced in order to stress the foreignness of the character; his red, streaked eyes reinforce the message of 'unwholesomeness' and the Jewish hooked nose is a stereotyped feature. The use of 'denuncian' reaffirms the implication that it is an offence, even a crime, to belong to the tribes mentioned. Yet it is interesting to note that Drumont uses exactly the same attributes in his comparisons:

Henry Aron, avec ses yeux striés des filaments rouges, se reclamait de la tribu de Zeboulon, et Gambetta, avec son nez d'une courbe si prononcée, se rattachait à la tribu d'Ephraim. ${ }^{14}$

'Vestía con el lujo charro del judio, el cual nunca puede llegar a adquirir la noble distinción que caracteriza al hombre de la raza Aria, su antagonista': it is a traditional reaction of the élite to accuse the social climber of having a loud taste, and of looking out of place in luxurious clothes. ${ }^{15}$ Here, as in $L a$ France Juive, the polarization between élite and non-élite is not simply a matter of social class, but of race. The unbridgeable gap is that between Aryan and Jew.

There has been a certain amount of speculation as to the identity of Baron Mackser. B. Lewin, in Cómo fue la inmigración judía a la Argentina, offers an interesting suggestion:

Esto me hace admitir la versión que me trasmitió un distinguido amigo mío, perteneciente al antiguo patriciado criollo: que el repulsivo barón Mackser de La Bolsa, la primera novela antisemita argentina, intentaba ofrecer un retrato, o una caricatura, de Simón Ostwald. (p. 84) 
Ostwald was a German Jew, a publisher and a landowner who was active in cultural affairs and in matters of Jewish interest. ${ }^{17}$ According to Lewin's report, Ostwald was a respected mem ber of certain intellectual circles, but, generally, he was unpopular man. Whereas the possibility exists that Martel may have found inspiration in a living figure, the portrayal of Mackser is so much a conglomeration of prejudice that in effect it evokes a stock caricature and not an individual.

Mackser is accompanied by another Jew, to whom it is suggested that he is tied by the most sinister links. This second Jew fulfils a whole gamut of suspect occupations, being a 'white slave' trader, a journalist at the service of Jewish interests, and a jewellery dealer (pp. 31-2). The trio of Jewish characters is completed by the description of Jacob Leony, whose portrayal runs on the same stereotyped lines as that of his other co-religionists (p. 211). Yet for all the care, the hatred, the suggestive implications which lead the reader to a certain amount of expectation of vile behaviour, the activities of these characters is minimal, and in no way worse, or indeed, as reprehensible, as that of others. Their crime lies in the narrator's 'telling', not in his 'showing', a fact observed in the earlier novels, where immigrant characters are denigrated ex professo and whose condemnation does not appear to necessitate further elaboration.

Quite the opposite happens with the criollo characters, particularly Dr Glow and his friends. In cool, objective terms, judged by the dishonesty of their actions, they are all despicable criminals: impostors, defrauders, pimps, and horse ringers. A list of their activities gives the flavour of their misdemeanours: it includes the formation of a totally fictitious land company: the sale, on the part of a friend to another, of a non-existent recipe for the making of French liqueur, and the fraudulent extraction of money in order to set up the said liqueur factory: the spreading of false rumours in order to influence the value of shares, and finally, collusion with the 'starter' at the race tracks. Of course, Martel decries these practices. Indeed, his work is one prolonged accusation against the atmosphere which conduces to such behaviour, but he fails to lay the blame where it clearly belongs, which by the logic of the plot, should be with Glow and his associates. Instead, in describing these, Martel adopts a benevolent tone. The most innocuous of the band is Lillo:

Todo era simpático en Ernesto Lillo: la soltura de sus modales, que se resentían de cierta indolencia de muy buen tono; la energía, el vigor, la fuerza de sus veintitrés años, floreciendo dentro de un temperamento robusto y nervioso, y particularmente un no sé qué de valor y de nobleza que se desprendía de toda su persona, haciéndola muy atrayente y dándole ese a modo de poder 
sugestional que es el secreto del éxito de muchos en la ingrata lucha por la vida. (p. 17)

In view of the comments made about Mackser, the reader will note the particular approval given to Lillo's youthful vigour. Lillo's presence has a purely dramatic importance, so as to provide a seemingly noble excuse for Glow, who must save him from ruin, to sink deeper and deeper into an abysm of dishonesty.

Another character whose portrayal does not fit his behaviour is Juan Gray. Gray defrauds his sick widowed mother and his gullible brother of their inheritance, which he either spends on his Italian mistress or gambles away. He is the owner of the racehorse on whom Glow will eventually pin all his hopes. Yet Martel does not blame him directly, offering the usual explanation: 'se dejó arrastrar por el ejemplo de la juventud dorada' (p. 41). The most abject character of the novel, possibly the most abject character in the whole literature under review, judging by his actions, is Ernesto Granulillo. He is the one who masterminds the majority of the schemes, defrauding his brother with the same ease as he defrauds Glow, his ex-partner and friend. His ruthless treatment of his mistress includes all the clichés of the genre, such as the punishing withholding of his favours until she promises to extract a required sum of money. This she does from a Government minister who philosophically exclaims: 'Bah, de todos modos es el pueblo el que paga' (p. 109). Martel admits that Granulillo is 'lo más vil que ha salido a la superficie terráquea' (p. 109). Yet his presentation of the character is measured and not at all unfavourable, and the first impression, which is the one to act longest upon the reader, is that of a charming and adventurous young man:

Fresco y acicalado como una rosa, muy elegante y presumido, nadie hubiera podido imaginar todo el arrojo, toda la energía, todo el talento que se escondía detrás de aquel exterior delicado, femenil casi, detrás de la amable sonrisa de sus finos labios purpúreos, sobre los cuales el bigote castaño apenas se atrevía a insinuar una sombra ligera. Director de un Banco oficial y periodista ingenioso, conversador ameno y temperamento artístico refinado, gozaba de generales simpatías, especialmente entre las damas, cuya sociedad buscaba él siempre. (p. 43)

The author's biased inconsistency reveals itself most strongly in his portrayal of the main character of the novel, the much esteemed Dr Glow. So marked is the divergence between the information told directly by the narrator and that which is imparted by his actions, that it is hardly possible to reconcile the two. ${ }^{18}$ Glow is presented as a noble hero, the victim of evil 
times. His exalted position is suggested first by the British origin of his name, and then by its meaning. It will be recalled that in the previous work examined, the élite were always attributed a certain 'shining' quality. ${ }^{19}$ Except for a passing reference to his 'hermosa cara de hombre del Norte', there is no direct physical description of him, but his bearing, his early career, his lawyer's office, and his magnificent house, point to a man of elegance and sensitivity endowed with a brilliant mind. His haughty demeanour through the crowds that throng the Stock Exchange seems fully justified by his social position. The pride and satisfaction with which he reviews his newly acquired mansion draw no censure, for it is seen not as the ostentatious whim of a nouveau-riche but as the fitting abode for him and his family. According to the often repeated remarks censuring the age for its materialism and for its loss of simplicity in favour of an acquisitive spirit, there should be a feeling of underlying disapproval for the luxury of Glow's home. Yet the contrary is the case, and the impression gained is one of indulgence and admiration for the exquisiteness of every detail described, as witnessed in the following extract:

Era de ver la cara que el doctor ponía al contemplar aquellos muebles riquísimos, con sus tejidos que representaban escenas de guerreros antiguos, aquella alfombra de Obusson, de una sola pieza; aquellas paredes forradas, como un estuche, en seda color rosa pálido; aquellos cortinados espesos que colgaban majestuosamente de las altas galerías; aquel techo en que el pincel de un verdadero artista había trazado unos amorcillos a quienes la Du Barry hubiera visto complacida abrir las alas en su mejor retrete; aquellos bronces sostenidos en pedestales forrados en riquísimas telas; aquellos grandes espejos, con sus dorados marcos de filigrana y sus jardineras al pie, llenas de flores, como ofreciendo un premio a las hermosas que quisieran mirarse en su cristal biselado; aquellas mil chucherías esparcidas en desorden por todas partes; vitrinas de rara forma, que contenían objetos de fantasía; atriles caprichosos, con libros abiertos como misales unos, otros sosteniendo cuadritos de mérito; taburetes de raso pintado a mano, y allá en el fondo, una gran vidriera detrás de la cual se transparentaba otra sala envuelta en una penumbra que le daba no sé qué de fantástico y vaporoso. (pp. 73-4)

The lesson to be learnt is that luxury is only wrong when it is in the wrong hands. The narrator is at great pains to point out Glow's inherent honesty and respectability, saying that he is always the one to declare himself against any dishonest scheme, and to extol the virtue of honest business ethics. Thus, the reader is assured that:

El doctor estaba dotado de los sentimientos más puros, y era refractario a todo lo que saliera del terreno legal, abierto a las ideas honradas y generosas; pero el medio ambiente en que respiraba había influído lastimosamente en él. (pp. 55-6) 
This is the pervading attitude towards the character on the part of the narrator, and so strong is the imprint upon the reader that the assumption has often been left unquestioned. Thus, M. Lichtblau insistently refers to Dr Glow as 'the good attorney' or 'the very ethical and conscientious attorney'. ${ }^{20}$ A dispassionate look at Glow's behaviour, however, presents another picture. The reader learns that he has given up a successful practice in exchange for the easy gains of speculative finance, a step presented as inevitable because of the corrupting influence of the time. This excuse remains unproven. In fact this sentiment is an underlying premise of $L a$ Bolsa, but it is not substantiated by its own argument, the plot. Thus, the alacrity with which Glow agrees to join his friends in forming a fraudulent share company, which is based upon a sham city, a scheme which he himself calls a theft, cannot be convincingly attributed to the influence of outside pressure. The narrator's explanation for this, as quoted above, is not illustrated by sufficiently strong evidence. The acceptance to invest in a scheme to manufacture fake Chartreuse liqueur, points not to a brilliant legal brain, but rather to a greedy simpleton, a fact not lost upon the lawyer's percipient wife. ${ }^{21}$

Finally, the plan to participate in el tongo and to risk his creditors' money on a rigged horse race, is Glow's own idea, and the author's words 'iPobre doctor! iCuánto se conocía que le costaba hablar!' (p. 228). is hardly a sufficient excuse for the character's involvement in such an infamous act. Glow fails to live up to expectation, not only by his actions, but also for the opinions he holds and the attitude towards others that he sometimes adopts. His anti-semitism is virulent, and his arguments are contradictory and ill-formed. They too, as Granulillo, his opponent, remarks, can be found in Drumont's book. For instance, he accuses the Jews of trying to seep into criollo society, and he berates them for maintaining their separateness. His quotations from Jewish sources are crassly distorted, but any factual inaccuracy is irrelevant to his feelings which, as he himself admits, are the result of strong prejudice: '(los judíos) "Me sublevan, me inspiran asco, horror"' (p. 112).

Glow is at his most ludicrous in his breathless search for money, when he arrogantly expects people to lend him vast sums of money merely as a service to his good name, and in spite of the knowledge of his impending bankruptcy. Martel's idea of making Glow a tragic hero, victim of the debased surrounding climate, remains unfulfilled. Instead, Glow emerges as a vain, small-minded man, blinded by prejudice and arrogance. The lack of internal coherence in Glow's characterization is a serious flaw of the work, weakening not only its aesthetic effectiveness but causing a serious 
inroad into the ideological argument that it expounds.

Martel does not limit himself for the expression of his views to the fiction that he has built with and around the characters in $L a$ Bolsa. He feels free to include many direct rhetorical observations which are left to stand out, obtrusively, from the narrative, with the result that the most forceful way in which the author's feelings and ideas are conveyed, is not through the delicate workings of fiction, but rather in the more crude manner of the pamphlet. The overt message of the work is all too clear. As stated, the principal theme is that the country has lost the pristine quality of a more spiritual age by succumbing to the contaminating effect of the hordes of immigrants arriving without halt, and imposing their materialistic ethos and unscrupulous opportunistic behaviour upon a helpless native population.

The assumption of an idyllic past golden age is a time-honoured literary theme, but since it is offered here as an historical reality, it is perhaps relevant to recall for a moment the cruelty and viciousness that broke out among the provinces of Argentina on the very morrow of Independence, and which resulted in the terror of the Rosas regime, a situation which affected the whole of society. Nor can the fundamentally economic motivation which led to the bisection of the country be ignored; each faction fighting to preserve its own material interests. ${ }^{22}$ Viewed dispassionately, what Immigration did was to serve the interests of one group, to the detriment of the other, not impose a materialistic ethos upon a spiritual one. ${ }^{23}$ The ideology that led to Martel's falsified version of reality, persists in some areas of literary criticism. In the prologue to the 1946 edition, written to commemorate the fiftieth anniversary of the author's death, Adolfo Mitre repeats the views expressed in La Bolsa, using moreover the same moralizing tone and provocative imagery that is to be found in the original:

El desborde de las masas que llegan de ultramar guiadas por simples apetitos venales; la afluencia de capitales extranjeros con cuanto éstos entrañan de eficientes en su acción pero de peligrosos en su influencia, han ido promoviendo una atmósfera de utilitarismo absorbente, que se infiltra hasta en los sectores tradicionales de la sociedad. Caracteriza a la nueva generación ese escepticismo elegante en que suele florecer el goce de los bienes mundanos, y 'los hombres del 80' van esparciendo 'ironías' por los salones donde un boato de relumbrón ha substituído al decoro de la sencillez criolla, con la nobleza del jacarandá nativo sobre el cual ardía el sahumerio del abuelo español. ${ }^{24}$

This past, whose particular details are left unspecified, is clearly embodied by Doña Dolores, Margarita's aunt, a formidable female who steps in and 
out of the novel to provide a point of contrast with the surrounding corruption. She is a solitary remnant of a purer breed, rooted in the traditional Criollo values of stoicism, austerity, and valour. Presumably it is her age and virginity which has protected her from the corroding influence of the changed city, and she alone remains oblivious of its machinations and innocent of its taint. For this she is the most admired character in the novel, a yardstick against which to measure the degradation of the others. She is representative of the patrician way of life, lost under the pressure of new forces. Another figure who stands outside the maelstrom of the gold rush, is a young poet, sombre and impoverished. He, unlike Dona Dolores, is only too lucidly aware of the precariousness and artificiality of the city's seemingly spectacular economic edifices, whose impending debacle he foresees and forewarns. In his fleeting appearance, he most faithfully embodies the message of the work and indicates the emotional perspective from which it is preached:

Cree ver, allá lejos, muy lejos, al fin de la avenida por donde corren atropellándose los coches, una boca que se abre, se abre cada vez más, que luego se convierte en catarata, y de catarata en remolino, y que aquel remolino empieza a girar, a girar, con rapidez tan vertiginosa y con tan grande poder de atracción como al abismo que sirvió a Edgar Poe para escribir ese prodigio titulado El Maelstrom. (p. 158)

The spirituality of the past is almost a tacit premise of the novel; the materialism of the present, however, must be attacked vociferously. It is presented as part the programme of cosmopolitanism, an intrusion from Europe brought over by the flow of constantly arriving immigrants. Its influence is said to have spread to every corner of the city, but its shrine is situated in 'la Bolsa' itself.

This is described objectively as a financial organization and as a physical landmark of the city. But its role in the novel by far surpasses the realm of objective reality; the image gradually emerges of a Medusa-like figure, an irresistible temptress, an evil force set out to devour her victims. This allegorical presentation of 'la Bolsa' reaches its apotheosis in the description of the nightmare which torments the dying Glow:

Pero de pronto vió que los brazos que lo estrechaban transformábanse en asquerosas pata provistas de largas uñas en sus extremos. Y el seno palpitante se transformaba también, y echaba pelos, pelos gruesos, largos, cerdosos, que pirchaban como las púas de un erizo. Y cuando quiso huir, arrancarse a la fuerza que lo retenía, fué en vano. Las uñas se clavaron en su piel, y sus articulaciones crujieron haciéndose pedazos. En su espantosa agonía, alzó los ojos buscando la cara que momentos antes besara con pasión, y vió que las 
hermosas facciones que tanto había admirado, se metamorfoseaban lentamente. La boca se alargaba hasta las orejas, y agrandábanse y multiplicábanse los dientes, en tanto que los ojos, furiosos y bizcos, se revolvían en unas órbitas profundas y sin párpados. Y él entonces, debatiéndose en el horror de una agonía espantosa iloco, loco para siempre! oyó estas tres palabras que salían roncamente por la boca del monstruo: - Soy la Bolsa. (pp. 279-80)

The values by which 'la Bolsa' is judged, are the complete antithesis of the Positivist programme extolled by the writers of the earlier period, such as Sarmiento in Facundo and Alberdi in Peregrinación. The belief in economic progress as a desirable goal, providing greater well-being through closer integration with the leading nations of the world, is completely reversed. Martel decries the materialism of the age at every level. For example, he criticizes the new buildings of the city because they are constructed with a view for profit alone. He also disapproves of the principle of earned income as opposed to inherited wealth, which being part of the patrician way of life, freed the recipient from involvement in a competitive race, the invevitable (and for Martel degrading) result of the need for self-advancement. Thus, Martel is projecting the values of the old order, in order to fend off the advancement of the new. His attitude, however, is not always logical or consistent when describing the result of any innovation. He mixes a strongly expressed disapproval for change in general, yet qualifies his remarks when he comes to describe it in particular. His depiction of the long lines of carriages that can now be seen hurrying along the streets of Buenos Aires, provides a useful illustration of the point made. The carriages are decried for their novelty, their speed, their practicality, their luxury. Yet once the overall condemnation has been made, there are subtle gradations in the censure voiced regarding the individual coaches:

Aquello parecía una exposición al aire libre de cuanto vehículo han adoptado la holgazanería y la actividad humanas para trasladarse de un punto a otro. Cupés flamantes de gracioso porte, tirados por troncos de rusos o anglonormandos, que denunciaban la riqueza y buen gusto de sus felices dueños; ligeras americanas, de un caballo, sencillas, bonitas, como las usa la juventud elegante para pasear sus galas y su regocijo; tilburís desairados, guasos, plebeyos, propiedad sin duda de esos activos comisionistas que no se preocupan de la elegancia de su tren, sino de correr más aprisa que el tiempo; carricoches de alquiler, cuyo aspecto alicaído y trasnochado estaba en consonancia con las yuntas caricaturescas atadas a ellos; 'cabs' extravagantes, con su asiento atrás, alto como un trono y raro como la excentricidad inglesa a que deben su origen, y otras muchas variedades de ese género 'vehículo' que el industrialismo contemporáneo va enriqueciendo de día en día con nuevos e ingeniosos ejemplares, se interponían entre la vereda y el landolé del doctor Glow. (p. 10) 
The same mixed attitude is encountered in the other enumerative descriptions in the work, such as Glow's house, or the scene at the races. It brings forward the suggestion that the real enemy, in terms of values expressed in La Bolsa, is not so much the materialism itself but the ideology behind it, a Spencerian belief in the survival of the fittest, this being a struggle in which everyone can participate. Or, to put it another way, the most odious aspect of Capitalism as viewed in this work, lies in its demolition of the fixed protective barriers of a two-tiered feudal society. The author's weapon is to discredit the achievement by imposing on it canons of taste which, unlike carriages, furniture, or dress, cannot be acquired in an open market, but are reserved to an unchanging privileged few.

Fear of intrusion from the outside is at the root of the argument against cosmopolitanism. When Europe was a distant, unreachable goal, it could easily be looked upon as a paradigm of perfection, identification with which would serve to differentiate the patrician class from its mestizo servants. But once the implementation of the Liberal Programe has facilitated access both to Europe, and particularly from it, with massive immigration arriving yearly in Argentina, values are reversed, and protection is sought from the onslaught of immigration. This sees the beginning of an idealization of 'criollismo' for which undefined standards of purity are created and enhanced, ${ }^{25}$ whereas cosmopolitanism is turned into an outright threat. The immigrants are no longer considered the superior ethnic leaven of the days of Alberdi's dictum 'gobernar es poblar', but are repudiated as a contaminating element. The effect of Immigration upon the appearance and behaviour of porteño women is regretted in the following passage:

Allí podía observarse la variedad de tipos en que el cosmopolitismo avasallador ha descompuesto a la mujer argentina, quitándole aquel sello andaluz y picante que conservaba como preciosa herencia de la sangre española. Las rubias abundan tanto como las morenas, y de éstas eran pocas las que ostentaban aquel donaire que hechizó a Byron en una gaditana, y aquella esplendidez de formas que daba majestuoso realce a esa belleza que ya va siendo casi puramente legendaria. Era raro ver un par de ojos negros que no estuviesen artificialmente agrandados por el pincel, ni mejillas que no desapareciesen bajo una capa de polvos o albayalde. Y, después, un afrancesamiento en los trajes y modales, un falso exquisitismo parisiense, un estiramiento forzado que hacían ridículo contraste con los resabios de las maneras abierteas y chacotonas de los buenos tiempos de antaño. (p. 248)

The 'canker' of Immigration strikes not only at the ethnic level, but also at the political. In an impassioned speech, Glow blames the cosmopolitan 
composition of society for the general political apathy, saying that the immigrants' only concern is for their own well-being and that their opportunistic attitude has spread to the rest of the population:

-"Pero el oro es corruptor. Allí donde el dinero abunda, rara vez el patriotismo existe. Además de eso, el cosmopolitismo, que tan grandes proporciones va tomando entre nosotros, hasta el punto de que ya no sabemos lo que somos, si franceses o españoles, o italianos o ingleses, nos trae, junto con el engrandecimiento material, el indiferentismo político, porque al extranjero que viene a nuestra tierra, naturalícese o no, maldito lo que se le importa que estemos bien o mal gobernados. Haya dinero, prospere su industria, esté bien remunerado su trabajo, y él se ríe de los demás. Ahora bien, lo peor del caso es que se nos ha contagiado este culpable egoísmo importado; ia nosotros, los argentinos! Yo, para hablarte con franqueza, lo experimento en mí mismo. A pesar de todas estas declamaciones que ahora estoy haciendo bajo la impresión de un entusiasmo pasajero, sé que en el fondo no podría substraerme a los halagos de mi vida lujosa para lanzarme a ... a una revolución, por ejemplo". (p. 116)

This speech is of particular interest, not so much for the central argument that it pursues, which is consistent with that expressed throughout the work regarding the question of the ultimate responsibility of Immigration for the evils observed, but because the logic of the argument reveals the typical attitude held towards Immigration in all the contemporary works studied. This is one which views the immigrant only from the outside, as an object, thus completely failing to give any consideration to a problem from the immigrant viewpoint. In this case the author, or Glow, his mouthpiece, totally disregards (when accusing the apathetic immigrants) the question of whether they have even been given either the means or the motivation to take an active in the country's political life. ${ }^{26}$ Of particular interest, too, are the opening lines of the speech, for they echo precisely an observation made by Alberdi in Peregrinación, ${ }^{27}$ expressing the conflicting interests that exist between material welfare and patriotism. Yet whereas Alberdi advocated the pursuit of material advancement, precisely as a weapon to combat what he considered the retroactive effect of patriotism, the completely opposite view is taken here. It is clear that the threat to a national identity is beginning to make itself strongly felt. The root of the problem, however, to be discussed elsewhere, was that the national identity that was being defended was itself unestablished and ambiguous. The anti-cosmopolitan feeling in La Bolsa is channelled principally in one direction. While everything foreign, with the exception of British capital, is disapproved of, there is one group of people, the Jews, upon whom the most insidious and hateful invective is heaped. There are two possible 
explanations for this, both contradictory, yet not mutually exclusive. The one sees its inspiration in Europe, the other in Argentina itself.

The first, held by most critics who have shown an interest in this fundamental aspect of $\mathrm{La}$ Bolsa, ${ }^{28}$ stresses the fact that there were only a few Jews living in Buenos Aires at the time in question, and that it is highly unlikely that Martel had ever met a Jew in his life. ${ }^{29}$ His anti-semitism, therefore, is seen as another example of a cultural transplant which has been imported from Europe without consideration as to its relevance to the local reality. Thus, since one of the consequences of the confluence of nationalism and racialism in Europe was a widespread feeling of antisemitism, Martel adopts this hatred too. The nationalist argument accuses the Jews of forming a nation within a nation, without allegiance to the country in which they reside. ${ }^{30}$ This does not preclude the counterargument, that the Jews try to infiltrate the society in which they find themselves, and indeed both accusations are found in Drumont's work and in Martel's. The idea of the racial inferiority of the Jews was influenced, though not explicitly stated, by the writings of Count Gobineau, for whom Jews were a non-Aryan, Oriental element whose very nature was of a different modality. ${ }^{31}$

It is possible, therefore, that when Martel attacks the Jews, he is not directing his hatred at an existing group of people, but at the idea or concept that this people represents in his own ideological framework. Detrimental references are made about the Jews throughout the work: 'los que me inspiran recelo son los judíos, que empiezan a invadirnos sordamante' (p. $21)$; 'asociarse con los judíos, es ir contra la patria, contra la raza, contra todo lo que hay de bueno y honrado en el mundo' (p. 118); 'vampiros de la sociedad moderna, su oficio es chuparle la sangre' (p. 124); 'Leony, al casarse con la heredera en cuestión, no hizo sino seguir la costumbre judía, que consiste en acaparar la riqueza por todos los medios, siendo el matrimonio uno de los principales y más explotados' (p. 211).

The bulk of the argument about the Jews is concentrated in a protracted debate between Glow and Granulillo. It is a curious fact, noted by S. Bagú, that the only two balanced statements on this issue are pronounced by Granulillo, one of the most repugnant characters of the novel. ${ }^{32}$ The latter points to the blind prejudice which lies at the root of all anti-semitism, and says:

No reconozco esa diferencia que se pretende establecer entre unos pueblos y otros. Creo en la igual dotación ingénita de todos los hombres, y sólo a la naturaleza que los rodea y al grado de civilización que hayan alcanzado, atribuyo las diferencias que se observan entre ellos. (p. 129) 
But in the dispute, it is Glow who retains the upper hand. He has the most to say, he is the main character, and it is obvious that he is the mouthpiece of the author. He has no particular insight into the question of the debate, and holds no original ideas on the subject. All the arguments used by Glow (like Baron Mackser's description), are stock anti-semitic accusations which can be found, almost verbatim, in La France Juive. They concern allegations of Jewish separatism, of Jewish control of the press, of the threat of a Jewish invasion and of Jewish control of capital. A few examples will establish the connection. Drumont's thoughts on Jewish separatism have already been noted. ${ }^{33}$ Glow says:

Ellos, ellos son los que se resisten a formar parte de una raza que ha proclamado a la faz del Universo que todos los hombres son iguales; ellos, los que se resisten a firmar la paz con una sociedad que les abriría los brazos si no hubiera probado ya varias veces las dificultades de una reconciliacón imposible.(p.119)

Drumont writes: 'disposant par l'argent de toute la presse'; ${ }^{34}$ and Glow says: 'haciéndose dueños de la prensa' (p. 120). Drumont talks of 'envahir toutes les situations importantes', ${ }^{35}$ and Glow says 'conquistando todas las posiciones' (p. 120). Drumont gives the following example of the Jewish danger:

Le droit du Juif à opprimer les autres fait partie de sa religion, il est pour lui un article de foi, il est annoncé à chaque ligne dans la Bible et dans le Talmud. ... Contre le chrétien, le gentil, le goy ... tous les moyens sont bons. ${ }^{36}$

Glow repeats it as follows:

Hay en el 'Talmud', en ese código civil y religioso de los judíos, una cláusula curiosa, que no recuerdo al pie de la letra, pero cuyo sentido es éste: 'Si eres juez y se presentan ante ti dos litigantes, uno cristiano y otro judío, darás aunque no la tenga, la razón a este último, y serán un mérito ante Jehová todas las artimañas a que recurras para hacer aparecer como culpable al cristiano.' (pp. 121-2)

Even the one point on which the Jews find favour with Drumont is repeated by Glow. Drumont talks of 'cette admirable solidarité, qui est la vertu dominante de la race juive qui explique, qui justifie, qui legitime presque son succès, ${ }^{37}$ and Glow says: 'una sola cosa, en el orden moral, los hace simpáticos a mis ojos: el espíritu de solidaridad que los hace fuertes y poderosos' (p. 122). The object of these comparisons is to show the extent to which Martel's anti-semitism, possibly inspired by one source alone, is a crude and shallow copy of European ideas. 
La Bolsa is a work highly charged with metaphor and symbolism. In it, things are made to surpass the level of objective reality, and acquire moral and even supernatural dimensions. It will be recalled that 'la Bolsa' itself, the financial institution, was presented not simply as such, but as a female temptress, a clutching Medusa-like figure and the personification and seat, or temple, of Evil. Similarly, the Jews are not detracted simply as a racially inferior or nationally disloyal people, but as a sinister, irrationally powerful, malevolent force. As remarked by G. Onega:

El judío es atacado furiosamente como la encarnación del mal; es decir, no se ataca en él a los capitalistas, especuladores o banqueros, sino a un ente catalizador de lo demoníaco, a un ser metafísico que subyace encubierto y cuyo veneno se infiltra sigilosamente, sin que las víctimas lo adviertan. ${ }^{38}$

This is amply borne out by the tone of the following of Glow's assertions:

¡Ah! ¿tú no sabes la invasión sorda, lenta; la conquista callada, subterránea, pavorosa, de la sociedad moderna, que Israel viene llevando a cabo por el medio más vil y rastrero de que puede echar mano el hombre? ¿No sabes que los banqueros judíos son hoy los reyes de las finanzas europeas, y que ese Barón de Mackser, cuyo socio eres, es el general avanzado del ejército israelita lanzado sobre la América para conquistarla con el dinero, arma poderosa, formidable, contra la cual son impotentes todas las que podamos emplear nosotros, nosotros los arios, acostumbrados a luchar a cara descubierta, frente a frente, y demasiado nobles y confiados para no ser víctimas de los manejos traidores, escondidos, solapados de los descendientes de Judas? ... (p. 119)

And further on:

... tienen formada una gran asociación que se llama Alianza Universal Israelita, y cuyas ramificaciones se extienden a todas las partes del mundo en que haya modo de lucrar a costillas del hombre ario. Cremieux, que la fundó en Francia, centro de operaciones del pueblo maldito, en el año 1860, le dió una organización tan maravillosa, que hoy es quizás la sociedad secreta más poderosa del mundo. (p. 122)

The first explanation of Martel's anti-semitism is that in attacking the Jews, he attacks primarily an abstract entity, the embodiment of Immigration elevated to its maximum potential. This is the general opinion, expressed by L. Rusich, ${ }^{39}$ who quotes D. Viñas, who in turn quotes S. Bagú. It is based on Bagú's assertion that he has found no indication of deep racial prejudice either in the contemporary press or in parliamentary debates, or in historical, economic, political, or literary works. ${ }^{40}$ 
Not only is the present thesis one long argument of disagreement with such a view, but specific evidence exists contradicting Bagús assertions with respect to La Bolsa. For it is probable that Martel's anti-semitism did have some closer links with the national situation in Argentina than has hitherto been suspected. Argentina was one of the proposed countries for the establishment of an autonomous Jewish state. Under the auspices of the Baron Hirsch Foundation, there were plans to purchase vast areas of land on which to settle the persecuted Jews from Eastern Europe, particularly from Russia. There was a suggestion that at first five thousand Jews should come per annum, and that later this figure should be doubled. The issue was hotly debated in the contemporary Argentine press, where the project met with strong opposition. The debate on this issue is recorded by B. Lewin, who quotes editorial comments from the leading daily newspapers such as ElNacional, Sud América, La Prensa, and La Nación. ${ }^{41}$ The latter, which was the paper for which Martel was working as a journalist, printed a particularly prejudiced and unfavourable article. B. Lewin writes:

Pero la que arremete contra la empresa de Hirsch - por su posición general frente al problema inmigratorio y particularmente judío - es La Nación, al referirse al proyecto de venta, que califica de vergonzoso, desventajoso e irregular de 1300 leguas de tierra fiscal. Sostiene el diario:

'Ante todo, parece que el P. E. no se ha preocupado poco ni mucho de la calidad de la inmigración que en grandes proporciones se pretende introducir al país y que, sin embargo, antes de fomentarla y favorecerla, debería ser objeto de serio y profundísimo estudio. Las condiciones y aptitudes físicas y morales de los inmigrantes han sido objeto de vivas discusiones en los años anteriores; se ha demostrado cuán grande es la influencia que la nueva población ejerce sobre los naturales del país, hasta el punto de mejorar o empeorar las condiciones de la raza; y nos parece que debe importarnos a todos el desarrollo futuro del pueblo argentino.

'Diríase que ya se han olvidado aquellos teribles ataques, generalmente injustos, que hace cuatro o cinco años se dirigían a los inmigrantes del mediodía de Italia; diríase que se han olvidado las medidas que adoptó el mismo gobierno argentino, facilitando la inmigración del norte de Europa para contrabalancear la inmigración del mediodía.

'Y sin embargo, ¿pueden compararse los inmigrantes judíos a los inmigrantes del mediodía de Italia o de España? Todos los informes son desfavorables a la nueva población que ha de venir a incorporarse a nuestra vida; en todas partes donde los judíos se han reunido en número considerable han provocado cruzadas en su contra; se afirma sobre la base de hechos innegables, que en general son sucios, indolentes, inaptos, para las labores agrícolas; los Estados Unidos han resuelto resistir esa clase de inmigración. ${ }^{42}$

Eventually, due to dissatisfaction on the part of the Jews and of the Argentine Government, the plan was reduced to far less ambitious proportions, 
and the matter was amicably arranged, but two points of interest emerge with regards to La Bolsa. One is that the first contingent of Jews who arrived on the Weser in 1889 (the year before La Bolsa was written) met with strong opposition from the Immigration officer, and while his decision to refuse them entry was eventually overruled, the fact remains that antisemitism was a topical issue at the time when Martel wrote his novel. The other point is that the above-mentioned plan included a number of details which coincide, albeit at the most superficial level, with some of the allegations put forward by Martel in a highly perverted form. The Alliance Israélite Universelle did exist as an international organization established in Paris in order to help Jews all over the world. It was, moreover, backed by Baron Hirsch and by the banking family Rothschild, both of whom Martel names, and it did send emissaries to Argentina to open negotiations on its behalf, with a view to purchasing territory.

It is evident therefore that far from being an exclusively theoretical issue, there was some factual basis from which Martel's highly inflammatory and distorted allegations have probably arisen. ${ }^{43}$ This view, however, does not entirely contradict the earlier, more generally held opinion that Martel's anti-semitism was the result of a cultural transplant. Martel does not project the facts as they were affecting his country, i.e. whether a proposed agricultural Jewish immigration would be of benefit to it or not, but repeats the arguments and prejudices formed in countries with a history of Jews and anti-semitism. The suggestion is here put forward that the portrayal of the Jews follows a close parallel to that of $L a$ Bolsa itself, that is to say that a factual, objective problem, rooted in the socio-economic problems of the day, is transposed on to a moral plane, where it is endowed with symbolic properties and force.

To summarize, therefore, the Jews offered a convenient metaphor of the two main targets of Martel's attack, materialism and cosmopolitanism. The first by virtue of an image that survived since medieval times, in which the Jew was stereotyped in a role of moneylender and usurer, and the second, because they epitomized a people who held no allegiance to the country where they lived, which made them an obvious butt for nationalist feelings. Furthermore, the extreme foreignness of the Jewish people meant that they could be considered as the immigrant par excellence, and in the most totally negative light.

For in La Bolsa the portrayal of the Immigrant reaches its nadir. It is true that it was considerably unfavourable in the other works studied, but they did not really extend beyond a militancy against a physiologically inferior immigration. In La Bolsa, however, it is not merely this type of immi- 
gration which is rejected, but anything that is in any way connected with an Immigration policy. This includes not only the human element, but also all economic and cultural influences, which amounts to an indictment of the whole Liberal Programme in favour of an inward-looking spiritual proposal, promising the retrievement of an idealized Golden Past.

Martels's aim is not to preach reform from within the existing system, but to change its entire basis. By turning Immigration into a scapegoat for all its evils, as the active culprit and contaminating spirit of all that is at fault in the country, he has launched the most violent and far-reaching attack upon it to be found in the Argentine novel. Henceforth there would be no return to the liberal, cosmopolitan ideals. Works would still be written in favour of Immigration, but never again from the perspective which ignored the nationalist inspirations put forward in La Bolsa, with its implication of the essential purity and worthiness of the criollo people. 

PARTTHREE THE IMMIGRATION PERIOD: THE PRO-IMMIGRANT NOVELS 

The works to be examined in the following chapters differ from those in the preceding three chapters in that they display a positive attitude towards Immigration. They are: Bianchetto: La patria del trabajo, Teodoro Foronda, and Libro Extraño, and were published between 1894 and 1902, a period which included the peak years of nineteenth century immigration. This was a time when the country had completely recovered from its earlier political and financial difficulties, and the large increases in the number of new immigrants coincided with an era of spectacular economic growth. Whilst being largely in favour of Immigration, the attitude adopted in the works in question differs radically from that encountered in those written in the pre-Immigration period where, it will be recalled, the ethnic superiority of the European over the criollo, was presented as an axiomatic truth. This change is not surprising. The arrival of an immigration of such gigantic proportions as took place in Argentina in the last two decades of the nineteenth century, was bound to alter pre-conceived ideas about it, and to instigate a more cautious reaction among a population which must have felt itself decidedly threatened.

Two different reactions evolved: the first, noted in the works studied in the previous chapters, attempted to reject the phenomenon in its entirety, by declaring the immigrant to be permanently proscribed on the basis of biological laws of heredity. The second, which will be studied in the following chapters, seeks to find a way through which the immigrant may become acceptable, but on new and demanding terms. A noticeable shift has taken place from the entrenched Europocentrism of Alberdi's day towards a new, slightly artificial criollismo which was trying to establish itself in an attempt to counteract the impact that the living European onslaught was having upon the country's shaken identity. Thus, no longer was it hoped, as in the days of Sarmiento, that the criollo population might be submerged, or replaced by the immigrants, but, on the contrary, it was the latter who were looked upon very much as an inferior species. And yet, the country's prosperity depended upon the immigrant work force. The problem was delicately solved by a changed ideology, in which the strictures of Biological Determinism gave way to the more pliable demands of Environmental Determinism. This allowed for the immigrant to be 
credited with the potential to evolve under the influence of a beneficial environment such as, it was held, he would find naturally in Argentina. Thus, by releasing the immigrant from the shackles of inheritance, and offering him the opportunity of becoming a valued criollo, the writers of this period have salvaged the image of a valuable work force without betraying the efforts of a rising nationalism.

A literary movement known as criollismo, which aimed at the exaltation of an autochthonous culture, particularly as envisaged in rural areas, became alight throughout Latin America with the publication of Ariel, by the Uruguayan essayist Enrique Rodó. ${ }^{1}$ It reached its culmination in Argentine literature with Ricardo Güiraldes's mythification of the gaucho in Don Segundo Sombra. ${ }^{2}$ In this work there are only a few passing references to immigrants. These are always contemptuous in their tone, for Immigration has no welcome place in the idealized criollo society projected by Güiraldes. Its presence, therefore, is duly suppressed, illustrating the author's refusal to come to terms with a reality which ran contrary to the idealized picture of pure criollismo that he was trying to project. There exists, however, in Bianchetto: La patria del trabajo, a work which foreshadows in many ways the later masterpiece but in which the projection of criollismo is not posed antithetically to Immigration, but rather as its ultimate goal.

While not being such direct precursors of Criollismo as Bianchetto, the other two works to be examined in this section also begin to show an appreciation of rural and criollo values, in contrast with the earlier novels which were set exclusively in the city of Buenos Aires. 
Bianchetto: La patria del trabajo, ${ }^{1}$ was written by Dr Adolfo Saldías and published in Buenos Aires in 1896. Its author, better known as a politician and as a distinguished historian, ${ }^{2}$ set himself the task of writing a novel in order to popularize his ideas on Immigration. He had written on this subject in non-fictional form in a short treatise published in French in Paris in the year 1889, with the title La condition des étrangers residents. ${ }^{3}$ This pamphlet deals essentially with the question of national status concerning immigrants in Argentina. As the law stood at the time, they were still very much under the influence and protection of the government of their country of origin. Saldías was an ardent advocate for the greater integration of immigrants into Argentine social and political life, and to this end he sought to curb the power of the European governments to interfere in matters and disputes taking place on Argentine soil. Furthermore, he wished to instil among the immigrants a stronger sense of allegiance to their new country. Among other measures, he proposed that foreign countries should not have the right to set up primary schools in Argentina, arguing that it was during the early day of education that the strongest ties of national loyalty were formed. The main preoccupation of Saldías, however, and that which also constitutes the principal issue of his novel, is the question of the naturalization of immigrants. The Argentine government showed little inclination to integrate fully the immigrants into its civic and political system. On the contrary, by giving non-naturalized persons most of the privileges granted to Argentine citizens, while exempting them from the most unpleasant duties, such as military service, the government seemed pleased to perpetuate an economically expedient situation which made no demands of commitment on either side. It is precisely against this policy that Saldías wrote his now forgotten novel.

Crude and cliché-ridden, Bianchetto is an avowed thesis novel, aimed at presenting an exemplary portrayal of an immigrant. It was written by Saldías only because the more able belle lettrist, Miguel Cané, who was to have fictionalized Saldías's ideas, was unable to do so when obliged to take up a diplomatic post in Vienna. ${ }^{4}$ What the work has lost in literary merit, due to an approach which is simplistic to the point of naiveté, it has compensated by the transparency with which it conveys its own ideology. 
Bianchetto unfurls in the manner of a Bildungsroman, in which the hero undergoes an educational process during his formative years and from which he emerges purified in terms of the internal values of the work. These values are related to the optimism of Positivist ideology, the belief in the dynamics of an open society, and in the desirability of individual advancement. But above all, they are concerned with the ultimate perfection of Argentine society, in which such material advancement is accompanied by a spiritual evolution in which lofty feelings of patriotism are awakened:

El Bianchetto de hoy regenerado, educado en sus sentimientos, con una posición bien cimentada, querido y respetado, rico y con mucho camino delante, y el Bianchetto de ayer, desvalido, con el egoísmo de la miseria, sin vínculo con el mundo, destinado a vegetar en la obscuridad o la abyección que alcanza el bajo pueblo en las colectividades antiguas, donde las elevadas clases sociales campean con sus preocupaciones y sus exigencias, - era una prueba palpable de la excelsa bondad de esa idea humanitaria cuya dilatación es la que ha radicado en nuestro país las prosperidades que nos asombran.

No es extraño, pues, que Bianchetto, inspirado en los sentimientos generosos a los cuales debía su regeneración, fuese un agente de esa idea encarnada en el medio ambiente en que se había desenvuelto. (PP. 314-15)

The plot serves to illustrate the author's thesis. Repeating a pattern established with Inocentes o culpables and En la sangre, this too is a simple tale of a poor boy who went to America and 'made good'. What differs is the way in which this 'making good' is portrayed. The story is divided into three successive stages, set respectively in Genoa, Buenos Aires, and Azul. Thus, it begins in Genoa, when Bianchetto has just been left orphaned through the sudden death of his father. He is forced to earn his own keep and even help out an old aunt who has given him shelter but who herself lives in a hovel, in wretched poverty. The lad is befriended by two Spanish gentlemen on the way to America, from whom he learns how to sing and to play the guitar. From them he hears about the existence of a 'land of golden opportunities', and some months later, spurred by the death of his aunt, he decides to try his luck and follow them there. He manages to obtain a job as a deckhand in exchange for his fare, and after a tempestuous crossing, he arrives in Argentina. There he is immediately befriended by an older compatriot who lives in La Boca, the predominantly Italian quarter situated around the city's port.

Helped by everyone around him, Bianchetto finds work immediately, selling newspapers in the busy streets of Buenos Aires. In time, however, he becomes dissatisfied by the limiting nature of this occupation and, by 
some lucky chance, he meets Don Correas, a landowner from Azul who is won over by his vivacious manner and the sweetness of his guitar playing. Correas offers to take him with him to his estancia, and to make a true gaucho out of him. Bianchetto accepts with alacrity, and a warm relationship begins between the criollo landowner and his young immigrant apprentice. Bianchetto is instructed in the numerous activities which are carried out in a well-run estancia. His education, however, is not limited to an acquisition of technical skills, but comprises a deep understanding of criollo values and ethics. The next five years see the consolidation of this knowledge in Bianchetto, and his gradual transformation into a genuine criollo, so that he becomes physically brave, and acquires nobility of feeling while remaining respectful to the point of submission towards his benefactor.

The story disgresses into a discussion of the politcs of the day, in which the main issue is the battle between the Conservadores, who wanted the unification of all the provinces under the leadership of Buenos Aires, with a shared interest in the port's enormous revenues, and the Autonomistas or Alsinistas, as they were then known in Buenos Aires, who fought for the province to be able to maintain its autonomy. This meant that the rich Province of Buenos Aires would be able to benefit alone from her favoured geographical position as the country's gateway, and retain the soaring revenues which were being amassed by the port's authorities. ${ }^{5}$ The chapters dealing with contemporary politics are tenuously linked onto the narritive through the figure of Correas, who is a committed supporter of the Alsinistas. The latter awakens in Bianchetto personal loyalities as well as a civic consciousness, and the young man insists on accompanying him everywhere, even on to the battlefield. The point is underlined that there was no pressure upon Bianchetto to join in the fighting, since he was exempt by law from having to do so, but that he volunteered to participate actively in the affairs of his new country. Significantly, he both becomes naturalized and joins the Guardia Nacional.

The end of the story is devoted to Bianchetto's final integration and acceptance into criollo society. A passion develops between him and Correa's only daughter, which is nobly repressed on both sides. On his, because he feels intensely the unworthiness of his position, and on hers, because she has too much filial love to cross her father's wish that she should remain in his household. This shared submissiveness is interesting in that it places the immigrant on a par with women as inferiors in a distinctly criollo-male dominated society. Yet fortunately for Bianchetto, in Saldías's world an immigrant need not stay so forever, and when the ardent lover and patriot 
gives final proof of his nobility by placing his life at risk in the cause of love and country, he completes a long and severe process of initiation, and is generously accepted by Correas as a true criollo, and as his daughter's fiancé. The couple marry and have eight boys who become the foundation stone of a new generation of Argentines. Gradually, Bianchetto replaces his father-in-law as head of the familiy and of the estancia, but this is not seen as a usurpation on the part of the immigrant, but as the natural, desired course of events. For by the end, Bianchetto has left well behind any trace of his Italian origins, and takes his place as the new head of the estancia as a fully assimilated Argentine, a respected member of the criollo community. Bianchetto is a shining example for all who have arrived, and continue to arrive to that welcoming land, 'la patria del trabajo'. The story ends on an elegiac note, praising Argentina as the country which will receive all the destitute and bring happiness, through work and its 'espíritu ennoblecedor'.

Work is one of the principal themes in this novel. The seeming nonsequitur of the title, Bianchetto: La patria del trabajo, is explained by the story itself, which tries to encapsulate the twin preoccupations engendered by the Immigration Policy, i.e. the ethnic and the economic. Saldias's interest in the first is to evolve an acceptable attitude towards the immigrants which would not be detrimental to the native born, and his interest in the second is to project a work ethos in terms which would be acceptable to a society which prided itself on its own disinterested, nonmaterialistic values. The way in which the author circumvents this last contradiction, is by adopting a method well rooted in the Protestant ethos of work, which is to project work as a worthy, spiritually uplifting occupation in itself. The use of the emotive word patria in conjunction with trabajo, helps to create an aura of sublimity, and throughout one finds the underlying assumption of work as a positive, purifying force. This, however, is seen differently in the Old World and in the New. The story opens with the death of Bianchetto's father:

Bianchetto había quedado solo cuando apenas contaba trece años. Su padre, el único apoyo que tenía, acababa de sucumbir con las armas del trabajo en la mano. Calafate en la playa de los suburbios de Génova, cayó con tan mala suerte sobre un montón de herramientas y de maderos, que quedó allí exánime. (p. 1)

There is almost a heroic quality in this description, suggesting that his death, while working on a ship on the beaches of Genoa, was equivalent to death in active combat. Yet the overall impression given is that in Italy 
work is an exacting toil, related mainly to survival in an atmosphere of restriction and doomed poverty, whereas in America, work becomes a liberating force, and the means towards individual fulfilment as well as social harmony. Thus, when Bianchetto arrives in La Boca, he finds that his compatriots live in harmonious bliss and total identification with the native population. So potent is the satisfaction that they derive from their work, that this is said to protect them, and their children, from the effects of the deadly germs that multiply in the stagnant waters of the area:

El suburbio de la Boca del Riachuelo era ya en ese tiempo muy extendido y muy poblado. Era un hacinamiento de casas de madera construidas sobre pilastras de algo más que un metro, para defenderse de las crecientes del río y de los aluviones: - calles largas y angostas, que si no se inundaban a los primeros amagos de una creciente, o de una fuerte lluvia, era porque a lo largo de las inciertas calzadas se extendían zanjones donde siempre había agua verdosa suficiente como para que se multiplicasen, al amparo del sol y de la madre naturaleza, los bacillus del cólera, de la difteria y del tifus: - una población densa, trabajadora y vigorosa, que se mofaba de todos esos inconvenientes y de todos esos peligros, entre las notas alegres y bulliciosas de la tarea diaria que a todos alcanzaba. (pp. 91-2)

Work expressed through the naive simplicity of this picture of contentment, moves on to a higher, more spiritual plane, when Bianchetto goes to the pampas, there to become a true gaucho: 'una vida nueva, la del trabajo ennoblecedor, se abría para él, por los auspicios de un argentino del común que con la sencillez de los corazones generosos cumplía una obra humanitaria' (p. 116). Finally, it is 'el trabajo, la solidaridad que trae aparejada' (p. 296), which is seen as the main instrument of Bianchetto's successful integration.

All this reflects the basic premise of the work in which the materialism of Europe is contrasted with the spirituality of America. This continent is described in an over-idealized language, with imagery borrowed from the realm of the fairy tale. The impression given is that of a paradisiac quality in which the land of promise and golden opportunities refers not merely to an economic situation but to something ethereal. A utopian flavour permeates the work from the first mention of America in the opening chapter, to its concluding paragraphs. Thus, Bianchetto's innocent question, 'Y, ¿qué es América?', is answered as follows:

América es una espléndida promesa que se brinda a los hombres de todas las latitudes, desde lo alto de sus montañas, donde sólo los cóndores trepan; desde el extremo de sus ríos que parecen mares como el que tienes ahí enfrente, y hasta en las ondas de sus vientos que, como el Pampero, atraviesan 
del uno al otro hemisferio. América es el engendro del genio español y de la hada de las selvas; el genio y el hada se confundieron entre besos y besos que el misterio iba alargando, y esta unión fecundó una vida nueva, y fue como la cimiente imponderable que hizo converger a ella las corrientes de todos los puntos del globo. (p. 7)

There is, of course, a specific purpose behind this eulogy of America, and that is to encourage the continuation of immigration to Argentina. Yet this is done with a shift in the position from which the idea was first propagated by Sarmiento and Alberdi, for no longer is it a plea for Europeans to come and improve Americans, meaning criollos, but rather the reverse. The message here is more on the lines that Europe is a decaying continent, now unable to hold its inhabitants who, however, may look to America for hope of salvation. Saldías criticizes the Europeanizing ideas of the early statesmen:

Por costumbre, más que conscientemente; por imaginar la grandeza únicamente allí donde el trabajo de los siglos y los tesoros de la generaciones han acumulado las manifestaciones artísticas y los refinamientos voluptuosos de la civilización, repetimos eso de la semibarbarie de las campañas y conceptuamos a su habitante nativo como miembro de una raza deprimida; llegando en nuestras exigencias sociológicas hasta sostener que nuestro progreso habrá llegado a su auge cuando ese habitante, el gaucho, haya desaparecido. (p. 132)

Still using Darwinian concepts and terminology, Saldías alters the traditional position of the gaucho in the racial pyramid, by presenting him in an enhanced light, as the one stable element of Argentine population. There is a defiant note in his tone, indicating an awareness that what he is saying is still controversial:

Convengamos, pues, en que no se trata de una raza deprimida que constituye una rémora para la civilización; sino de una raza fuerte, que subsiste a través de las evoluciones sociológicas que se han sucedido en el espacio de trescientos años, y que concurre a esa civilización con la suma mayor de trabajo y de riqueza, que, hoy por hoy, pertenecen al país argentino.

Digámoslo de una vez, sin temor de incurrir a los ojos del lector en una declamación vana: el gaucho es el único factor permanente de la riqueza de nuestro país desde los remotos tiempos de la colonia. (p. 135)

The distinction mentioned in regard to the relationship of Europe and America is in accordance with the overall pattern observed in this novel. This is based upon a distinct hierarchy in which Europe lies at the bottom, and the unsophisticated surroundings of Azul, at the top. In conformity with the optimism of its message, the story evolves in an upward direction 
and Bianchetto develops spiritually with each journey that he undertakes. It will be recalled that the first part is set in Italy, in the port town of Genoa, which was the major port of embarkation for emigrants, and known as the escape valve of Europe. Life here is depicted as petty and materialistic due to the constraints of want and hunger. Bianchetto, like a picaro in seventeenth century impoverished Spain, is forever on the trail of an extra penny, which he must artfully hide from the vigilant eye of his grasping aunt. There is no venom in the portrayal of life in Genoa, and no abusive adjectives are used or moral strictures given, but there is a strong implication that in an environment of privation, people are forced to behave in a debased manner. This is best illustrated by the character of Bianchetto's aunt, tía Marcotta, who lives in a hovel, sleeping on the floor, having hardly anything to eat but the occasional plateful of polenta. She shares this willingly with Bianchetto, but a lifetime of poverty has made her instinctively want to grab hold of any material asset, so that she seizes upon anything that is given to Bianchetto, and makes increasing demands upon him to bring in more money. The scene of her seventieth birthday celebration shows the animal-like quality of their existence, which seems confined to a physical level, motivated only by instincts and appetites:

Y la ensalada era su plato favorito. La atacó con valentía suprema. Su cuchara buscaba con ansia infantil los pepinos y los hongos. Con el segundo vaso de vino ya no se acordaba de Bianchetto. Devoraba como una loca absorbida en la idea de que se convertiría en una ensalada a la que nadie podría acercarse sin morir. Cuando concluyó con las últimas rebanadas de pepinos y las últimas cucharadas de aceite, estaba cárdena. (pp. 54-5)

The excesses of the unaccustomed feast cause the death of the old woman, which is described solely from the physical aspect, with pseudo-scientific comments about the changes of colour that were taking place on her body and face. This is to underline the animal aspect of human life in Europe (p. 56). Not only the poor, however, are limited in Europe to a non-spiritual existence, for the guests at the luxurious hotel where Bianchetto earns a few coppers, seem also confined to a shallow lifestyle. The contrast between the two continents is particularly emphasized in the portrayal of women. In Europe they appear sensuous and unseemingly independent; in America they are physically untainted and submissive to their menfolk. The author's approval of this can best be judged from the following quotation:

Como todas las de su clase, Carmen había vivido perpetuamente asida a la pretina de su madre, sin otras nociones del mundo exterior que las muy ele- 
mentales y tardías que llegaban a su hogar. Pura, ingenua, de una ingenuidad que prevalecía sobre los cambios que la naturaleza iba operando en ella, sentía, pensaba y quería alrededor de sus padres.

iEl más allá!... del más allá no veía ella más que el despuntar de la aurora o la puesta del sol, y esto le bastaba para dormir con sueño de niño y para que se deslizasen sus días blandos, apacibles y alegres. (p. 206)

Carmen, who embodies the best of female criollo virtues, is contrasted with Mlle. de Tecke, a sophisticated and emancipated young woman who comes into contact with Bianchetto both in Italy and in Argentina. She is a colourful and exotic creature for whom there is no place in the ordered society created by Saldías, and who must therefore die. But even she is made to experience a profound change: in Italy she is a passionate, hotblooded girl who tries to seduce the innocent Bianchetto. She is characterized by her voluptuousness and her lust, but when she miraculously appears in Azul, it is an intrepid horsewoman, daring and noble, who engages the admiration of the gauchos and who dies 'con una expresión de indefinible ternura' for Bianchetto, 'púdica como esas vírgenes animosas y guerreras' (p. 307).

Saldías uses the concept of América as synonymous with Argentina, and when speaking of Argentina, it is mainly the Province of Buenos Aires which is considered. This is explained, no doubt, by the author's personal involvement in the politics of this province, but it also reflects the ever increasing domination of Buenos Aires over the rest of the country in all fields, including the literary. With the exception of Facundo, all the works examined hitherto are set exclusively in the city of Buenos Aires, and Bianchetto stands out, in fact, because although it includes the city of Buenos Aires, its action takes place predominantly not in the city but in the province of the same name. In fact, having established the basic contrast of Europe and America, this polarization is taken one step further, and in America, the distinction is made between the tainted way of life of the big city and the still pure life led in the country. It is true that the Beatus ille theme, praising the quiet of nature over the bustle of the city, has an important place in Hispanic literature from the Renaissance onwards, so that its influence would have spread naturally to America, ${ }^{7}$ but its purpose in this work lies beyond the re-kindling of a tradional literary topos. As will be demonstrated, the reasons for the glorification of rural life are political, economic, but above all, cultural.

The Argentine novel, born under the influence of Positivist thought and in the shadow of the European literary genres of Realism and Naturalism, had always upheld a view that opposed the above concept. The reason for 
this is that the age in which the optimum was industrial expansion such as practised in Western Europe, the image of the city had gained in prestige and the idea of proximity to nature had lost its appeal of godliness. Instead, nature became a retrograde force, which as Sarmiento said in Facundo, likened men's behaviour to that of the animals surrounding them.

Bianchetto is the first work examined which reverses the assumption that away from the city men are barbarians. Thus, the idealized picture of life in Buenos Aires as opposed to Genoa, gradually makes way for a more censorious attitude when the city is contrasted with the less sophisticated environment of the pampas. In this context, Buenos Aires is seen as the seat of ambition and hypocrisy, in marked contrast with the simplicity and authenticity of rural life. After describing the opportunism which characterize social gatherings, Saldías writes:

Así viven muchas gentes, muchísimos hombres en Buenos Aires. Continuamente sacudidos por las ambiciones, por las exigencias de su vanidad, y sin poseer los títulos suficientes para que los demás les disciernan la sanción del mérito, se revuelven en la lucha del egoísmo, mirando con desdén y antipatía todo lo que no se amolda a sus empeños.

... Esta existencia mísera de la holgazanería, que es la renuncia a pura pérdida de uno mismo, y del boato que hace a cada instante el vacío, contrasta con la vida activa de los hombres de las campañas, donde ese aburrimiento es una especie de ave de paso que en ningún punto se detiene. (pp. 193 and 195)

What follows from this is an over-idealized description of the gauchos' way of life, underlining the highly skilled quality of their tasks and the usefulness of their work. This is significant because it is probably the first instance in the Argentine novel in which the land, the principal source of the country's economy, is given a prominent role. ${ }^{8}$ What is underlined throughout these rare costumbrista pages is the healthy and soul-invigorating quality of the work, but Saldías does not shrink from stating the economic advantages that an immigrant labour force working on the land would bring to the country:

Millones de hombres pueden todavía asociar su pensamiento y su acción a esta obra del progreso moderno que, como evolución orgánica, ha de llamar justamente la atención en lo futuro.

Tierras fértiles e inmensas esperan todavía la mano del hombre para que las transforme a la sombra de la libertad, que es la madre fecunda de la labor reproductiva. (p. 318)

From the demographic point of view, too, it was important to encourage the immigrants to settle on the land since increasing numbers were choos- 
ing to remain in the capital which was already showing signs of overcrowding. ${ }^{9}$ Furthermore, it need hardly be mentioned that the development of an agrarian economy was one of the principal interests of Saldias's political party. Yet another vital consideration which is apparent in this work is the need to project a strong cultural effigy which would be truly Argentine, in response to the growing crisis of identity from which the country as a whole was suffering. The increasing cosmopolitanism of the city, which Martel has decried so negatively, is also fought by Saldías, but where the one had proposed a return to an imaginary Golden Past, the other offers a utopian future, creating a national model of perfection to which everyone was able to aspire.

Saldías placed this image of the idealized criollo away from the Europeanized capital, in the remoter regions of the province. The artificial nature of this idealization of criollo values can be judged from the number of allusions relating to European culture which permeate the work. Some are extravagant and far-fetched:

Seis liras 75 céntimos, exclamó la tía Marcotta con un desprecio tan hiriente como el de la hija de Appio Claudio ya fastidiada de las ofrendas de Cátulo. (p. 17)

And again:

Lucía esplendorosa la belleza minervaica de esas mujeres de Homero que se batían con Aquiles, y que trasuntan las vírgenes heroicas de Virgilio y del Tasso en la envoltura encantadora de las Camilas y de las Clorindas. (pp. 22-3)

There are over fifty in all; moreover, none has been found which refers to an indigenous American culture. Yet a move has been made away from the former ideal criollo, and educated urbane gentleman, of fair complexion, well travelled in Europe and versed in its thoughts and customs. The model criollo projected by Saldías is Don Jesús María Correas, a wealthy landowner whose education consists in that he can do everything that his gauchos do on the land. He is generous, but proud and dignified:

Cuando entraba en la trattoria subía derechamente al cuarto que siempre ocupaba, se desabrochaba su tirador recamado con algunas onzas de oro y repletos los bolsillos de billetes, se sacaba de la cintura el puñal y hacía de cuenta que estaba en su casa, con la única diferencia de que jamás admitió complacencias en su cuenta de hospedaje.

Una vez que Fiori lo pretendió, respondióle sonriendo dulcemente, - 'Cuando deba pedir limosna, amigo Fiori, se la pediré a usted porque sé que tendré 
que agradecérsela'. Altivez de raza que no desmiente el perfil que de ella hacían los oficiales del rey de España, cuando a mediados del siglo pasado hacían notar como un peligro para la metrópoli ciertas peculiaridades grandiosas en el carácter del hijo de la Pampa. (pp. 104-5)

His home is simple and his ways unsophisticated:

La esposa y la hija de Correas divisaron a su dueño, desde la tranquera donde contemplaban la puesta del sol de aquella tarde. El gaucho atrajo a las dos sobre su pecho y siguió hasta la casa contándoles las novedades que había visto y dándoles las prendas que le habían pedido les trajese. Bianchetto siguió a su patrón, y a las preguntas de la esposa, Correas se lo recomendó diciéndole cómo lo traía y que lo hiciese dormir en un ranchito pegado a la modesta casa de material y que él no había querido deribar, porque fué el mismo que ocupó cuando recién fué a ese campo. (p. 122)

The immigrant, typified by Bianchetto, is not to be excluded from this idealized society. His acceptance follows a pattern of development which adheres to the structure of the novel observed hitherto. Thus the hierarchical progression established between Genoa, Buenos Aires, and Azul, is mirrored by the changes that occur in Bianchetto's personality as he moves from one place on to the next.

The three different settings correspond to different stages in the development of Bianchetto's spiritual education. At first, in Genoa, he is shown to be a likeable boy, living within the narrow confines dictated by stark necessity. His existence, as mentioned, is reminiscent of that of the traditional Spanish picaro who, too, had to plan and scheme for every morsel of food. The qualities able to develop under such conditions are clearly limited to a sharpness and quickness of mind and to a keen instinct for survival, that is to say, to the lowest rung of the scale of values implicit in the work itself. Bianchetto's preoccupation with money is intense:

Si habría perdido el medio marengo que le dió la joven extranjera! ... Esa cuasi lámina de oro ino se le habría resbalado en la precipitación con que la ligó con otras monedas en el extremo de la falda de su camisa?

Bianchetto se incorporó en la obscuridad, llevó las manos al atadijo, tanteó, pero ... iimposible! las piezas de cobre eran más grandes ... Empezó a desatar, cuidando de no hacer ruido. Desató ... desató ... deshizo los dobleces con la prolijidad con que un cirujano cambia un vendaje, y contó ... una palanca ... dos palancas ... un franco ... iMadona! ... un sudor frío le bañó mientras sus dedos convertidos en garfios querían arrancar aquella moneda del misterio que la cubría, con la fuerza de espíritu con que Colón arrancó del misterio a la América.

Por fin respiró ... la moneda estaba ahí ... (p. 20) 
The crossing to America, however, marks an important transitional period between the influence of the two cultures, and it is here that the metamorphic process that will operate upon Bianchetto begins to take effect. The first indication is given of the moral potential of Bianchetto: 'pero en Bianchetto había la pasta de un hombre fuerte. Una vez metido en el camino, adelante, se dijo' (p. 67). It will be recalled that a violent storm had broken out during the course of the voyage, causing much havoc among the terrified passengers. The pages recording the incident include lengthy descriptions of the appalling conditions under which immigrants travelled, the documentary value of which has been noted by L.Rusich. ${ }^{10}$ Yet there is another side to the scenes depicted which is more symbolic in character. During the worst hours of the storm, the immigrant passengers make an appraisal of their past lives, and become aware of their many shortcomings. This is presented as the birth of their moral consciousness, and they emerge from the crisis as more receptive towards the beneficial influence of America:

Las sombras más puras, los recuerdos más gratos, las impresiones más tiernas, fosforecían en esas imaginaciones calenturientas, como luciérnaga en tibia y obscura noche de verano. La infancia, las caricias de la siempre bendita madre; los primeros besos del amor, con la harmonía del ruido que produjeron, y el perfume de la mujer que los recibió; la risa de los hijos mostrando hasta las muelitas recién salidas; los proyectos de felicidad arrullados ante la lumbre del hogar, al lado de la esposa purísima y respetada; la serie de esfuerzos para honrar el nombre de los hijos que nos cerrarán piadosos los ojos; todo lo que pudo sonreir, halagar y estimular en los días de una vida sobre la cual ya no se contaba, se amontonaba, se chocaba, se estrellaba, se hacía pedazos en el cráneo de esa gente devorada por la fiebre, que era otra tempestad tan horrible como la del Océano. (pp. 72-3)

And a little further on:

Cuando apareció el día, y por la bóveda celeste como colosales moles de algodón se arrollaban las nubes blancas en veloz carrera hacia el Norte; y el sol brilló en el horizonte proyectando sus rayos sobre la maltrecha cubierta del Colombo ... ioh! toda esa gente mustia, hambrienta, a medio vestirse, cayó de hinojos y dió las gracias a Dios.

Sí; dió gracias a Dios de buena fé, y en su plegaria íntima quizá reprodujo los votos de reforma que hizo an el momento supremo del peligro y que, quizá también, después olvidaría. (p. 82)

The next stage takes place during Bianchetto's brief stay in Buenos Aires. Here he lives among a community of immigrants, having found immediate hospitality at the home of Ercole Fiori. A native immigrant 
from Italy, Fiori fulfils the positive portrayal of the immigrant, the man who has all the right attributes to settle satisfactorily in a new country and become a useful member of its society. He is a businessman, the owner of a thriving trattoria, and he typifies the immigrant who is content to make money in Argentina but who basically remains uncommitted. Fiori has reached only a halfway mark, having maintained his immigrant quality. There are higher goals to achieve and Bianchetto senses this. Thus, when the opportunity presents itself for him to move on to the pampas, he seizes upon it. It is on an estancia, in the heart of the Correas household, that Bianchetto first encounters the purest facet of criollismo and recognizes the end of his journey. He awakens to a world of spiritual values, kindness, and a sense of duty:

El hecho es que, cuando al cabo de algunos meses Bianchetto pudo hilvanar las impresiones que le producía su nuevo género de vida, encontró desde luego, que el trabajo era, más que pesado, rudo, por esa ronda en el campo, a caballo casí todo el día, y a veces de noche; por las lluvias y el sol que tenía que soportar alli donde no había más abrigo que el poncho y el sombrero de ala angosta y volcada sobre los ojos, y por cierta monotonía que imponía la esclavitud de hora y de momento, y a que estaban sometidos desde el patrón hasta él, que era el último.

Pero no se sentía dispuesto a rebelarse contra ello. Se daba cuenta de que le imponían ciertos deberes para que alcanzara ciertos beneficios; y movido por el egoísmo y por una impulsión de respeto que, sin saberlo él, le inspiraba el hombre bueno que allí le condujo y que compartía las faenas más rudas, hallaba cierto halago en poner de su parte todos los medios para que ase hombre le encontrase digno de las promesas que para sí se hacía. (pp. 124-5)

And again:

Y a medida que su corazón se educaba en esta escuela diaria de la simpatía, más arraigado se sentía en esa casa tan humilde, donde su espíritu iba descubriendo horizontes tan nuevos para él. Y al favor de tan nobles estímulos, la idea más o menos imperfecta de la responsabilidad propia, de la gratitud, del desinterés a que obliga el proceder siempre elevado, comenzaron a suavizar y después a dulcificar y a disipar el egoísmo en el corazón de ese niño que hasta un año antes miraba a los hombres con desconfianza o temor, y las cosas como instrumento de su ruina, pues había rodado a través de los unos y las otras sin saber lo que era una satisfacción.

En una palabra: al favor de la moral en acción que practicaba esa familia del común y del medio ambiente que la propiciaba, Bianchetto se educaba en su sentimiento; y tras una serie de revelaciones gratas para su corazón, íbase formando la conciencia clara de los deberes a los cuales se sentía atraído. Esto acusaba ya la transformación que en él se operaría. (pp. 130-1)

While learning how to become a gaucho, he undergoes the final lap of his 
purifying process. Once more, the documentary is accompanied by the symbolic, for Bianchetto's instruction in the intricate art of baquia (knowledge of the terrain and cattle-raising, described in some detail in pp. 196 to 199$)^{11}$ - results in a concomitant understanding and acceptance of a purer way of life. The philosophical aspect is not treated with the same degree of intensity as in Güiraldes's novel, with which this work has already been compared, and as a mentor Correas manifestly lacks Don Segundo's inner depth and emotional richness. But what is foreshadowed in the earlier work is a glorification of an ethos of bravery and stoicism as found away from the sophistication of the city.

There is yet another phenomenon that occurs during Bianchetto's metamorphosis into a true Argentine, and that is his assumption of a civic consciousness which leads him not only to wish to become a naturalized citizen of his country of adoption, but also kindles such patriotic fervour in him that on two occassions he chooses, freely, to engage in active military service. The didactic element present in this totally unrepresentative behaviour is easily detected, particularly in view of the ideas on assimilation expressed by Saldías in his treatise on this subject.

As mentioned earlier, there was, contrary to the policy adopted in the U.S.A., little pressure put upon immigrants to adopt Argentine nationality and become integrated into the political structure of the country. This situation denoted a certain lack of commitment both on the part of the immigrants and of the government. For the former, immigration had always retained a certain transient characteristic, since for the most part, they kept their loyalty to their homeland, hoping to return there once their fortune was made. For those in power, on the other hand, the immigrant was primarily a controllable object of expediency, to be used and discarded at will. At first there was little need felt by either party to embark upon a programme of integration but increases in the proportion of immigrant population showed that such a detached attitude could no longer be maintained. ${ }^{12}$

Exemption from military service was obviously a serious stumbling block to the harmonious relationship between the immigrants and the criollos, particularly in the rural areas where the majority of the government's troops were forcibly recruited. The singling out of the gauchos to fight in wars which they saw as contrary to their interests, bringing further immigration and further unwelcome changes, caused a resentment vibrantly recorded by J.Hernández in the pages of Martín Fierro. ${ }^{13}$ Yet what has been immortalized in Martin Fierro as a tale of cruelty and abuse, is euphemistically described in Bianchetto as follows: 
El desierto, el desierto inmenso hizo lo demás. Ese engendro fuerte, animoso v reducido a sí mismo se destacó ahí, soberano en su aislamiento, trasuntando en su romanticismo primitivo algo de la grandeza de la Pampa tanto tiempo ignorada de los hombres de las ciudades, quienes se apercibieron de lo que el gaucho valía recién cuando se vieron enriquecidos con sus estancias a las cuales iban una vez por año, entre otras causas por la falta de vías cómodas de comunicación; o cuando se vieron obligados a pedir al gaucho ayuda para fundar la patria y asegurar las conquistas del derecho.

El gaucho fue desde entonces soldado cruzado de la idea nueva, que no alcanzaba sino del punto de vista de la libertad para sí adorada. El sacrificio fué él cuestión de mero deber ... (pp. 136-7)

This sort of false colouring of history is an indication of Saldías's didactic fervour, and of the utopian quality of his work. Thus when he attempts to narrow the gap between the native rural inhabitants and the immigrant newcomers by presenting a hero who would adopt their way of life even to the point of participating willingly in their wars, Saldías is being prescriptive, not realistic, as can be seen from the tone and language of the following interchange:

-iUna bala! ¿y qué me importa me toque una bala? ¿No puede tocarle a V. que deja su mujer y su hija? ¿No tienen madres y hermanos esos muchachos que van con V.? Yo no tengo familia, no tengo más que a V.; cuando V. se marcha es porque va a cumplir su deber. ¿Y por qué no quiere que lo cumpla yo? ¿Porque he nacido en Italia? V. me ha dicho que en este país se confunden todos los hombres trabajadores. Pues yo quiero seguir ahora la suerte de todos esos con quienes yoy a vivir; y si V. no me lleva ... si V. no me lleva, agregó Bianchetto, haciendo un esfuerzo, me iré solo y trataré de no perderme en el campo para llegar adonde V. esté.

Correas no conocía a Bianchetto bajo esta faz. Lo contemplaba asombrado. Las últimas palabras del muchacho, tan sumiso siempre ante sus indicaciones, le hicieron comprender que era capaz de hacer lo que decía, y que de todo lo que pudiere suceder en tales circunstancias lo peor no era llevarle consigo.

- Bueno amigo, le dijo, venga conmigo, que al fin no le ha de pesar aprender también a pelear en esta tierra donde todos somos soldados cuando llega el caso. (pp. 142-3)

The most important moment in Bianchetto's story takes place on the battlefield when he suffers the severest injuries which almost cost him his life. This shedding of blood, or, as it were, this baptism by fire, sets the seal upon his final conversion, and he returns, triumphant, a true gaucho and a worthy suitor for Carmen's hand:

Bianchetto era naturalmente el objeto de las felicitaciones. La nueva campaña en que había asistido y en la que a pique estuvo de perder la vida, acentuó su fisonomía marcial y patriótica entre las gentes del departamento que lo 
consideraban tan criollo como el que más. Una comisión de vecinos, presidida por el comandante, le presentó una nota en la que recomendaba a la consideración pública el acto de arrojo del joven capitán que había levantado dignamente el nombre de la guardia nacional del Azul. Bianchetto recibió la nota conmovido y se la entregó a Carmen. (pp. 276-7)

Bianchetto has travelled the whole trajectory from the spiritual as well as material poverty of his childhood, to the full richness of his maturity. L.Rusich calls him 'quizás el primer gaucho italiano de la literatura argentina, ${ }^{14}$ yet this needs qualification. Bianchetto is not an immigrant character who adapts and assimilates into Argentine life, but an immigrant who undergoes a complete metamorphosis, starting on the high ocean, continuing during his apprenticeship on the estancia and which is completed in active combat, shedding with each lap of the process further trace of his immigrant past, until all vestige of it has been removed:

¿A quién le habría ocurrido conceptuar extranjero a Bianchetto? Ni a él mismo. Su sangre derramada juntamente con la de los valientes gauchos con quien se había criado; su sentimiento y su voluntad enérgicamente le habían llevado a confundirse con la población nacional. (p. 295)

This highly idealized portrayal of the perfect immigrant is of the utmost significance because it encapsulates the essence of the attitude adopted towards Immigration in Argentina, which is to accept it in principle but without taking into consideration a realistic appraisal of the cultural changes that such a massive movement must perforce bring in its wake. By making such inordinate demands upon his hero, Saldías has set an impossible standard: he has created the official version of the model immigrant, but failed to produce a credible figure with whom real immigrants might identify. His portrayal is symptomatic of the literature under review, in that it reflects an ideal which is completely out of touch with concrete reality. In the long run, this extreme example could only work against his most ardent wish, which was the closer integration of immigrants with criollo society.

Viewed by comparison with the total rejection found in the earlier works, Saldías's position is in favour of Immigration. Yet seen upon closer examination, it has become clear that this positive disposition towards the immigrant does not really involve acceptance of him as such. The immigrant is still considered an inferior being, but whereas the earlier works stressed the permanency of this condition through their belief in an unchanging heredity, Saldías's optimistic vision chose instead to project the adaptability of the immigrant to the propitious Argentine environ- 
ment, 'donde la naturaleza irradia a cada paso bienes fecundantes' (p. 123). The intial rejection of the immigrant, therefore, remains a constant feature of the literature under review, but there is a fundamental difference in the appraisal of his potential. The conditions of acceptance are clear enough: it is not Bianchetto the Italian immigrant who is welcomed, but the whitewashed figure who has chosen to eradicate his past and to submit himself to a complete process of acriollamiento. The most striking aspect of this work is its total refusal to come to terms with the reality of a hybrid society, attempting to force it out of existence by the projection of another, completely falsified vision of reality. 
The next work to be considered is Teodoro Foronda, named after its eponymous immigrant hero. Written by Francisco Grandmontagne, who was himself an immigrant, this is the only work studied in which the Immigrant's situation is looked upon from the inside, with sympathy and understanding for some of the problems arising from it. Moreover, it is the only novel in which an immigrant character is idealized for displaying, maintaining and defending those qualities which he has by virtue of his immigrant origins.

Grandmontagne, of Basque origins, was born in 1866 in Burgos and arrived in Argentina as a seventeen year old youth. He worked as a peón de pulperia (village store hand), and as a farm labourer in the Province of La Pampa, and later he lived in Buenos Aires in a conventillo. He had first hand experience of the events he portrayed in fiction. ${ }^{1}$ He was a self-taught man, and like Alberto Gerchunoff after him, he became a journalist of note. ${ }^{2} \mathrm{He}$ worked for one of the leading porteño papers, La Prensa, and edited another called La Vesconia. Grandmontagne died in San Sebastian, in Spain, in 1936.

The novel includes many autobiographical details, and offers much valuable information on certain aspects of small time provincial life, but what makes this work unique in the literature under review is the angle from which the story is told. So far, all the works studied have dealt with the subject of Immigration from the point of view of the receiving nation; Teodoro Foronda alone records a lived experience.

An interesting feature of Teodoro Foronda is that while it was conceived from the exact opposite angle to all previously studied works, there is one basic point of resemblance between them. In its general outline, it conforms to a pattern established by the 'Novel of Immigration', regarding the immigrant's undisputed rise from poverty to riches. The assumption of the automatic economic success of the immigrant is here maintained; in fact, there are no failures in this respect recorded in the literature under review.

Having established a point of similarity with the other novels, it now remains to underline the essential difference. This concerns the attitude of the narrator to the event described: it obviously lacks the antagonism of 
the early anti-immigrant novels, but it differs, too, from the pro-immigrant novel Bianchetto, a novel with which it has much plot material in common. Both have a strong didactic strand, but whereas the first was extreme in its preaching of the lesson of acriollamiento, Teodoro Foronda is the first work since the abstract pronouncements of Sarmiento and Alberdi which extols as virtues the materialistic qualities which are ascribed to the immigrants.

The novel's merit has been pointed out as early as 1901 by the Spanish author Juan Valera, who wrote in his Ecos Argentinos: 'Todo en Teodoro Foronda está bien observado y descrito y la novela se lee con interés sin que el libro se caiga de la mano'. ${ }^{3}$ Yet, possibly because of its excessive length and numerous digressions, to which Valera refers with regret, Teodoro Foronda has become an almost forgotten work, cursorily mentioned in Histories of Literature, but never analyzed in depth. Even Gladys Onega, in her study of Immigration in Argentine Literature, devotes only one short paragraph to this work. ${ }^{4}$

Teodoro Foronda was published in $1896 .{ }^{5}$ It is an extensive work running to 638 pages, divided into two volumes which in turn are divided into four parts. The work rests principally on a double axis: the vertical progression of Teodoro Foronda in the economic field, which conforms to the pattern followed hitherto and is presented as uninterrupted and inevitable, and the horizontal axis of social integration which proves to be infinitely more complex. Volume I deals mainly with Teodoro's arrival in the old port of Buenos Aires (the story is set in 1865) and with his early life as a young immigrant, making his way in a land of boundless possibilities. In Part One the action is set in Buenos Aires and relates Teodoro's early experience, which is not dissimilar from Bianchetto's: he too is befriended by a customs official, and he too is taken in by a rich paisano, the product of an earlier immigration, who behaves in a fair but ungenerous way towards him. The description of Teodoro's life as a shop assistant in his compatriot's affluent store, his many hours of work, sleeping on a bed hastily made up at night on top of the counter, his relationship with the other assistants as much as his wide-eyed observations on the richness and variety of the stock, coupled by explicit information about avoidance of customs dues, offer a rare and valuable insight into the contem porary commercial scene. Teodoro, like Bianchetto, also makes the journey by carreta, an ox-drawn cart, to a small provincial town where a job lies awaiting him, but there the similarity ends, for the Italian immigrant was to embark upon a process of acriollamiento, whereas Teodoro is never to lose the imprint of his immigrant status. The society in which Teodoro moves in 
the provincial town of Añahualpa is realistically portrayed in that it consists of both criollos and other immigrants. Moreover, unlike the protagonist of other novels, Teodoro continues to move all his life in a society in which both immigrant and criollo coexist. Teodoro's apprentisceship is not idealized like Bianchetto's, in gaucho skills, but is more plausibly set in the commercial scene, where he masters the art of selling. Like his author, Teodoro works in an all-purpose store where he carries out his duties not only conscientiously, but with imagination and verve. While for instance humouring his criollo customers and ostensibly accepting their drinks, he substitutes water for gin and manages both to stay sober and pocket the cost of the drink. It is significant that in this as in many other incidents the immigrant is shown to get the better of the criollo.

The problem of the relative merits in a hierarchical scale of values between immigrant and native is pursued in Part Two. Teodoro has risen in the firm's employment, having become a distributor. During his visits to a neighbouring estancia he has met María, a poor, dirty, ignorant gauch $a^{6}$ to whom he feels greatly attracted but whom he later discards. Here too it is interesting to draw the distinction between Teodoro and Bianchetto. The latter, pure, noble, aspired to gain the hand of the landowner's daughter but felt himself separated by a cultural abyss from her; Teodoro, more realistically perhaps, turns his attention to a poor local girl, but in this instance it is be who feels himself greatly superior to her. Two children are born of this sporadic and illicit union and eventually, after a certain amount of social pressure Teodoro agrees to marry the unfortunate María. But she, torn from her natural abode and piteously neglected by her disdainful husband, withers and dies like some wild vegetation which has been transplanted and left untended. In the meantime, Foronda's share in the firm in which he has been working has increased so that when left a widower he is able to return to Buenos Aires with his children and set up house there as a wealthy man. The economic success of his life seems well established, and it only remains, in Volume II, Part Three, for Foronda to consolidate his position, first as full partner in his old firm, where he had first served as an apprentice, then as a banker and eventually as President of several charitable organizations, an honorary title given only to the very rich. As already mentioned, this vertical success of Foronda takes place almost as a natural development requiring little explanation. In Part Four the drama evolves mainly around the conflict between Foronda and his two children who, having been educated at the most exclusive schools and moved in the most aristocratic circles of the land, would readily disown their father's immigrant origin. This whole section of the work is dedi- 
cated to dealing with Foronda's feelings, his suffering at his children's ingratitude and heartless behaviour. The confidante of all his troubles is Doña Purita, his criolla mistress. The few chapters set in her home add a characteristic view of the milieu of the demi-mondaine.

The point of view of Foronda's children, Simón and Teresa, is presented most unsympathetically; both are derided for their pretentiousness, the first as an arrogant, pompous young lawyer, and the second as a vapid, empty-headed young female. The son, Simón, takes his cynicism so far as to reduce his paternal surname, Foronda, to a mere initial, while prominently displaying his mother's in a shiny plaque which conveniently is made to read: Simón F. Bolívar. Furthermore, he discreetly lets it be known that he was named after an illustrious forefather. This is the final mark of rejection that causes Teodoro's despair and leads him to an attempted suicide. $^{7}$

In Teodoro Foronda the immigrants are a 'presence' which is maintained throughout the work. They are not, as in some other works, anomalies projected against a criollo background. Thus, both Buenos Aires and Añahualpa are constantly described as places where there are numerous immigrants. They appear not as tolerated but as fully accepted members of society. The business world seems peopled almost entirely by immigrants, who seem to have developed a profitable commercial network throughout the country. This is notably presented as a positive achievement in contrast to the sinister allegations made in La Bolsa about a similar situation.

The portrayal of Immigration in Teodoro Foronda can be looked at on two levels: on the one, it follows, as already mentioned, in the tradition established so far in this thesis of the hard-working and materially successful self-made man, but at another level it can be seen that each immigrant figure has been further developed with some individualizing trait adding variety to what had hitherto been presented as an undifferentiated homogeneous mass. Thus, whilst adhering to the basic outline of the stereotype, Grandmontagne presents a more multiform collection of immigrant characters.

One of these is Silvestre Ruano, who originates from the same impoverished Spanish village as Teodoro and who has become the owner of a big warehouse in Buenos Aires. He is a rich, pompous, selfopinionated man, steeped in the work ethic and a believer in the theory of the survival of the fittest. He says proundly to the newly-arrived Teodoro: 'Aquí se aprende a ser hombre y a vivir cada uno de sus propias fuerzas' (vol. I, p. 35). When he asks about his family back in Soria, Don Silvestre 
adopts a somewhat superior air, as if despising all who stayed behind. $\mathrm{He}$ seems to blame Teodoro for his poverty-stricken appearance in torn clothes, as if implying that he is responsible for his misfortune: 'Pero hombre! iCómo vienes así tan derrotado y tan cochino!' (vo. I, p. 34). Don Silvestre's world is harsh and calculating. It embodies the principles of competitive capitalism and of laissez-faire which in Kolakowski's words 'ensures victory to the strongest, stimulates human energy and initiative, eliminates the weak, and favours the survival of individuals beneficial to the species'. ${ }^{8}$

Everything said about Don Silvestre shows that he conforms to the image of the typical immigrant. Yet it is interesting to note that the author is at great pains to emphasize his individuality, arguing that his weaknesses are simply part of human nature. He is viewed not as an immigrant, but as a human being:

Dios nos libre de asegurar que don Silvestre fuese un hombre malo; pero tampoco hemos de mentir diciendo que era bueno, y a fuer de sinceros y afectos a la verdad, (mérito que no reparamos en ostentar a falta de otro de mayor valor), aseguramos que era un tipo vulgarísimo, formando en las filas de ese lote inmenso que constituye mayoría en la humanidad. Tenía muchas virtudes aparentes y no menos defectos ocultos, o mejor dicho semi-ocultos, porque bien se la transparentaban a través de un disimulo mal apañado, debido a las debilidades que sufría su voluntad y a cierta tendencia farolera y exhibicionista que constantemente ponían en evidencia lo solapado de sus intenciones. La hipocresía, para ser bien cultivada, requiere cierta cultura y su miajita de talento, dones que nunca quisieron radicarse en don Silvestre Ruano. (vol. I, p. 39)

Grandmontagne adds:

Pero no hay en la humanidad carácter completo, ni virtud inconmovible, ni nada, en fin, que deje de ofrecer su lado vulnerable. La Naturaleza, basada en un sapientísimo principio de organización, amasó su obra con materiales tan variados y múltiples, sólidos unos, insólidos otros, que nunca faltan resquebraduras o rendijas por donde se cuela el fétido airecillo de la infamia o el sutil y escurridizo gusanillo de la debilidad. (vo. I, pp. 44-5)

Don Miguel Guriezo, another successful Spanish businessman, is completely different from his compatriot. He is unambitious, preoccupied mainly by philosophical matters. An observer of life, his experiences have led him to formulate certain opinions on the basis of his own ideas and not by adhering to received opinion:

Como ya se habrá advertido, era Guriezo lo que vulgarmente se llama una persona decente, muy pacífico, dotado de sentimientos elevados, sin grandes 
ambiciones, culto, de inteligencia regularmente sólida y bastante formulista y aparatoso en lo relativo a la moral, base, según él, de la armonía del mundo. Su único defecto consistía en ser un galgo incansable en el campo de la filosofía esencialmente humana y en una pícara inclinación hacia los discursejos y peroratas, que a propósito de cualquier festival añahualpense, endilgaba a sus convecinos. Poseía un criterio amplio y no exento de lucidez, que es condición superior al conocimiento de cuantos textos se han escrito para desarrollar principios psicológicos que no tienen fin sino en la desaparición de la idea. (vol. I, p. 197)

When Teodoro seeks his advice on whether to marry the penniless girl he has seduced, Don Miguel's answer is based on the view that the gaucha, being an uncivilized creature gave herself in a state of innocence, but that he, Teodoro, who knew the duties and obligations of his actions, was guilty in moral and religious terms and had to repair his fault. His advice, one feels, is very different from any that he might have received from someone considered a more typical immigrant in his outlook. Don Guriezo betrays his commercial background only in the amusing metaphoric resumé of Teodoro's moral dilemma:

Me parece muy bien pensado. Cada cual debe cumplir sus compromisos. Los pagarés hay que retirarlos a tiempo, o de lo contrario no firmarlos. Tu caso es como quien tiene siempre pendiente de pago una letra vencida. Las cuentas corrientes pueden prolongarse con astucias y promesas; pero una vez producida la obligación, la cosa cambia de aspecto, y es necesario cumplirla si se quiere salvar el buen nombre de quien la contrajo ... Ya comprenderás que te hablo metafóricamente, en sentido figurado ... por si no entiendes de términos finos. (vol. I, p. 198)

Guriezo is the rare figure in the Argentine novel of the indiano, i.e. the Spaniard who came to America and returned home as a wealthy man. Yet the allegiance of the author seems to be to his new country, for Guriezo is said to have died in Europe just when he was about to return, disillusioned by the backwardness and bigotry of his home town (vol. II, p. 30).

Another Spanish immigrant offering a picturesque example of the common theme of rise from rags to riches is Don Pantaleón Atapuerca. The description of his early childhood tells of the conditions of extreme poverty and the lack of possibilities which afflicted many of the inhabitants of the more backward parts of Europe, causing them to emigrate:

En los albores de su juventud fue cabrero. Cuentan las crónicas forondinas que Atapuerca salió de la escuela de su pueblo precisamente cuando aprendió a deletrear con los dientes, o lo que es lo mismo, a comerse el silabario. Su 
padre, que era el boyero de la soriana localidad, antes que la modelación interna del cerebro de su hijo, anhelaba se le endureciesen las piernas y adquirieran la requerida consistencia para poder trepar por los peñascales y breñas ejerciendo de pastor, con lo cual debía concurrir el muchacho a secundar los esfuerzos del autor des sus días en el sostenimiento de una prole numerosa, nutrida a duras penas con patatas, sin mezcla de otras cosas de mayor substancia, y pan de centeno, porque el oficio no daba para más. (vol. II. pp. 5-6)

His life in Buenos Aires, at the mercy of his despotic uncle, Don Silvestre, seemed at times even harsher to the unhappy boy than that which he had to endure in Soria:

Pero, después de varios años de torturas, otro fue el pensar de Pantaleón Atapuerca, experimentando su carácter uno de esos cambiazos que hacen como nuevos a los hombres. Ascendido a vendedor, vislumbró, en no lejano horizonte, un porvenir halagüeño. Como el oficio de vender no requiere una instrucción esmerada, sino conocer a mucha gente del comercio, ser flexible, un poco zalamero, activo y bastante audaz, fácil le fue a Pantaleón imponerse del cargo, y hasta de lucirse en él, pues toda la clientela del registro le conocía, prefiriéndole en sus compras a los otros vendedores, sin duda por su cercano parentesco con el patrón, lo cual siempre supone cierta anticipada jerarquía comercial.

Y héte aquí al humilde Atapuerca, al rudo cabrero, saliéndose de la vaina, cual garbanzo madurado repentinamente por un golpe de sol canicular. ¿Qué manera de mandar a los subalternos! iQué ínfulas las suyas! (vol. II, p. 9)

Yet within a few lines in the narrative, Pantaleón too emerges a changed man: now it is he who is authoritarian, domineering, in short, a tyrant with his subordinates. He becomes indispensable to the firm, and in fact it is his very rusticity and total lack of susceptibility which ensures his success as the best salesman of Buenos Aires. Pantaleón undergoes none of the refining process of his other compatriots. He remains uncouth, ignorant, unimaginative, a dogged salesman and dedicated worker who feels ill at ease in any company other that that of the business word. As if his name, Atapuerca, were not sufficient indication of his primitiveness, the chapter in which the author concentrates on him is called Un jabali en sociedad. The following is an extract from it:

Era cosa de ver al Gobernador de Soria, encogido, rojo, sentado sobre el mismo borde de la silla, las muñecas afirmadas en el canto de la mesa, las manos al lado del plato, cogiendo aturdido el tenedor para comer la sopa, hablando lo menos posible, a fin de que no se le fuese algún escorioso terminacho o interjección de aquéllas que usaba en la zafiedad de su trato con amigos y comerciantes. (vol. II, pp. 208-9) 
Atapuerca is endowed with all the negative characteristics of the immigrant, reminiscent of the Dagiore of Inocentes o culpables and of Don Esteban of En la sangre. Yet in this work he is viewed with good humour and indulged as an oddity both by the narrator and by the other characters, who are kindly disposed towards him. The final impression is that there is something laudable in this character's unpretentious simplicity in the face of the affectations of Foronda's children and their friends. But this show of benevolence is unique in the literature studied.

Immigrants also fill the canvas of secondary figures in areas outside that of commerce. There is mention of one peon from Galicia (vol. II, p. 245) but on the whole they seem to come from the middle classes. All the teachers mentioned (with one exception) who come to the house to instruct Teresita are of European origin: the piano teacher is from Lombardy, the French teacher from Marseilles, the art teacher is a mixture of Andalusian and Florentine extraction, the embroidery teacher is Catalan. Grandmontagne has the following to say about them: 'la mayoría infelices que venían a ocultar en América su impotencia para luchar por la gloria en los verdaderos centros artísticos' (vol. II, p. 94).

These, presumably, were thought to be situated exclusively in Europe, thus illustrating a prevalent belief in the essential superiority of European cultural life. No doubt because of the nationality of the author, this is the one Immigrant Novel in which Italians do not constitute an important number of immigrants. Instead, the British are portrayed in an unusually frank and unfavourable light. Bearing in mind their untainted image in other works, particularly in La Bolsa, it is interesting to note that in Teodoro Foronda they are willing partners with the local élite in projects of bribery and contraband. Mr Puk, an early immigrant who arrived in 1860, became rich with the building of the railways, in close association with a local landowner, Don Anselmo Antequera. Antequera managed to bring pressure to bear upon the Argentine government to obtain a concession, and Puk travelled to London to put out a tender for the job. There he was offered a bribe which he accepted and shared scrupulously with his Argentine partner, thus dismantling the typical image of British probity and uncorruptibility. British pride also suffers a setback. When Mr Puk is spoken to by his employer as though he were a menial servant, with arrogance and anger, he is said to have reacted calmly because 'él no pierde el negocio aunque le llamen parro judío' (vol. II, p. 202).

There is yet another occasion when the British are said to be taking part in a contraband project: 
- En mi plan están confabulados varios directores de empresas de ferrocarriles y algunos miembros de la diplomacia extranjera.

- ¿Los ingleses? ¿Porque serán los ingleses los del ferrocarril?

- Sí.

- iSe prestan a esas cosas?

- iLa gran flauta! Son como garrapatas cuando pueden hincarse en el Fisco. (vol. II, p. 292)

There are several disparaging references to the British, particularly in connection with their investments in Argentina and their role in the building of the railways. Grandmontagne talks about

nuestros Ministros de hacienda, los cuales se preocupan muy poco de la historia, porque tienen que emplear toda la máquina de hilvanar ideas en salir de los atolladeros financieros que en la actualidad nos rodean, debido a la incomparable cordura de gobernantes y gobernados y a la prodigalidad y desinterés de los ingleses, que tanto nos amaron antaño, y a quienes mediante Dios, los maizales y trigales, las lanas, los cueros y los cuernos, les hemos de pagar algún día, para que allá en Londres no anden los milores y ladies charlando, con su bocaza de ballenato, lo que no deben, (sino lo que se les debe) y poniéndonos además de oro y azul, en un lenguaje que no cuadra a su estiramiento ni a su fama de acreedores perpetuos y pacientes. (vol. II, pp. 54-5)

On another occasion he makes the following remarks:

Imagínese el lector al hambriento enfrente de una chuleta: imagínese al comerciante que, en vísperas de declararse en quiebra, le toca la lotería; supóngase a Bismarck recibiendo de los franceses aquella espuerta de millones por indemnización de guerra; juzgue la alegría de un Ministro de Hacienda argentino que logra pagar a los ingleses, o a éstos cuando consiguen apropiarse de nuestros ferrocariles. (vol. II, p. 100)

The same sentiments are expressed with even stronger irony:

Gran error sufrió Monroe cuando dijo: 'América para los americanos'. Más acertado hubiera estado afirmando que la América del porvenir sería para los Lincolns con lana y cuernos y para toda clase de bichos ingleses. (vol. II, p. 115)

British capital, which in La Bolsa was referred to in terms of 'una confianza que nos honra" is felt here as a heavy liability. Given the vast sums involved and the prominent role of British interests in the Argentine economy, ${ }^{10}$ it is surprising to find that Teodoro Foronda is the only work studied in which this fact figures with any prominence. The stereotype of the unromantic, self-interested opportunist has usually been someone like Dagiore, a newly arrived Italian peasant, but in this work it is the British who are seen as such: 
- A vos que no te saquen de las estancias, de los ferrocarriles y de los bancos.

- Creo que es lo único digno de preocupar la atención de los hombres, repuso bestialmente el hijo del inglés.

- Dejálo, ché, hermano, - manifestó Langredo dirigiéndose a Simón. Para éste vale más el pasto que las ideas. Estos engendros de ingleses son tremendos; toda su filosofía es tangible, hierro puro, leguas de tierra y moneda acuñada; sus novias son las locomotoras; su arte la electricidad ... (vol. II, p. 214)

Against this background of immigrant charaters, one figure, that of the eponymous hero of the novel, stands out for the scope and complexity of its portrayal. This is not meant to imply that Teodoro Foronda is a great literary creation, but that given the context of superficiality and manipulative didacticism in the literature studied, Foronda is conspicuous as the one protagonist who is allowed to develop naturally, and whose genuine problems are treated at length and with compassion. When looked at from one angle, Teodoro is seen to follow very much the pattern established by the novel of the Immigrant in that he arrives as a young, penniless boy, finds work immediately, becomes rich, marries and has children. Yet where he differs from other protagonists is that by not being merely an exemplary creature, having to illustrate a particular thesis, but a rounded figure, with good and bad qualities, he shines for his inner vitality in a gallery of flat two-dimensional, rhetorically conceived creatures.

Teodoro's vertical progression has already been noted: his arrival as an ignorant, penniless boy, his diligence in his work, his sober behaviour, his astuteness in business and in dealing with the customers are all features which he shares with other immigrant characters. Although in this novel the process of Teodoro's rise is described in greater detail than in others, its outcome is never questioned, neither by the narrator, nor by the protagonist who from the earliest days feels the certainty that his dreams in this respect will become true:

'iReconcho, si yo llegara a ser el amo de esta casa!'

$\mathrm{Al}$ prorrumpir en esta silenciosa exclamación, le pareció escuchar entre los pliegues del rollo de lienzo que le servía de almohada, una voz que le decía: ‘iLlegarás, Teodorín, llegarás! Cuando vino don Silvestre, era much más gaznápiro que tú, y ahora tiene un fortunón. Es cuestión de paciencia. (vol. I, p. 60)

Teodoro's progress, however, takes place not only on the economic plane; in time he develops all the necessary social graces and becomes an educated and respected member of society - sufficiently so to enjoy prominence in 
the cosmopolitan setting of Añahualpa, and later even in Buenos Aires, on the Board of the venerable Banco Universal del Río de la Plata:

En el espacio de muy pocos años, Foronda se hizo popularísimo en la capital Argentina. Varias sociedades de carácter filantrópico, le hicieron su presidente, y de casi todas era miembro directivo. (vol. II, pp. 17-18)

After his success in Añhualpa, Teodoro's first years back in Buenos Aires are spent in consolidating the foundations of his fortune. He expands his interests in the field of commerce to that of international high finance, dealing with transactions in Manchester, London, and Paris:

He aquí un detalle que conviene consignar en honor de la vigorosa inventiva forondina. Teodoro fue el primer registrero de Buenos Aires que inventó la patraña esa de tener casa en París, llamado de este modo a la habitación que en algún cuarto piso de la capital francesa ocupaba el comisionista o comprador del registro bonaerense, cuyas relucientes chapas rezaban así:

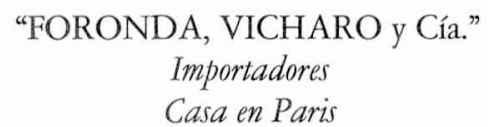

Rue de la Gironde No. 15

La ingeniosa innovación dio su campanillazo entre los comerciantes de las calles Rivadavia y Victoria especialmente, los cuales estaban de acuerdo en que Teodoro tenía mucho talento y era el importador más espabilado que se conocía en los anales del trapo. (vol. II, p. 17)

He is the first immigrant said to be innately intelligent. He has cultural ambitions and he widens his education, seeking the company of the learned. The outer man seems wholly too successful to be as deeply affected by a sense of inferiority with regards to his children, and Grandmontagne lacks the necessary skills to explain the split in Foronda's personality. Yet what is of importance here is less the observance of norms of verisimilitude, but the rare portrayal of the inner emotions of an immigrant character.

Teodoro is an ambitious person, a quality which in other works has been considered in a negative light, allied to a vulgar materialism alleged to be characteristic of the immigrants. In this novel, however, ambition is neither derided nor praised, but simply seen as one of the material ingredients of the new socio-economic system of the country, basic to the ideology of individual advancement and the survival of the fittest. The importance of Teodoro Foronda lies largely in its candid acceptance of reality on this score, devoid of hypocritically projected viewpoints. Teodoro's 
ambition for social as well as economic advancement leads him at first to behave selfishly, acting unjustly and even with cruelty towards María Bolivar. She, it will be recalled, was the dirt-ridden daughter of the gaucho Don Leandro. He uses her for his own satisfaction, and discards her with impunity, considering her as little more than an animate object whose thoughts and feelings are of no consequence. ${ }^{11}$

This incident, which to begin with seemed an unimportant event in a society in which such abuse was common practice, is made to assume greater importance as a precedent for the conflict between father and son which fills most of the action in Volume II. Thus, whereas it was almost taken for granted in most of Volume I that the succesful young immigrant should take, as part of his rewards, a young local girl, 'una gaucha india', without much thought for her, a more delicately sensitive climate was needed towards the end as a background for Teodoro's emotional preoccupations in Volume II. For it is easier to feel sympathy for a protagonist who has just been bereft of a much loved wife (and Teodoro repentantly saw María's true worth in the end), than for one who by a stroke of good fortune has just rid himself of the social handicap of a misalliance. Teodoro and María's union is the most inconsistently drawn episode in the whole work. Having derided the gauchos with much moral indignation for their filth and the general bestiality of their life, the author suddenly discards the virulent racism displayed earlier on, and, blaming Teodoro for his undue assumption of superiority, he converts María into a complex, highly sensitive woman, marked above al by the dignity of the suffering. Thus, neglected, unloved, insecure, conscious of her own inferiority, María has no will to fight the illness that is afflicting her. She dies a heroine and a saint, her grave adorned by a flower which seems to say: 'No remuevan esta sepultura, que es el refugio de una santa' (vol. I, p. 310).

There is a basic repetition of the same theme when first the European Teodoro fells ahamed of his gaucha wife and then, years later, his criollo son feels ashamed of his immigrant father. But Grandmontagne does not develop a suggestion of poetic justice; for him, the two events are clearly distinguishable and fundamentally his sympathies are with Teodoro.

The tragedy of Teodoro is centred around the difference between two generations, the first who was wholly preoccupied with achieving material success, having little time left for other problems, and the second who was weighed down by preoccupations of social acceptance, something which was felt to depend increasingly upon cultural rather than economic background. ${ }^{12}$ In those works in which Immigration is viewed from the outside, as a solid and homogeneous mass, the sons of the immigrants are 
presented as continuations of their parents, whose characteristics they inherit and perpetuate or even aggravate. Grandmontagne, looking at Immigration from within, places father and son in an antithetical relationship, thus capturing a conflict of identities which reflected a serious problem of the times.

Teodoro's immigrant status seemed never to be a hindrance, it was something he bore easily, almost imperceptibly. It allowed him, as shown, to rise not only economically but also socially among his own generation. But his children, who move in a society where money is no longer enough, feel strongly the disadvantage of their background. They, it could be said, are the victims of the ideology expounded in Bianchetto, where in order to be accepted, the immigrant was forced to renege on his past. Saldías presented this idea in the most positive light but is easy to see that the attitude behind it would be the originator of serious conflict. The basis of this conflict is summarized in the following extract:

Teodoro se contrarió bastante al notar en su hijo esta forma ampulosa de su vanidad; pero su disgusto creció mucho más al advertir la indiferencia con que escuchaba Simón todo cuanto él decía, hiriéndole sobremanera el poco apego que el muchacho mostraba hacia los abuelos paternos y maternos, seres de absoluta insignificancia, esparcidos por las sierras de Soria y las llanuras de la Pampa. Nunca demostró el menor interés por conocerlos, presumiendo que serían gente de baja estofa, aldeanos y gauchos, indignos de ser el tronco de aquella rama tan florida.

Cuando hablaba de su padre, usaba Simón un lenguaje semi-forense, no con el fin de demostrar su altísima sapiencia, porque de ésto, creía el pequeño Justiniano que todo el Orbe estaba perfectamente enterado, sino con la intención depresiva de patentizar una supremacía intelectual sobre el autor de sus días, chapucería que solía molestar bastante a don Teodoro Foronda, porque también éste tenía su orgullete, y reputaba tan meritorio haber venido casi desnudo a América y llegar a pescar medio milloncejo de pesos, como ser capaz de hacer un código, suponiendo, como él suponía, que su hijo fuera capaz de hacerlo al andar del tiempo. (vol. II, pp. 82-3)

The gap between the two generations widens and leads the mortified Teodoro to the following comment:

Suponen llevar en la frente un estigma, un rótulo infamativo y depresor que dice: 'Hijos de inmigrante', lo cual les duele de una manera abrumadora y mortifica su orgullo en la parte más viva, aplastando sus pujos aristocráticos y dejando maltrecha su infulosa vanidad. (vol. II, p. 131)

The emphasis of the conflict is placed entirely on the side of the older man Foronda. It is his suffering which is of interest to the novelist, who describes his unhappiness with increasing intensity: 
A don Teodoro se le desgarró el alma al proferir este último concepto ... Cuando salió a la calle sentía un nudo opresor en la garganta; una avalancha de turbias sensaciones oprimíale el corazón, y un aluvión de ideas desengarzadas, como las dispersas cuentas de un rosario, le hervían en el cerebro, chocando unas con otras, repeliéndose con empuje fabricente, cual antagónicos metales sometidos a la acción fusible de una misma fragua. (vol. II, pp. 231 and 236)

Finally, Teodoro forecasts his own sad ending:

Menos furioso, pero más dolorido, con el corazón partido por la acerada punta de una pena inmensa, el desgraciado soriano prosiguió de esta suerte: 'iQué triste y qué negro va a ser el epilogo de mi existencia! iQué final tan inmerecido va a tener mi vida de luchas y de afanes!'. (vol. II, p. 252)

In his sorrow Foronda transcends the limits normally ascribed to the immigrant and assumes precisely those qualities which, in literature, have been predominantly associated with the criollos. Displaying true grandeur, he forbears to use the threat of his fortune as a weapon against his children. On the contrary, in the midst of all his suffering, he still ensures that they shall inherit his wealth, and indeed before his end he draws up a generous will in their favour. At the moment of greatest adversity Teodoro is wholly magnanimous and what is more remarkable is that he displays these 'spiritual' qualities while remaining unquestioningly an immigrant.

Having seen that Grandmontagne adopts an understanding and benevolent stance with respect to all his immigrant characters, from the hero down to the caricaturized Pantaleón Atapuerca, (an attitude extended to the criollos, too), it is somewhat surprising to find that he is totally intransigent in his animosity with regards to second generation immigrants.

In Simón one can find all the worst characteristics ever attributed to an immigrant, even by so prejudiced an author as Cambaceres. In fact, there is much in Simón which is reminiscent of Genaro, although the purpose behind both characters is radically different, since the latter is meant to act as evidence against Immigration whereas the former illustrates the worthlessness of one who is ashamed of it. Yet it is interesting to observe that similar arguments are used to discredit both figures. For instance, Simón's appearance is said to be handsome but somewhat sickly: 'parecíase a un Apolo después de haber pasado las tercianas' (vol. II, p. 78). His eyes are likened to those of a particular night owl, un carabo, a predatory animal, and his height is compared to that of a pine, here considered planta vulgar (voll. II, p. 79). 
On the intellectual side too there is some similarity with Genaro, for Grandmontagne constantly emphasizes the poor quality of Simón's mind, which is capable of endless repetition but not of producing a single original thought:

de su cerebro estaba excluída la creación, el pensamiento original, y sólo contenía ideas sacadas del saber ajeno, o sea de los libros. Semejante a un abultado protocolo, su inteligencia prometía ser dueña de una sabiduría adquirida a título de hipoteca; pero jamás propia. (vol. II, pp. 75-6)

Describing his thesis as 'parrafadas de prosa que componían aquel monumento de la tontería' (vol. II, p. 152), Grandmontagne not only sets the seal upon Simón's pretentious stupidity, but he also criticizes the newspapers who, taken in by the rumour of Simón's adopted surname, Bolívar, praise him for the excellence of his ideas.

Simón's ambition for social preferment matches or even surpasses Genaro's in cynicism and cold-blooded opportunism. Thus, having dropped his father's surname, and capitalized on his mother's, his biggest fear remains the threatened arrival of his grandparents, peasants from Soria. For his father he feels nothing but contempt: not all the riches that he has earned, honestly, with diligence and ability, can influence Simón to feel any respect for his occupation. After an argument with him he decleares: 'él no entiende más que de percales, tramantes y percalinas. En sacándole de ahí, no sabe más. Y a mí no me discute ningún tendero' (vol. II, p. 198, my italics).

When discussing with his sister their unfortunate origins, and the need to marry into aristocratic families, Simón expresses himself brutally: 'es necesario, como te dije antes, que nosotros figuremos entre lo más selecto de Buenos Aires; es preciso limpiarnos de esta costra de inmigrantes que tenemos encima' (vol. II, p. 195). Thus, Simón wishes to rid himself of his immigrant past and therein lies his cardinal sin. In Cambaceres's novel there was no way in which an immigrant's son could alter his inheritance; in Saldías's such change was seen as a positive desideratum. In Grandmontagne's it is tantamount to treason.

For, having idealized the immigrant as the man whose qualities of hard work and sobriety have earned him just success, Grandmontagne sees it as a morally downward step for the second generation to turn their backs on their origins, and renege on their past, merely to join in a society whose faults the immigrant was called upon to improve, not to perpetuate. It is unfortunate that the conflict between the generations should have been dealt with in so arbitrary and exaggerated a fashion as in this work, but 
Grandmontagne has, at least, called attention to what was becoming a major problem. The importance of this has been acknowledged by Germán García, who writes:

Lo de Cambaceres y lo de Argerich es falso, producto de sus cerebros y de su imaginación, no de la observación directa y objetiva de la sociedad que pretendieron documentar en sus novelas. Hay mucha más realidad en los personajes de Grandmontagne, en quienes destaca una característica también señalada por otros y de la cual nos han hablado los sociólogos: la de avergonzarse de los que con su esfuerzo y su tenacidad les dieron fortuna y posición respetable en la sociedad argentina. Tal fue el padecimiento de Teodoro Foronda con sus vástagos. ${ }^{13}$

Grandmontagne does not stop at one worthless character, but reinforces his message by depicting three friends of Simón, all sons of immigrants, in an equally unfavourable light. Like Simón, they are all recently qualified lawyers, a point of some significance, relating to a trend among second generation immigrants to move away from their parent's manual and commercial occupations and join instead the liberal professions. ${ }^{14}$ The law, offering an entry into politics, was a favourite option. ${ }^{15}$

The first friend of Simón to be mocked by Grandmontagne is el Doctor Puk de Antequera, son of the Englishman mentioned earlier in this study. ${ }^{16} \mathrm{He}$ is an insensitive youngster, materialistically orientated who, to his parents' disappointment, can show an interest for nothing other than railroads and cattle: 'aquel joven no vibraba sino ante los actos que procuden oro; el mejor poema que podía colocarse en sus manos era una letra de cambio' (vol. II, p. 158).

The next to be discussed is el Doctor Sonajas, a young man who came from the provinces, where he had already made his political debut in various electoral skirmishes, fighting and even killing a chief of police in self defence: 'en su figura moral hay algo de asqueroso y repelente; es el criminal vulgar, que si no le amparase el manto encubridor de una política localista, arbitraria e inculta, viviría arrastrado un grillete en el patio de un presidio, confundido entre los más degradados delincuentes' (vol. II, p. 159-160).

Langredo, the last of the three, was something of a wastrel and a playboy. He was really drawn to the world of literature and of ideas, yet he, too, became a lawyer for opportunistic reasons: 'le tenía muy poca afición a la carrera, y sólo la abrazó por lucimiento, a fin de utilizarla como una especie de peón caminero para abrirse paso y escalar otras cumbres más empinadas que las del foro' (vol. II, p. 170). 
In Teodoro Foronda, criollo characters play a purely secondary, supportive role. Yet it is interesting to note that in the one work written by an immigrant author, it is the criollos who emerge as a materialistic and also opportunistic people. Thus, a reversal has taken place, and the materialism of the age, which other authors decried and attributed largely to the immigrant invader, is seen here as a characteristic of the native population itself. Not of the semi-barbarous gauchos, but of the city people, who sacrifice everything to progress and who seem only too eager to participate in the winnings. Corruption seems to be the norm, and it is highly significant that in the partnership of Foronda, Vicharo y Cía., the immigrant is the honest partner, whereas Vicharo is the one who bribes the officials and knows how to handle the all-important officers at the Customs. He is not, however, presented as a villain ('era Vicharo una excelente persona', vol. II, p. 22); on the contrary, he is praised for his charming ways and his gift in dealing with all sorts of people. If he lacks Foronda's probity, it is because he is more in tune with a system which is itself corrupt:

Todas estas relaciones constituían el capital más valioso con que don Carlos Vicharo concurría al progresista desarrollo del registro, en el cual, además de intervenir en su marcha general, cuya dirección asumía Foronda siempre de acuerdo con él, desempeñaba tres cargos especiales y muy importantes, a saber: el manejo absoluto de los asuntos aduaneros, para lo cual tenía empleados formados en su misma escuela; la representación de la casa en los Tribunales, a fin de activar todos los expedientes por cobros a los morosos, quiebras y otros percances comerciales, que resolvía en unión de un abogado íntimo suyo, y cuyo talento jurídico consistía en una estrecha amistad con los jueces.

También se hallaba a cargo de Vicharo lo que llamaremos dirección política del registro. Nos explicaremos con mayor claridad. Cuando algún politicastro barullento y afecto al sonsonete de las inconscientes manifestaciones públicas, necesitaba el apoyo moral del comercio para ocupar un alto puesto, Vicharo era el resorte o la piedra de toque, para mover a nuestro cosmopolita mundo mercantil, y Foronda la palanca ostensible para producir el movimiento. (vol. II, p. 20)

Given Grandmontagne's highly prejudicial and inconsistent attitude to women, it is difficult to draw a strong conclusion from his criollo female characters. Thus, the two women who are given a certan amount of prominence in Volume II, display totally opposite qualities. They are Purita, Foronda's mistress, and Doña Paca, her chaperone. Both were taken out of a brothel by Teodoro. Paca, the older one, is a grasping and calculating female, seen here trying to persuade her 'ward' to extricate some money from Foronda: 
-iAndáte al cuerno! No servís para nada. Sos una grandísima tonta, ¿Que no sabés cómo decírselo? iVaya una salida! Pues es lo más fácil. Con un poco de maña, todo se arregla enseguidita. Pero vos no sos baqueana en estas cosas, y te asonsás al momento. Atendéme y verás si es sencillo. Un día, cuando venga con la buena, ¿sabés? cuando no esté alunado y ande con ganas de hacerte caricias y esté muy meloso ... ¿me comprendés lo que te quiero decir ...?

- Sí señora. Ya la comprendo.

-Pues güeno; cuando se ponga hasta cargoso de puro amable, vos te echás a llorar. Enseguida te preguntará él por qué llorás, y vos le decís, llorando más fuerte, que te querés morir el mismo día que él se muera. Ésto le ha de parecer extraño, y, por de contado, te preguntará la causa. Entonces le decís vos que te quisieras morir el mismo día porque después no podrías seguir viviendo ... No vayas a decirle que por falta de plata ... iporque vos sos tan sonsa! ... sino de pena, ¿sabés? de puro sentimiento. Está claro, a él le dará lástima, le entrará, ¿sabés? ese chucho poético que le acomete cuando le mentan cosas tiernas, y de seguro te dice que vivás, aunque él se muera, porque, al fin, ningún empeño puede tener él en que vos espichés ... Y ahora viene lo güeno, lo principal del asunto, la pechada, ¿sabés? ... (vol. II, pp. 115-16)

She is a picturesque character, and her lively comments on the immigrants are a revelation of resentment and prejudice:

-Las costumbres están desconocidas, - indicó doña Paca. -iVieran ustedes allá en mis tiempos! Daba gusto vivir en Buenos Aires. Todo el mundo vivía a la crioya; pero ahora, con tantos extranjeros, ingleses, franceses, españoles, italianos y el diablo a cuatro, es una verdadera confusión.

-Dígame, doña Paca: ¿de qué nacionalidad son los del diablo a cuatro?preguntó Teodoro festivamente.

-Quiero decir los gayegos, los napolitanos. i Ah, los napolitanos! Nolos puedo ni ver...

- ¿Y por qué, doña Paca?- preguntó riéndose Purita. -iLos pobres son tan alegres! Siempre están cantando y mirando al cielo. Ponen un adoquín, y en seguidita miran hacia arriba. iSi son muy buenos! Y cuando barren las calles, ipobrecitos! parece que bailan tarantelas.

-iCayáte, hija, cayáte! Cuando caminan parece que van pisando huevos. Y luego, ison tan tacaños ...! Atendé una cosa: yo nunca les he visto comer más que pan y ceboya ... También he oído decir que se comen los cabos de la velas de sebo. iHijita, si es una cosa tremenda! ... Al centavo que cae en sus manos, ya le pueden echar un galgo. Se lo meten en el abujero de la pata del catre, y adiós; nadie lo güelve a ver. Si les barrienaran las tripas, no les habían de sacar más que miseria. (vol. II, p. 45)

On the other hand, Purita, aptly named, is the epitome of selfabnegation and disinterested, undemanding love. In contrast to Simón's disrespect, she will not accept Foronda's offer of marriage because she feels unworthy to carry his name: 
- Decime Purita- preguntó Teodoro, poniendo una mano en el respaldo de la silla y otra en la mesa, de modo que la dama quedaba bajo su pecho. -Decíme: ¿te casarías conmigo?

-Nunca- respondió la uruguaya con seguro tono.

Don Teodoro quedóse perplejo por unos instantes. Al fin, dijo:

-Entonces ... ino me quieres?

-Sí te quiero ... icon todas las fuerzas de mi vida!

$-¿ Y$ por qué no aceptas ser mi esposa?

-Porque no soy honrada- dijo Purita, roja de vergüenza y a punto de romper a llorar.

- Para mí lo eres, tanto como la santa más grande del calendario.

-Para vos lo seré; pero no lo soy para el mundo-repuso ella tristemente.

........

-Me creo indigna de tu nombre, y estoy dispuesta a vivir toda mi vida como hasta aquí (vol. II, p. 279)

There is less good-humoured benevolence in Grandmontagne's handling of the native inhabitants of the estancias neighbouring Añahualpa. Racial prejudice, one of the principal components in the conceptual framework of the Immigrant Novel, is a prominent feature of the following description about the gauchos:

el gaucho, medio enmascarado con su pañolón de colorinches, el chiripá desgarrado, las barbas como púas de erizo, mirando siempre de soslayo y con desconfianza indígena; la china de los primeros ranchos, indolente, sucia, rotosa y desgreñada, despidiendo cierto tufillo subterráneo y montuno, como los conejos; el seno caído, igual que el mondongo de la cerda, al aire las piernas, atestadas de mugre; medio idiotizada, por la falta absoluta de disciplina moral; siempre bamboleante, siempre si se cae o no se cae, de puro haragana, y constantemente tirada por el suelo, cual si fuera un fardo de huesos. (vol. I, p. 74)

The author had spent some years in the rural areas of Buenos Aires Province and had, no doubt, encountered families who lived in the primitive conditions which he describes, yet the tone of his narrative, the vocabulary used, and the repetition of stereotyped concepts, betray his racist stance.

Yet it is interesting to note that, as with Argerich's inconsistent handling of his prejudice against Immigration, Grandmontagne does not uphold his views on the gaucho for long, and when he comes to deal with the individual, he ends up by praising him. The inconsistency in the portrayal of María has already been noted: from an insensitive brute she became an admired, suffering saint. Less dramatic, but also indicative of the superficiality of Grandmontagne's views on the gauchos, is the change undergone 
by María's father, Don Leandro Bolívar, who is introduced as being little better than a filthy, indolent, though loyal, animal. He is referred to as:

este animal bípedo, que por sólo su forma externa, se empeñan los racionalistas en que ha de llamarse hombre, gauchote destartalado, reñido con el aliño, que más que andar, arrastraba los pies, indiferente a cuanto significara comodidad y limpieza, indolente y perezoso como una tortuga, pero muy fiel y muy honrado. (vol. I, p. 107)

His home is described as follows:

Cinco eran los engendros de aquel ayuntamiento; dos hembras de quince y doce años, y cuatro varones de siete para abajo, en tan miserable estado estos últimos, que parecía hubieran sido transportados allí por el propio carro de la basura. La dejadez de la madre, se reflejaba en aquellas criaturas, donde la alfalta brotara exuberante, si alguien hubiera derramado en ellas la semilla. (vol. I, pp. 109-10)

Yet, contrary to the empty, fulsome phrases of condolence expressed by the educated people of Añahualpa on the occasion of María's death, he is the only one whose words are said to contain the wisdow of nature:

La mayor parte de los añahualpenses, incluso aquellas personas de remilgada moralidad, acudieron a prodigar al viudo frases de consuelo, llenas de lugares comunes, rancias y vulgarísimas, siendo oídas por Foronda con marcada indiferencia, como se escucha casi siempre ese formulismo tonto y frío, que está en abierta riña con la sinceridad y que sirve para expresar sentimientos no sentidos y ofrecer cosas que no se tiene ánimo de dar.

El que mejor y más oportuno y sincero estuvo fue D.Liandro, que al encararse con su yerno, le dijo sencillamente y con viril entereza: 'Paciencia amigo Foronda: la muerte es una veleta que tan pronto apunta a un lado como a otro. Al dolor, sólo le mata el tiempo. Ya todo es inútil para nuestra pobre María, y no hemos de ser maulas poniéndonos a llorar. El llanto no riega, agosta ... (vol. I, pp. 303-\%)

Having analyzed the important characters of this lengthy work, it remains to draw attention to what is perhaps the most prominent immigrant character, not only of Teorodo Foronda, but of all the novels under review. This is the author himself who, by his choice of material and by the direct comments with which he intrudes in the novel, has become the most interesting observer of the social scene of Argentina. ${ }^{17}$

It is noteworthy that Grandmontagne, himself an immigrant, felt sufficiently at ease to criticize his adopted country in many aspects. His attitude towards America is less fulsome than that encountered in other writers of 
the times, such as Saldías, Sicardi and Ocantos. ${ }^{18}$ Grandmontagne sees it as a land offering great possibilities of advancement and says so without feeling the need of succumbing to a eulogy of its spiritual grandeur. For him this is not only the land of opportunities, but also of opportunism: 'Escucha: en América hay que ser trabajador y atrevido. Más de esto que de lo otro' (vol. I, p. 25).

The idea, encountered in Alberdi, that man deteriorates in America both physically and intellectually, is given here in reverse. Grandmontagne writes:

América ilustra y enriquece al mismo tiempo. El esfuerzo humano vale aquí doble que en Europa; los muchachitos como tú, rudos, fuertes y montaraces a semejanza de los jabalíes, son aquí millonarios en canuto. Espera sin impacientarte. Trabaja y no divagues. Lucha cuerdamente, y verás que el porvenir te reserva algo más que ser un miserable jornalero, con pespuntes de sacristán como tu padre. (vol. I, p. 60)

This thought is repeated by one of the characters, who declares:

y es, que aquí en estos países, cuna futura de los nuevos moldes en que ha de encerrarse la vida del Universo, aprenden los muchachos una clase de filosofía, o dígase si se quiere, gramática parda, que deja muy atrás a la que se enseña en las vetustas Universidades europeas. Los jóvenes, procedentes de nuestras montañas, púlense aquí sin sentir, adquiriendo la suficiente preparación para ser paladines en la desaforada lucha por la existencia. Dijérase que el despejo se lo mete en el cráneo el sol de los trópicos y el vientecillo de la rasa pampa, en consorcio con las forzosas enseñanzas de la necesidad, que es consejera insuperable y del aguijón del estímulo, que excluye la perezosa modorra hasta de los temperamentos más linfáticos. (vol. I, pp. 247-8)

But the praise of climatic and environmental conditions in America is not, as in Bianchetto, something that points to a spiritual aggrandizement but to a physical improvement which develops possibilities for social and economic advancement. Thus, the narrator concludes with the assertion that in Spain, Foronda would have remained an uncouth labourer, whereas in America he will achieve fame as well as riches.

The praise of America for its material opportunities is in keeping with the general ideology of the work. Thus, not only is hard physical labour valued but, more unusually, the practice of commerce is held in high esteem. Once more, the comparison with Bianchetto springs to mind, for in the only other novel examined in which the immigrant features in a positive light, he feels constrained and unfulfilled when only a salesman, and becomes an estanciero instead. Here, commercial practices are described objectively, without adopting a superior tone, even when relating certain 
tricks such as coercing unwilling buyers, running down the opposition's stock, or avoiding tax payments. Indeed, characters are praised for their success in this field.

Discussing the recently formed Club del Progreso of Añahualpa, the author points out that all the different races mingle there, united by the common bond of commerce. The following sentence is said not with sarcasm, but to underline the spirit of cooperation that exists in the world of commerce: 'entre los habitadores de nuestros pueblos no hay más que una religión, que es la del comercio' (vol. I, p. 145).

The portrayal of Añahualpa is a valuable literary document of life in a small but commercially prominent town. Its sadness and lethargy is keenly felt by Teodoro as he enters its empty streets, and Grandmontagne seems to have captured the atmosphere of the place in his descriptions:

Algo extraña y aun lúgubre parecióle la entrada del pueblo, aunque, propiamente dicho, nuestros pueblos no tienen entrada determinada, y se puede entrar en ellos por todas partes.

Las descarriadas casas, que parecían estar reñidas unas con otras; aquellos caminos solitarios y tristes, que se estremecían por el lejano trotar de los caballos; los árboles desamparados y llorones, corpulentos y añosos cual el roble, y, a semejanza del ciprés, melancólicos, siempre verdes y con sus ramas colgando, como si fueran los pingajos de la orfandad desheredada; los secos y carcomidos postes de ñandubay, en cuyas puntas había posados algunos pajarracos con ojos de persona y uñas de cuervo, el pico metido entre las perezosas y cenicientas alas, y durmiéndose, igual que los atorrantes, al calor del sol, después de haberse hartado con la carnaza putrefacta y pestilente de los jamelgos muertos a uno y otro lado del camino ... (vol. I, pp. 73-4)

In this town criollos and immigrants are seen to coexist peacefully, the latter being in charge of all commercial activity. This is described in minute detail regarding the buying and selling relationship with the native customers, the services provided by the village stores, and the general turnover of the firms. This must have been considerable. The author writes:

Bien lejos estaba de imaginarse que en aquella aldea, por cuyas calles cruzaba alguna persona cada media hora, hubiese un movimiento comercial mucho más importante que el existente en toda la provincia de Soria, y que cada casucha de aquellas valiese más que la Iglesia parroquial de su pueblo. (vol. I, p. 74)

Whereas many writers, from Sarmiento to Sicardi, have praised commerce and industry in theory, Grandmontagne is the only one who illustrates this approval by creating in Teodoro Foronda a fictional character who is admirable and yet a business man. 
In view of the utilitarian values examined so far, it is not surprising to find in Teodoro Foronda a loud and eloquent disdain of lawyers. (This subject has been touched upon in connection with the second generation of immigrants.) All the ills of the country are attributed to them: 'la plaga de enredadores que anualmente salen de la Universidad, para mal de la política, de la administración pública y de la paz del país' (vol. II, p. 29).

Any disparaging remark made about Foronda's son Simón, the most unpleasant character of the story, is usually accompanied by some sarcastic remark concerning his legal connections, such as: 'la esclarecida gloria forense' (vol. II, p. 252) or 'el insigne jurisconsulto' (vol. II, p. 193). This hatred of lawyers is due not solely to the essentially unproductive nature of their work; it is related, too, to the close alliance that exists between this profession and politics in Argentina. On this, Grandmontagne makes the following biting remark: 'entre nosotros, la palabra abogado significa la posesión absoluta de todas las aptitudes para el mangoneo de la cosa pública. Es el gremio monopolizador del poder y de la administración, salvo los huecos reservados al militarismo insubordinado y prestigioso' (vol. II, p. 148).

There are several examples given of political abuse and corruption; some are general remarks, others aim at particular politicians. On bribery and corruption Grandmontagne refers to: 'nuestra administración pública, por cuyo organismo corre una jocosidad truhanesca, que presenta a la burocracia como al más acabado modelo del bandolerismo de levita' (vol. II, p. 19).

Earlier on he had attacked the ex-President of the Republic with indirect sarcasm:

El sombrero es el que presentaba un estado lamentabilísimo. No eran muchos los agujeros que tenía; pero sí suficientemente grandes para que por ellos pudiera salirse todo el talento político y sagacidad bancaria que el doctor Pellegrini alberga en su cabeza. (vol. I, p. 19)

It is true that remarks of this nature had become almost a literary cliché in the contemporary novel, but Grandmontagne's repeated attacks seem to cut more deeply than mere literary fashion. The autodidact also has a great deal to say on education. Although he thinks that it is better in Argentina than in Spain, he criticizes the fact that it consists largely of memorizing received opinion rather than of developing the student's ability to think creatively: '... siendo el sistema de enseñanza meraments retentivo, los profesores clasificaron de sobresaliente el saber de este renacuajo de la legislación' (vol. II, p. 82). 
Female education, according to Grandmontagne, seems to be entirely geared towards the social graces with no concern at all for academic achievement (vol. II, p. 90). His attitude to women is patronizing and inconsistent. All the stock arguments are voiced: thus, women are said to be either weak or resilient; evil seductresses or soft, self-sacrificing creatures; calculating and materialistic or disinterested and selfless. They are presented either as victims of a male-oriented society or, contrastingly, as ruthless creatures who selfishly use all around them to further their own ends.

The author, whose style has been compared to that of Pereda, is interested, like his Spanish compatriot, in observing popular speech. ${ }^{19}$ He makes a feature of recording local sayings and regional accents, as illustrated by the quotation from Doña Paca's lecture to Purita. He notes the practice of yeismo, by which the Spanish lle sound is pronounced in the River Plate region as ye. He also observes the usage of seseo (instead of the Castilian ceceo) in that in dialogue Guriezo is always addressed by the locals as Gurieso. He also notes the use of voseo, or use of the familiar vos instead of tú, current in most parts of Argentina and Uruguay. Semantic differences between Peninsular Spanish and Argentine Spanish are frequently pointed out, particularly by the newly-arrived and bewildered Teodoro. One amusing incident told, is the following:

-Pues tenés que andar ... una ... dos ... tres ... cinco cuadras.

-Cinco ¿qué?

-Cuadras. ¿No sabés lo que son cuadras?

-Sí señor ... pero en las calles ...

(vol. I, p. 28)

The dialogue exemplifies the different use of the word cuadra, meaning a block of houses in Argentina and a stable in Spain.

Thus, it can be seen that accompanying the fictional element, of which Teodoro's life story is the mainstay, there is in this work an acute and sensitive observation of society, justifying the subtitle of Evoluciones de la Sociedad Argentina. The documentary importance of Teodoro Foronda has been pointed out by Germán García, who writes: 'No es la primera donde aparece el inmigrante, pero Teodoro Foronda, la novela de Francisco Grandmontagne, es la que ha quedado señera por su valor documental y puede ser la que más perdure. ${ }^{20}$

To conclude, therefore, it can be said that in Teodoro Foronda one finds not only the depiction of the impact of Immigration upon many sectors of Argentine life (particularly that of commerce) but also the impact of 
Argentine life and society upon the immigrant, here represented by fictional characters and by the narrator. This is what makes Teodoro Foronda the most complete portrayal of Immigration. It is the one work which is most faithful to a situation which no other writer at the time sought to tackle, i.e. that of the immigrant himself.

From the purely literary point of view the double perspective poses problems of organization and coherence which at times seem to surpass the author's capabilities. There are inconsistencies, exaggerations, endless digressions which, it can be said, mar the effect of much of the novel as such. Yet, merely by its unique presentation from the vantage point of the immigrant, in addition to an objective account of the changes brought about by Immigration, Teodoro Foronda deserves to be considered a memorable contribution to the literature of the period.

Within the categories of works whose overall attitude towards Immigration is favourable, Bianchetto and Teodoro Foronda stand at opposite ends. In the first, the immigrant is idealized because he adapts to new ways and becomes a criollo, in the second because he retains his immigrant's quality. In Libro extraño, the last work to be examined, a fusion of both possibilities occurs. 


\section{IV * "LIBRO EXTRAÑO"}

This last chapter seeks to examine the portrayal of Immigration in the cyclical series of novels written by Francisco Sicardi between 1894 and 1902 , and published under the title of Libro extraño. Although there is some confusion as to the presentation of the individual stories, the work is generally divided into the following sections: Libro extraño, Genaro, Don Manuel Paloche, Mendez and Hacia la justica. ${ }^{1}$

Sicardi was born in Buenos Aires in 1856, of an Italian father and an Uruguayan mother. He spent his formative years at school in Italy, and then studied medicine at the University of Buenos Aires from where he graduated in 1883 . He practised his profession for a number of years, but eventually gave it up in order to write. From his work, it can be seen that in him the romantic poet and the man of science were always at odds, since there is a basic underlying tension between his nostalgic, sentimentalized vision of humanity and some of the harsh scenes of social misery and exploitation which he records.

Libro extraño is a mammoth work which runs to over a thousand pages. Although a great part of it is not directly connected with the portrayal of Immigration, its plot symbolizes the transformation of Argentina from primitive society to modern state, and the object of the present study is to examine the role ascribed to Immigration in the telling of this change. The story follows the interrelated lives of three generations of families who represent different social groups. At the top of the social ladder lies the patrician household of Dr Carlos Mendez and his wife Dolores del Río; they are on friendly though not equal terms with Don Miguel Paloche and his middle class family. Paloche, who is a failed doctor and a failed poet, but a man of vision, is presented as a forward looking character, in favour of Evolution and an advocate of Immigration. The Mendez's employ and protect the members of the low class family of Genaro, an honest loyal servant whose downfall is caused by yet another doctor, Enrique Valverde. The latter is not so much the representative of a social class as the embodiment of evil. This denotes that social division is just one way in which the characters of Libro extraño can be grouped. Another would be on moral grounds, with saintliness fighting against corruption and evil.

Libro extraño is also noted for its picture of physical and mental abnor- 
malities, depicted in a list comprising syphilis, tuberculosis, epilepsy, alcoholism, mystical hysteria, nymphomania and homicidal psychopathy. The work also includes some idealized figures of physical and spiritual rectitude such as Catalina Mendez, Dolores del Río and her illustrious father who fought in the Wars of Independence. They, with Genaro's old mother, are remnants of a past age who, towards the end of the novel are replaced as the representatives of an ideal by a new generation, one which has been invigorated and perfected by the integration of a new race of immigrants. In a fusion so symbolic that it lies at the crossroads of anecdote and ideological discussion, Angélica Mendez, the daughter of the Argentine élite, marries Elbio Errécar, the son of an exemplary Basque immigrant, and it is in their issue that the author places the hope of a noble and prosperous Argentina.

At the fictional level of this work, the portrayal of Immigration has been kept to a minimum, with only a few immigrant characters mentioned until the arrival, in the last book, of Martín Errécar and his wife. Until then, immigrant characters were confined to an Italian policeman who speaks not a word of Spanish, an Asturian tram conductor, an Englishman who holds a speech on the British, and anonymous members of a crowd who eventually break out in open revolt. (This incident will be analyzed in another context.)

Martín Errécar, the first and only immigrant character of importance, appears, as mentioned, at the beginning of the last book, Hacia la justicia. He symbolized the ideal immigrant, the man who obeys the material dictates of hard work and economic advancement, but is not devoid of a spiritual dimension as shown by his love for his family. His presentation is worth quoting in full for its quality as an ideal proposal:

Era sencillo y fuerte. Cuando vino de Europa, muchachón de veinticinco años, tenía el pecho robusto y los brazos musculosos, muchas esperanzas y el alma bravía. Agachado sobre su banco de carpintero, cepillaba todo el día y se la veía darle a la sierra arriba y abajo, serruchando tirantes y alfajías. No gastaba. Nunca se acercó a los almacenes, ni jugó. En las horas de descanso, cuando llegaba la noche, su talento de narrador jovial entretenía a los compañeros. Poco a poco, merced a los ahorros, pudo comprar un taller para trabajar con más bríos. Se enamoró de una mujer y se casó, no sin que esta pasión despertara en él algunas sensaciones de artista. Escribía versos para ella, unos pobres pensamientos que le brotaban de la pluma sin ningún arte, con la fluidez límpida de un manantial. Eso nadie leía sino la compañera de su vida, para la cual, aun muchos años después, tenían misteriosos encantos aquellos papeles amerillentos guardados en la cómoda. Trabajaron los dos hasta comprar un terreno. Sobre él edificó una casa de madera, donde nacieron sus hijos, y a medida que ellos crecían, en el alma del padre entraba hondo el 
cariño por la tierra hospitalaria, tanto, que al recordar a veces la nativa aldea, los dos amores se confundían y se estrechaban en una sola idolatría. (vol. II, pp. 403-4)

In his model immigrant Sicardi combines the virtues of the materialistic ethos with emotional and poetic sensibilities. Martín is serious, hard working, thrifty and successful, and in this respect conforms to the stereotype image of the immigrant encountered so far. But his portrayal surpasses that of the stereotype in its 'spiritual' aspirations. The lyrical vein in Errécar which expresses the purity of his love both for his wife and for his new country, is an indication of a potential nobility. His life becomes intertwined with that of Carlos Mendez when his small son takes ill and the compassionate doctor tries, in vain, to save him. A strong friendship is born between the two men which overcomes all cultural and economic distances, laying the foundation stone for the eventual union in marriage of the old order and the new.

As a literary figure, Martín Errécar remains a purely rhetorical device to present an idealization. With its allusions to healthy athleticism and comparisons with orchestral music playing, there is little connection with the world of objective reality in the following summary of his life as a worker in Argentina:

Era su triunfo. Él había sido el atleta del taller, el alegre artista de aquella orquesta del trabajo, el creador de las estridentes y hercúleas sinfonías. Por eso amó sus herramientas, como el guerrereo viejo la espada de acero. Casi sin querer, cuando las limpiaba hasta dejarlas lucientes, años tras años, iba recordando su pasado tan sereno y tan lógico, hasta producir el bienestar del presente. Un día después de otro, ocho o diez horas, pero todos los días; sin desertar jamás, sin huelgas, paciente y pertinaz, como uno de tantos laboriosos de esos que construyen ciudades y fecundan campos. Así se envejeció Martín Errécar y así educó a sus hijos. (vol. II, p. 506)

His son, Elbio, is the only second generation immigrant character of any note, with the exception of Genaro. But Genaro's immigrant ancestry is referred to briefly, and discarded in the development of the story. His father's country of origin is not specified, but as Luciano Rusich points out, there are indications that he was Italian in the use of the word Madonna to describe a picture of the Virgin on his mother's bed and in Genaro's own name, common in Italy and particularly in Naples, whose patron saint is so called. ${ }^{2}$ The description of the father's birthplace as a typical Mediterranean fishing village, and the reasons why he had to emigrate, are all details which point to Italy. Yet he is always referred to as tata, a typically criollo word for father, and one which would not be readily used in the 
context of an immigrant family. Nor does Genaro behave as a typical immigrant's son, sharing none of the problems or characteristics normally associated in literary typification with this group. On the contrary, at first he epitomizes the faithful criado, the loyal servant traditionally born and raised in the household of his masters. In his later days, after his dismissal from his job, he becomes the soul of the underworld, an arrabalero and $a$ compadrito $^{3}$ whose guitar playing evokes with nostalgia the passing era of the gauchos, lawless, proud, and ever-ready for a knife-fight:

Las cuerdas de la guitarra suenan; Genaro canta. Es el alma de los suburbios que se desata y se estremece en la estrofa de esa poeta inculto y primitivo. La bordona llora con su voz grave, las hondas y desordenadas pasiones de estos lugares, como si eso fuera la evocación de épocas ya perdidas para siempre, y vibra y palpita bajo el dedo agitado como si fueran ímpetus de la prepotente bravura de estos hombres. Después resbalan los dedos rápidos unos tras otros sobre las cuerdas tendidas, y no es armonía entonces lo que se oye, sino chasquidos y choques con disparadoras chispas y rechinar agudo de hojas de puñal. El corazón hueco de la guitarra retumba. Son tormentas que pasan, boquetes de relámpagos que se abren y se cierran en el cielo irritado y negro, rimbombos y tableteos lejanos de centellas en fuga, estrépitos y rugidos de huracanes que se encajonan y bellaquean entre los callejones de las quintas. (vol. I, p. 343)

In the prologue to the last book, after Genaro has been dead for some years, he is remembered once more as the soul of unspoilt criollo values before the changes of immigration took hold of the city and its surrounding areas (vol. II, pp. 390-1).

In the light of this it seems erroneous to place any emphasis on Genaro's immigrant ancestry, other than to point out its ephemeral role in the story. The conclusion reached is that in the lengthy and richly populated story which Sicardi uses to illustrate the development of Argentine society, there is a minimum of immigrant characters, and none who is developed as an individual figure. This last point gains relevance if considered against the author's undoubted ability to create criollo characters who, while idealized and exaggerated, can be remembered by their strong personality and individualizing traits.

The reason for a wide gap existing in the amount of interest shown in the presentation of criollo and of immigrant characters lies in a basic difference of purpose. In the absence of precise information, it may be conjectured that a work such as Libro extraño would have been written for a small public that was predominantly criollo and whose interest had to be held by the author before he could succeed in expounding his ideology. 
The fictional element of Libro extraño therefore exists as a backdrop to the message. Instead of both parts being woven together so that the fiction illustrates the message (as was the case in, say, En la sangre or in Bianchetto) each side of the work is kept separate, The story which evolves around the criollo household of Dr Mendez has primarily an aesthetic intention and is told to entertain the reader. That small section of it which concerns an immigrant family is there to instruct, its aim being to provide an example of the merits of Immigration, but this is done in a simplistic, undeveloped manner. Thus against the rich canvas filled by characters such as Mendez, a homicidal psychopath, the eccentric and deranged Paloches, the sinister Enrique Valverde, Genaro, the homicidal alcoholic and Goga, the nymphomaniac with a pure heart, the marmoreal portrayal of Elbio Errécar lacks vigour and interest. His appearance is delayed in the story until the final section, his role in it is merely functional and his description liefeless, rhetorical and idealized:

Elbio era un sano, de pecho levantado y pulmón amplio, de corazón fuerte, con ritmo lento y robusto. Su piel blanca, un poco gruesa y áspera, una piel sin manchas, involucraba el armonioso cuerpo de hombre vigoroso y alto y los relieves del músculo. De ojos grandes y obscuros y de mirar dulce y amable, adquirían aquéllos extraordinaria agudeza en presencia de la injusticia. Sobre su frente marmórea y nítida, nunca una arruga amarga, nunca una contracción de alma indecisa, y en toda su cara de plácida bondad, jamás una mueca de desprecio, ni relámpagos de orgullo, antes mas bien la serena luz resplandecía de su alma caritativa. Era un sobrio y un casto. (vol. II, p. 528)

Elbio is not simply another character but the representative of an existing race and the foundation stone of a new one. The two other descriptions of him are effigies of a hero. The first occurs when he is staying the crowd from breaking into the mansion of the Mendez family (vol. II, pp. 520-1). The second takes place when he is about to proclaim his political credo (which will be analyzed more fully in due course):

El médico estaba parado en un banco. Dominaba ese mar inquieto de varoniles cabezas. Su voz era vibrante. Había algo de gigantesco en esa historia, narrada así con sencilla palabra, en esa historia de salud moral que había creado una ciudad y forjado un alma inmortal. Sin quererlo se había transformado en un conductor de razas. Era un selecto de cuerpo, una blanca estatua de varón fuerte, un corazón de sangre incontaminada y una sana integridad de intelecto. Amaba a los trabajadores y los guiaba hacia la justicia.

-Eso es- contestó irguiendo su cuerpo y levantando la mano al cielo. -No pertenezcan a ninguna asociación. iNi católicos, ni socialistas, ni anarquistas! Hay algo superior a todo eso: iser libres! (vol. II, p. 573) 
Having established the almost complete absence of immigrant characters at the aesthetic level of Libro extraño, it is curious to find that Immigration plays not only a fundamental, but largely a positive role in the ideological content of the work. Its presentation is concentrated chiefly in the third book, Don Manuel Paloche and in parts of the last, Hacia la justicia. Underlying Sicardi's work as a whole there is a constant tension between the unsophisticated, static values of the traditional colonial past and the materialistically orientated values of the present, preaching economic evolution and inevitable social change. The dichotomic view that Sicardi takes of the problem is reminiscent of that which Sarmiento had adopted, half a century earlier, and condensed in his famous saying 'Civilization and Barbarism'. Not only do the same attributes operate with respect to each end of the formulation, but, as will be seen, a similar element of ambivalence to that which was found in Sarmiento's work, is evident in Libro extraño, but with increased complexity.

The struggle between civilization and barbarism is placed, in Don Manuel Paloche, in the context of an impending revolution, whose crowds are swayed in opposite directions. This section is probably set in the decade of 1880-1890, and the revolutions mentioned could be said to represent the turbulences which took place in 1880 and in $1890,{ }^{4}$ but there is no specific mention which would point to a particular historical event. Instead the revolution is shown to be the struggle of opposing factions of which one is formed by the native masses who wish to preserva their old habits and take violent revenge for their past sufferings at the hands of exploitative masters:

Ha llegado la hora de la venganza, y los sepulcros levantan sus tapas y la boca obscura está pronta para tragar a los contaminados. Giran y corren los sepulcros por los sitios de la pelea y arrebatan en su cavidad podrida a los que defienden la crápula y han muerto. Allí van a encerrarese para siempre con los dineros robados, con sus afrodisias sensuales, con las sedas y el cuerpo lúbrico de las rameras que han disipado en la orgía los ahorros de los trabajadores honestos. iMejor es que mueran! Si no el pueblo los va a estrangular con mano feroz y prisioneros sobre minas de pólvora sentados van a volar en pedazos. Han hecho llorar los hogares por la pobreza acercados al lupanar. iAy de ellos! Puede faltar el pan y en el seno de Dios, los hombres de hambre morirse, pero pobre de aquél que da escándalo y coloca a la inocencia cerca de la deshonra. Las iras del cielo han de aventar la ceniza con la basura impía. (vol. II, p. 142)

The other faction is that formed by the recently arrived immigrants whose wish is for peaceful conditions to enable them to fulfil their dream of prosperity for themselves and their adopted country: 
Todas las razas habían soplado sobre ellos sus idiosincrasias conservadoras. El inglés boxea; los franceses juegan la partida con formidables coups de sabatte; algún sombrero vuela impelido por un puntapié cancanesco; los vascos toman de pelotas a los cráneos a revés limpio no más, o descargan la macana que suena fofo como sobre calabaza huera; se ve brillar una que otra navaja sevillana entre los amigos de la revolución, mientras el estileto gira con resplandor carbonario, defendiendo al orden. (vol. II, p. 80)

One of the leaders is Desiderio, the self-appointed defender of the criollo masses, preaching violence and resistance against the newcomers and all the forces of change. As in Facundo, there is a quality of satanic dynamism in the caudillo's commanding presence, but, whereas in Facundo's portrayal there lurked the danger of a living enemy, Desiderio is an obvious allegory, powerless and therefore idealized:

Desiderio, con la galera echada atrás y envuelto en su poncho vicuña de largo fleco, lleva a la muchedumbre a la pelea. Está pálido y flaco; pero su voz caliente enardece y agita. Cruza los treinta años. De rostro enjuto y pómulos salientes, tiene color moreno y ojo grande y vivísimo. Alta la persona. Sus movimientos, rápidos. Alma vibrante con energías hasta el heroísmo y generosidades hasta la miseria suya; por eso su mansión de rico heredero se transformó en tugurio. Un batallador con capacidad moral para el martirio. Su casa es de todos y a su mesa se sientan los pobres; sus dineros son de los demás; sus ropas visten, en los inviernos sin sol, carnes de miserables. (vol. II, p. 105)

Desiderio represents the last of the caudillos, and the epitome of La indole que muere. ${ }^{5}$ Defeated, his epitaph is the following: 'el futuro ha perdonado a Desiderio. Él no sabía que la turba que lo acompañaba a su casa con cualquier motivo, era apenas una parte del viejo país' (vol. II, p. 113). Thus, once it has become harmless, la barbarie may be remembered with poetic nostalgia.

The immigrants are defended by Don Manuel Paloche, the man who holds ideals of peaceful evolution towards a modern industrious state. He is an inconsistently drawn figure who is caricaturized for his grotesque eccentricity yet, who in this section often becomes the author's spokesman, assuming his voice and expressing his ideas. These are not always clear since Paloche moves, within one paragraph, from one argument on to another. He mixes, for instance, his contempt for heroic action with faith in evolution with a concern with hygiene: ${ }^{6}$

-Si me oyen el pensamiento- se dijo para su caletre,-me lapidan estos amables ciudadanos. Así me parece que voy a concluir de repente, porque a pesar de mis idiosincrasias aborígenes, sigo creyendo que muchos heroísmos son errores. Pero yo he de modificar la conciencia nacional- dijo en alta voz don 
Manuel, encarándose con el primero que pasó a su lado. Este es un hervidero de razas. De este crisol- continuó sin detenerse,- ha de salir la verdad civilizadora. Todavía no estamos en ella. El atavismo impera. Poca gente se baña en este país y para ser grandes, es preciso empezar por ser aseados. Intus et extra. iLa mugre suele contaminar la integridad psícológica de los pueblos! (vol. II, p. 14)

He presents the case in favour of Immigration by listing the various nationalities living in Argentina and describing their characteristics, and their role in the country's history. His opinions are valuable not only for their documentary content, but also as an indication of the stereotyped image projected with regards to each group. He says about the Italians that they constitute the majority of the immigrants who came to Argentina and gives an over-idealized picture of them as the main element in the transformation of both the country and the city. ${ }^{7}$ Because of their labour, the land has become an agricultural Paradise in which the smell of the new crops mingles symbolically with the smell of their homely cooking:

... en el ambiente quieto con olor a gramilla y alfalfares, sobre el humus negro y húmedo de polen picoteado por las gaviotas en bandadas se difunde de la cocina una fragancia de albahacas y quesos de Parma. Es el hogar italiano. La sopa de legumbres hierve en las ollas de barro y es saludada por los cantos de los trabajadores que vuelven despacio, la azada al hombro. (vol. II, p. 26)

In the city, they are the mainstay of a flourishing building industry which has completely altered the look of Buenos Aires. Describing the Italian city workers, the author forgets all his previous accusations regarding the lack of hygiene which exists in big cities and the dangers of disease, and stresses the usefulness of their contribution to the expansion of the capital. He attaches a particular leitmotiv to them: 'son los constructores de las casas de dos piezas y cerco de rojo ladrillo', which is repeated many times and stereotypes them into the passive role of a contented labour class. And, with words which are reminiscent of Saldías's insistence upon the full integration of immigration into the national ife, they are praised for their action in civil wars:

Vengan tus hijos. El corazón de la tierra argentina tiene criptas enormes para cobijarlos. Son honestos. Trabajan. Son los constructores de las casas de dos piezas y cerco de rojo ladrillo. Han esbozado a Buenos Aires. Son los dueños de casi todas las pequeñas industrias y el ahorro es en ellos una índole. No entran en la vida pública sino para acompañarnos a sufrir. Han sido conmilitones en las guerras nacionales y apasionados de los ídolos populares, se dejaron arrastrar en las discordias fratricidas. A pesar de eso el día de ellos es útil a la patria. (vol. II, p. 27) 
Unlike other authors, who, even when favouring Immigration, wished to circumscribe its activities to the development of the land or of commerce and industry, Sicardi notes with approval the presence of second generation immigrants in the universities, forecasting that these children will be the new professional classes of tomorrow. In describing the Italian community Sicardi reflects their main areas of involvement in the contemporary scene, but his unrealistic portrayal glosses over not only the problems that the immigrants had to face, but also the resentment and threat that their presence and that of others was causing among the local population.

The portrayal of Italian immigrants sounds in the nature of a proposal to the reader to accept the commodity offered for it will benefit him and his country.

The British have their own spokesman in a character created expressly for this purpose. In an exchange with Paloche, he speaks of his people as peaceful and homeloving, carrying Britain in their hearts wherever they go. He ascribes what he considers the unquestioned superiority of the British to a healthy and practical attitude to life, free from the constant preoccupation of society's approval. The portrayal of the British way of life is crudely caricaturized, with its description of pipe-smoking men dressed in dowdy but comfortable clothes, exercising their body in healthy sport, united with their families in devotional prayers and formal dinners (vol. II, p. 35). The Englishman's overt confession of materialistic aims, declaring that riches are virtuous and morally desirable, and praising such mundane things as financial acumen and a pragmatic attitude to life, finds much approval in the eyes of Don Manuel Paloche. The echo of Alberdi can be heard in the following words:

Conquistan para enriquecerse, porque ese es un medio de ecuanimidad moral y de felicidad humana y una resultante de virtud y para civilizar, porque éste es pueblo que ama a Dios, respeta al hogar y busca en definitiva, digan lo que quieran, que sea sagrada la libertad del hombre. Por esto ha resultado un pueblo superior. (vol. II, p. 36)

Earlier on in the novel Paloche had expressed regret at the action of the porteños in 1807, when they repelled the British invaders:

Después de la derrota han debido incorporarlos. Habría hoy mucha gente rubia de verdad. Tal vez fuéramos muchos millones más, porque ésta es estirpe que procrea abundante y no cree en el heroísmo que no trabaja y se destruye en las guerras civiles. Y después es un pueblo que hace muchos años que sabe sumar y restar. Conoce el ahorro. El error fue devolverlos a la Europa. 
Menos mal, porque de todas maneras la conquista se produjo y por el lado de los pies y del bolsillo. Nadie da un paso en este país sino en inglés. Nos han arrebatado la facultad animal de movernos. Toda la viabilidad es de ellos. (vol. II, p. 14)

It is typical of Paloche/Sicardi to end with an ambiguous statement concerning the desirability of the railways, saying that on the one hand they bring prosperity and on the other laziness. (The pun on the word viable is an example of Sicardi's humour and wit.)

The Northern race are generally depicted in the literature under review with thick brush strokes and little subtlety, and the portrayal of the Germans in Libro extraño is no exception to this. They are dismissed with the usual stereotyped attributes as serious, erudite, humourless, rigid and unimaginative. They are erroneously said to be completely apolitical since the Club Alemán Vorwarts founded in 1882 was the first important socialist organization in Argentina. ${ }^{8}$ Yet it is described as follows:

Era un club alemán. Estaban sentados alrededor de pequeñas mesas. Tomaban cerveza en copas largas y cónicas y eran rubios, de tez sonrosada y fresca, casi infantil y robustos. La entrada de los personajes sucios de lodo y agitados no los ha conmovido. Siguen tomando cerveza y conversando. No hablan de la revolución. Ni se ocupan. Lo que se oye en todas partes es la palabra oro. Parce una bolsa de comercio. (vol. II, p. 83)

The Germans are acknowledged to be less domineering than the British and to mix better with the criollos, to the extent that their children are quite integrated into Argentine life, yet they seem to lack the special prestige of the British.

Next on the list are the French. It is interesting to note that they are discussed chiefly in cultural rather than in human terms, because they epitomize for Paloche European civilization. He acknowledges their influence, pervading all the higher echelons of Argentine life, to be found in habits of food, language and manners as well as in the layout and architecture of the wealthier districts of Buenos Aires, and says that their books have revolutionized thought in Argentina in all fields, scientific and literary.

In Libro extraño, praise of anything European is usually accompanied by an expression of regret for what is being eroded from criollo culture, and in this instance, it is that the lighter, more jovial style of writing due to French influence is keeping local subjects out of fashion: 'los escritores desdeñan el tema de la tierra y no conocen la observación. Hasta los argumentos de 
sus libros suelen ser europeos' (vol. II, p. 44). There is yet a further negative aspect ascribed to French influence, and that is that it is seen as contrary to that of traditional criollo Catholicism. The problem is complex, for while the most advanced ideas of French Positive thought were readily acceptable at the abstract level, the same open-mindedness was not found at the personal level of the home, and in many the reading of Zola was proscribed. This was due to a superficial reading of the French Naturalist, and a prejudice based on the subject matter of his work which totally disregarded the intention behind it. The following extract, though light in tone, reflects a deeper preocccupation with French as an unsettling and morally subversive influence:

Es preciso amar a Zola, porque ha destruído mucha gazmoñería, se ha metido en las casas y vive escondido en los roperos perfumados entre los rasos y el encaje de Inglaterra. iAh bribón! Se ha revuelto en el lodo, pero es el pintor más profundo de lo sensual. Aquí como en Francia cada uno ha tenido veinte años, una mesa de luz y una vela de estearina para prenderla a las dos de la mañana, cuando los padres duermen. Es la hora de leerlo, entre las sábanas, acariciados por el calor afrodisíaco. Siempre hay tiempo al día siguiente para rezar el rosario, devotamente arrodillados bajo las bóvedas doradas de la catedral y arrepentirse de leer a Francia que ha inventado en este país al demonio, al mundo y a la carne. (vol. II, p. 44)

Although the influence of France took place essentially on a cultural level, French immigrants are mentioned as having made a mark on Argentine life too, particularly in wholesale commerce. They are said to integrate well.

The Basques are the author's favourite immigrants and he speaks of them as a race and nation apart, not including them either in his comments on the French or the Spanish. He does, however, make a nominal distinction between the French and Spanish Basques. Paloche is full of praising admiration for them because, he says, they are not poverty-stricken when they arrive; they are cheerful, healthy, sports-loving, generous, strong, stroical and hardworking. They combine, in short, the best of the criollo values of vigour and generosity, with the qualities demanded of all immigrants, i.e. a willingness and aptitude for work, and in addition to this, their history of a strong, healthy, outdoor existence appeals to the prophylactic theories so valued by the doctor in Sicardi. They are the chosen seed from which the proposed model for a New Argentine will stem:

Los vascos son los inmigrantes más vigorosos que llegan al país. Estos no traen ni síflis ni tuberculosis. Llegan saturados del aire vivo de la montaña y tienen 
sangre bermeja, tan pura y cristalina como el agua de sus torrentes. Son musculosos y gigantescos, de torso levantado y brazo hercúleo, los mismos de antes cuando despedazaban la roca para hundir cráneos de enemigos con sus fragmentos. Son honestos. Así defendieron sus abruptos desfiladeros y así conservaron incontaminados su hogar, su religión y su lengua. (vol. II, p. 46)

The Spanish fare less well because of accusations of haughtiness and arrogance. There are vestiges of resentment at their old, hated, colonial role, yet as that era recedes into the past, and the much acclaimed material benefits of Western Europe begin to threaten the hegemony of the existing population, so there is a trend in literature to idealize the colonial era and remember it as a past Golden Age. (Examples of this were found in Martel's La Bolsa.) Sicardi's enthusiasm allows his idealization to take an absurd flight into fantasy, when he asserts the aristocratic origins of the first settlers:

La buena sociedad de antes, era grave y ceremoniosa. Cada uno era un grande de España. Los antepasados habían sido por lo menos gentileshombres a corte y muchos a pesar de las nuevas ideas republicans, conservaban sus entusiasmos y sus sinceros fanatismos por el símbolo de la realeza. (vol. II, pp. 42-3)

The truth is that Spanish immigration to the River Plate was largely commercially oriented and did not consist of grandees or other noblemen who were more likely to be attracted to the powerful viceroyalties of Mexico and Perú. To the River Plate came merchants in search of contraband and the disinherited peasants from the poorer sections of ' ndalucía and Extremadura. When the Crown eventually sought to legal se the increasing trade that had developed in the area, and established a Viceregal Court in Buenos Aires in 1776, this brought lawyers, bureaucrats, priests, and military officers as well as more artisans, soldiers, labourers and slaves.? As individual immigrants, the Spanish are usually stereotyped as strong and hardworking, but those from Andalucía, as gay spendthrifts. Their life as shopkeepers, whose role in provincial outposts is highly valued by Paloche, is described as follows:

La honradez gallega ${ }^{10}$ es como veinte honradeces juntas y las historias de virtud y de labor que se han desarrollado aquíson tantas, que puede decirse que ellos han contribuído mucho a la evolución. Es siempre la misma. Empiezan por barrer la tienda a los diez años, limpian las lámparas de kerosene y concluyen muchos a los cuarenta por ser dueños de registros y de estancias. Todo ese tiempo ha sido una larga serie de abnegaciones, la entrega de la juventud entera al deber y al trabajo. Hay siempre un mostrador, ese liso y barnizado paralelepípedo. Es la barrera que la pobreza ha puesto entre ellos y el mundo. (vol. II, p. 55) 
Paloche's sentimentalized language changes to a more sober tone, and in his subsequent description of their progress in Argentina, he follows the formative stages encountered in Teodoro Foronda:

En cada tienda hay españoles y muchos de esos hondos socavones llamados almacenes por mayor y registros, les pertenecen. Han llegado hasta allí a través de toda una odisea, después de haber estado años enteros detrás del mostrador y de haber demostrado que lo tenían bueno. Tener buen mostrador, constituye un bachillerato. Se necesitan muchas condiciones. Ser amables con el cliente, saber sus mañas, si es generaro o avaro, cuáles son sus vanidades y su lado flaco y sobre todo, hacerle comprar aunque no quiera y marearlo siempre con la palabra y con el gesto hasta que se convence y afloja la bolsa. A fuerza de demostrar esto a la perfección, los patrones encuentran que deben ayudarlos. Entonces le dan dinero para que ponga un negocio. Se hacen dueños a su vez, siguen la misma vida de antes y empiezan su bienestar en medio del prodigio de las riquezas de la nación. Aquí trabaja esta raza. (vol. II, pp. 55-6)

As a synthesis of all the portrayals of the immigrants, certain points emerge: all the different nationalities are presented in connection with work and prosperity; they are all depicted as healthy and vigorous individuals; all (except some of the Spanish) are said to be apolitical, and this is stated in approving terms, and all (except the British) are said either to assimilate well and become fully integrated members of Argentine society or, as with the Spanish and the Basque, Argentine society is traced back to them. The presentation of the immigrants is purposely attractive: they are depicted as a useful and desirable asset to the country.

It has already been noted that Sicardi adopted Sarmiento's formulation of Civilization and Barbarism in his own view of Argentine history. But the stance from which both writers approach the question differs, since Sarmiento's aim in Facundo was to denigrate barbarism by exposing its ills, and Sicardi's is to advocate civilization by praising its achievements. The ambiguity of Facundo was examined in the opening chapter of this thesis, and it is interesting to observe, in this last chapter, an even wider manifestation of the same phenomenon. For while it was held that Sarmiento's ambiguity rested principally on a tension between the ideological and the aesthetic aspects of Facundo, and the same tension was observed in Libro extraño, Sicardi lacks conviction and constancy even with regard to the ideas that he appears to be advocating. This is most in evidence in his position towards Immigration. In general terms, he favours it and welcomes the arrival of the immigrants as a civilizing influence which will cause the country to advance from its present stage of barbarism. He synthesizes the process by means of the following metaphor: 'el buey empezó a vencer al león'. The lion is wild, fierce and unproductive, but at 
the same time he is the noblest of animals, and the undisputed king of the jungle. The ox is the animal which symbolizes agricultural fertility and animal husbandry but at the same time stands for the passive, unimaginative beast of burden. Thus, the connotations of both buey and león are ambiguous, and reflect the ambiguity of Sicardi's position vis-à-vis both the immigrants and the criollos. He describes the transition from barbarism to civilization as follows:

El alma de la vieja raza vivía embriagada del culto al heroísmo. No se podía ser otra cosa que valientes. El país era del caudillo más vagabundo y pendenciero, del mejor domador y del más diestro y más temerario en la lucha cuerpo a cuerpo. (vol. II, p. 20)

Sicardi repeats Sarmiento's deterministic idea of explaining the civil wars as the result of prevailing circumstances:

Y como no había más religión que el peligro ni más culto que el valor personal, eran patriarcas los más heroicos y los más homicidas. Así han resultado algunas figuras, rodeadas de lúgubre grandeza. El criterio moderno habla de tiranías y de crueldades sin fin, la justicia histórica tal vez encuentre que no fueron sino personalidades sintéticas de un medio salvaje. (vol. II, p. 22)

But when he concludes that 'el gran error de toda la evolución fue haberse operado por el heroísmo' (vol. II, p. 22), altering the emphasis from barbarism to heroism, he begins to idealize the very system that he has set out to condemn. He concludes as follows:

El heroísmo empezó a ser substituído por el trabajo y la natural generosidad de los nativos, que había producido épocas de riquezas ficticias y de derroches sin cuento y a ratos dolorosas pobrezas, cedió el campo a la labor ordenada y constante y por ende más provechosa. (vol. II, p. 22)

The extract serves to illustrate the utopian gloss with which the author misrepresents complex historical facts. Far from being generously and cheaply handed over by the natives, such land as was not already in possession of the élite was hurriedly bought up by it, its value soaring with increased productivity and improved means of communication. Except for certain areas in the Provinces of Santa Fe and Entre Ríos, the immigrants found it impossible to buy any land, and had to content themselves with an exploitative system of tenant farming. ${ }^{11}$ This in fact was one of the causes of dissatisfaction which made many of the immigrants leave the land and opt for life in the cities instead. The rather simplistic and overidealized picture of the élite described as bidalgos, and of the immigrants 
united as one big family, ignores not only the difficulties of acclimatization on the part of the ones and problems of resentment on the part of the others, but also fails to acknowledge the closing of the ranks of the élite which followed as a consequence of Immigration. ${ }^{12}$

For Sicardi, Immigration was synonymous with change, which according to the optimism of Positivist thought was synonymous with progress. And, on the whole, the author presents the changes wrought by Immigration in that light, but he usually allows some qualifying remark to undermine the effect of his original statement. After having paid tribute to the contribution of Immigration to the development of the pampa, Sicardi implies that there is something mean about exploiting and and parcelling it up with barbed wire fencing. ${ }^{13}$ The final impression is a feeling of regret for the free and noble days which have gone (vol. II, p. 24). The transformation of Buenos Aires from 'la gran aldea' of the pre-Immigration days to the largest and most important city of the Sub-continent, is described with similar ambiguity.

A backward glance to the pre-Immigration days conjures up a nostalgic picture of feudal starkness and edenic plenty: ' ... se ha perdido la monástica seriedad de los antiguos edificios con sus grandes patios de baldosas y ladrillos llenos de verdín. Han tronchado las higueras y los parrales de gruesa cepa' (vol. II, p. 5). The new city is described by passages which, within a few lines, contradict each other by their tone and their implications.

The immigrants are said to have brought life and the city vibrates with their gaiety:'por todas partes hay un ímpetu de vida ferviente y alegre' (vol. II, p. 5). But as the vibrations become more strident, the image is one of chaos verging on farce:

Por todas partes cruzan alambres. Buenos Aires es una jaula. La electricidad lleva y trae la palabra y el pensamiento humano; los tranvías, los carros y coches se atropellan en sus calles, chocan y suenan. (vol. II, p. 6)

This is followed by a peaceful image of a diligent and thriving community: 'un enjambre de trabajadores usa cal y ladrillo hace tiempo y hay en las pequeñas casas de dos piezas una muchedumbre laboriosa que trabaja y ahorra' (vol. II, p. 6). But Sicardi clearly resents the effect of the increases in population, and while the details of what he records reflect the overcrowding and lack of sanitation of the growing city, there is no objective attempt on his part to inquire what it felt like to live under those conditions:

Hay mucha hediondez. Por las puertas se escapa esa náusea; olores a grasa rancia, a cuero podrido, a fango viejo, dejos malsanos de cocinas sucias, 
oleadas de sótanos cerrados, emanaciones de legumbres marchitas y hacinadas; soplos gangrenosos y aleteos de cuando en cuando de purulencias escondidas; una atmósfera sucia y densa de cortar con cuchillo, cuyos átomos han salido de las ropavejerías y de los bodegones y están llenos de todas las acritudes de los mercados, del olor a bosta y de las picazones del amoníaco de los orines que saturan los pavimentos. En las noches de verano se levanta silencioso del suelo un vaho, que es como la síntesis de todas las contaminaciones, que sabe a matete y a porquería, cuajado de las respiraciones de las bestias que han pisoteado la calle y del olor de los cuerpos sucios de sudor y de tierra.

La gente no se apercibe. (vol. II, p. 7; my italics)

Sicardi is an acute observer of the miseries and social injustices of his time, but he fails to draw any conclusions from his own observations, or allow them to interfere with his ideas, which must therefore be judged as somewhat ill-conceived and superficial. In the light of the foregoing description, the author's final reflection on Buenos Aires, full of cheerful optimism, seems incomprehensible: 'su sangre es roja y sana- piensa don Manuel. - Su musculatura es robusta y dominadora. Tiene el corazón alegre y el estómago lleno y el alma buena. Es la ciudad feliz y rica' (vol. II, p. 11).

As with the changing face of the pampas, so the changes in the city are viewed with ambiguity. Against the perspective of an idealized past, the growth of Buenos Aires is offered as a sign of positive advancement, but whose innovations seem at times to be regretted and feared, judging by the exaggerated distaste in which some of them are described.

One of the most lasting changes that massive Immigration brought with it is that which affected the ethnic composition of the population. Sicardi foresaw the problems of an identity crisis and offers in Libro extraño a proposal for the new Argentine, in a mixed breed based upon the intermarriage of criollos and Europeans. He develops his idea by making an extensive study of what he himself terms the old population, formed by a mixture of Indians and criollos. There are two Indian characters in the work, widely different in their presentation. The first is the hero of a legend telling the story of the Spanish Conquest. His name is Pincencurá and he evokes the image of the noble savage: 'Yo soy Pincencurá, rey moribundo de las Pampas, alma heroica e indomitable de todas las resistencias' (vol. I, p. 312). Pincencurá berates the Spaniards for destroying their civilization, and enriching themselves with their labour, instead of having made fusion of both races which would have incorporated the best of each. It is interesting to note the attributes that he values: the Spanish for their iron heart, presumably meaning their valour, and the Indians for the purity of their language. He says: 
Han podido educar: darnos el corazón de hierro de vuestra raza, y nosotros enriquecernos la sangre con la pureza de los vientos de la montaña, y la inteligencia de los virginales cánticos de nuestro idioma incontaminado. Han preferido matar; eso era más fácil ... Así sea. (vol. I, pp. 312-13)

There is a dramatic warning in Pincencurá's speech that while the conquerors are becoming rich with the spoils of the country, and relax their vigilance ('se saturan de oro y de molicie', vol. I, p. 313), foreign hordes are preparing to conquer them in turn. The allegory of immigration can be easily detected.

The other Indian mentioned can be said to symbolize the changed image of the Indian in European culture, for the descendant of the noble Pincencurá occupies now the lowest rung on the Evolutionist ladder:

Aquello no era un rostro, sino una máscara con su frente chata y hundida, las narices dilatadas y amplias, gruesos los labios, la piel cobriza y agujereada por la viruela, cuatro cerdas gruesas en la barba y una que otra chuza de bigote en el labio superior. Era un indio. Paloche reconoció a uno de sus antepasados ... (vol. II, p. 11)

Sicardi's views on the mestizos and the criollos can be compared, for ambivalence and inconsistency, with his portrayal of immigration, only in this instance the process seems reversed. He cries out against them for their barbarism, their corruptness, their laziness, their lack of discipline and of hygiene, yet ends up by praising them for their nobility and disinterested generosity.

Sicardi's theoretical exposition of criollo values is summarized in Don Manuel Paloche, and is placed in the context of his views on Immigration. His argument develops in several stages. The first deals with the question of political corruption, and Sicardi expresses disappointment at the fact that the misdemeanours of the old elitist government should be perpetuated in the new popular government of the day. This seems a clear though unspecified allusion to the popular revolt which led to the fall of the fraudulent government of Juárez Celman in 1890, and to the emergence, in 1891, of the Radical Party pledged to political reform. Sicardi writes:

... pero la forma en que se desenvuelve la política es siempre la misma y comprende entonces que la podredumbre que contamina las alturas, ha descendido al valle y que un nuevo gobierno indisciplinado, violento y callejero se ha colocado enfrente de la vieja y caduca larva que vive por derecho en las casas rosadas y en los congresos. (vol. II, pp. 17-18) 
It is typical of the author to say in one and the same sentence that the old government was rotten, moribund, yet the rightful occupier of the seat of government. ${ }^{14} \mathrm{He}$ then goes on to say that the spirit of revolution is endemic to the criollos, whom in this context he terms as aborigenes ${ }^{15}$ and contrasts with las razas, the immigrants, who are docile and peace-loving: 'vió que la revolución era una enfermedad crónica y hereditaria y empezó a creer que aquello resultaba una índole. La llamaba idiosincrasia aborigen' (vol. II, pp. 19-20). This does not preclude Sicardi from expressing totally opposite views elsewhere, decrying the reign of brute force which prevailed in an era which is remembered sometimes as anarchical and violent, and sometimes as feudal and orderly.

As Sicardi moves forward in his argument in favour of the influence of disciplined and productive immigration, so he glances further back in time and constructs a mythified criollo ancestry expressed in terms of medieval knighthood. One of the traditional qualities of the nobility is a lofty spirituality unblemished by any materialistic aim, and Sicardi idealized the old patrician society in these terms. Using archaic metaphors, he opposes the old nobility, la nobleza de antaño, to the newly arrived nobleza de ocaño, and expresses admiration for the austerity of the ones as against the brashness of the others.

Y después ... la retahila de gordos muchachos de color indefinido, hablando una jerga imposible, mientras desaparecía la llanura fragmentada por los alambrados. Todo ese hondo misterio, toda la siniestra leyenda de la estepa sin término, reveló a la locomotora en marcha la robustez prodigiosa de su entraña y los lúgubres dioses, borrachos en el denuedo salvaje, sicarios y salteadores, volando semi-desnudos en la carrera frenética y violando los silencios de las soledades con el berrido estridente de la horda que cautiva y asola, los lúgubres dioses fueron repelidos hasta las gargantas de la cordillera y sus esqueletos tendidos sobre el inmane osario de la montaña. En esta conquista de la pampa concluyeron los nativos su ciclo heroico. Entregaron el país al trabajo. (vol. II, p. 24)

There is an explanantion for this double vision of the 'old population'. The Argentine intellectual élite was not firmly rooted in its own culture, being divided in its allegiance between a Spanish, a mestizo, and a cosmopolitan heritage. It lacked therefore the support of a firm anchorage point with which to counteract the effect of an immigration on such a scale that in certain areas it was beginning to outnumber the local population. But the problem posed by Immigration was not simply one of numbers. It was also related to ethnic considerations which, as will be remembered, played an important part in the thought of the early advocates such as 
Sarmiento and Alberdi. They had predicted an immigration which would be not only a profitable and docile labour force but also a positive influence in racial and cultural terms. The reality fell short of these prognostications, since a large proportion of immigrants cam from heavily depressed and backward areas and were culturally as underdeveloped as the local mestizos. On the other hand, others had been ejected from their country as instigators of political strife and thus brought with them advanced ideas of subversion which alarmed the writers of the intellectual élite. This is the reason why Sicardi projects the 'old population' in an increasingly favourable light, and why he seems uncertain in his attitude towards the immigrants.

There is no ambivalence, however, in Sicardi's attitude towards the New Argentine. Here, theory and fiction coincide and are imbued with assured optimism about a new race which synthesizes the highest qualities of all its component peoples. Sicardi names this new race 'el hombre argentino' and traces its development to a process of selection of the fittest. The welcome change from a dark-skinned population to a white-skinned, fairhaired new breed, is explained in strict evolutionary terms as an example of the perfectability of the human race. His argument runs as follows:

La creación de esta sorda lucha de razas es el hombre argentino. Todos los tipos de la tierra contribuyen a formar su tipo físico. La capital produce lo más perfecto. Hace rato que se está allí involucrando y germinando el polen universal. El hombre argentino es más bien alto que bajo, superior en su talla al español y al napolitano, inferior al alemán. No es gigantesco como el vasco, ni flaco como el andaluz y el calabrés. Hablamos de los que se observan aquí. Antes predominaba el color moreno con su palidez sana y marmórea, el ojo y el cabello negro. Ese era un argentino, pero de poca mezcla; más tarde sigue la transformación y aparece el blanco, color cuajado, de pelo rubio y ojos azules. Los hombres del Norte de Europa han engendrado este tipo. De chicos parecen albinos, de grandes les queda color de oro el sistema piloso. Hay ejemplos intermediarios y son los más de tez blanca y pelo castaño. (vol. II, p. 61)

Sicardi then goes on to talk of the disappearance of negroes and mulattoes which occurred in Argentina in the nineteenth century and has remained one of the unsolved mysteries occupying social historians even today. ${ }^{16}$ $\mathrm{He}$, however, assuming the authority of the scientist, offers a ready explanation for this phenomenon: he alleges that being physiologically inferior, the dark races are too weakened to withstand the ravages of tuberculosis. Yet he forgets that elsewhere his own creation, Elbio Errécar, asserts with greater conviction that the causes of death from tuberculosis 
are racial and not socio-economic (vol. II, p. 523). A study of the validity of Sicardi's theories in scientific terms surpasses the limits of this thesis; what is of interest here is an analysis of the attributes with which he endows the new race.

The qualities most valued are physical and relate to the immigrants' invigorating health and strength: 'en resumen, el hombre argentino de hoy es más fuerte que el antiguo, tiene cuerpo más elevado y mejor color. Muere menos. Es más activo. No ama la siesta, porque el día le es corto' (vol. II, p. 62). Sicardi goes so far as to say that those parts of the country which have not received the advantages of immigration find themselves in a backward position, prone to extinction:

Por eso el hombre argentino de allí es diferente; no recibe savia de afuera, necesaria para la perpetuidad de las razas; no busca el matrimonio fuera de su cortijo, ni sale de él. Encerrado en el pequeño círculo, el matrimonio de consanguíneos a través de tantas generaciones, ha producido un tipo débil, de mal color y caduco, y la locomotora que ha empezado la era nueva y vivificadora, saluda en su violenta carrera a los morituros. (vol. II, p. 63)

The author has thus transposed a predominantly political and economic situation, i.e. the increasing hegemony of the Litoral over the rest of the country, on to a racial plane. This attitude is consistent with that observed in all the literature under review. Sicardi, betraying a nationalist and imperialist dream, proclaims a missionary role for the New Argentine, to be fulfilled throughout the Hispanic Continent:

El hombre argentino sabe que en este continente es hegemónico. Comprende que de su nación se desprende una fuerza benéfica utilizada por los demás pueblos y esta idea de la grandeza futura pasa en su historia a través de todas las épocas, a través de sus victorias y en la derrota, entre los horrores cruentos de la anarquía y en sus resurrecciones. Es su oriflama y su coraza. Es el poema vibrante de estrofa sonora y heroica que le indica el sendero abrupto, en cuyo fondo está la acrópolis de granito, custodia de la integridad de América, erizada de cañones y amenazadora. (vol. II, p. 62)

The New Argentine, however, is not merely an abstract theoretical proposition but is personified by the figure of Elbio Errécar. The idealized characterization of Elbio has already been noted; his role in the novel is reduced to two functions, both of purely ideological importance. One is his marriage to Angélica Mendez, but this incident is so devoid of human interest for the author, that it is dealt with with the utmost brevity (in marked contrast to the long drawn-out character of the work as a whole):

Elbio y Angélica se amaron para casarse. Era una fuerte pasión. Casi ecuánime. Ellos hicieron la fiesta, en el largo idilio desde niños, de manera que las bodas 
no fueron un acontecimiento. Este corolario se compuso de una marcha nupcial, una corona de azahares, un largo traje de raso blanco y el tul de las novias rozando, hacia el altar mayor, las alfombras del templo, entre el esplendor de mil cirios, bajo las pinturas murales que adornaban las naves. Y como nunca habían dudado que eso iba a suceder, sonriendo se cambiaron el anillo, símbolo de la eterna unión, delante del sacerdote. Ellos sabían, hacía tiempo, que ese juramento concluiría cuando los dos muriesen ... (vol. II, p. 614)

Elbio's other role is as political leader of the masses, and it is the content of his ideology which is of interest, rather than his artificial and idealized rise to a position of leadership.

Libro extraño's last book, Hacia la justicia, is concerned with the social and political unrest which was besetting the country at Sicardi's time of writing (1894-1902). It refers to strikes and demonstrations of dissastisfaction brought about by the decrease in wages in certain occupations, rising costs, and crowded and disease-ridden living conditions. These facts are substantiated: the historian J. Scobie records that the depression of the early $1890 \mathrm{~s}$ cut wages by more than half, adding that because of fluctuations in the cost of living, real wages fell drastically between $1890-93 .{ }^{17}$ Overabundance of labour during these years meant that unskilled workers had to contend with deteriorating conditions, but, largely at the instigation of politically active Spanish and Italian immigrants, these years also saw the beginning of organized unrest. In J. Scobie's words:

In the 1890 s in particular, socialist and anarchist agitation, fueled by experienced and dedicated organizers from Spain and Italy, promised to mobilize labour into an aggressive and effective force. The sharp reaction of Argentina's ruling merchant-landowner élite at the beginning of the twentieth century, combined with the turning of the economic cycle - an overabundance of labour from 1890 to 1903, followed by a period of rising wages and opportunities from 1905 to 1912 - handicapped the labour movement. What emerged were trade union organizations that affected skilled workmen. ${ }^{18}$

Sicardi depicts the above situation, but in a highly distorted manner. He presents the agitators as the followers of the anarchist Germán Valverde, a violent, vindictive mass whose identity is not specified but is strongly suggested to be criollo. The adverse conditions under which they exist are described with expressionistic detail:

Los obreros, los pocos que tienen trabajo, caminan bajo la llovizna fastidiosa con las botas llenas de barro, con el único traje empapado sobre las carnes que tiritan. Caminan sin paraguas deslizándose a lo largo de las paredes cual delincuentes que quisieran ocultarse, resbalan por las veredas, hacen saltar el 
lodo de los charcos y llevan el corazón blasfemo como moléculas desheredadas y malditas. Llegan al taller donde las máquinas chirrían bajo la luz amarilla del gas que ilumina las estrechas zahurdas contaminadas por las hediondeces de rancias grasas, tufos de carbón y podredumbres de venenos de cuerpos sucios y sudorosos en los impíos hacinamientos. En esas casamatas trabajan los pobres y piensan que en la casucha miserable donde viven los hijos, están los techos rotos y se llueve como afuera, y del piso de ladrillo mana agua negra del pantano que hay en el subsuelo. iGipen no más, muéranse tuberculosos, bestias de carga, gusanos anónimos de todas las naciones! (vol. II, p. 409)

Germán, son of the criollo cynic Valverde, rouses the workers with an inflammatory speech:

-¿Qué hacemos?- preguntó éste con violencia. -¿Y la huelga? ¿Qué esperan? Que les dupliquen el salario. Que el obrero sea socio del patrón. Que muestren los libros de sus escritorios, esos tramposos. iQué les hagan casas aseadas! ¿O el sol es de ellos no más y ustedes tienen que vivir entre el estiércol de los conventillos? Hagan la huelga y no se detengan en eso. iParece que ustedes no supieran que en los almacenes hay aguardiente y petróleo! ¿Hasta cuándo? iPor Cristo! No es solamente con los pintores. A ustedes les digo, que son tipógrafos y se lo pasan el día entero componiendo imbecilidades. Tienen vómitos ustedes ieh? Se mueren de diarrea. Echan los bofes a pedazos, como los tísicos. La sangre se les envenena. El hospital les espera si siguen trabajando. Allá se meten a aullar como perros apaleados, con esos manchones color pizarra que tienen en la cara. Sigan no más. iNo van a durar mucho tiempo! No hagan la revolución social. Con ganar tres pesos y medio por día ¿van a resolver el porvenir? (vol. II, p. 487)

In this speech, Sicardi mentions painters amongst other groups of dissatisfied workers. It is an example worth quoting that according to statistical records, $79.8 \%$ of painters active in Argentina were foreign born. ${ }^{19}$ Yet this factor is neither mentioned nor suggested.

The crowd's reaction is described as follows:

Rodeaban al anarquista sin moverse. No tenían hambre. Por la mañana habían bebido en los almacenes los malos alcoholes que queman el estómago. Eso les bastaba para seguir viviendo; pero había muchas caras pálidas y muchos organismos flacos, bañados de caña y ajenjo. Con el cuerpo enfermo, iba rodando el alma enferma de esos trabajadores. Los seducía la diatriba violenta y la aventura peligrosa. Se olvidaban de la labor continuada y honesta, la única generosa y fecunda. (vol. II, p. 488)

In Sicardi's representation of events this aggressive crowd is contrasted with another, industrious, healthy, gay and contented, and with obvious indications that it was composed of immigrants:

Una infinita alegría de vida sana agitaba la calle, y por todas partes se erguían casas y más casas, talleres y más talleres, y así, hasta muy lejos, los trabajadores 
vigorosos seguían escribiendo el libro del ahorro con que se ha edificado la ciudad bulliciosa. ... Venían a esta tierra los inmigrantes en busca de las nobles eucaristías del trabajo con recompensa. Poco tiempo después construían las casas pequeñas y esos formidables musculares entraban allí con la compañera del brazo para transformarlas en santuarios. ... La familia numerosa y robusta coronaba la vejez del obrero, del albañil de la gran ciudad, el cíclope que ha construído sus bloques interminables. Otros ganaron los campos para cultivarlos. Rompieron el césped y rastrillaron su polvo negro y fecundo. Crearon las colonias y construyeron los ferrocarriles para unir a los ciudadanos de la República. Eran fisiológicos de cuerpo y alma, y la obra resultó un prodigio. Son leguas de trigo y leguas de viñedos; es una multiplicación lujuriosa de haciendas. La pampa sola y salvaje se entregó a todas las razas para que la poblaran de aldeas y de virtudes. Eso sucedió porque los jornales eran siempre suficientes y no se discutían. Se bebía menos y se trabajaba más. (vol. II, pp. 488-9)

The masses, in fact, appeared divided into three main factions; the first two being the anarchist followers of Germán, and the equally aggressive followers of Ricardo Mendez. The latter Catholic group is probably representative of the nationalist and conservative Liga Patriótica Nacio$\mathrm{nal}^{20}$ The author's disapproval of both is evident in the following passage:

Las dos psicologías se prepararon a despedazarse. De un lado los cruzados, dispuestos a morir y a matar por la religión; del otrolos vengadores, dispuestos a morir y a matar por los sacrificados de todos los tiempos. El apostolado de las dos sectas había sido rudo y se habían encontrado muchas veces en los mismos conventillos, en pos de prosélitos, y mientras aquéllos prometían la felicidad futura, éstos hablaban del bienestar presente. ... Los primeros educaban la grey hacia atrás, hacia la revelación y el dogma: escribían la poesía de las catacumbas y la gloria de los circos enrojecidos de sangre cristiana; los otros apuraban el porvenir a través de la utopía de la nivelación humana, para que todos tuvieran el mismo dinero, el mismo saber, los mismos derechos; desconociendo aquéllos los beneficios de la libertad intelectual y éstos la necesidad de la selección paulatina y la superioridad de los selectos. (vol. II, p. 559)

This division is significant in that, contrary to objective facts, it stands the immigrants apart from the agitators and projects them in a peaceful and positive light. They form largely the third group, the followers of the upright, progressive Elbio Errécar. He is a well-intentioned idealist, an optimist who believes in the fulfilment of his cause on the grounds of its inherent justice. His ideas are oriented towards a peaceful policy in the direction of Socialism. He says that each occupation ought to have regulations according to the demands that it makes upon workers' health. Furthermore, he acknowledges that poor living and working conditions 
lead to alcoholism and even to early death; he generously wishes for two days off per week for certain workers, ${ }^{21}$ shorter hours, particularly for women, and better wages (see vol. II, pp. 523-5). Elbio's advice on how the workers are to obtain these rights is not consistent with the accusations of powerful repression and exploitation made earlier. With a simplistic and utopian faith in the work ethic and in evolutionary progress which does not delve into economic or political detals, he voices his loftily conceived capitalist ideal. It is succinctly summarized in the following words:

Luchen; pero no sean anarquistas. No hagan la huelga. La mejor manera de de demoler a los patrones, es hacerse uno mismo patrón.

Eso no se consigue con la haraganería, sino con el trabajo constante y con el ahorro. ¿Acaso es imposible llegar? Se precisa no ser observadores para afirmar semejante error, y no haber vivido aquí. Y después la huelga resulta un plagio vulgar. Nunca podrá ser sino un artificio, nunca una emanación natural de esta tierra, donde hay trabajo para todos. Un plagio es, si alguna vez no resultara una torva revelación de escondidos y mortales pudrideros. iSean libres! iNi socialistas, ni anarquistas, ni de círculos católicos! Sean trabajadores. (vol. II, p. 575)

Sicardi limits himself to describing a situation and presenting different political ideas without real consideration of their effect. He gives, by a process of accumulation, the whole range of ideological positions that existed in Argentina towards the end and at the turn of the century. ${ }^{22}$ Although the viewpoint of his narrative is obviously slanted in favour of Elbio and his hard-working followers, it must be remembered that his fiction is peopled mainly by those who are the followers of Ricardo and of Germán. This final point underlines once more the tension existing in this work between fiction and ideological content.

There is another area of tension in Libro extraño, and this concerns the variety of styles which Sicardo uses in this work. Gladys Onega writes of it as 'novela de forma y contenido caóticos'; ${ }^{23}$ Blasi Brambilla says: 'es un complejo mundo, mosaico pululante de observación, enjambre de varias vivencias del escritor, vasto edificio de notas, da escorzos autobiográficos, de retratos, descripciones, tomas de posición estéticas y filosóficas. ....24 This picture of confusion points to a problem of cultural identity, for in his search for a new Argentine identity the author seems torn between the reactionary pull of an artificially inflated Spanish and criollo heritage, and the attractions of modern, scientifically oriented ideas stemming from France, a country with which the progressive Argentine intellectual élite had found particularly close ties. 
Sicardi's prose is characterized by its use of commonplace and inflated rhetoricism. Yet within this tendency a variety of styles is easily detected. The fictional story of Libro extraño is narrated in an overcharged, affected prose, whose dialogues sound stilted and unreal:

No se sentían sollozos, pero de los ojos de Dolores caían las lágrimas grandes y cristalinas, formando surcos en su mejilla, gotas silenciosas que golpean su bata negra mientras otras se atropellan entre los párpados y cuelgan de sus pestañas. No decía una palabra. Miraba al hijo a través de la cortina de sus ojos húmedos, porque las lágrimas son el rocío que mitiga la llama que devora el corazón de los hijos.... El llanto de la madre ha humedecido los ojos del hijo y su palabra le acaricia el oído como una melodía tranquila y santa.

- Tanto que te quiero, Ricardo- le decía la madre. -Yo te perdono.

-iOh mi madre santa!- exclamaba el hijo enternecido.

(vol. II, pp. 188-9)

Within the main fiction there are a number of smaller fictions told by one of the characters in a remote, archaic language. Its express purpose seems to be to reinforce vague ties with medieval Spain, and its vocabulary of falconry, Saracens, snows, and the Crusades, is clearly evocative:

Alto, la tez tostada, en la puerta apareció Valbuena, mientras Ricardo sacaba del bolsillo la roja banda y el ala negra del cuervo, dividida por yatagán sarraceno.

Se acercó lentamente con los brazos rígidos, temblando dentro de aquel mundo de sus adoraciones inmortales.

-iOh contristada flor de la montaña- dijo el caballero, -que tienes el color de las nieves y fríos pétalos, pálida visión de mis noches solitarias de Tierra Santa! iAlma criatura, que has perdido gota a gota tu sangre en las horas de dolor! ... (vol. I, p. 47)

There are not only archaic insertions in the story. Herzen, one of the characters, who according to Blasi Brambilla is an allegory for Darío, ${ }^{25}$ serves to introduce the fashionable and brilliant prose of Modernismo:

La llamé Necros. Así llamaban los griegos a la belleza muerta. Era una flor funeraria, a quien la luz artificial, la luz de las noches insomnes había marchitado la corola, una vestal con la túnica blanca contaminada por el loco estrago. iEra una orgíaca! Cuando la vi una noche bajo la araña de mil luces, sentado en la butaca de terciopelo rojo de una platea, ella sintió como un letargo hondo, porque yo tenía en la mirada alguna siniestra fascinación y conocí que la ponzoña de todo mi cuerpo se derramaba hacia ella en largas hebras, como un vaho letal. (vol. II, pp. 243-4)

Present in Herzen's verse is one of the essential characteristics of modernista 
poetry: the sense of evasion from everyday reality and indulgence in language for its ornamental qualities:

-Yo muero. Contigo el artista, viajero cansado en la tierra contempla sus carnes deshechas y vuela demente contigo en el último estertor de agonía; huraño romero de tétricos soles que hienden el éter! (vol. II, p. 245)

Sicardi is not only attracted to the rich and the elegant. There are in Libro extraño lengthy passages written in a language which is vividly inspired in Zolaesque Naturalism, and drawn to the most morbid excesses of disease and of sin:

Este otro que he ido a ver está enfermo en el cuadro. La sífilis le ha llenado de úlceras la nariz y la boca. Así lo engendraron los padres....

Así desfilan con el cuello partido por las cicatrices de la escrófula, con la nariz roja de alcoholistas precoces, éstos que fueron vagabundos de los figones y de los sucios lupanares, sin más trecho que un tramo de cielo, sin más habitación segura que los esfacelos de un pudridero. Y los conductores no ven nada, ni se puede exigir transformaciones a inteligencias sibaritas. Es inútil enojarse, inútil el anatema. Las cárceles son obscuras y escuelas de vicios, y la niñez sin amparo: los pobres pequeños, que no tienen la culpa del crimen, seguirán entrando y saliendo de los mechinales estrechos, para recomenzar la eterna y desolada historia de la tierra baja, donde hay muchos tristes y muchos abandonados. (vol. II, pp. 467-8)

While no less sentimental than any of the foregoing examples, this extract, with its pseudo-scientific aspirations, shows an interest in ideas which stem from modern French culture and aim at reproducing the impassive Experimental Novel. For the ideological message of his work Sicardi often uses the hollow-sounding discourse of pompous verbosity:

iOh Italia! iEres nuestra hermana! iTus hijos aman la tierra bendita y los nietos crecidos al lado del potro en la salvaje faena, los sudorosos de la fragua o del taller escuchan en la noche la leyenda de tus glorias muertas y las alabanzas de tus sangrientas resurrecciones! Ya lo sabíamos. iNo es posible contar todos los sepulcros de tus grandes! iSobre la tierra eres la reina del arte y más que eso los mártires que han entregado la vida al cadalso y a la ergástula de la tiranía o entre los gritos del combate han hecho posible tu acción civilizadora en la hora presente! (vol. II, pp. 26-7)

This mixture of styles reveals an uncertainty on the part of the author which coincides in every respect with the ambivalence of his general out- 
look discussed earlier. It is a preoccupation with language which can be found not only in the mixture of styles that he adopts, but which is openly discussed within the novel itself. It will be recalled that Pincencurá boasted of only one attribute for his Indian culture and that was the purity of its language. Don Manuel Paloche, the one criollo character who fights for the acceptance of Evolution and who is the propagandist in favour of Immigration, reacts as follows when confronted with a uniformed policeman who does not speak the local language:

-Non capisco- dijo. -iNon sacho! inon sacho!- repitió sin moverse.

-iQué gran país éste!- pensó don Manuel, siguiendo su camino. -Por poco más, la torre de Babel. Éste me ha hablado por lo menos en araucano. Las razas están evolucionando. iVivan las razas! (vol. II, p. 10)

Since Paloche is such an extravagant character, it is difficult to decide at first whether there is sarcasm in his reply, but this becomes evident when viewed against an inflammatory speech given by Paloche at the Sociedad de Artes $y$ de Letras on the need to preserve the purity of the language of Garcilaso and Cervantes. It is curious that Paloche, who in other contexts has welcomed the changes brought about by Immigration, should now say the following:

-Es preciso ir a la lucha. El idioma está pervertido. Se debe guardar como en un templo y defenderlo contra la deturpación. iAtrás el vocablo italiano! Es corruptor. iAtrás el chiste francés! ... Es necesario rechazar los modismos y las palabras creadas en la tierra. (vol. II, p. 92)

The author caricaturizes Paloche's stance at the Sociedad, and calls his speech '(un discurso) estrafalario y poco puesto en razón' (vol. II, p. 91). Yet his own discussion of the problem remains somewhat ambivalent. He fully admits the inevitability of change but betrays a keenly felt resentment both in the pejorative description of outside linguistic intrusions and in the glorification of the original language:

La indumentaria de la honorable concurrencia era variada y pintoresca, el dejo de los sudorcillos bastante políglota y el vocabulario comparable al de la torre de Babel. Su base era el español pero con mezcla abigarrada de neologismos suburbanos, de dicharachos y ternos genoveses, de solecismos gallegos y catalanes, de acentos guturales, que no permiten adivinar el terruño de origen, ronqueras alemanas, gorgoteos de gargantas francesas, estridores agudos de calabreses, de baja estatura, color cobrizo, saco azul que difundían un olorcillo de cebolla pugnando a coces con el jugo gástrico, una mezcla de palabras de todos los idiomas, de giros de todas las gramáticas populares, que herían de muerte la majestad de la lengua madre. Todo esto con la mayor 
naturalidad, como por derecho de conquista. Debía suceder eso. En esta invasión de las razas, así como todas las manifestaciones de la industria, comercio y artes, padecieron la metamorfosis de las nuevas ideas, el idioma fue perdiendo su clásico sabor y maravillosa opulencia. Empezó a ser derrotado y a llenarse de neologismos y de palabras extranjeras. (vol. II, pp. 40-1)

Sicardi's attitude in defence of the preservation of the Spanish language is a further example of his hesitancy between exalting and decrying immigrant influences.

The foregoing analysis of Sicardi's attitude to language has sought to offer another aspect of the general framework against which to place the author's portrayal of Immigration. To summarize, this study has concentrated on the main areas of tension in Libro extraño which affect the portrayal of Immigration in this work. These have been found to exist in the difference between the traditional setting of the fiction and the evolutionary content of the ideologies expressed; in the ambivalence with which the influence of Immigration was regarded with particular reference to the changes effected on the land, in the city, in the ethnic composition of the people, in cultural values and finally in the language. The overall portrayal of the immigrant is confused and equivocal: almost ignored at the aesthetic level, at the ideological level the immigrant is given warm praise for his soberness, his labour and his thrift, whilst gently mocked for pettiness and materialism. But in this ambivalence lies the importance of Libro extraño. It is here suggested that it is more than the example of the personal confusion on the part of the author, and that with it Sicardi has captured the essence of a problem which was besetting Argentine society and which it was uncertain how to resolve. It is in this sense that Libro extraño, in spite of its distorted and over-simplified factual information, must be considered a true testimony of the years in which it was written. 
Having studied the portrayal of immigrant characters in individual works of fiction, it now remains in this concluding chapter to examine the basic pattern which has emerged from the novels under review. The works written in the 'Immigration Period' reveal three charcteristics of the immigrant. First, he is a male youth who arrives from Europe raw and penniless; being ambitious and hard-working he soon achieves financial success. There are no exceptions to this feature of the literary portrayal of the immigrant. Indeed, even in the works studied in the 'Pre-Immigration Period', the industriousness and eventual economic achievement of the immigrants are undisputed assumptions.

The second is that he marries, and the third is that he has a son. These last two events do not apply with the same absolute uniformity as the first. Thus, the immigrant may marry either a compatriot or a criolla who, in turn, may belong to the upper classes or, as in the case of Teodoro Foronda, may be a poor and primitive gaucha, but in every case the union is presented in connection with a racial argument, as the foundation of a new generation. The romantic or affective side of marriage is of little interest and receives scant treatment.

All the immigrants who marry (some minor characters do not) do, subsequently, engender a son. The relationship between the two generations is normally made to illustrate the laws of heredity, the son perpetuating the characteristics of the father, whether these be negative - as in the case of José and of Genaro - or positive - as in the case of Elbio and of Bianchetto's eight sons. It is not surprising, however, to find this rule broken in the only work written by an immigrant author. Grandmontagne views the relationship between first and second generations from within, and therefore sees it not as a continuation but as a confrontation between two irreconcilable beings of a quite different nature. Interestingly, in all other aspects Grandmontagne's novel adheres to the same pattern described above, and indeed, his secondary immigrant characters are basically no different from those created by other authors.

What is noticeable about the portrayal of Immigration in the novels reviewed is its lack of variety as much as the narrowness of its interests. There is an essential poverty in its conception which relates to the 
limitation of the plots which, as seen, conform to one pattern whether presented in a negative or a positive light. This poverty is not merely one of scope but of duration, for the presence of the immigrant seldom occupies more than a few pages. Once more Teodoro Foronda provides the exception for it includes the only immigrant character who remains the centre of interest. The other immigrants are depicted in strong, even strident colours but their presence is not sustained beyond the initial impact. There is somewhat greater interest shown in the sons of immigrants but this is still kept within the boundaries of illustrating heredity.

The basic pattern of the portrayal of immigrants reflects the twin preoccupations of the original Immigration Policy which, it will be recalled, are with work and race. The link between work and the immigrant is presented as axiomatic and in absolute terms; moreover, there are no failures in this respect since all immigrants achieve automatic financial success. The actual process of acquiring wealth is not considered of sufficient interest for elaboration. The question of race is of even greater significance in the literature studied and is treated as more problematic and complex. It concerns the relative merits in racial terms of the immigrant and native populations. It is argued within the following framework: should the immigrant be hailed as a superior leaven come to raise the primitive population from its barbaric stages of underdevelopment or should he be decried as a lowly species, a degenerate corrupting force threatening the pristine quality of life of a pure and spiritual people? These diverging opinions are argued at first from extreme positions on either side and later with compromising ambiguity.

Regardless of the author's position with respect to the above, a feature common to the literature under review is the external vantage point from which it has been conceived. With the partial exception - again - of Teodoro Foronda, the immigrant is viewed from a distance, made into an object of manipulation and reduced to a flat, two dimensional character who serves to illustrate the author's particular ideology. The characterization of a minority group into a stereotype which ignores all individualizing traits, is a feature of all didactic literature and it is here suggested that the portrayal of the immigrant in the works studied is of this nature. A work of art can be defined by its silences as much as by its statements. ${ }^{1}$ Thus the literature under review may be defined by all the relevant material that is absent from it. Many subjects spring to mind in this connection. The almost total lack of an inside view of immigration has already been commented upon; another feature worth noting is the predominantly serious tone with which the subject is treated. As oberved by David Viñas 
the Indian and the gaucho can become the objects of patronizing mirth, but not so the immigrant. ${ }^{2} \mathrm{He}$ may be ridiculed and grotesquely caricaturized but this is invariably done with a heavy hand and seriousness of purpose. This applies only to the novel, not to the more popular short story, or to the theatre.

Furthermore, the novel reflects the absolute dominance that Buenos Aires was acquiring over the rest of the country. With the exception of Facundo, all the works studied are set in the capital and some also partially in the Province of Buenos Aires. The large and numerous colonies that were established in other provinces are not represented in the novel until the works of twentieth century writers such as Gerchunoff, Mateo Booz, Fausto Burgos and others. ${ }^{3}$

There is no description of the difficulties encountered by the immigrants upon arrival on the land when, in spite of lofty promises, there was no provision made for them and they were left without shelter and often without work tools; nor is there any mention of the virtual impossibility of acquiring land, particularly in the Province of Buenos Aires.

Except for some carefully guarded statements by Sicardi, there is no representation of the political refugee from Europe, the immigrant who fled persecution and became an active propagator of subversion in Argentina.

One final important omission noted is that not only is there little description of life in an immigrant community, but there is no portrayal of the clashes and conflicts that took place between immigrants and the gente de pueblo or poorer sectors of society among whom they predominantly lived. All the novels concentrate, instead, on far more unlikely relationships with upper class criollos. ${ }^{4}$

To conclude, the portrayal of immigration in the literature reviewed is narrow, selective, and prescriptive. It reflects less the living experience of the immigrant than it gives an insight into the mixed reactions that Immigration elicited from some of the leading intellectuals of the country. 


\section{FOOTNOTES TO PART ONE, TWO, THREE, AND CONCLUSION}

\section{INTRODUCTION}

1 G. Onega, La inmigración en la literatura argentina, 1880-1910 (Buenos Aires, 1968).

2 L. Rusich, El inmigrante italiano en la novela del 80 (Madrid, 1974).

3 See articles in Inmigración y nacionalidad, by Dardo Cúneo et al (Buenos Aires, 1967).

4 G. García, El inmigrante en la novela argentina (Buenos Aires, 1970), p. 27.

5 G. Onega, op.cit., p. 32.

6 See D. Viñas, Grotesco, inmigración y fracaso (Buenos Aires, 1973).

7 L. Goldman, Pour une sociologie du roman (Paris, 1964), p. 345.

8 See R. Barthes, S/Z (London, 1975), p. xi.

PART ONE:

I . "FACUNDO: CIVILISACIÓN Y BARBARIE"

1 Juan Loveluck, 'Los orígenes de la novela hispanoamericana', in La novela hispanoamericana, edited by J. Loveluck (Concepción, 1966), pp. 15-16.

.2 Pedro Henríquez Ureña, 'Apuntaciones sobre la novela en América', in La novela bispanoamericana, op.cit., p. 23.

3 Juan Antonio Portuondo, 'El rasgo predominate en la novela latinoamericana', in La novela ..., op.cit. pp. 121-9.

4 Ezequiel Martínez Estrada, Para una revisión de las letras argentinas (Buenos Aires, 1967), pp. 73-4.

5 Esteban Echeverría, El Matadero (Buenos Aires, 1965), pp. 80-96. The exact date when El Matadero was written is not known, although most literary historians and critics place it around 1838-9. Anderson Imbert, in Spanish American Literature (Michigan, 1969), I, p. 222, places it between 1837 and 1840 , but the earlier date seems unlikely as the story is set during the years in which it was mandatory to wear a sign of mourning for the death of Rosas's wife, i.e. between 1838 and 1840 (see Arrieta, Historia de la Literatura Argentina (Buenos Aires, 1958-1960), II, p. 94. The story was published posthumously in 1871 by Ricardo Gutiérrez.

6 E. Echeverría, op.cit., pages 86 and 92 respectively.

7 A similar point is made, in a different context, by Eric Auerbach, who writes about 'the ... peculiarity of the ancients' way of viewing things; it does not see forces, it sees vices and virtues, successes and mistakes. Its formulation of problems is not concerned with historical developments either intellectual or material, but with ethical judgements', in Mimesis (New Jersey, 1973), p. 38 . 
8 José Mármol, Amalia (Buenos Aires, 1885). The work was first published in 1851 (in Montevideo) in a shorter version, which was much enlarged by documental material after the fall of Rosas, and republished in its augmented form in 1855, in Buenos Aires.

9 Domingo Faustino Sarmiento, Facundo: Civilización y barbarie (Buenos Aires, 1845). All page references will be made to the following edition: 'El libro de bolsillo', Alianza Editorial (Madrid, 1970).

10 Italics are mine.

11 Paul Verdevoye, Sarmiento: Educateur et Publiciste, (Paris, 1964), pp. 500-2 and 544-5.

12 A. Castro Leal, 'El Facundo de Domingo Faustino Sarmiento', in Cuadernos americanos, IV, 5, (1945), p. 148.

Dardo Cúneo, in Sarmiento y Unamuno, (Buenos Aires, 1963), p. 70. Unamuno is quoted as having said: 'siempre me pareció una obra literaria, una verdadera novela con base histórica'.

Allison N. Bunkley, The Life of Sarmiento, (New Jersey, 1962), pp. 221-2.

For a differing view see Alberto Palcos, El 'Facundo': Rasgos de Sarmiento, (Buenos Aires, 1945), p. 67.

13 Palcos (see reference Note 12), pp. 72-4, recounts that when Alsina objected to the exaggerated prowesses that Sarmiento ascribed to the gauchos, saying for example, that the 'gaucho malo' could hardly have known the horses of 'ten thousand' estancias at a time when there were hardly 'one hundred', and to know those of 'ten' was already quite a feat, Sarmiento acknowledges the comment and modifies his figure. Instead of ten thousand he writes 'one thousand' estancias. Palcos adds: 'véase lo que es el fino instinto del artista. Sarmiento emplea aquí la hipérbole porque esclarece los contornos de una verdad fundamental'.

14 Hyppolite Taine, 'Introduction to the History of English Literature', in Revue Germanique et Française, (1863).

15 The term gaucbo needs qualifying. Its origin is the object of a continued polemic, described in detail and with copious references by J. Corominas, in his Diccionario crítico etimológico de la lengua castellana, (Madrid, 1954), pp. 706-7. But whatever its origins, the word has suffered in the nineteenth century a semantic change parallelling the historical development of the country, and what once stood for the intrepid and feared centaur, the freelance cattle-herd, or the fierce fighter on the battlefield, is often used in Facundo, and in subsequent works, to mean no more than the poor uneducated inhabitant of the rural areas of Argentina.

16 Darwin writes: 'as natural selection acts by competition, it adapts the inhabitants of each country only in relation to its associates; so that we need feel no surprise at the inhabitants of any one country, although on the ordinary view supposed to have been specially created and adapted for that country, being beaten and supplanted by the naturalized productions from another land', Charles Darwin, On the Origin of Species by Means of Natural Selition or the Preservation of Favoured Races in the Struggle for Life, (London, 1950), p. 399.

17 The definition of Criollo is as follows: 'Del Portugués crioulo, blanco nacido en las colonias, y más tarde esclavo negro nacido en casa del señor. Deriv. de criar y cría. adj.Amér. Dícese del nacido en tierra hispanoamericana, sea 
descendiente de extranjeros o nativos.', Diccionario de Americanismos, (Buenos Aires, 1966). This explains the wide range of the term, which is used for the high-ranking local élite, down to the native mestizo masses. In this instance, it obviously refers to the latter meaning.

18 At the time of writing Facundo in 1845, Sarmiento based his description of the pampas on his reading and on his imagination. His first visit to that part of Argentina was made in 1851. See Palcos, El 'Facundo': Rasgos de Sarmiento, p. 36, and C. A. Jones, Sarmiento: 'Facundo', (London, 1970), pp. 9-19.

19 See Bunkley, The Life of Sarmiento, p. 50.

20 ibid., pp. 216-18.

21 Quiroga fought against Paz at La Tablada on 23 June 1829, and at Oncativo on 25 February 1830. He was defeated on both occasions.

22 The concept of physiognomy can be traced as far back as Aristotle. Modern exponents began with Lavater's work in 1772, and the idea was widely used in the nineteenth century.

23 Noé Jitrik, Muerte y resurrección de Facundo (Buenos Aires, 1968).

24 On Rivadavia's Plan of Unification, see H. S. Ferns, Argentina (London, 1969), pp. 78-80.

25 Jitrik, op.cit., pp. 51-69.

26 A positive image of Federalism can be found in popular poetry, in the cielitos and in the payadas.

27 Emiliano Diez-Echarri, Historia de la literatura espanôla e bispanoamericana, second edition, (Madrid, 1966), p. 908.

28 Facundo, p. 139. Note the importance that Sarmiento attaches to dress. This will become a significant feature of the literature studied.

29 Jitrik, op.cit., p. 37.

30 This diagram can be seen to coincide with Myron Burgin's triangular division of political and economic interests in post-Independence Argentina. Facundo can be said to represent the Federalist interests of the Interior, Rosas the quite opposite Federalist interests of Buenos Aires Province, and Paz the Unitarians, who differed only from the porteño Federalists in that they wanted to share the port's revenue with the whole nation. See Appendix pp. 310-12.

31 Miguel de Unamuno, in La Nación, April 1916, quoted in Dardo Cúneo, Laspropias vanguardias, (Buenos Aires, 1973), p. 52. Commenting on this line of criticism, J. L. Borges writes: 'paradójicamente, Sarmiento ha sido motejado de bárbaro. Quienes no quieren compartir su aversión por el gaucho, afirman que él también era un gaucho, equiparando de algún modo el ímpetu bravío del uno en las disciplinas rurales, con el ímpetu bravío del otro en la conquista de la cultura.', Prólogos, (Buenos Aires, 1957), p. 132.

32 This assertion, and the passages illustrating it, contradicts Diez Echerri's statement that 'por lo demás, no aspira a exterminar el gaucho sino a educarle', Diez-Echarri, op.cit., p. 908. 


\section{PART ONE:}

\section{II - "PEREGRINACIÓN DE LUZ DEL DÍA"}

1 J. R. Scobie, Argentina: A City and a Nation (New York, 1971), p. 107.

2 J. B. Alberdi, Bases y puntos de partida para la organización política de la República Argentina (Buenos Aires, 1852). All references to this work will be to the edition of La cultura argentina, (Buenos Aires, 1960).

3 This debate can be followed in J. B. Alberdi's Las Quillotanas, o cartas sobre la prensa y politica militante (Buenos Aires, 1853).

4 W. R. Crawford, A Century of Latin American Thought (Cambridge, Massachusetts, 1963), p. 20.

5 See Appendix, page 214.

6 J. Franco, An Introduction to Spanish American Literature (London, 1968).

7 E. Anderson Imbert, Spanish American Literature (Michigan, 1969), I, pp. 224-5.

8 Crawford, op.cit., p. 26.

9 R. Saenz Hayes in R. A. Arrieta, Historia de la literatura argentina, op.cit., vol. 2, pp. 359-60.

10 ibid., p. 361.

11 R. Rojas, Historia de la literatura argentina, 9 vols (Buenos Aires, 1960, VI, pp. 577-88.

12 Peregrinacion de Luz del Día o Viaje y Aventuras de la Verdad en el Nuevo Mundo, by J. B. Alberdi (Buenos Aires, 1871). All future references will be to Luz del Día en América (Buenos Aires, 1916).

13 It is surely wrong to talk about Luz as 'he', as do Anderson Imbert (op.cit., p. 224 n.) and M. Lichtblau, The Argentine Novel, (New York, 1959), p. 106.

14 M. Rhode, Las ideas estéticas en la literatura argentina, 4 vols (Buenos Aires, 1921-6), III, pp. 210-11.

15 This point is an indirect reflection of Zum Felde's thesis that European literature deals with moral and universal themes whereas Latin American literature is preoccupied more exclusively with immediate social and political problems. See A. Zum Felde, Indice crítico de la narrativa bispano-americana, 2 vols, (México, 1954), I, pp. 7-22.

16 See Cornelius de Pauw, Nouvelle Biographie Générale, 45 vols (Paris, 1852).

17 This is fully examined in A. Gerbi, La Disputa del Nuevo Mundo, (México, 1960).

18 A General History of the Americans: Selected from M. Pauw, (i.e. C. de Pauw), by Daniel Webb, Esq., (Rochdale, 1806), pp. 17-18.

19 A. Gerbi, op.cit. p. 29.

20 Peregrinación de Luz del Día, prologue by M. García Mérou, p. 7.

21 See Luz del Dia Chapter 25: 'También en Norte América, como en la vieja europa está la mentira', pp. 293-7.

22 See his bitingly satirical article in La Moda, 'Guerra a los extranjeros y al extranjerismo', published in a selection from Alberdi's Escritos Póstumos (Buenos Aires, 1945).

In it Alberdi pretends to blame the extranjeros for a list of imports such as printing houses, liberal ideas, text books for schools, ships, transportation, furniture, etc., all things which Alberdi clearly favours. He goes on to say that 
it is a mark of treason to admire them because they stem from Europe, but he warns the pro-nationals that to practice despotism and barbarism is no less of a way to succumb to foreign influences, since Calígula, Nero and Machiavelli were European too.

23 For an ordered resumé of the proposed political programme, see Luz del Dia, Part III, Chapter XXI and XXII.

24 On the sacrosant attitude adopted towards patriotism and military glory, Jorge Luis Borges has the following to say:

To suggest, for example, that perhaps - you know that we have a national hero called José de San Martín, you may have heard of him, no? The Argentine Academy of History decided that no ill could be spoken of him. I mean, he was entitled to a reverence denied to the Buddha or to Dante or to Shakespeare or to Plato or to Spinoza and that was done quite seriously by grown-up men, not by children. And then I remember a Venezuelan writer wrote that San Martín 'tenia un aire avieso'. Now avieso means sly, but rather the bad side, no? And then Capdevila, a good Argentinian writer, refuted him in two or three pages, saying that those two words, avieso - sly, cunning, no? - and San Martín, were impossible, because you may as well speak of a square triangle.

See Richard Burgin, Conversations with Jorge Luis Borges (London, 1973), p. 32.

25 Alberdi, Bases, p. 153. For a fuller discussion of 'gobernar es poblar', see pp. 152 to 171.

26 D. F. Sarmiento, Obras Completas, 53 vols (Buenos Aires, 1900), 38, p. 421. See also p. 286 of Luz del Día ...:

No se alucine Sud-América con su fértil suelo. Su fertilidad no le dará riqueza, que vive en el hombre laborioso, no en el suelo. No hay mejor medio de traer riquezas y capitales extranjeros al país, que traer inmigraciones de trabajadores inteligentes y laboriosos.

27 B. Canal Feijóo, Constitución y Revolución: Juan Bautista Alberdi (Buenos Aires, 1955), pp. 392-4. (For an attempt to recognize certain well-known figures in Argentine politics as personajes claves in Peregrinación, see ibid., pp. 524-5).

28 It is interesting to note that the distinctions that Alberdi draws between 'spiritual' Latins and 'materialistic' Anglo-Saxons, is the same as Rodó makes in Ariel. But what is considered by Alberdi as a positive quality, is viewed by Rodó in a more negative light: see J. E. Rodó, Ariel (London, 1967), pp. 72-92.

29 See Appendix, p. 223.

30 In Bases, Alberdi repeats the theme that 'El Inglés es el más perfecto de los hombres' (p. 61). His plan to attract the British and to avoid being conquered by them is based on the following picturesque suggestion:

La América del Sud posee un ejército a este fin y es el encanto que sus mujeres hermosas y amables recibieron de su origen andaluz mejorado por el ciclo espléndido del Nuevo Mundo. 


\section{PART TWO:}

\section{I - BACK GROUND TO THE LITERARY SCENE}

1 Roca's first period Presidency went from 1880 to 1886.

2 See Appendix, page 224.

3 Present research is engaged upon studying a wealth of 'sub literary literature', or popular writings which may reveal a different picture, but its findings are, as yet, unpublished.

4 See R. Rojas, Historia de la literatura argentina, VIII, pp. 384-5. Also, for a resumé of the subject matter of novels written between 1850-70, see Myron Lichtblau, The Argentine Novel in the Nineteenth Century (New York, 1959), pp. 30-100; and E. Martínez Estrada, Para una revisación de las letras argentinas, pp. 82-4.

5 L. Kolakowski, Positivist Pbilosophy (London, 1972), pp. 78-9.

6 M. I. Lichtblau, The Argentine Novel in the Nineteenth Century, p. 160. Further references to this book are given after quotations in the text.

7 This is the basic definition of Realism on which R. Wellek centres his discussion on the subject. See R. Wellek, Concepts of Criticsm (New Haven, 1963), pp. 240-1.

8 J. Franco, Introduction to Spanish American Literature, p. 95.

9 Stendhal, Le Rouge et le Noir, epigraph to Chapter XIII. See R. Wellek. op.cit., pp. 248-9.

10 M. Lichtblau, op.cit., pp. 163-84. In this chapter are included the works of Cambaceres, Argerich, Sicardi, whereas Bianchetto and Teodoro Foronda are discussed under the subheading of 'The Immigrant Revealed in the Realistic Novel', pp. 158-60.

11 G. Onega, La inmigración en la literatura argentina, pp. 85-129.

12 G. Ara, La novela naturalista en Hispanoamérica (Buenos Aires, 1965), pp. 1934.

13 J. Franco, op.cit., pp. 93-4.

14 E. Zola, Le roman experimental (Paris, 1800), pp. 3-4.

15 See D. D. Runes, Dictionary of Philosophy (London, 1972).

16 Zola, op.cit., p. 28.

17 G. Onega, op.cit., pp. 88-9.

\section{PART TWO:}

\section{II · "INOCENTES O CULPABLES"}

1 G. García, El inmigrante en la novela argentina, p. 51.

2 Antonio Argerich was born in Buenos Aires on 2 September 1855, and died in Catamarca on 2 August 1940: see Gran Enciclopedia Argentina (Buenos Aires, 1956) and Enciclopedia de la literatura argentina (Buenos Aires, 1970). He was a writer, a journalist, and a stock farmer. Although a member of the well-known medical family of the same name, Argerich himself was not a doctor, as suggested by Guillermo Ara in La novela naturalista en Hispanoamérica (Buenos Aires, 1965), pp. 20 and in Los argentinos en la literatura nacional 
(Buenos Aires, 1966), p. 109. The point is of some relevance regarding some 'scientific' assertions made by this author.

3 G. Onega, La inmigración en la literatura argentina, p. 23.

4 G. García, op. cit., p. 24: M. Lichtblau, The Argentine Novel in the Nineteenth Century, p. 174; L. Rusich, El immigrante italiano en la novela argentina del ochenta, p. 86.

5 A. Argerich, Inocentes o culpables (Buenos Aires, 1884).

6 Malthus (1766-1834) argued that the increase of population will take place, if unchecked, in a geometrical progression, while the means of subsistence will increase only in an arithmetical progression.

7 Argerich introduced the cross-breeding of cattle to the province of Catamarca: see article on Argerich in Gran Enciclopedia Argentina, op. cit.

8 It is interesting to see how a similar concept, i.e. 'los rezagos fisiológicos de la vieja Europa', is used differently in the U.S.A. and in Argentina. The inscription on the Statue of Liberty calls explicitly for:

Give me your tired, your poor,

Your huddled masses yearning to breathe free,

The wretched refuse of your teeming shore,

Send these, the homeless, tempest tossed, to me:

I lift my lamp beside the golden door.

E. Lazarus, The New Colossus: Inscription for the Statue of Liberty, New York Harbour.

9 G. Ara, op.cit. pp. 25-6.

10 L. Rusich, op.cit. pp. 89-90.

11 M. García Mérou, Libros y autores (Buenos Aires, 1886), pp. 31-2.

12 M. Lichtblau, op.cit. p. 174.

13 The idea of categorizing different races according to a hierarchical set of values, is found in the writings of Count Gobineau, influential in Europe and in Latin America from the mid-nineteenth century onwards: see J. Franco, Culture and Society, p. 44. Gobineau claimed that degeneration is caused by miscegenation between races: see M. D. Biddiss, Father of Racist Ideology: the Social and Political Thought of Count Gobineau (New York, 1970), pp. 114-15.

14 G. Onega, op.cit. p. 87, and also F. Sicardi, Libro Extraño, II, p. 44.

15 A. Argerich, 'Naturalismo, disertación leída en Politeama, con motivo de la velada literaria a beneficio de Gervasio Méndez', (Buenos Aires, 1882).

16 The following lines provide an example of the scientific pretensions of the author and his use of medical terms:

Las jóvenes excitadas por la atmósfera cargada del salón presentaban en sus mejillas unas placas moradas, signo característico del temperamento linfático y de la pobreza fisiológica de sus constituciones.

Inocentes o culpables, p. 206. Ironically in the terms of the novel, the girls' chances of marrying into high criollo society are marred not by their physiological, but by their financial poverty.

17 This point will receive fuller treatment in the next chapter, in conjunction with a study of En la sangre.

18 M. García Mérou, op.cit. pp. 29-30.

19 ibid. p. 33. 


\section{PART TWO:}

\section{III · "EN LA SANGRE"}

1 R. Rojas, Historia de la literatura argentina, op.cit., VIII, p. 392.

2 In his work on The Nature of Prejudice, G. W. Allport writes:

A subtle and attractive mystery surrounds the concept of 'blood'. There is a definiteness, an intimacy, a symbolic importance hovering around this shibboleth. Both family and racial pride focus on 'blood'. This symbolism has no support from science. Strictly speaking, all blood types are found in all races. Yet people who exalt 'blood' do not know they are speaking in a metaphor, they think they are talking about scientific reality. Gunnar Myrdal, in writing about Negro-White relations in America, correctly saw that this mythical symbol had stark and solid consequences.

G. W. Allport, The Nature of Prejudice (Cambridge, Massachusetts 1955), p. 110 .

3 J. Lynch, Spain under the Hapsburgs, 2 vols (Oxford, 1965), I, pp. 27-8.

4 This characteristic of racialism is noted by G. LeBon in L'évolution psychologique des peuples (Paris, 1894), p. 13.

5 E. Cambaceres, En la sangre (Buenos Aires, 1967). All page references will be to this edition.

6 E. Cambaceres, Sin Rumbo (Buenos Aires, 1885). On the significance of bastío in Sin Rumbo, see Noé Jitrik, Ensayos de literatura argentina (Buenos Aires, 1970), pp. 36-7.

7 For a more objective account of land development and the part played by immigrants, see Appendix, pp. 219-20. It is interesting to note that Antonio Cambaceres, the author's father, introduced changes in the cattle industry that greatly increased its productivity: see Diccionario Histórico Argentino (Buenos Aires, 1853-4), under Cambaceres.

8 G. Onega, El inmigrante en la literatura argentina, pp. 91-2.

9 Here, it may be remarked that in his sociological study G. Le Bon states that inferior races form homogeneous groups, whereas more developed races are prone to social stratification. See Le Bon, op.cit., p. 37.

10 This point also illustrates the fact mentioned earlier that in this work environment is considered as an influence which can work hand in hand with heredity in that it can aggravate its deleterious effect but which in itself is not sufficiently strong to act independently.

11 On this point, D. Viñas writes:

En la otra punta, el gringo inmigrante de 1887: si un hombre de abajo no recibe órdenes ni las espera, entraña un peligro; sus 'entradas' no son apariciones que soporten la pertinente brusquedad del 'mozo de servicio' que entra tropezando con la alfombra para caer y hacer reír: es el 'trepador' (cuando el narrador lo contempla desde arriba) o el 'invasor' (cuando ese desnivel se despilfarra) y ambos se connotan como hombres nuevos. Si todo el país en un 'escenario' donde los gentlemen-políticos predominan como los 'grandes actores' de acuerdo a la espectacularidad genérica de la concepción liberal de la historia, un 'desconocido de todos' en medio de esa 'escena' total sólo puede ser visto como un 'intruso': se lo había convocado para que permaneciese entre cajas o se le toleraban apariciones 
esporádicas y divertidas. Ni siquiera venía precedido de algún prestigio épico para transfigurarlo en 'mito gaucho' o cierta ferocidad trágica que -convertida- se tornase 'santidad indígena'. El avance del gringo y de sus hijos esboza para el señor una derrota, 'esos' transitan por el mundo y el mundo deja de ser solo de ellos. Todas las convicciones que convergían sobre el gentleman también derivan hacia un nuevo centro: el mundo se le escurre de entre las manos y su ser incuestionable padece un 'derrame' que lo arroja a una existencia subjetiva. Los objetos se desdoblan: una cara hacia 'los de siempre'; otra, distinta, hacia 'ellos'. Que no se limitan a escamotearles la 'ciudad', sino que amenazan con privarlos de ellos mismos: 'Hemos sido sorprendidos por estos tipos' se alarman los gentlemen. Y Cambaceres se los describe: ya dejan de formar con 'el país' esa totalidad equilibrada que creían inmutable. Los 'hombres nuevos' tienen poder sobre los señores: 'Me miran a su manera', 'piensan de mí lo que quieren'. En el ámbito naturalista, por lo tanto, el gringo ciudadano 'no hace reír a nadie'; tendrá que esperar al sainete elaborado por hijos de inmigrantes que conjuran a su padre.

D. Viñas, De Sarmiento a Cortázar (Buenos Aires, 1971), pp. 38-9.

12 See W. C. Booth, The Rbetoric of Fiction (London, 1961), pp. 3-20.

13 Pelechau comes from pelecha, which in Argentina refers to a snakeskin found on the fields. From this, the first meaning of pelechar is 'cambiar el pelo los animales', the second being 'prosperar, mejorar de fortuna o posición', Diccionario de Americanismos, op.cit.

14 It is suggested on p. 73 that Genaro's father was in fact from Calabria and not from Naples, but it is clear that in Cambaceres's prejudiced outlook all parts of Southern Europe seem interchangeably despicable.

15 See Appendix, pages 230-1.

16 T. Veblen, The Theory of the Leisure Class (London, 1970), pp. 236-7.

17 This is yet another example of Cambaceres's thorough exposition of his theories. In contrast thereto, Argerich endowed an intelligent character, Dr Ferreol, with a stupid mother and no father. See page 98.

18 A. O. Blasi Brambilla, Los Fundadores (Buenos Aires, 1962), p. 34.

19 E. Cambaceres, Obras Completas, Observaciones y notas por E. M. S. Danero, (Buenos Aires, 1968), p. 11.

20 Teresita Frugoni de Fritzsche, Introduction to Sin Rumbo (Buenos Aires, 1968), p. 43.

21 For a more detailed account of life in conventillos, see: A. J. Scobie, Buenos Aires: Plaza to Suburb. 1870-1910 (New York, 1974) pp. 147-51.

\section{PART TWO:}

IV - "LA BOLSA"

11891 Edición La Nación.

1998 Edición Artística Buenos Aires, prólogo de Julio Picquet.

1905 Biblioteca de La Nación, vol. 175.

1938 Colección Grandes Escritores Argentinos.

1942 Biblioteca Clásica Americana, vol. I. 
1943 Editorial Emecé.

1944 Colección Grandes Escritores Argentinos, vol. 21.

1946 Clásicos Argentinos, Editorial Estrada, vol. XXI.

1956 Edición Kraft, Próloge de Adolfo Mitre. Reprinted in 1971.

There is a certain amount of confusion about the exact date of the first edition of the novel in book form. According to most critics, among whom O. Blasi Brambilla in Los Fundadores; Giusti in R. A. Arrieta's Historia de la literatura argentina; A. Mitre in his Prologue to the Estrada edition, the novel was not published until 1898, after the author's death, by Edición Imprenta Artística Buenos Aires. Yet the writer has seen and handled in the British Library a volume published by La Nación dated 1891. The British Library's stamp denoting the date of acquisition reads 30 July 1892. M. Lichtblau also talks of this edition.

2 R. Rojas, Historia de la literatura argentina (1917-1921), VIII, pages 413 and 417.

3 See note 15 of En la sangre.

4 It will be recalled that an early inkling of the impending crisis was found in the last chapters of En la sangre (1887). Works which deal with the subject more directly are: M. Bahamonde, Abismos (Buenos Aires, 1890); J. Martel, La Bolsa (Buenos Aires, 1691); C. M. Ocantos, Quilito (Paris, 1891); S.I. Villafañe, Horas de Fiebre (Buennos Aires, 1891); E. de Ezcurra, Buenos Aires en el siglo XX (Buenos Aires, 1891); A. del Solar, Contra la marea (Buenos Aires, 1894); P. G. Morante, Grandezas (Buenos Aires, 1896); F. Grandmontagne, La Maldonada (Buenos Aires, 1898); J. L. Cantilo, Quimera (Buenos Aires, 1899); O. Saaveda, Grandezas chicas (Buenos Aires, 1901); E. Gouchón Cané, El 90: see Capitulo, Centro Editor de América Latina' (Buenos Aires, 1967), 22, p. 521.

5 Sergio Bagú is wrong when he says that Martel's work was the only account in fiction, although the point is important only for the sake of accuracy, since most of the other works, with the possible exception of Qwilito, are both unknown and unobtainable; see 'Julián Martel y el realismo argentino', separata de la revista Comentario (Buenos Aires, 1956), p. 5.

6 See all the works reviewed in this thesis, and also R. Payró, Las divertidas aventuras del nieto de Juan Moreira (Buenos Aires, 1971) and J. S. Alvarez (Fray Mocho), Cuentos de Fray Mocho (Buenos Aires, 1906).

7 In a discussion on the subsistence of anti-semitism in a nonreligious context, it was suggested that 'anti-Semitism in all of its varieties was, at its very root, a form of xenophobia, the hatred of a stranger - the oldest, most complicated and most virulent example of such hatred', Encyclopaedia Judaica (Jerusalem, 1974), article on 'Anti-semitism'.

8 J. Martel, La Bolsa (Clásicos Argentinos, Buenos Aires, 1971). All page references are to this edition.

9 See D. Viñas, De Sarmiento a Cortázar, pp. 229-31.

10 D. Viñas, 'Martel y los cupables del 90', in Literatura Argentina y realidad política, (Buenos Aires, 1964), pp. 240-7.

11 E. A. Drumont, La France Juive, 2 vols (Paris, 1886).

12 ibid., I, p. 31.

13 ibid., II, p. 58. 
ibid., pages 35 and 34, respectively, in vol. 1 .

15 T. Veblen, The Theory of the Leisure Class, p. 30.

16 B. Lewin, Cómo fue la inmigración judia a la Argentina (Buenos Aires, 1971).

17 ibid. p. 78.

18 A dissenting opinion can be found in Magis, who writes: 'la aparente contradicción en el personaje de Glow es en rigor un típico espíritu burgués ... ordenado, fariseo, maleable, subyugado por la única pasión posible: el lucro’. In his anti-capitalist fervour, this critic overlooks the stark inconsistency between Glow's alleged sharpness of mind and the naïveté with which, to name but one instance, he invests in the setting up of a liqueur factory. C. H. Magis, La literatura argentina (México, 1965), pp. 206-7.

19 See p. 83 of this thesis.

20 M. Lichtblau, The Argentine Novel in the Nineteenth Century, p. 150.

21 Margarita, his wife, is also an ambivalent character. She is the daughter of the noble criollo élite Martel is trying to defend. Yet not only is she ambitious and greedy, but it is her suggestion to have all assets placed in her name to defraud the creditors.

22 See Appendix, pages 214-6.

23 The idealization of the past in terms of a noble, disinterested, spiritual time, is put forward merely as a strong counterbalance to the hated present. This would conform with Allport's findings that 'the legend of a Golden Age intensifies ethnocentrism', and is one of the important cultural devices to ensure loyalty and withstand changes from outside. See G. W. Allport, The Nature of Prejudice, p. 236.

24 A. Mitre, Prologue to La Bolsa, p. viii.

25 N. Jitrik, El 80 y su mundo (Buenos Aires, 1968), p. 33: 'En apariencia, todo ésto suscita un renacimiento no muy brillante en el momento, del criollismo cuya apelación se convertirá en una constante: el criollismo será un sentimiento de repuesto que será enterrado y desenterrado cada vez que el grupo se sienta seguro o amenazado'.

26 This point is discussed more fully in the Appendix. See pp. 335, 342-3.

27 See pages $38-9$ of this thesis.

28 For a list of these see L. Rusich, El inmigrante italiano ... (p. 158) The name of R. Rojas is notably absent.

29 See D. Viñas, 'Martel y los culpables del 90', p. 253. There is evidence in support of this. B. Lewin states that there were only 1,500 Jews in Argentina in 1888 , as the result of spontaneous immigration, and that mostly they lived in the provinces, away from the capital. Even the one hundred and fifty families who arrived as the first wave of immigration from Russia, were all settled on the land (see B. Lewin, op.cit., p. 106 According to figures researched by Lewin, among the Jewish community of Buenos Aires, only eight weddings, twenty six births, and five deaths, took place in three years, from 1883 to 1886 (ibid. pp. 67-8).

op.cit., p. 106 According to figures researched by Lewin, among the Jewish community of Buenos Aires, only eight weddings, twenty six births, and five deaths, took place in three years, from 1883 to 1886 (ibid. pp. 67-8).

30 This point is discussed more fully in: J. Katz, 'A State within a State: The History of an Antisemitic Slogan' Proceedings of the Israel Academy of Sciences and Humanities, IV, No. 3, pp. 29-58. 
31 "The word "racism", a coinage of the 1930s, was unknown to Gobineau and its use in connection with him is, in a sense, anachronistic. Yet the retrospective attribution is justified because he does provide a strikingly systematic example of Race used as the sole or primary instrument of historical, social, and political explanation in the pseudo-philosophical manner that subsequently became too familiar', M. D. Biddiss, Father of Racist Ideology, p. 105.

32 S. Bagú, 'Julián Martel y el Realismo Argentino: Una Revaloración de La Bolsa', op.cit., p. 11.

33 See page 157.

34 E. Drumont,La France Juive, p. 57.

35 ibid. p. 59.

36 ibid. p. 19.

37 ibid. p. 92.

38 G. Onega, La inmigración ..., op.cit., p. 118.

39 L. Rusich, El inmigrante italiano ..., op.cit., p. 161, note 9.

40 S. Bagú, op.cit. p. 13.

41 B. Lewin, op.cit. pp. 119-23.

42 ibid. pp. 123-4.

43 On this, Martel writes the following:

No ignoraba el doctor que aquel semita era un enviado de Rothschild, el banquero inglés, que lo había mandado a Buenos Aires para que operase en el oro y ejerciese presión sobre la plaza. Lo que el doctor no sabía era que Mackser tenía la consigna de acaparar, de monopolizar, con ayuda de un fuerte sindicato judío, a cuyo frente estaba él, las principales fuentes productoras del país (pp. 32-3).

\section{PART THREE:}

\section{I - THE CHANGING CONTEXT}

1 E. Rodó, Ariel (Montevideo, 1900). See J. Franco, The Modern Culture of Latin America, chapter on 'The Selct Minority: Arielism and Criollismo, 1900-1918', pp. 40-68. See too footnote 25 of chapter on La Bolsa.

2 R. Güiraldes, Don Segundo Sombra (Buenos Aires, 1926).

\section{PART THREE: \\ II · "BIANCHETTO"}

1 A. Saldías, Bianchetto: La patria del trabajo (Buenos Aires, 1896).

2 Saldías's Historia de la Confederación Argentina 1829-1862, 5 vols., published in 1892, is the first attempt in Argentine history at a revisionist account of the Rosas regime based upon archival documentation rather than on politically subjective criteria. See Diccionario Histórico Argentino.

3 A. Saldías, La condition des étrangers residents (Paris, 1889).

4 F. Lajouane, Prologue to Bianchetto, pp. v-vi.

5 Saldías himself belonged to the Alsinistas group, in whose cause he fought actively. Moreover, he was successively deputy, senator, and vice-governor of the Province of Buenos Aires. See Diccionario Histórico Argentino. 
6 All italics in quotations from Bianchetto belong to Saldías.

7 M. R. Lida de Malkiel, Horacio en la literatura mundial (Buenos Aires, 1975), pp. 262-5.

8 ibid., pages 335-9.

10 L. Rusich, El inmigrante italiano en la novela argentina, pp. 196-7).

11 This is yet another indication of the atypical, didactic nature of this work. Immigrants did not normally perform the same tasks as the gauchos, but were involved in the agricultural aspects of land-farming, something which the cattle-raising gaucho despised. See Appendix, page 319.

12 See Appendix, page 328.

13 J. Hernández, Martín Fierro (Buenos Aires, 1953).

14 L. Rusich, op.cit. p. 200.

\section{PART THREE:}

\section{III · TEODORO FORONDA}

1 G. García, El inmigrante en la novela argentina, p. 39.

2 A. Gerchunoff was born in Russia and came to Argentina when he was five years old. He spent his youth on the land and, in 1895, moved to Buenos Aires where he soon gained fame as a journalist and as a writer. From 1908 onwards he worked for La Nación.

3 J. Valera, Ecos Argentinos (Madrid, 1901), p. 172-3.

4 G. Onega, La inmigración en la literatura argentina, p. 174.

5 F. Grandmontagne, Teodoro Foronda (Buenos Aires, 1896). All page numbers will refer to this edition.

6 Gaucha: this is an unusual use of the feminine form of the word gaucho. The Diccionario de Americanismos defines gaucha as mujer varonil, but this is clearly not the sense in which it is used here, since María is characterized by her passive, docile behaviour. It illustrates, therefore, the semantic change undergone in the nineteenth century by the word gaucho, which came to be used almost synonymously with peón or farm-hand.

7 Everything in the work points to Foronda's death, allthough the ending is left open merely to enable the author to continue the family's history in another work, La Maldonada, published two years later.

8 L. Kolakowski, Positivist Philosopby, p. 123.

9 J. Martel, La Bolsa, p. 21.

10 See Appendix, Section I, note 16, pp. 322-3.

11 Foronda's rejection of María lies in the tradition of belief in the white man's racial superiority. It bears a close resemblance to that depicted in $\operatorname{Sin} R u m b o$, whose arrogant and world-weary protagonist, Don Andrés, also feels disgust at the coarseness of his rural mistress Donata. Racial prejudice is the one issue on which the upper-class criollo and the struggling immigrant can be seen to coincide. See E. Cambaceres, Sin Rumbo, op.cit.

12 This reaction is recorded in D. Rock's study of the growth of the Radical Party, where he notes the marked tendency of second generation immigrants to wish to disassociate themselves from their origins and adopt the values and life-style of middle-class criollos. D. Rock makes this observation in an 
attempt to explain the links of the nationalist and anti-immigrant Radical Party or Unión Cívica with the sons of immigrants. See D. Rock, Politics in Argentina, 1890-1930 (London, 1975), pp. 49-50 and 63-4.

13 G. García, op.cit., p. 87.

14 D. Rock, op.cit., p. 22.

15 ibid., also see Appendix, page 238.

16 See page 145 of this thesis.

17 The narrator as a character in fiction is discussed by W. C. Booth, The Rhetoric of Fiction, under the sub-heading of 'Reliable Narrators as Dramatized Spokesmen for the Implied Author', pp. 211-24.

18 The works of Saldías and Grandmontagne have already been analyzed. Promisión, written by C. M. Ocantos in Paris in 1897, is an overidealized portrayal of a community of immigrants of many nationalities who live in harmony not only with each other but also with the local criollo population. The central message of the novel is that Argentina is a land of promise where the opportunity exists for everyone willing to work to become rich and successful. This idea, and the fairy-tale quality of the work, is succinctly expressed by the following extract:

¿Ves tú - decía la chiquilla. Aquí te acuestas mendigo y te despiertas ricachón, como en los cuentos; pero, no creas que va algún genio a ponértelo en la boca: te lo buscas tú antes y lo sudas. No más tarde que mañana por la mañanita que he de lucir yo unos diamantes, que ni los de la fideera.

See C. M. Ocantos, Promisión (Buenos Aires, 1914), p. 43.

Promisión was not included for special study in this thesis because it was not considered representative of the contemporary Argentine literary scene. Its author was a distinguished diplomat who lived most of his life out of his country, mainly in Spain, and his novels are imbued with a distinctly spanish flavour. Of him, Darío has said: 'Carlos María Ocantos escribe novelas absolutamente españolas cuyo argumento se desarrolla en Buenos Aires'. See R. A. Arrieta, Historia de la literatura argentina, op.cit., vol. III, p. 403.

19 G. García, op.cit., p. 25.

20 ibid., p. 39.

\section{PART THREE:}

\section{IV · "LIBRO EXTRAÑO"}

1 A. O. Blasi Brambilla, in Los Fundadores, op.cit., divides the work into the following sections: Libro extraño, Genaro, Don Manuel Palocbe, Mendez, and Hacia la justicia. L. Rusich, in El inmigrante italiano ..., op.cit. follows the same division. The Enciclopedia de la literatura argentina mentions six books in its entry on Libro extraño. R. Arrieta, in his article 'La prosa de 1852 a 1900', in Historia de la Literatura Argentina, III, p. 409, writes as follows: 'En 1894 publicó la primera parte de Libro extraño y sucesivamente Mendez, Don Manuel Paloche, Genaro, y Hacia la justicia'.

All references and quotations in the present study are taken from the undated 
Barcelona edition in which all the parts were published in two volumes by F. Granada y Cía. The index of this edition reads as follows:

$\begin{array}{lll}\text { Volumen I } & \begin{array}{l}\text { Libro primero } \\ \text { Libro segundo } \\ \text { Libro extraño: }\end{array} & \begin{array}{l}\text { Genaro } \\ \text { Don Manuel Paloche } \\ \text { Volumen II }\end{array} \\ & \text { Libro extraño: } & \text { Mendez } \\ & \text { Libro extraño: } & \text { Hacia la justicia }\end{array}$

2 L. Rusich, El inmigrante italiano ..., op. cit. pp. 168-9.

3 Names used in Argentina to define a swagger and a boaster.

4 See Appendix, pages 234-5.

5 This is the title of the last chapter of Don Manuel Paloche (pp. 131-6).

6 There is much evidence in Libro extraño of Sicardi's preoccupation with physical and mental health. All the key male figures such as Carlos Mendez, Enrique Valverde and Elbio Errécar, are doctors, and Paloche practices medicine although he fails to qualify.

7 There are no statistics available regarding individual nationalities living in Argentina in the nineteenth century, but, as a rough indication, the figures of the 1909 Census are given below:

Ethnic composition of the Federal District, 1909

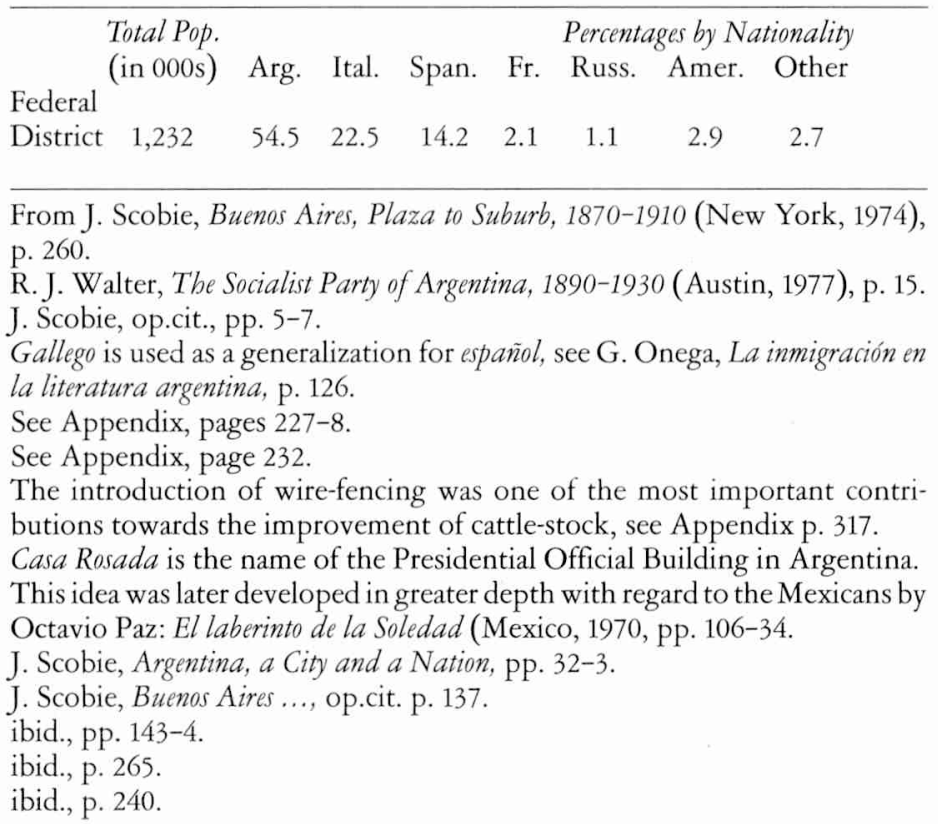


21 For the difficulties encountered in obtaining Sunday rest, see Scobie, ibid., 144.

22 G. Onega, La inmigración en la literatura argentina, p. 124.

23 ibid., p. 123.

24 A. O. Blasi Brambilla, op.cit., p. 97.

25 ibid., p. 100.

\section{CONCLUSION}

1 P. Macherey, Pour une théorie de la production littéraire (Paris, 1971), pp. 105-10.

2 D. Viñas, De Sarmiento a Cortázar, pp. 38-9.

3 See G. García, El inmigrante en la novela argentina, pp. 69-84.

$4 \mathrm{~J}$. Scobie, in Buenos Aires, ..., op.cit., states that it was extremely rare for first and second generation immigrants to penetrate the closed circle of the gente decente, see. pp. 216-18. and p. 226. 

APPENDIX 



\section{THE COLONIAL ERA}

From the time of the Conquest to the beginning of the eighteenth century, Castile's possessions in the Indies were concentrated mainly on two bustling centres of interest: one in Mexico and the other in Peru. The River Plate area was merely a small appendage of the Southern Viceroyalty, unimportant because of its lack of silver, awkward because of its wild and belligerent population and in any case not worth the trouble of conquest because of its out of the way position. In the Southern Hemisphere the centre of gravity was Lima, and it was towards this Viceregal city that the rest of the sub-continent turned, for Lima lay in the proximity of the vast mining areas of Alto Perú, and colonies were valued in relation to their ability to service the needs of the immensely important mining economy. All trade was supposed to be carried out via Lima, which explains why the area around the River Plate, troublesome and remote, was not considered worthy of Royal attention. ${ }^{1}$

There had, however, been several attempts in 1516,1526 , and $1535^{2}$ to found a settlement in Buenos Aires and discover an alternative means of access to Alto Perú, but each time the Spanish settlers were attacked by the Indians and forced to abandon their fort. The area fell into comparative neglect, while the Provinces of the Interior, that is, those that were within the radius of activity emanating from Alto Perú, prospered. They carried out an increasing amount of trade based on local produce and on the efforts of a thriving artisan industry. But with the decline in mining production in the second half of the eighteenth century, the Spanish Crown found its attention freed from the silver magnet of the Inca capital, and a gradual shift away from the dominance of Lima took place towards that area hitherto neglected by Spain, but whose potentialities had long been discovered by other European powers as a strategic centre of commerce. The River Plate water system had in fact not only been used as a convenient outlet for tax free bullion, but provided an ideal inlet point for cheaper non-Spanish manufactured goods. ${ }^{3}$

It was partly to curb, to legalize, and to tax this trade, and partly to stem the influx of foreigners who infiltrated her jealously guarded possessions that 
in 1776 the Spanish Crown created in Buenos Aires the seat of the Viceroyalty of the Río de la Plata. ${ }^{4}$ The city had by now greatly increased in population and wealth, and official recognition gave a fresh impetus to the area. Portuguese marauders were repelled, treaties and trade agreements were signed with the British, and the Crown sought to impart a greater measure of control by fostering the settling of Peninsulares in the area. The new mood is reflected in a letter sent by the Viceroy to the Spanish monarch: "This is our most important bastion in America whose development we must encourage by every means possible, for here we will win or lose South America'.

Although bullion was still important up to 1810 , a volte-face had taken place: the hitherto rich mining areas of Alto Perú became an ancillary part of this newly created Viceroyalty in which trade was the predominant source of interest. ${ }^{6}$ It is in this shift of direction that the origins of the predominance of the coastal region must be sought. It is from this change too that then stems the growing rivalry of interest between the Provinces of the Interior, whose prosperity had been allied to the hegemony of Lima, and the coastal provinces surrounding Buenos Aires, whose future lay with a completely different type of economy, one in which the interests of commerce took precedence even over production. The country became deeply divided and from then on the dominant sector would pursue policies which would widen the existing gap. Chief amongst these would be that of Immigration. It seemed important to underline the commercial basis of Argentina's history in view of the strong implication in some of the works studied that it was Immigration that introduced commercial practices and a materialistic orientation to the country.

\section{INDEPENDENCE AND THE STRUGGLE FOR UNITY}

The seeds of discord that were to cause basic disharmony and to polarize Argentina were nourished by the creation of the new Viceroyalty, a fact which it can be argued merely responded to the dynamics of history, but which, by encouraging porteño dominance, had so devastating an effect as to dominate all political activity for the following century, and beyond. Independence was merely another step in a direction already embarked upon, and its importance lay principally in an exchange of beneficiaries, but not in any basic alteration of social or economic policy. ${ }^{7}$

The aims of Independence were undoubtedly complex, but one of its major motivating impulses was the desire by the new creole porteño élite to 
achieve economic autonomy. Thus those areas whose interest coincided with colonial rule in Lima were far less enthusiastic about discarding the Spanish yoke, than were Buenos Aires and its surrounding provinces. The division which separated the two principal regions became acute on the very morrow of Independence. ${ }^{8}$ The Provinces of the Interior were eager to maintain the great deal of self-government that they had enjoyed under the rule of an Empire which was over-legalized and under-staffed; they were, furthermore, zealous to protect their old artisan industries and to hold on to an admittedly dwindling trade with neighbouring colonies. Thus, they clamoured for political autonomy and economic protection.? Opposing these interests stood those of the coastal provinces of the Littoral. These were at first dominated by the Port's economy which, as said, was based principally upon trade, but with the development of agricultural production and consequent rise in the importance of the estancia, a further division arose. This cut through the traditional division of the two political parties, the Federales and the Unitarios, as follows:

a) The Provinces of the Interior - where the old criollo élite, traditional, conservative, and Catholic, sought to escape political domination and economic competition from the coast. These were the Federales (although some of the most prominent members of the Unitario party such as Sarmiento and Alberdi came from the Interior).

b) The City of Buenos Aires - where an entrepreneurial clique of porteño businessmen and liberal intellectuals wished to open up the country to European trade and ideas. They saw the port with its privileged geographical position as the lifeline of the nation, and they sought to impose the hegemony of Buenos Aires upon the rest of the country. It was apparent to them that the interests of the Interior were outdated and moribund; they preferred to encourage the growing international trade that passed though their hands, and were prepared to share, albeit unequally, excise revenue with the rest of the country. Furthermore, they wished to increase and to improve its sparse population by planned policies of European immigration. These were the Unitarios.

c) The Provinces of the Littoral - third and last in this triangular struggle stood the landowners of the Littoral Provinces. Federales in name, their economic interests coincided to a large extent with the laissez-faire policies of the Unitarios. Their only quarrel with them was that the porteños intended to tax the land and proposed the greatest reduction in custom barriers, whereas the landowners saw their produce as the country's greatest source of income, and clamoured for its unhindered development behind protective trade barriers. ${ }^{10}$ 
Under the rule of their most famous champion, Rosas, their interests emerged triumphant, but dissatisfaction and dissention soon spread among the landowners themselves over the question of control of the port's revenues. The landowners of the Province of Buenos Aires, with Rosas as the richest among them, wished to take advantage of their Province's uniquely privileged position (the port of Buenos Aires could exercise virtually total control of international trade), and in this respect Federales to the utmost, they tried to keep the riches of their Province. The landowners from the Littoral Provinces, however, followed the Unitario line here, wishing for the federalization of the port and City of Buenos Aires, and the general sharing out of its income. In the end, it was one of their group, General Urquiza, who in 1852 brought Rosas down. The question of the federalization of the City of Buenos Aires as national capital, however, was not resolved until 1880, after a series of battles.

In conclusion, therefore, the whole period following Independence can be said to have been beset by conflict and the most bloody and cruel civil war: at first came the fierce struggles between the local caudillos whose anarchical character often belied strong factional interests; in the end the Interior was defeated and terrorized into submission by Rosas. Rosas was a nationalist in two senses: one, he closed Argentina's frontiers to European immigration and two, he fostered the cult of the gaucho whilst attacking the Europeanized manner of the ruling class. But as Sarmiento forecast in Facundo, his rule, which brought about the unification of the Provinces and the organization of the estancia, constituted the foundation upon which his opponents were able to build their programme of developing an agricultural economy by means of planned immigration.

\section{THE TRANSFORMATION OF ARGENTINA - THE YEARS OF PROSPERITY}

The second half of the nineteenth century in Argentina is often referred to as a period of transformation or even revolution, ${ }^{11}$ but it would be perhaps more accurate to view it as the culmination of a process that began over a century before, and which simply gathered momentum, with unprecedented vigour, in the period under discussion. The fact remains that from the 1860s onwards Argentina embarked upon a programme of evolution which caused sweeping changes. It did not, however, affect all areas equally; the new expansion could only be carried out at the expense of local 
industrial interests, which as has been seen, were located principally in the Interior. Thus, one region's gain was another's loss, and the Interior Provinces, who had emerged devastated and mutilated after the Wars of Independence and the anarchical struggles which followed, received the final coup de grace from the advances implemented by the new liberal regimes. Their voice will not often be heard in the years of easy porteño prosperity, a fact reflected in the literature of the period, which concerns itself very little with the forgotten provinces. It may be that today history can be seen to have repeated itself, and certain structural similarities appear between the adverse, if not ruinous effect of the overabundant wealth of the Indies' silver mines upon Spain's economic development and the superabundant fertility of the pampas upon Argentina's. But history cannot be judged anachronistically, and at that time the pressures for entering into the European orbit of international trade were not only logical but irresistible. The economic advantages which were offered by trading with Europe were linked directly to current philosophical thought, which believed that the only direction towards progress was that which faced unequivocally towards Europe. ${ }^{12}$ An examination of Positivist and Evolutionary ideas has no place in the present chapter, the point made was intended merely to offer a wider dimension for the cosmopolitan policies adopted at that time by Argentina's statesmen, and in which the desire to expand the economy was not seen separately from the necessity to 'populate the desert', to use Alberdi's time-worn phrase, ${ }^{13}$ and to improve the ethnic 'quality' of the population.

Argentina's so called transformation will be studied from the following angles:

1. The international situation, and Argentina's ability to respond to it.

2. The main developments related to the transformation of Argentina

(i) Immigration

(ii) Transportation

(iii) Agriculture.

\section{The International Situation and Argentina's Ability to Respond to It}

In an argument refuting the claim that Argentina's liberal statesmen acted in the interest of foreign powers, H. Ferns defends their policies and places them in an international historical context. He writes:

Argentina was, after the U.S.A. and Canada, among the first beneficiaries of a set of circumstances almost unique in human history, i.e. the existence of surpluses of wealth in a tiny part of the world, Western Europe, whose 
possessors and whose political authorities preferred to use it, or allow it to be used, outside their community for some purpose other than war, luxury or religion. ${ }^{14}$

The moment was ripe for an integrated economy both in the centre of the economic world, i.e. in the advanced industrialized countries of Western Europe and in some of the peripheral countries, including Argentina. ${ }^{15}$ In European countries large-scale industrial development caused certain relevant conditions:

(a) A waning interest in pursuing their own agricultural economy. This in time meant that foodstuffs would have to be imported, and that vast numbers of local peasant population were left unemployed and obvious candidates for emigration.

(b) An increased demand for raw materials for industry.

(c) A surplus of capital for investment in underdeveloped countries which were sufficiently stable to promise secure and high economic returns.

(d) An abundance of cheap manufactured goods in search for outside markets.

In Argentina conditions were propitious to meet these requirements:

(a) The vast prairies of the pampas and coastal regions were ideally suited for intensive agriculture. They could both supply the Europen foodmarket and absorb European surplus population.

(b) Argentina could intensify her output of traditional raw materials such as hides and tallow and diversify her production to include new demands such as rough wool for the carpet industry of Northern France and Belgium.

(c) Investment poured into Argentina as soon as the country was pacified and united until approximately 1910. This came chiefly from British capital, and a very special type of relationship developed between the two countries. ${ }^{16}$

2. The Main Developments Related to the 'Transformation of Argentina'

\section{(i) Immigration}

One of the earliest preoccupations of the Government which took office after the defeat of Rosas was to increase the country's very small population by a programme of large-scale immigration, which was obviously a fundamental requisite for any possibility of expansion. In a combination of forces and circumstances which worked jointly towards the expansion 
of the Argentine economy, no one factor can be regarded as dominant, but it is still valid to point out that every development relating to the transformation of Argentina was directly and intimately linked with immigration. In view of the specialized nature of this thesis, it has been thought fitting to deal in greater detail with immigration, devoting a separate section to it.

\section{(ii) Transportation}

Changes in the system of transportation occurred both inside and outside the country. The most important change inside Argentina was the replacement in certain parts of the slow, expensive yet flexible carreta by the modern railway. Its significance in the development of the areas through which it ran cannot be overestimated, for it provided virtually a direct link with the markets of Europe. ${ }^{17}$ It brought the population and equipment to exploit the land and offered a quick, cheap means of transporting local produce to the main port. It increased the value of land many times over. The railways had an added effect in that they strengthened the hegemony of Buenos Aires over the rest of the country. They were built upon a fan system which led inevitably towards the port and inter-regional communication which did not coincide with their routes was neglected. Their presence was felt in the Interior as they brought cheap manufactured goods further inland, thus breaking the last protection enjoyed by artisan industries: distance.

Outside the boundaries of the country Argentina was affected by advances in steamship navigation, which speeded up sea travel and reduced the cost of international trade and migration. The invention of large scale refrigerators for ships on board meant that meat did not have to be unpalatably salted for export but could be either chilled or frozen.

(iii) Agriculture $^{18}$

The changes that occurred in the country's method of agriculture were basic, affecting both life on the pampas and prosperity in the city. The principal changes occurred in the following spheres:
(a) Cattle raising
(b) Sheep raising
(c) Crop agriculture

\section{(a) Cattle raising}

Until the beginning of the expansion of agriculture, land in the fertile pampas had been left largely unexplored, and the Creole, like the Spaniard before him, acquired land for social prestige but took little interest in it, 
preferring to live in the city. The existing free roaming cattle was scraggy, its meat stringy and unappetizing. It was spurned even by the plantation slaves of Brazil and of the Caribbean and was raised principally to provide hides and tallow. But increased demands in European markets for meat, however, made the country realize its future potential, if it could improve the quality of its produce. It was decided to import Shorthorn and Angus bulls from Britain in order to up-grade the quality of the local breeds and produce a more acceptable type of meat. The new breeds had to be protected and this was one of the reasons for the introduction of wire fencing, a step deeply resented by the criollo rural population. It meant the end of free roaming for cattle and gauchos alike, and brought with it unwelcome change in working conditions. It is a curious stroke of chance that it was the experiments with cattle breeding that Darwin witnessed in Patagonia which inspired him to formulate some of the ideas of his Evolutionary thesis, which in turn became an influential factor in Argentina's policy for encouraging European immigration. ${ }^{19}$

\section{(b) Sheep raising}

Around the middle of the nineteenth century the coast's economy turned increasingly towards sheep raising in order to meet the apparently inexhaustible demands for their tallow and coarse wool. By the 1880 s wool contributed between $50 \%$ and $60 \%$ of the value of Argentina's exports. As with cattle, imports of higher breeds improved the native stock, and more and more land was devoted to sheep raising. Because it was a relatively more sedentary occupation than cattle ranching, it was spurned by the local population and sheep farming was largely carried out by immigrants. These were Irish and Basque. A further significant consequence of sheep raising was the pressure upon territory, which led to the successful military campaign against the Indians. Furthermore, sheep also attracted foreign investment in land, in railroads and in packing plants.

\section{(c) Crop farming}

Many of the changes implemented by the thriving sheep economy paved the way for the introduction of crop farming. This had hitherto been neglected by absent landlords because it necessitated investment in labour and equipment, and was in any case shunned by local gauchos as an inferior and unmanly occupation. But foreign capital, the greater expanse of land available, the cultivated areas which grew up side by side with the railways, coinciding with great demand for cereal in Europe led to a spectacular expansion of crop agriculture. But not all the production was used for 
export; local consumption grew from the days when bread was almost unknown on the pampas and also a higher quality grain, known as alfalfa, had to be grown to feed the new cattle breeds. Crop agriculture, therefore, became not only the country's principal export commodity, but also its main activity: this was carried out predominantly by immigrant labour, and the one could not exist without the other. 


\section{POLICY AND DEMOGRAPHIC CHANGES}

During the nineteenth century began a cycle of great migration from Europe: between 1830 and 1957, sixty-five million people left the continent. Of these $61.4 \%$ went to the U.S.A., $11.5 \%$ to Canada and $10.1 \%$ to Argentina. From North West Europe came $50.4 \%$ of the total figure, and $35 \%$ from the South West. Argentina did not enter into this migratory movement until the last third of the century, by which time the flow had moved to stem predominantly from South Europe, as can be seen from the following statistics:

\begin{tabular}{clc} 
Years & \multicolumn{1}{c}{ Origin } & Percentage \\
$1846-1850$ & N.W. Europe & 99 \\
& S.W. Europe & 1 \\
$1881-1890$ & N.W. Europe & 51 \\
& S.W. Europe & 48 \\
$1891-1900$ & N.W. Europe & 37.2 \\
& S.W. Europe & $72.8^{1}$
\end{tabular}

The last figure quoted includes the peak years of immigration to Argentina. The fact is significant in determining the ethnic and cultural background of immigration. According to G. Germani, $80 \%$ of immigration to Argentina was of Latin origin; roughly $50 \%$ came from Italy, and $30 \%$ from Spain. The remaining 20\% was made up of Poles, Russians, French, and Germans. British immigration was negligible in numbers. ${ }^{2}$ But the immigrants formed a far less homogeneous society than these figures would suggest, for both Italy and Spain were countries whose unifaction was only skin deep, and who elicited local rather than national allegiance. Thus, their people were divided by sectional loyalties as well as by dialect differences, and failed to form a strong cohesive group in their new environment. Nor did they find a strongly affirmed homogeneous society in Argentina.

Most of the immigrants who came to Argentina settled in the Littoral. This had been an area of immigration from the very earliest days, for even at the time of colonization the indigenous population consisted of divided 
and hostile primitive nomadic tribes who, unlike the concentrated and more highly developed populations of Mexico and Peru, were not easily to be absorbed and organized for colonial exploitation. ${ }^{3}$ Thus, the early settlers found they had to import an immigrant labour force which consisted largely of negro slaves. According to J. Lynch, the negroes formed the basis of miscegenation of as much as $32 \%$ of the population, ${ }^{4}$ which became divided into a subtly graded caste system: sixteen different castes are recorded. ${ }^{5}$

Immigration had been warmly encouraged immediately after Independence but the country was still in too great a turmoil to cope successfully with an expansion programme. Thus, Rivadavia's liberal plans would have to wait until sectional differences were burnt out and until the country was sufficiently stable to attract foreign investment and immigration. It was mostly his ideas, however, which were written into the 1853 Constitution and which formed the theoretical basis for planned immigration. ${ }^{6}$

The Constitution guaranteed unlimited entry to all foreigners who wished to come to work in Argentina; it professed freedom of worship, and it gave foreigners the same civil rights as Argentines, without incurring the obligation of citizenship and with the free option of becoming naturalized after a stay of two years. It was closely inspired by the U.S.A. Constitution of 1787, whose liberality it surpasses with respect to the rights granted to immigrants: it includes their welfare as one of its fundamental aims: '... Asegurar los beneficios de la libertad para nosotros, para nuestra posteridad y para todos los hombres del mundo que quieran habitar el suelo Argentino'?

The Ley de Inmigración y colonización, known as Ley Avellaneda, which was decreed on 6 October 1876, set out in more specific datail the role of the Government with regards to Immigration Policy. ${ }^{8}$ A special Department was to be formed to foster desirable immigration, to check and control conditions of travel, and to direct the flow of immigration within the country. The law also defines an immigrant as any person of good morals under sixty years old, who arrives with a second or third class passage as casual labour, artisan, industrial worker, farmer, or teacher.

Immigrants were to be protected in their contracts of employment and the Law further specified that they were to be housed and fed for the first five days, and were to be given every assistance in finding a job to their satisfaction. They were to be transported to their place of work inside the country at Government expense. Provision was made in certain cases for the Government to pay for the total costs of the journey from abroad.

Finally, there was to be an Oficina de Tierras y Colonias to advise on the sale 
and exploitation of the land. ' The vital place allocated to immigration by the Government can be judged from the following official message delivered by Avellaneda and Simón de Irondo:

Están todos felizmente convencidos en la República de que su prosperidad y porvenir dependen de dar una solución al problema de la inmigración espontánea y es por esto que le preocupa tanto a los hombres de la Nación misma, como a sus poderes públicos. ${ }^{10}$

But these were hollow words, which found very little backing in the reality of the crowded, insanitary travelling conditions, disorganization upon arrival and, in most cases, total lack of accommodation and equipment for work. Once the immigrants arrived at their final destination, there was no protection in the contracts of employment. ${ }^{11}$ The flow of immigration continued to be empirical, guided by economic factors rather than Government policy; yet this did not in any way stem its ever increasing tide.

The arrival of large-scale immigration caused dramatic demographic changes in Argentina. From 1889 onwards, there was a spectacular increase in the country's population, as can be seen from the following figures:

Table I

The Argentine Population: $1869-1943^{12}$

Years

1869 (I Census)

1895 (II Census)

1914 (III Census)
Population

$1,737,076$

$3,954,911$

$7,885,237$
Average yearly increase per 1.000 inbabitants

The proportion in which this was due to immigration can be ascertained from the following figures: ${ }^{13}$

Table II

The Foreign Population: 1869-1914

\begin{tabular}{|c|c|c|c|}
\hline Years & Foreigners & $\begin{array}{c}\text { Foreigners } \\
\text { per } 100 \\
\text { inbabitants }\end{array}$ & $\begin{array}{c}\text { Foreigners } \\
\text { per } 100 \\
\text { native } \\
\text { Argentines }\end{array}$ \\
\hline
\end{tabular}

$\begin{array}{lrrr}1869 \text { (Census) } & 210,300 & 12.1 & 13.8 \\ 1895 \text { (Census) } & 1,004,500 & 25.4 & 34.0 \\ 1914 \text { (Census) } & 2,358,000 & 29.9 & 42.7\end{array}$


Immigration, however, was not evenly distributed throughout the country. It has been observed repeatedly that immigration was encouraged in the interest of porteño economy and its dissemination reflects this fact, furthering the imbalance between the Interior and the Littoral.

Gino Germani illustrates this succinctly in the following table: ${ }^{14}$

Table III

Foreigners Living in Three Areas of the Country,
per 100 Foreigners, 1869-1914

Córdoba

Pcia. Bs.Aires

Years

Buenos Aires

Entre Ríos

Mendoza

Sta.Fa, Pampa

1869

48

39

42

52

1914

41

49

\section{Rest of \\ the country}

10

9

10

Immigration was not only a coastal phenomenon, but became increasingly an urban one. While part of the original plan had been to foment the population of the desert, this is something that, for reasons to be examined shortly, was carried out only partially and inefficiently.

Dissatisfaction and lack of opportunity drew the immigrants to the cities, and the greatest proportion of them settled in the littoral urban centres, particularly Buenos Aires. Approximately 50\% of the growth of the capital between 1869-1914 was due to the increase in its foreign population, a pattern which is reflected in other cities. ${ }^{15}$

Not every immigrant who came to Argentina settled there permanently. From 1890 there was a considerable movement to and from the Atlantic of seasonal labourers, aptly called golondrinas, who came for the summer harvest. Furthermore, there were those who failed to settle in the new surroundings and returned to their country of origin. Any major financial crisis was immediately parallelled by a movement of emigration. ${ }^{16}$

One third of the total proportion of the population was foreign born, the highest percentage in any country in the world, ${ }^{17}$ and in some areas the percentage was significantly higher. It is estimated that in Buenos Aires in 1914 , three out of every four members of the active population were foreign born. These proportions could not fail to have a deep rooted and lasting impact upon the nation's cultural ethos, one which surpassed by far the dreams and desires of the original advocators of large-scale immigration, such as were Sarmiento and Alberdi. 


\section{ECONOMIC, SOCIAL, AND POLITICAL CHANGES}

There are in Alsina's book, La inmigración en el primersiglo de independencia, a series of diagrams which illustrate the close links that existed between immigration and economic growth, comparing figures of immigration with rises in production, exports, and imports. These links correspond too with the parallels observed between immigration and the expansion of the Littoral Provinces of Argentina. ${ }^{18}$ The three areas into which the country was divided were each affected differently and will be dealt with separately following the divisions established in Section I.

\section{The Provinces of the Interior}

In keeping with the general historical process which determined a shift in the centre of gravity away from this region, the Interior was the area least affected by direct immigration. ${ }^{19}$ Its interest depended heavily upon protected internal expansion and, therefore ran contrary to the basic tenets of the economic policy of which immigration formed an integral part.

As seen above the railway removed the protective barriers of distance. However, it did not serve only to flood the market with cheap imports; it also provided a means of encouraging the expansion of certain agricultural products in the Interior with a view to export and domestic consumption in the littoral. Thus, Salta and Tucumán were able to exploit commercially an existing sugar production, but this was manned chiefly by seasonal Indian and mestizo labour who worked under quasi-slave conditions, and attracted few immigrants.

In Mendoza, however, the expansion of the wine industry depended upon work all year round and, therefore, was of greater attraction to immigrant labour. Furthermore, there existed the possibility of ownership of small vineyards. The immigrant population rosa from $0.5 \%$ in 1869 to $23 \%$ in 1914 , the largest population in the Interior. ${ }^{20}$ The real influence of immigration, however, lay not in its direct impact but in the fact that it helped to build up and strengthen the hegemony of the littoral, thus completing the dependence of the Provinces of the Interior upon porteño policies.

\section{The Provinces of the Littoral}

The demographic changes that took place in this part of the country were intimately linked with Argentina's economic development. This was based upon an international system of free trade, and owed its immediate 
success to the agricultural output of the Provinces of the Littoral. The importance of immigration in the exploitation of the country's agricultural resources has already been suggested in connection with the transformation of the face of the pampas. The role of the immigrant, however, was to consolidate, rather than to change, the country's basic economic structure which increasingly depended upon agricultural output. The value of land multiplied manifold, but there was no general share out in its ownership. A land tenure system based on latifundia was encouraged, and large-scale estancias became an economic necessity. Taxes were the same for large and small estates. Thus the economy was working in favour of the small land-owning élite; a system of extreme economic polarization was perpetuated to the detriment of the immigrant peasant workers, and of the local gauchos.

The situation was not uniform throughout. In the provincesof Santa Fe and Entre Ríos, cheap land was still available around 1870, and there existed possibilities for the industrious peasant to acquire a small or medium sized farm, either on an individual basis or as a member of a larger agricultural colony. These were originally set up on land bordering the newly established railways, and they depended chiefly upon crop-farming.

In a study related to the Province of Santa Fe, E. Gallo affirms that in these areas immigrants took an active part in institutional life. They were in charge of protecting their colonies from delinquent transients, and from marauding Indians, and the colonies who had their own institutions were completely autonomous until approximately 1880. Immigrants were often to be found as jueces de paz and as land-valuers for tax purposes, and, in the southern part of Santa Fe in which there was a predominantly immigrant population, there was a greater involvement in elections than in the rest of the province. This direct participation, however, was limited to the municipal level, and their influence was felt only very remotely at provincial or national levels. ${ }^{21}$

In the Province of Buenos Aires the situation was completely different, for land had been more valuable from the outset, and was, therefore, almost impossible for the penniless newcomer to acquire. He had to be content with becoming a share-cropper, or a tenant farmer, a solution which benefitted first and foremost the estanciero, but which held certain attraction for the immigrant too. The estanciero benefitted because with crop-farming he diversified the production of his estate. Land which had hitherto lain fallow was exploited through a system in which the land-owner had little or no investment to make, yet was assured of the benefits of any increase in the value of the land. 
The immigrant farmer had two possibilities open to him: he could become a share-cropper or he could become a tenant farmer. As a share-cropper, he received implements, seed and advances of food from the land-owner and turned over half his harvest in payment. He could stay for only one or two years, but he had made no investment, and stood a chance to save enough money to become a tenant farmer. As such his conditions of contract were somewhat different, for the onus was upon the tenant to provide for all the equipment and to make the necessary investment for crop-farming. ${ }^{22}$ There was yet a third possibility for immigrants to work on the land in the Province of Buenos Aires, and that was as seasonal labourers. From the 1890s about 50,000 Italian and Spanish golondrinas, or migrant harvesters, came to Argentina for the summer months and then returned home. Wages were such that they could pay for their fares after a fortnight's work, the rest constituting a high net profit.

And yet the assertion can be made that all three categories shared this golondrina quality, for ultimately they all worked under transient conditions, with an eye to move on either to the City or back to their homeland. This was the result of the Government's failure to devise and implement a proper homestead policy which would have afforded the immigrant the possibility of sinking economic, as well as psychological roots into the land they wished him to populate. ${ }^{23}$ Therefore, in spite of dramatic changes in productivity, the basic economic structure and policies were not altered to suit new conditions and the immigrants were left unintegrated in a land tenure system which ran on the same feudal lines as before. The same conditions suffered by the immigrants applied of course, to the native population, but the links which had bound the criollo to the land and to his master were different from those that held the immigrant. The criollo activity on the land was confined principally to the care of cattle. While the new economy brought in changes such as wirefencing, which would inevitably limit the gauchos' possibilities of free-roaming, his work still depended upon his personal ability, and upon his own qualities of horsemanship and courage. Cortés Conde comments that his dependence on the estancier 0 was ruled by feelings of loyalty and personal admiration and not material gain. The gaucho, in fact, scorned the immigrant motivation of economic reward, a work ethos which he despised. So, while the criollo was culturally integrated into this type of society, for the immigrant, who in many cases came from a non-rural background, it was often only a temporary stop on his march to the cities.

As a consequence of all this, immigrants failed to evolve a strong civic conscience in the sense that very few wished to become naturalized and take an 
active part in the political life around them. Nor was there any great encouragement or incentive for them to do so, and the immigrants continued to look towards their own consulates for protection and guidance and remained largely unassimilated, as the following table illustrates:

\section{Table IV}

Naturalized Foreigners per 100 Foreigners Resident in each Area, 1895-1914 ${ }^{24}$

$\begin{array}{ccc}\text { Area } & 1895 & 1914 \\ \text { City of Buenos Aires } & 0.2 & 2.3 \\ \text { Rest of the country } & 0.1 & 0.9\end{array}$

These figures are not unrelated to the general politics adopted towards immigrants: that of exacting the best use out of them, without giving anything in return. It is not surprising that many responded in kind by trying to obtain as much material gain from the system as possible, and yet remain separate and aloof from its political life.

\section{The City of Buenos Aires}

Althoug immigration was directed primarily to the deserted rural areas of the country in accordance with the Alberdian doctrine of poblar el desierto, it was to the growing urban centres that most of it found its way. The reasons for this are complex, but are due primarily to the fact that opportunities for owning land were so extremely difficult and also because agricultural development became less and less a labour intensive occupation. Thus, immigration to the cities stemmed from two sources: those who came directly from Europe, and those who came, dissatisfied and disillusioned, via the rural areas. ${ }^{25}$

The City of Buenos Aires can be taken as the model of urban expansion, since its development is representative of changes which occurred in other important coastal cities on a smaller scale.

\section{A. Economic changes: Industry and Commerce}

A corollary to the gigantic expansion of the country's agricultural output was the stunting, by lack of incentive and of Government planning, of its industrial growth. ${ }^{26}$ The laissez-faire policies which had greatly undermined the old artisan industries of the Interior had a similar effect on the newly emerging industries of the Littoral. 
In his paper on 'Problemas del crecimiento industrial', Cortés Conde writes that industrial output in Argentina increased four-fold between 1855 and 1895 , yet he is quick to point out the relative merit of this statement by saying that before this date industry was almost non-existent. ${ }^{27}$ Yet even this limited original increase was not maintained because of lack of investment and of interest in developing this sector of the economy. The tax system was such that it favoured cheap imports, but penalized the import of capital equipment. Such industrial development as there was, was concerned mainly with the servicing and processing of agricultural production. It did not extend to the manufacturing of import subsitution goods in order to supply the demands of an increasing domestic market.

Although the country continued to depend upon its agricultural exports, there was sufficient industrial activity for the coastal cities to expand greatly. In this the immigrants played a predominant role. Scobie writes:

In the coastal cities of the 1880s - whether among Buenos Aires' 300,000 inhabitants, the 40,000 of a rapidly growing Rosario, the 15,000 located in those two principal capitals of Santa Fe and Paraná, or San Nicolás's 10,000 immigrants formed the basis for a far greater metamorphosis than occurring on the Pampas. ${ }^{28}$

The principal sectors in which immigrants found employment were:

(a) In the handling and processing of agricultural produce in tanneries, flour mills and wool cleaning plants, and in the new frigorificos.

(b) In the railways, where foreign labour was given preference over the criollos. ${ }^{29}$

(c) In the construction industry thousands of immigrants were employed in the building of a new port not only in Buenos Aires but also in La Plata, in Rosario, and in Bahía Blanca. Furthermore, the high profits of the years of easy prosperity were invested to a large extent in the aggrandizement and embellishment of the new national capital. In the 1860 s Buenos Aires was still a village, la gran aldea, but within a few years it grew vertiginously to become the leading city in South America. In addition to luxury building there were more modest buildings to be erected in order to house the masses that were converging upon the cities. In this way immigrants not only carried out work, but also created it.

(d) In small industries. Although a very high proportion of manufactured goods was imported from Europe, a fact exacerbated by the immigrants' preference for articles that were familiar to them ${ }^{30}$ there was, nevertheless, an increasing activity in small-scale local industries, producing things such as textiles, shoes, macaroni, beer, etc. 
(e) In service industries; although it was the native population rather than the immigrants who were employed here, immigrants also found occupation in commerce, in which the possibilities of success were helped by the increased markets which they themselves constituted, and by the traditional distaste in which trade was held by the criollo population. ${ }^{31}$ However, the gigantic upsurge in the country's commercial activity lacked the backing of sound economic policies, and was of a highly speculative nature. Profits from both agriculture and from industry were being used for financially speculative enterprises, instead of being ploughed back into production, and during the late 1880s Argentina was importing more than she was exporting, on the strength of increasing loans issued in the London capital market. ${ }^{32}$ The situation was bound to become explosive, and in 1890-1891, a crisis developed generally referred to as the Baring Crisis, in which the shares market collapsed completely, bringing ruin to many of its shareholders. The operation was intimately linked to international high finance and to an internal situation of political corruption well beyond the control of the immigrants engaged in commerce, who had only recently settled in Argentina, but so far as they created and manipulated the bulk of commercial activity, they must be seen as accomplices in unsound commercial activities. The collapse of the shares market became the cause and the excuse of violent overt xenophobia. However, the country recovered from a protracted slump and the peak years of Argentina's prosperity were still to come after the turn of the century.

The immigrants who transformed the face of the pampas, also changed and gave impetus to the cities, but their influence remained superficial. Just as they had been unable to break the basic land tenure system, so were they powerless to alter economic policies to favour industrial and commercial interests in the city.

\section{B. Social and Political Changes}

It is clear that so massive an influx of people as that which came to Argentina from 1880 onwards would have a deep effect upon the social composition of the country. In the pre-immigration days Argentine society was divided on traditionally feudal lines: there was a small, but powerful élite, la gente decente, and the rest, la gente de pueblo. ${ }^{33}$ One of the concomitant effects of the policy of expansion, however, was the creation of new sectors of society, such as the urban proletariat, and the rising middleclasses. 


\section{(i) The upper-classes}

The immigrants played but a small role in upper-class society. According to G. Germani this group constituted an all-powerful $0.7 \%$ of the total active population of which more than $40 \%$ belonged to the great landowning bourgeoisie, which was traditionally closed to immigrants. ${ }^{34} \mathrm{~A}$ further high percentage of members of the upper-classes was formed by professional men, whose ranks had not at first been open to any but the most eminent foreigners. Only $17 \%$ was formed by the wealthy industrialists, but many of these were members of the landed oligarchy who had re-invested their profits in industry. Thus, while the bulk of the country's industry and commerce owed its development to immigrant labour, the highest positions of power were still reserved for the criollo élite. In his study on La clase alta, José Luis de Imaz reflects on the paucity of immigrant surnames among those included in this group and points to its generally closed nature. ${ }^{35}$ Few immigrants managed to penetrate into the exclusive circle of the criollo aristocracy, but its prestige, supported by the country's unchanging power structure, was such that those immigrants who could have formed a cohesive group of opposition failed to do so preferring instead to imitate and adopt élite modes of conduct.

Yet even if the upper-classes did not suffer from direct penetration of immigrants, they were still affected indirectly, since the leaders of society were the first and greatest beneficiaries of the country's economic expansion. One example of this would be the dramatic increases in the value of land. With the policy of expansion the traditional polarization of a twotiered society became diversified into a complex and dynamic hierarchy. This had the ultimate effect of making the aristocracy conscious of their position of power and unquestionable privilege. Faced with the emergence of an immigrant society, the aristocracy not only closed their ranks, but became more firmly persuaded of their right to assume a role of leadership as the true sons of Argentina, and masters of its soil. ${ }^{36}$ They continued in government unchallenged until 1916, and their economic interests were safe-guarded even by the popular governments which followed.

\section{(ii) The urban proletariat}

It has been stated that whereas it was the advanced industrialized nations of Northern Europe who sent their surplus capital as investment to the under-developed countries of the economic periphery, it was the poorer countries of South-West Europe who sent their surplus peasant popu- 
lation. ${ }^{37}$ In Argentina, this had been placed predominantly in the rural sectors of the Littoral, but within a few years large numbers made their way to the city centres. After 1890 new arrivals tended to stay directly in the urban areas, where they helped to swell the population of the urban proletariat. In his article on 'Machine Politics in Buenos Aires and the Argentine Radical Party', D. Rock remarks that in 1912 three-quarters of male immigrants in Buenos Aires were working class. ${ }^{38}$ It is safe to estimate that in earlier years the proportion of working class immigrants in the city would have been even greater. At first life in the city was indeed one of penury and deprivation: their living conditions were often appalling in over-crowded, unhygienic, dismal conventillos. ${ }^{39}$ Nor were working conditions any better, with long hours, few civil rights and increasing expenses to be met out of decreasing pay-packets. ${ }^{40}$

There were, however, still ample opportunities for those who stayed, and who were capable and willing to work assiduously to amass a small capital and rise socially, either to the top rung of the working clases or in some cases into the emerging middle-classes. The bulk of the immigrants who arrived in Argentina were spurred by motivations of 'making good' and then returning home. Their materialistic work ethos became an almost insurmountable stumbling block between foreign and criollo workers. According to J. Vazeilles, it is, if anything, utopian to see any solidarity between el peón criollo and el obrero inmigrante. ${ }^{41}$ This led to a lack of solidarity both in social and political terms. Socially the divisiveness is often explained in moral terms as relating to cultural values. Thus, Romero writes about 'la masa criolla que vivía a su guisa, con pobreza pero sin miseria y gozando la plenitud de sus exigencias espirituales'. The immigrant, according to this writer, had no such spiritual demands made upon him. His psychology was simply 'caracterizada por la sobrestimación del éxito económico,. ${ }^{42}$ The argument may be put forward at a more objective level in that the immigrants who had already shown a measure of ambition by leaving their homeland were, in fact, more ardently motivated and did not have emotional ties with the traditional way of life. They began to be seen as a money-grabbing, materialistic work force who were menacing the existing population with unwelcome change.

Germani's figures show that they were the ones to seek employment in productive industries and in commerce, whereas the criollo population felt more attracted towards tertiary activities of bureaucratic or economically non-productive employment. ${ }^{43}$ The conclusion might be drawn that the criollos, working for the system, would be anxious to perpetuate the status quo, but that the immigrants would be more highly motivated towards 
effecting an active change in the country's economic policy, seeking some greater measure of protection for its nascent industries, yet such political dynamism did not take place to any serious extent.

In political terms, the immigrant urban proletariat is accused on two opposing fronts: the one being their apoliticism, caring nothing for the interest of the country which had welcomed them, being selfishly geared towards their own economic and social betterment, and the other accusing them of bringing with them and spreading unwelcome political ideas of socialism and anarcho-syndicalism. There is some measure of truth in both charges: a large majority of the immigrants who came did so out of economic considerations, which left them little leisure to become politically involved, particularly in matters which they had little hope of influencing. ${ }^{44}$ They kept for many years a transient mentality, and found little encouragement on the part of the existing system to become integrated into the political life of the country. The number of immigrants who became naturalized was exceedingly low and remained so even after the Sáenz Peña Law was passed in 1912, which gave naturalized male adults the right to vote.

The situation was the complete reversal of events in the U.S.A., where political agents went to the boats to welcome and try and influence the future voter. In Argentina out of the four main political parties, i.e. Unión Cívica Radica, Partido Demócrata Progresista, Partido Conservador, and Partido Socialista, only the latter showed any interest in incorporating the immigrant vote into the system. The power base of the Socialist Party rested upon a part of the intellectuals and with the aristocracy among the urban proletariat which included a high percentage of immigrants, but left aside all the rural immigration, as well as that rising sector of immigrant society which had social aspirations and identified with the middle-classes. The ideology of the Socialist Party coincided with immigrants' interests in its cosmopolitan character. A complex example of this attitude is to be found in its economic policy, which far from being protectionist to help the industrial proletariat by building up home industries, followed the short term view of supporting free trade, in order to keep prices low for workers. Its founder and leader, Juan B. Justo, was an ardent free-trader throughout his political career.

There was yet another movement on the Left of the political spectrum in which the immigrants did play a predominant role, and that was anarchosyndicalism. In capitalist Europe there was a growing force of discontent on the part of the urban proletariat which had great influence in Spain and in Italy and in Eastern Europe. Repression in these countries was severe 
and many an immigrant to Argentina was a political refugee. The movement was violent and international. ${ }^{45}$ Its origin in Argentina can be traced as far back as 1874, when there came into existence a number of sections of the International Working Men's Association, but as Germani points out they constitute protest movements not as nationals, but as foreigners. ${ }^{46}$ From 1890 onwards socialism and anarcho-syndicalism became an influential, militant force, aiming particularly towards the strengthening of trade unions. By 1896 there existed in Buenos Aires alone thirty unions and twenty-six strikes had taken place. The anarchists believed in the efficacy of direct action and provoked wave after wave of strikes, against employers and against the high cost of living. There was an additional political angle directed at a corrupt and autocratic dictatorial government who responded with progressively greater repression. A state of siege was declared five times within eight years: there were mass arrests and the union's headquarters were raided and closed.

These developments affected the lives of the immigrants most intimately for they formed nearly all the leaders of the unions and constituted the vast majority of the rank and file. They resulted in the unleashing of latent feelings of xenophobia among the criollo population, which saw itself threatened by hosts of foreigners. Thus there was at the turn of the century a swing in the ideological climate in Argentina towards strong feelings of nationalism. The political consequences resulted in the passing of the first restrictive measures against foreigners which became increasingly repressive over the next two decades.

Anarcho-syndicalism, however, ought not to be over-estimated. It formed a strong protest movement which the Government could not afford to neglect and caused frequent disruptions in Argentina's industrial life. But the anarchists, confined as they were to an organized urban industrial proletariat in a country in which industry was only just emerging from the artisan stage, did not have a sufficiently strong or influential power base to cause any fundamental changes. Their violence resulted, if anything, in alienating public opinion and creating fear and hatred among the middleclasses as well as the oligarchy. ${ }^{47}$ The small improvements that were achieved in social legislation survived, for the time being, in print only. Nor did they effect any changes in economic policies, which remained largely unaltered until 1930 .

Therefore, the only result of the movement was to create a negative effect on the immigrants, who became subject to stricter legislation, and lost their previously undisputed right of residence in the country. Further, those who had been vociferous in their acclamations in favour of immi- 
gration became suddenly aware of a new unforeseen danger to their traditional way of life and hegemony.

\section{(iii) (a) The middle-class}

Argentina was one of the first countries in Latin America to break with the traditional structure of society, and to form a sizeable middle-class. This phenomenon was intimately linked with the explosive economic expansion in which immigration played so vital a role. By 1914, the middleclasses formed one third of the total population, and lived predominantly in the urban centres of the Littoral. ${ }^{48}$ It has already been noted that these were the areas of greatest immigration.

The immigrant content of the middle-class can be divided into two unequal groups: those who belonged to it from the outset, and those who joined it. The number of immigrants from the middle-classes who arrived in Argentina was very small. There are no accurate statistics, but the following information may be used as a rough guide. According to declarations made on entry, between 1890 and 1909 only 4\% of immigrants stated their occupation as comerciantes and only $4 \%$ as professional men. ${ }^{49}$ The figures, however, may not include first class travellers.

But Argentina was a country of easy upward mobility to all but the very highest echelons of society, an opportunity of which immigrants took full advantage. It has been noted that in rural areas the land tenure system was such that only the very few could become small holders or reasonably secure tenant farmers, thus, the formation of an immigrant middle-class in these areas was rendered difficult. But an indirect effect of this rigidly closed land system was migration towards urban centres, where possibilities for economic and social improvement were greater. Thus, although immigration did not participate directly to any great extent in the economic bonanza from the land, they did so indirectly via the growth of the city centres, the emergence of industry and the subsequent transformation of the social structure.

The largest sector in which immigrants found possibilities of rising was commerce and industry. ${ }^{50}$ The ElDorado, so rarely to be found in the exuberantly rich soil of the pampas, was a greatly more realizable dream in the city. In his book Buenos Aires, from Plaza to Suburb, Scobie maps out the often slow and painful progress of immigrants from pestilential conventillo to ever expanding house, and from humble employee to boss. ${ }^{51}$ In a study comparing the assimilation of working class and middle-class immigrants, Francis Korn asserts that the former adapted more rapidly to the criollo way 
of life, and integrated better into their strata of society than did the latter, who retained their values of material advancement. ${ }^{52}$

It has been noted repeatedly that the immigrants in Argentina remained largely apolitical, yet within the context of this assertion their leading role in working class political protest movements had been delineated. There was no such action among the middle-classes, among whom the industrial entrepreneurs were numerous and had particular reason for protest. They were poorly served by successive governments, who remained constant throughout the period under discussion (1880-1930) and beyond, with respect to one factor: their economic policy. Yet there was no overt, direct pressure put upon the Government by the immigrant-entrepreneurial class to alter a policy which had long been abandoned or modified by the nucleus countries which had been its original exponent. ${ }^{53}$ The reasons for this are complex, and most have been mentioned in connection with alternative problems, but for clarity's sake will be repeated here:

(a) The unaltered power of the land-owning élite which, in fact, had increased under the present economic policy. This ensured that land interests would continue to be served by the government in office.

(b) Lack of cohesion among the middle-classes. This was due to the recent emergence of the class as a whole, and to its heterogeneous composition and diverging interests. Only those connected with manufacturing industries were affected, but by virtue of the importance of their output, particularly during the years of enforced home production of the First World War, they could have been expected to from an influential pressure group. (c) The immigrants' economic motivation and general apolitical attitude summarized by Di Tella as 'el clásico "no te metás". 54

(d) The fact that there were no adequate channels of communication between immigrant industrialists and the political parties. Of these, the Conservatives would continue to support liberal policies in the interests of their class. The Socialists were pledged to the same economic policy in the interest of the masses and their right to the cheapest international markets, and the Radicals who, though middle-class, had to show their opposition to the other parties by putting up a nationalistic criollista platform.

The effect of immigration upon the middle-classes was, on the surface, paradoxical. On the one hand it has been seen that they were its originators: directly, by forming a large proportion of it, and indirectly, by virtue of their role in the country's expansion, which created a more diversified social structure, in which a middle-class could exist. They were the productive element of their class and yet their influence was of little immediate penetrating consequence. 


\section{(iii) (b) The sons of immigrants}

The reason why this category is inserted under the general umbrella of the middle-classes is not meant to indicate that all belonged to this strata of society, but stems from the fact that a large majority of second generation immigrants had social aspirations which are most closely associated with the traditional picture of the middle-class. It has been observed that this class was split in Argentina between the native population, who veered towards bureaucratic jobs of government dependence, and the more enterprising immigrants who preferred the greater economic opportunities to be found in the commercial and industrial field. Yet the second generation brought up mostly at a time when the spirit of liberal cosmopolitanism, free enterprise and belief in the survival of the fittest was beginning to change towards a more inward-looking nationalistic attitude, often repudiated their parents' values and way of life, adopting instead the outlook and attitudes of the criollo. ${ }^{55}$ This manifested itself in many interrelated ways.

In their desire to become acriollados they pursued occupations which they considered more in tune with local values. Many moved away from the overtly materialistic occupations of commerce and industry to follow academic studies, showing particular preference for the liberal arts. They found employment in the Civil Service, in the Armed Forces, in the teaching profession, and in the Church. ${ }^{56}$ But above all they studied Law, the profession of greatest prestige, and many joined the numbers of redundant lawyers!

In politics their role too is identified most closely with the middle-class. Socialism, with its international interests, reminded them too closely of their origins, but the Radical Party, whose xenophobia did not extend beyond first generation immigrants, projected a platform which they found very appealing. Their interests coincided and there existed, in fact, a close co-operation between the Radicals and this group. ${ }^{57}$ This process of acculturation had the short term effect of delaying the economic and even political transformation of Argentina, but it did provide a bridge between the two separate societies: the immigrants and the criollo population. 
A backward glance at the way in which immigration as a whole affected the basic structure of Argentina will reveal that the sweeping changes in the country's demographic composition, the spectacular growth in its economic output, and the diversification of its social system, were phenomena that reflected a pattern of evolution rather than one of transformation. They were merely the acceleration and the culmination of the movement towards the coast, and towards a port-dominated economic policy which had started with the decline of silver mining in Peru and the subsequent creation of the Viceroyalty of the Río de la Plata. At the end of period under review there had been no basic alteration in the traditional power structure of pre-immigration Argentina, which rested exclusively with the small criollo élite, largely the descendants of that same criollo élite who had seen the possibilities of a mercantilistic economy based upon the high yield of the country's fertile coastal plains. Yet if the view is extended beyond this period, then it is possible to see it not merely as the apotheosis of an era, but more significantly, as the formative beginnings of a new Argentina, and the evolutionary process mentioned as part of a larger dynamic process of revolutionary transformation.

This transformation was motivated in general terms by the changing nature of the international system of division of labour, within which the unequal dependent position of periphery countries was made acutely manifest during the World Depression of 1929. It resulted in the transition of Argentina as a country with a basically simple two-tiered society and dependent rural export economy, into a nation which was becoming increasingly diversified and complex in social and economic terms, and whose overriding aim was greater self-sufficiency. This could only be achieved by the expansion of the industrial sector, with all the social and political upheavals that such a change inevitably brought in its wake. The fact that Argentina was able to embark upon such a venture is owed in great measure to those hundreds of thousands of immigrants who had crossed the ocean to make their fortune, and stayed to make the new Argentina.

Yet the deepest, most fundamental change that immigration brought with it occurred not at the more objective levels of economics and politics, but at the very roots of society itself, in its ethnic and cultural composition. This may be why the portrayal of immigration in the literature studied concerned itself so particularly with these aspects of immigration. 


\section{FOOTNOTES TO APPENDIX}

\section{SECTION I}

1 See James R. Scobie, Argentina, a City and a Nation (New York, 1971), p. 4 and pp. 26-9. And also John Lynch, Spanish Colonial Administration 1782-1810 (London, 1958), pp. 25-45.

2 G. Pendle, Argentina (London, 1961), second edition, pp. 12-13.

3 See J. Lynch, The Spanish American Revolution. (1808-1926) (London, 1973), p. 32 .

4 H. S. Ferns, Argentina op.cit., p. 33, and also Scobie, op.cit., pp. 60-3.

5 Scobie, ibid., p. 60.

6 Lynch, The Spanish American Revolution ..., pp. 38-9.

7 For a discussion as to 'Who profited by the revolution of 1810 ?', see Lynch, ibid., pp. 64-6.

8 Scobie, op.cit., pp. 76-8 and pp. 133-7, and Ferns, op.cit., pp. 55-7. For a more detailed discussion of this point see Miron Burgin. The Economic Aspects of Argentine Federalism, 1810-1852, pp. 3-17.

9 J. A. Ramos, Revolución y Contrarrevelución en la Argentina, 5 vols (Buenos Aires, 1965), I, p. 33:

Mientras Buenos Aires se perfumaba y bailaba minué, el interior era reducido a la desesperación: diezmadas por las guerras de independencia, arruinadas por la invasión de mercaderías británicas y usurpadas sus rentas por la orgullosa metrópoli, las provincias argentinas se replegaron. Surgieron entonces jefes armados al mando de tropas irregulares que defendieron como pudieron 'las autonomías' provinciales y resistieron la política absorbente de Buenos Aires. Los caudillos aparecieron cuando Moreno había dejado de existir y con él una política genuinamente nacional. Así nació el 'federalismo' resultado del despojo de la riqueza argentina por una sola provincia. El monopolio bonaerense hizo del país su propia colonia.

10 M. Burgin, op.cit., pp. 34-40.

11 Scobie, op.cit., 'An Agricultural Revolution on the Pampas', pp. 112-35. J. a. Ramos, op.cit., volume II, p. 95.

12 Scobie, op.cit., p. 115:

In this interval the country was governed by the so-called oligarchy, a dignified, educated, progressive and haughty élite composed of nineteenth century liberals anxious to advance Argentine prosperity, Catholics who supported anticlerical measures designed to reduce the Church's economic and political powers, men strongly imbued with European and particularly French culture, writers and thinkers dominated by the scientific and materialistic values of positivism, politicians closely associated with landholding interests and with British capital, and statesmen ambitious not only to transform Buenos Aires into the Paris of South America, but also to make Argentina a leading nation of the western hemisphere. 
13 J. B. Alberdi, Bases y puntos de partida para la organización política de la República Argentina (Besançon, 1856). The title 'Gobernar es poblar' does not appear in the 1852 Buenos Aires edition.

14 H. S. Ferns, op.cit., p. 100.

15 See P. A. Joslin, A Century of Banking in Latin America (London, 1963), pp. 28-60 and pp. 96-133.

16 As this relationship is often expressed with varying opinions in contemporary literature, it is relevant to include some background information:

Latin America attracted European and particularly British investment even before Independence, but in the middle of the nineteenth century, coinciding with the end of anarchy in Argentina, an interesting shift occurred in the pattern of investment. It moved from the western coast to the Atlantic and as far as Britain was concerned, chiefly to Argentina. Furthermore, there was a change in the type of investment which turned from Government loans to joint stock companies. This meant a loosening of capital in the private sector and resulted in an economy which was based upon financial speculation rather than on production. But the main effect of investment was to finance the development of the economy by building up a sufficiently sophisticated infrastructure to cope with problems of transport, communication and other service industries and to invest in more modern techniques of agricultural production. This was achieved principally with British capital, which worked in close conjunction with the interest of the local ruling class. A few selected figures illustrate the nature of the partnership:

(i) In the $1880 \mathrm{~s} 40 \%-50 \%$ of all British capital invested outside the U.K. not the British Empire - was to be found in Argentina. (Ferns, Britain and Argentina in the Nineteenth Century, p. 397).

(ii) A million pounds invested in the $1880 \mathrm{~s}$ in Argentine railways produced the highest yield on capital on investment anywhere in the world (ibid., p. 407).

(iii) In the 1880 s frozen Argentine mutton could be bought more cheaply in Manchester than in Buenos Aires (ibid., p. 417).

Furthermore, Britain and Argentina were each other's best customers in an interchange of manufactured goods and agricultural products. This relationship continued until 1913 when there were great pressures upon Britain to turn to her own colonies.

17 Scobie, op.cit., p. 137.

18 Most of the information in this sub-heading is to be found in Scobie, op.cit., pp. 27-32, 64-87, and 112-35, and in 'Etapas del desarrollo económico argentino', by Guido Di Tella and Manuel Zymelman, in Argentina, sociedad de masas (Buenos Aires, 1965), pp. 177-90.

19 Introduction by H. Graham Cannon in C. Darwin, The Voyage of the Beagle (New York, 1975), pp. v-vii.

\section{SECTION II}

1 O. Cornblit, E. Gallo and A. A. O'Connell, 'La generación del 80 y su proyecto: antecedentes y consecuencias', in Argentina, sociedad de masas, op.cit., p. 26. 
2 G. Germani, Política y sociedad en una época de transición (Buenos Aires, 1962), p. 183.

3 Scobie, Argentina, a City and a Nation, op.cit., p. 29.

4 J. Lynch, Spanish American Revolutions ..., p. 38.

5 D. Rosenblat, La población indígena y el mestizaje en América, 2 Vols., (Buenos Aires, 1954), II, pp. 127-32. E. Endrek, El mestizaje en Córdoba, Cuadernos de Historia, XXXIII, Córdoba, pp. 27-8.

6 Scobie, op.cit., p. 107.

7 Argentine Constitution of 1853.

8 In Alsina, La inmigración europea en la República Argentina (Buenos Aires, 1898), pp. 85-97, the date is given as 19 October 1876.

9 Ley Avellaneda, see F. L. Sabsay, Historia económica y social argentina II (Buenos Aires, 1967), pp. 303-312.

10 Alsina, op.cit., p. 85.

11 Scobie, op.cit., p. 98.

12 G. Germani, Estructura social de la Argentina (Buenos Aires, 1955), p. 21.

13 ibid., p. 81.

14 Germani, Politica y sociedad ..., p. 186.

15 ibid., p. 187. For these and subsequent figures see pp. 181-210.

16 H. S. Ferns, Argentina p. 96.

17 Only in New York, a city, was the percentage higher. Otherwise, the proportion of immigrants to the native-born population of Argentina far exceeded that of the U.S.A. See D. Rock, Politics in Argentina, 1890-1930 (London, 1975, p. 10.

18 J. A. Alsina, La inmigración en el primer siglo de independencia (Buenos Aires, 1910), pp. 53-9.

19 A. Ramos regrets that the closed protectionist policies of the interior were not followed because, he argues, that would have saved the country from embarking upon a road which led to dependence upon what he calls the Imperialistic Powers of the industrialized nations. He cites as a desirable example the early autonomous development of Paraguay, which he calls 'una de las primeras potencias sudamericanas'. This view may be contrasted with that of J. Lynch, who sees Paraguay's policy of enclosed indespendence and autarchy as a path which led to social and economic stagnation. See Ramos, op.cit., pp. 36-46 and J. Lynch, Spanish American ..., op.cit., pp. 104-17.

20 Scobie, op.cit., p. 145.

21 E. Gallo, Farmers in Revolt, the Revolutions of 1893 in the Province of Santa Fe, Argentina (London, 1976), pp. 32-7.

22 Scobie, op.cit., p. 119.

23 G. Germani, Politica y sociedad ..., p. 191; Cortés Conde, 'El boom argentino: ¿una oportunidad desperdiciada?', in Los fragmentos delpoder, edited by T. S. Di Tella and T. Halperín Donghi (Buenos Aires, 1969), p. 234, and N. E. Dickman, Población e inmigración (Buenos Aires, 1946), pp. 143-4.

24 Germani, Política y sociedad ..., op.cit., p. 203.

25 Germani, ibid., p. 186.

26 Ferns, op.cit., p. 126. 
27 Cortés Conde, 'Problemas del crecimiento industrial (1870-1914)', in Argentina sociedad de masas, op.cit., pp. 59-83.

28 Scobie, op.cit., p. 131.

29 Ramos, op.cit., pp. 280-1.

30 Cortés Conde, op.cit., pp. 69-70.

31 See G. Beyhaut, R. Cortés Conde, H. Gorostegui de Torres and others, 'Los inmigrantes en el sistema ocupacional argentino', in Argentina sociedad de masas, op.cit., p. 119, and for a more extensive study pp. 85-123. Germani notes that $80 \%$ of commercial and industrial entrepreneurship was under immigrant ownership: see Germani, Política y sociedad ..., op.cit., p. 194.

32 Ferns, op.cit., p. 102.

33 J. r. Scobie, Buenos Aires, Plaza to Suburb, 1870-1919(New York, 1974), p. 208.

34 Germani, Estructura social ..., p. 205.

These figures are used merely as a rough guideline, for they refer in fact to a somewhat later period than the one here under review. Also Germani has reservations about their exactness. He writes, however:

La determinación estadística precisa de esta clase no tiene excesiva importancia. Su fuerza y significado, en efecto, no reside en el número sino en su composición interna, en su posición dentro de la estructura econó-

mica y en su relación con el resto de la sociedad. (p. 198).

35 J. L. de Imaz, La clase alta de Buenos Aires (Buenos Aires, 1962), pp. 12-13.

36 J. L. Romero, Las ideas políticas en Argentina (Mexico-Buenos Aires, 1959), p. 181.

37 Cortés Conde, 'Problemas del crecimiento industrial', op.cit., p. 62.

38 D. Rock, 'Machine Politics in Buenos Aires and the Argentine Radical Party, 1912-1930', in Journal of Latin American Studies, 4, 1972, p. 234.

39 Conventillos: tenement dwellings. See p. 144, note 21.

40 According to Ramos a surplus of workers was brought in by the Conservative Government of the 1890 s to have what he calls 'un ejército industrial de reserva', and thus keep salaries and demands for social reform, low. See op.cit., p. 254. Cortés Conde supports this assertion in El boom argentino, op.cit., p. 231, and writes that in fact salaries dropped from two pesos in 1886 to 1.15 pesos in 1892 and 1.13 pesos in 1894 .

41 J. Vazeilles, Los socialistas (Buenos Aires, 1967), pp. 13-40.

42 Romero, op.cit., pp. 177 and 176 respectively.

43 Germani, Estructura social ..., p. 136.

44 O. Cornblit, 'Inmigrantes y empresarios en la política argentina', in Los fragmentos del poder, op.cit., pp. 389-437.

45 The bulk of information on anarcho-syndicalism stems from Fanny Simons, 'Anarchism and Anarcho-Syndicalism in South America', Hispanic American Historical Review, February 1946, 26, pp. 38-59.

46 Germani, Política y sociedad..., pp. 204-5.

47 Scobie, Argentina, op.cit., p. 202.

48 Scobie, ibid., pp. 174-5 and also Alsina, op.cit., p. 330.

49 Germani, ibid., p. 189.

50 A division of middle-class occupations into bureaucratic employment or sinecures dependant upon government hand-outs on the one hand, and active production on the other, shows that the former attracted a predomi- 
nantly criollo work force whereas the latter attracted an immigrant one.

Germani, Estructura social ..., pp. 120-3.

51 Scobie, Buenos Aires, Plaza ...op.cit., p. 179.

52 F. Korn, 'Algunos aspectos de la asimilación de inmigrantes en Buenos Aires', in Los Fragmentos, op.cit., pp. 439-59.

53 Ferns, op.cit., pp. 128-9.

54 Di Tella, in Los Fragmentos, op.cit., p. 283.

55 Ferns, ibid., p. 134.

57 Rock, op.cit., pp. 55-6. 
BIBLIOGRAPHY 


\section{SELECTED BIBLIOGRAPHY OF ARGENTINE FICTION}

For a bibliography of Argentine fiction in the nineteenth century, see: Lichtblau, Myron, The Argentine Novel in the Nineteenth Century. New York, 1959.

For a bibliography on the immigrant in the Argentine novel, see: García, Germán, El inmigrante en la novela argentina. Buenos Aires, 1970.

Alberdi, Juan B., Peregrinación de Luz del Dia: Viaje y Aventuras de la Verdad en el Nuevo Mundo. Buenos Aires, 1871. See also:

-. Luz del Día en América. Buenos Aires: Biblioteca Argentina, 1916.

-. Peregrinación de Luz del Dia. Prologue by M. García Mérou. Buenos Aires: La Culta Argentina, 1916.

-. Escritos Póstumos. Buenos Aires: Angel Estrada y Cía., 1945.

Alvarez, José S., (Fray Mocho), Cuentos de Fray Mocbo. Buenos Aires, 1906.

Argerich, Antonio, Inocentes o culpables. Buenos Aires: Imprenta del Courrier de la Plata, 1884.

Bahamonde, Manuel, Abismos. Buenos Aires: Lajouane, 1890.

Cambaceres, Eugenio, En la sangre. Buenos Aires: EUDEBA, 1967.

-. Sin Rumbo. Introduction and notes by Teresita Frugoni de Fritzsche. Buenos Aires: Plus Ultra, 1968.

-. Obras Completas. Observations and notes by E.M.S. Danero. Buenos Aires: Editorial Castellvi, 1968.

Cantilo, José Luis, Quimera. Buenos Aires: Librería Bredahl, 1899.

Echeverría, Esteban, El Matadero. Eighth edition. Buenos Aires: Editorial Sopena, 1965.

Ezcurra, Eduardo de, Buenos Aires en el siglo XX. Buenos Aires: Imprenta de Juan Alsina, 1891.

Gouchon Cané, Emilio, El 90. Buenos Aires.

Grandmontagne, Francisco, Teodoro Foronda: Evoluciones de la sociedad argentina. 2 vols. Buenos Aires: La Vasconia, 1896.

-. La Maldonada. Buenos Aires: Imprenta Artística, 1898.

Güiraldes, Ricardo, Don Segundo Sombra. Buenos Aires, 1926. Also in:

-. Obras Completas. Buenos Aires: Emecé, 1962.

Hernández, José, Martín Fierro. With a study by Eleuterio F. Tiscornia. Buenos Aires: Losada, 1953.

Mármol, José, Amalia. Buenos Aires, 1855.

Martel, Julián, La Bolsa. Buenos Aires: Clásicos Argentinos, 1971.

Morante, Pedro, G., Grandezas. Buenos Aires: Lajouane, 1896.

Ocantos, Carlos María, Quilito. Paris: Garnier, 1891.

-. Promisión. Buenos Aires: La Nación, 1914. 
Payró, Roberto, Divertidas aventuras del nieto de Juan Moreira. Sixth edition. Buenos Aires: Losada, 1971.

Podestá, Manuel, Irresponsable. Buenos Aires: Imprenta de la Tribuna Nacional, 1889.

Saavedra, Osvaldo, Grandezas chicas. Buenos Aires, 1901.

Saldías, Adolfo, Bianchetto: La patria del trabajo. Buenos Aires: Lajouane, 1896.

Sarmiento, Domingo Faustino, Facundo: Civilización y barbarie. Buenos Aires, 1845.

-. Recuerdos de Provincia. Buenos Aires: Emecé, 1944.

Sicardi, Francisco, Libro extraño. 2 vols. Barcelona: Granada y Cía. N/D.

-. Horas de evolución. Buenos Aires: Jesús Hernández editor, 1938.

Solar, Alberto del, Contra la marea. Buenos Aires: Lajouane, 1894.

Villafañe, Sengundo I., Horas de fiebre. Buenos Aires: Imprenta de Juan Alsina, 1891.

\section{DICTIONARIES AND ENCYCLOPAEDIAS}

Biograpbie Universelle: Ancienne et Moderne. 45 vols. Paris: A. Thoisnier Éditeur, 1852.

Diccionario Critico etimológico de la lengua castellana. Edited by J. Corominas. Madrid: Edición Gredos, 1954.

Diccionario de Americanismos. Buenos Aires: Muchnich Editores, 1966.

Diccionario Histórico Argentino. Buenos Aires: Ediciones Históricas Argentinas, 1853-4.

Dictionary of Pbilosopby. Edited by D. D. Runes. London: Peter Owen, 1972.

Enciclopedia de la Literatura Argentina. Buenos Aires: Sudamericana, 1970.

Encyclopaedia Judaica. Jerusalem, 1974.

Gran Enciclopedia Argentina. Buenos Aires: EDIAR, 1956.

\section{CRITICAL WORKS ON ARGENTINE LITERATURE}

Anderson Imbert, Enrique, Spanish American Literature. 2 vols. Michigan: Wayne State University Press, 1969. Second edition.

Andersson, Theodore, Carlos Maria Ocantos: Argentine Novelist. New Haven: Yale University Press, 1934.

Ara, Guillermo, La novela naturalista en Hispanoamérica. Buenos Aires: EUDEBA, 1965.

-. Los argentinos en la literatura nacional. Buenos Aires: Huemul, 1966.

Argerich, Antonio, Naturalismo. Buenos Aires: Imprenta de Ostwald, 1882.

Arrieta, Rafael A., Historia de la Literatura Argentina, 6 vols. Buenos Aires: Peuser, 1958-60.

Arrom, J. J., Esquema generacional de las letras bispanoamericanas. Bogotá: Instituto Caro y Cuervo, 1963.

Bagú, Sergio, 'Julián Martel y el Realismo Argentino: Una Revaloración de La Bolsa', Separata de la revista Comentario. Buenos Aires, 1956.

Blasi Brambilla, Oscar, Los fundadores. Buenos Aires: Ediciones Culturales Argentinas, 1962. 
Bunkley, Allison W., The Life of Sarmiento. New Jersey: Princeton University Press, 1952.

Canal Feijóo, Bernardo, Constitución y Revolución: Juan Bautista Alberdi. Buenos Aires: Fondo de Cultura Económica, 1955.

Castro Leal, A., 'El Facundo de Domingo Faustino Sarmiento', Cuadernos Americanos, IV, 5, 1945.

Crawford, W. R., A Century of Latin American Thought. Cambridge, Massachusetts: Harvard University Press, 1963.

Cúneo, Dardo, Sarmiento y Unamuno. Buenos Aires: Pleamar, 1963.

-. and others, Inmigración y Nacionalidad. Buenos Aires: Paidós, 1967.

-. Las propias vanguardias. Buenos Aires: Edición del Ministerio de Cultura y Educación, 1973.

Diez-Echarri, Emiliano and Roca Franquesa, José M., Historia de la Literatura Española e Hispanoamericana. Second edition. Madrid: Aguilar, 1966.

Franco, Jean, The Modern Culture of Latin America: Society and the Artist. London: Pall Mall Press, 1967.

-. An Introduction to Spanish American Literature. London: Cambridge University Press, 1968.

García, Germán, La novela argentina. Buenos Aires: Sudamericana, 1952.

-. El inmigrante en la novela argentina. Buenos Aires: Hachette, 1970.

García Merou, Martín, Libros y Autoras. Buenos Aires: Lajouane, 1886.

-. Recuerdos literarios. Buenos Aires: La Cultura Argentina, 1915.

Ghiano, Juan C., Testimonio de la novela argentina. Buenos Aires: Leviatán, 1956.

Jitrik, Noé, El 80 y su mundo. Buenos Aires: Jorge Alvarez, 1968.

-. Muerte y resurrección de Facundo. Buenos Aires: Centro Editor de América Latina, 1968.

-. Ensayos y estudios de literatura argentina. Buenos Aires: Galerna, 1970.

Lichtblau, Myron, The Argentine Novel in the Nineteenth Century. New York, 1959.

Loveluck, Juan, editor, La novela bispanoamericana. Concepción, Chile: Editorial Universitaria, 1966.

Magis, Carlos H., La literatura argentina. Mexico: Editorial Pormaca, 1965.

Martínez Estrada, Ezequiel, Para una revisión de las letras argentinas. Buenos Aires: Losada, 1967.

Napolitano, Emma, Francisco A. Sicardi. Buenos Aires: Imprenta de la Universidad, 1942.

Onega, Gladys, La inmigración en la literatura argentina, 1880-1910. Buenos Aires: Galerna, 1968.

Palcos, A., Sarmiento: La vida, la obra, las ideas, el genio. Buenos Aires: El Ateneo, 1929.

-. El Facundo: Rasgos de Sarmiento. Second edition. Buenos Aires: Elevación, 1945.

Pérez Amuchástegui, A. J., Mentalidades argentinas (1860-1930). Buenos Aires: EUDEBA, 1965.

Prieto, Adolfo, La literatura autobiográfica argentina. Buenos Aires: Jorge Alvarez, 1966.

-. Diccionario básico de literatura argentina. Buenos Aires: Centro Editor de América Latina, 1968. 
Rhode, Max, Las ideas estéticas en la literatura argentina, 4 vols. Buenos Aires: Coni, 1921-6.

Rojas, Ricardo, Historia de la literatura argentina, 9 vols. Buenos Aires: Guillermo Kraft, 1960.

Rusich, Luciano, El inmigrante italiano en la novela del 80. Madrid: Playor, 1974.

Sanchez, Luis Alberto, Proceso y contenido de la novela bispanoamericana. Madrid: Gredos 1953.

Valera, Juan, Ecos Argentinos. Madrid, 1901.

Verdevoye, Paul, Sarmiento: Éducateur et Publiciste. Paris: Centre de Recherches de l'Institut d'Études Hispaniques, 1964.

Viñas, David, Literatura argentina y realidad política. Buenos Aires: Jorge Alvarez, 1964.

-. De Sarmiento a Cortázar. Buenos Aires: Siglo Veinte, 1971.

-. Grotesco, inmigración y fracaso. Buenos Aires: Corregidor, 1973.

Weinberg, Félix, Vida e imagen de Sarmiento, Buenos Aires: EUDEBA, 1963.

Williams Álzaga, E., La Pampa en la novela argentina. Buenos Aires: Estrada, 1955.

Zum Felde, Alberto, Indice critico de la narrativa bispanoamericana, 2 vols. México: Guarania, 1954 and 1959.

\section{GENERAL WORKS ON ARGENTINE HISTORY AND CULTURE}

Alberdi, Juan Bautista, Bases y puntos de partida para la organización política de la República Argentina. Buenos Aires: 1852 and Buenos Aires: La Cultura Argentina, 1960.

-. Las Quillotanas, o cartas sobre la prensa y política militante. Buenos Aires: La Cultura Argentina, 1916.

-. La barbarie bistórica de Sarmiento. Buenos Aires: Argentina profunda, 1964.

Alsina, Juan A., La inmigración en el primer siglo de la independencia. Buenos Aires: Alsina, 1910.

Bunge, Carlos Octavio, Nuestra América. Buenos Aires: Vaccaro, 1918.

Burgin, Miron, The Economic Aspects of Argentine Federalism: 1820-1957. Cambridge, Massachusetts, 1946.

Cochran, T. C. and Reina, R. E., Entrepreneurship in Argentine Culture. Philadelphia: University of Pennsylvania Press, 1962.

Dickman, Enrique, Población e inmigración. Buenos Aires: Losada, 1946.

Di Tella, T., Germani, G., and others, Argentina: sociedad de masas. Second revised edition. Buenos Aires: EUDEBA, 1965.

Di Tella, T., Halperín Donghi, T., and others, Los fragmentos del poder. Buenos Aires: Jorge Alvarez, 1969.

Eisenstadt, S. N., The Absorption of Immigrants. London: Routledge and Kegan Paul, 1954.

Endrek, Emiliano, El mestizaje en Córdoba: Siglo XVIII y principios del XIX. Córdoba, Argentina: Universidad Nacional de Córdoba, 1966. 
Gallo, Ezequiel, Farmers in Revolt: The Revolutions of 1893 in the Province of Santa Fe, Argentina. London: The Athlone Press, 1976.

Ferns, H. S., Britain and Argentina in the Nineteenth Century. London: Oxford University Press, 1960.

-. Argentina. London: Benn, 1969.

Germani, Gino, Estructura social de la Argentina. Buenos Aires: Raigal, 1955.

- Política y sociedad en una época de transición. Buenos Aires: Paidós, 1965.

Gori, Gastón, Inmigración y colonización en la Argentina. Buenos Aires: EUDEBA, 1964.

Imaz, José Luis de, La clase alta de Buenos Aires. Buenos Aires: Estructurar, 1962.

-. Los que mandan. Buenos Aires: EUDEBA, 1964.

Ingenieros, José, La evolución de las ideas argentinas. Edited by Aníbal Ponce. Buenos Aires: Problemas, 1946.

Jefferson, M., Peopling the Argentine Pampa. New York: American Geographical Society, 1926.

Jones, Cyril A., Sarmiento: Facundo. London: Tamesis, 1974.

Joslin, P., A Century of Banking in Latin America. London: Oxford University Press, 1963.

Lewin, Boleslao, Cómo fue la inmigración judia a la Argentina. Buenos Aires, Plus Ultra, 1971.

Lynch, John, Spanish Colonial Administration: 1782-1810. London: The Athlone Press, 1958.

-. Spain under the Hapsburgs. 2 vols. Oxford: Basil Blackwell, 1965.

-. The Spanish American Revolution: 1808-1826. London: Weidenfeld and Nicholson, 1973.

Pendle, George, Argentina. London: Oxford University Press, 1961.

Ramos, Jorge Abelardo, Revolución y Contrarrevolución en la Argentina, 5 vols. Fifth edition. Buenos Aires: Plus Ultra, 1973.

Rock, David, 'Machine Politics in Buenos Aires and the Argentine Radical Party: 1912-1930', in Journal of Latin American Studies, 4, 1972.

-. Politics in Argentina, 1890-1930: The Rise and Fall of Radicalism. London: Cambridge University Press, 1975.

Romero, José Luis, Las ideas políticas en Argentina. Buenos Aires: Fondo de Cultura Económica, 1959.

Rosenblat, D., La población indígena y el mestizaje en América, 2 vols. Buenos Aires: Nova, 1954.

Sabsay, Fernando L., Historia económica y social argentina II. Buenos Aires: Omeba, 1967.

Sarmiento, Domingo F., Obras, 53 vols. Buenos Aires: Borzone, 1903.

Saldías, Adolfo, Historia de la Confederación Argentina: 1829-1862, 5 vols. Buenos Aires, 1892.

-. La Politique Italienne au Rio de la Plate: La condition des étrangers devant le droit international. Paris: L. Sauvaitre.

Scobie, James R., Buenos Aires: Plaza to Suburb, 1870-1910. New York: Oxford University Press, 1974.

-. Argentina: A City and a Nation. Second edition. New York: Oxford University Press, 1971. 
Simon, S. Fanny, 'Anarchism and Anarcho-Syndicalism in South America', Hispanic American Historical Review, 26, 1, 1946.

Solberg, Carl, Immigration and Nationalism: Argentina and Chile, 1890-1914. Austin: University of Texas Press, 1970.

Stein, Syanley J. and Barbara H., The Colonial Heritage of Latin America. New York: Oxford University Press, 1970.

Vazeilles, José, Los socialistas. Buenos Aires: Jorge Alvarez, 1967.

Walter, Richard J., The Socialist Party of Argentina, 1890-1930. Austin: University of Texas Press, 1977.

\section{OTHER WORKS CITED OR CONSULTED}

Allport, Gordon W., The Nature of Prejudice. Cambridge, Massachusetts: Harvard University Press, 1955.

Auerbach, Erich, Mimesis. Second edition. New Jersey: Princeton University Press, 1973.

Barthes, Roland, Le degré zéro de l'écriture. Paris: Seuil, 1953.

-. Elements de Semiologie. Paris: Seuil, 1964.

-. S/Z. Translation and Introduction by Richard Howard, London: Cape, 1975.

Biddiss, M. D., Father of Racist Ideolgy. New York: Weybright and Telley, 1950.

Booth, Wayne C., The Rbetoric of Fiction. London: The University of Chicago Press, 1961.

Borges, Jorge Luis, Prólogos. Buenos Aires: Torres Agüero, 1975.

Burgin, Richard, Conversations with Jorge Luis Borges. London: Souvenir Press, 1973.

Darwin, Charles, On the Origin of Species by Means of Natural Selection or the Preservation of Favoured Races in the Struggle for Life. First published in 1859. London: Watts and Co., 1950.

Drumont, Edouard A., La France Juive, 2 vols. Paris: C. Marpon et E. Flammer 1886.

Forster, Edward M., Aspects of the Novel. London: Arnold, 1927.

Frye, Northop, Anatomy of Criticism. Third edition. New Jersey: Princeton University Press, 1973.

Gerbi, Antonio, La Disputa del Nuevo Mundo. Second edition. México: Fondo de Cultura Económica, 1960.

Goldman, Lucien, Pour une sociologie du roman. Paris: Gallimard, 1964.

Katz, J., 'A State within a State: The History of an Antisemitic Slogan', Proceedings of the Israel Academy of Sciences and Humanities, IV, 3, Jerusalem, 1967.

Kolakowski, Leszek, Positivist Pbilosopby London: Pelican Books 1972.

Le Bon, Gustave, Les lois psychologiques de l'évolution des peuples. Paris: Félix Alcan, 1894.

Lida de Malkiel, M. R., Horacio en la literatura mundial. Buenos Aires: Ariel, 1975.

Lubbock, Percy, The Craft of Fiction. London: Cape, 1921.

Lukács, Georg, Studies in European Realism. London: The Merlin Press, 1972.

-. The Meaning of Contemporary Realism. London: The Merlin Press, 1972.

Macherey, Pierre, Pour une Théorie de la Production Littéraire. Paris: Maspero, 1971. 
Martineau, Harriet, The Positive Philosopby of Auguste Comte, 2 vols. London: John Chapman Series, volumes 3 and 4, 1953.

Muir, Edwin, The Structure of the Novel. Tenth impression. London: The Hogarth Press, 1967.

Paz, Octavio, El Laberinto de la Soledad. Revised edition. México: Fondo de Cultura Económica, 1970.

Rodó, J. Enrique, Ariel. Edited by Gordon Brotherston. Cambridge: Cambridge University Press, 1967.

Taine, Hyppolite, 'Introduction to the History of English Literature', in Revue Germanique et Francaise, Paris, 1863.

Veblen, Thorstein, The Theory of the Leisure Class. London: Unwin Books, 1970.

Webb, Daniel, A General History of the Americans: Selected from M. Paww. Rochdale, 1806.

Wellek, R., Concepts of Criticism. New Haven: Yale University Press 1963.

Wellek, R. and Warren, A., Theory of Literature. Third edition. London: Penguin Books, 1973.

Zola, Émile, Le Roman Expérimental. Second edition. Paris: Charpentier, 1880. 
Alberdi, Juan B.

admiration of Europe, 32, 40; anasis of Argentina's needs, 34; article in La Moda, 197-8; decries glorification of war, 38; and degenerating effect of America, 36, 158; and education, 42; as 'Figarillo', 37; on importance of climate, 40-1; language, 37; and Martel, 107, 108; materialism, 38-40; political programme, 37-8; racism, 41-2; and Sarmiento, 32, 41-2; style, 33; and superiority of Anglo-Saxons, 37, 40, 198; two voices in Peregrinación, 34; views on immigration, 32, 34, 38-43, 108126 see also Peregrinación...

Allport, G. W. 201, 204

Alsina, Juan A. 226

Alsinistas 123, 130, 205

Amalia (Mármol) 15, 16, 29, 48, 195

Anarcho-syndicalism 234-5

Andrès (Sin rumbo) 72

Animal imagery 59, 75, 85-9

Anti-Semitism 93-4; 98-101, 110-4, 203 see also Jews, Racism

Ara, G. 50, 55, 199

Argentina

Baring Crisis, 82, 93, 231; British investment, 218, 241; cattle raising, 219-20; class structure, 232-8; colonial era, 213-4; Constitution of 1853 , 32, 223; crop farming, 220-1; demographic changes, 224; depression in 1890s, 183; disappearance of negroes and mulattoes from, 181; economic growth, 47, 119, 216-21, 226-31; economic situation, 1880s, 93; emigration, 225; foreign residents in, 229; 243; government by oligarchy, 240; immigration policy, 223; independence, 105, 214-6; industrial expan- sion, 229-30; Ley Avellaneda, 223; middle class, 236-7; needs analysed by Alberdi, 34; population, 224-5; railways, 219 ; in second half of nineteenth century, 216; shares market collapse, 82, 93, 231; sheep raising, 220; shipping, 219; social impact of immigrants, 231-7; trade with Europe, 217-8

see also Immigrants, Immigration

Argentine literature

Criollismo, 120; elitist, 48; influence on society, 47, 48, 50, 51; novels and social reality, 8-9; 49; number of novels published, 45; plays, 8; popular writings, 199; School of Naturalism, 48-52, 199; School of Realism, 48-9, 52

Argerich, Antonio 50, 199-200 characters, 65-7; criollo social code, 63; derogatory references to immigrants, 60; heredity and characters, 65-7; inconsistency of characterisation, 61; lack of knowledge of immigrant society, 67, 69; livestock breeding, 54, 200; and Malthusian arguments, 54; prejudices against characters, 58-9; understanding of criollo society, 67; views on immigration, 53-5; and Zola, 57 see also Inocentes o culpables

Ariel (Rodó) 120, 198

Atapuerca, Don Pantaleon (Teodoro Foronda) 143-5, 151

Auerbach, Eric 194

Autonomistas 123

Avellaneda, Nicolas 224

Baring Crisis (shares market collapse) $82,93,231$

Bagú, Sergio 110, 112 
Barbarism

Argerich's concept, 54; in Facundo, 17-21, 25, 30-1; Sarmiento's concept, 18-21, 25, 54

Bases (Alberdi) 34, 39-40, 198

Bianchetto: la patria del trabajo (Saldias) 121-37

America as Utopia in, 125-6, 130; attitude to Europe in, 125, 126, 127; Buenos Aires in, 128-9; didacticism, 134, 135, 206; gaucho's way of life in, 129; idealisation of criollos, 130, 133; life in Genoa depicted, 122, 127; naivete, 121; military service, 121, 134; naturalisation of immigrants, 121,134 ; need for immigrants in country areas, 129-30; plot, 122-4; political discussion in, 123, 126, 129, 131; Positivist ideology in 122, possibility of improvement for immigrants in, 122-4, 152, 162; rural life, 128-9; setting, 128-9; women in, 127-8; work as theme, 124-6; writing and publication of, 121 see also Saldías, Adolfo

Bianchetto (Bianchetto)

as gaucho, 125; in Genoa, 122, 124; model immigrant, 136; patriotism, 123, 134; spiritual development, 127, 131-6

Biological determinism 73-4, 119

Blasi Brambilla, Oscar 90, 207

Boca, La, Buenos Aires 122, 125

Bolivar, Don Leandro (Teodoro Foronda) 156-7

Bolivar, Maria (Teodoro Foronda) 140, 149, 206

Bolsa, La (Martel) 48, 92-115

anti-Semitism, 93-4, 98-100, 203; author's rehetorical observations, 105; 'La Bolsa' as temptress, 94, 106-7, 112; condemnation of liberal policy, 92-3; contrasted with Teodoro Foronda, 141; criollo characters, 101-6, 115 ; disparate elements of 'inmigracion', 94; dress as indication of character, 97-8; idealisation of past, 105-6, 130, 204; immigrant charac- ters, 95-8; immigrants' effect on society, 93, 106, 108-14; Jews, 109-14; naturalism, 95; publication, 92,203

see also Martel, Julián

Booth, J. W. 79, 207

Borges, J. L. 196, 198

British

investment, 218, 241; settlers, 43, 198; trade agreements, 214

Buenos Aires (city) 18, 30

anarcho-syndicalism, 234-5; commerce, 213-4; early settlement, 213; employment for immigrants, 230-1; in En la sangre, 90; expansion, 229; immigrants in, 225, 229; Jewish community, 204; in Libro extraño, 177-8; population growth, 53-4; and railways, 219; seat of Viceroyalty, 214; setting for novels, 193

Buenos Aires (province) expense of land, 227; immigrants, 228; migrant harvesters, 228

Buffon, George L. L. Comte 36

Cambaceres, Eugenio 49, 50, 70 horror of poverty, 77-8; knowledge of conventillo, 90; language, 90; manipulation of reader, 79; Onega on, 52; prejudices, 70, 72-3, 77-8, 91 see also En la sangre

Cané, Miguel 121

Carcaneli (La Bolsa) 98

Carlota (Inocentes o culpables) 56-7, 62-3

Carmen (Bianchetto) 128, 135

Celman, Juarez 93, 179

Ciclo de la Bolsa, El 93

Club del Progreso 81, 82, 83, 88, 159

Conde, Cortés 228, 230

Condition des étrangers residents (Saldias) 121

Conservadores 123

Córdoba 30

Correas, Don Jesus Maria 130-1

Crawford, W. R. 33

criollo population 5

americanismo, 29; criollismo, 119-20; definition, 195; depicted in novels, 
52; elite, 9, 232; working class, 233; xenophobia, 235

see also under the titles of individual novels

Dagiore family (Inocentes o culpables) 17 , 56-9

Dagiore, Dorotea 56, 60-3, 69

Dagiore, Jose (father) 56-60, 68-9

Dagiore, Jose (son)

author sympathises with, 67; contracts venereal disease, 57; death, 57, 67; deprived childhood, 56; as illustration of Biological Determinism, 65-7

Darwin, Charles 18, 53, 195, 220

Darwinism 50, 126

Desiderio (Libro extraño) 169

Determinism 50-2

biological, 73-4; in

En la sangre, 71, 73-7; environmental, 119-20; in Inocentes o culpables, 64, 65, 67; pre-determinism, 50-1

Diez-Echarri, Emiliano 26, 196

Dolores, Doña (La Bolsa) 105-6

Don Segundo Sombra (Güiraldes) 120

Don Manuel Paloche see Libro Extraño

Drumont, E. 98, 99, 100, 111

Echeverría, Esteban 15-6, 194

En la sangre (Cambaceres) 48, 70-91 animal imagery in, 85-9; biased presentation of characters, 75; Buenos Aires in, 90; conventillos, 71-2, 77, 90, 202; criollo elite characters, 73, 75, 81-2, 83-4, 89; criollo middle and lower class characters, 77-8, 83; critics on, 90 ; determinism in $71,73-7$, 152; environment v. heredity in, 74 , 77, 201; immigrant characters, 75-6, 89, 91, 151, 152; Indians in, 83; narrative strategy, 79-80; poverty as a sign of 'unfitness'; 77; publication, 70; symbolic significance of blood, 70-1, 73, 201

see also Genaro, Cambaceres, Eugenio

Environmental determinism 119-20
Errécar, Elbio (Libro extraño) 164, 165, $167,181-2$

as political leader, 183, 185-6

Errécar, Martín (Libro extraño) 164-5

Esteban, Don (En la sangre) 74, 76, 84 and animal imagery, 86, 88, 89

Estrada, Manuel 33

Facundo (Sarmiento) 15-31

Barbarism, 17-21, 25, 30-1; Civilisation, 17, 30; criollos' bad influence on Argentina's evolution, 16; and Darwinian thought, 18; embodiments of Civilisation and Barbarism in, 21-2, 25-7; exaggeration in, 195; gauchos in, 18-9, 20-1; Nature in, 20, 129; plea for European immigration in, 16-7, 19, 29, 31; publication of, 17; triumph of Europeanisation predicted, 30

see also Quiroga, Facundo; Sarmiento, Domingo Faustino

Federales 215

and Littoral Provinces, 18; portrayal in novels, 15-6; in power, 47

Ferns, H. 217

Ferreol, Dr. (Inocentes o culpables) 62, 63

'Figarillo', pseudonym of Alberdi 37

'Figaro', pseudonym of Larra 37

Fiori, Ercole (Bianchetto) 132-3, 139, 140

Foronda, Simón, (Teodoro Forunda) $140-1,150$

Foronda, Teodoro, (Teodoro Foronda) 139-141, 147-52

in Anahualpa, 140; in Buenos Aires, 139; compared to Bianchetto, 139, 140; conflict with children, 140-1, 150-2; economic success, 140, 147-8; intelligence, 148; and Maria, 140, 149, 206; spiritual qualities, 151.

Foronda, Teresa, (Teodoro Foronda) 140-1, 150

Franco, J. 49

Francucheli (La Bolsa) 98

Fritzsche, Teresita Frugoni de 90

Gallo, E. 227

Garcia, German 8, 53, 161 
'gaucha' 206

Gauchos 5

change in definition, 195; ethos, 25-6; four types, 21; Guiraldes and, 120; Saldias and, 126; Sarmiento and, 18-21, 195; way of life 20

Genaro, see Libro extraño (for character of that name, see below)

Genaro (En la sangre) 79-85

animal imagery and, 86-9; Cambaceres' prejudices against, 72-3; embodiment of author's ideas on immigration, 76 ; environment $v$. heredity in, 74, 77; faith in immigration, 82; impossibility of escape from his heredity, 79-80; inherited characteristics, 73, 77; lack of intellectual ability, 83; and Màxima, 85; and narrative strategy, 79-80

Genaro (Libro Extraño) 163, 165-6

Gerbi, A. 36

Gerchunoff, Alberto 138, 206

Germani, G. 222, 232, 233, 243

Glow, Dr. (La Bolsa) 102-9

anti-semitism, 104, 110-12; author's bias towards, 102; choice of name, 103; dying nightmare, 106-7; honesty, 103-4; on immigrants, 108-9

Glow, Margarita (La Bolsa) 104, 204

Gobineau, Count 110, 205

Goldman, Lucien 9

Grandmontagne, Francisco 50, 138

attitude to immigrants, 138-9; attitude to second generation immigrants, 151-3, 191; attitude to women, 154, 161; disdain of lawyers, 160; on education, 160; and material opportunities in America, 157-8; on politicians, 160; racism, 156-7 see also Teodoro Foronda

Granulillo (La Bolsa) 102, 104, 110-1

Gray, Juan (La Bolsa) 102

Güiraldes, Ricardo 120

Guriezo, Don Miguel (Teodoro Forunda) 142-3

Hacia la justica see Libro extraño Hernández, J. 134
Herzen (Libro extraño) 187

Hirsch Foundation, Baron 113, 114

Historia de la Confederacíon Argentina (Saldías) 205

Imaz, José Luis de 232

Imbert, Anderson 33, 194

Immigrants to Argentina

anarchists, 235; as civilising influence, 5; in commerce and industry, 236-7, 243-4; different from early expectations, 180-1; expected to adapt to criollo values, 5, 10; German and Swiss, 20; increase in numbers, 47; inferior to criollo population, 5, 10; Jewish, 113-4; lack of integration, 233-4; migrant havesters, 228; naturalisation, 229, 234; number in relation to total population, 47 ; penetration of middle class, 236-7; political parties and, 234; political refugees, 193; second generation, 206-7, 238; separation from political life, 229, 237; social impact of, 231; stereotyped portrayal of in literature, 5, 191-3; in towns, 232-3

see also under the names of individual novels and their authors and characters

Immigration

cause of demographic change, 224; encouragement of, 218-9; in later nineteenth century, 47, 119-20; to Littoral Provinces, 222-3; by nationality, 222; in nineteenth century novels, 8-9; policy, 223; reactions to, 119-20; transformational factors in Argentina, 7, 8; views of, in novels, 9

see also under the names of individual novels and their authors

Inocentes o culpables 53-69

animal metaphors, 59; criollos in, 62-8, 200; criollos share immigrants' characteristics, 64; critics on, 55; determinism in, 64, 65, 67; inconsistency of characterisation, 61-2, 68; plot, 56-7; portrayal of immigration 
in, 68-9; prejudice against characterisation, 61-2, 68; plot, 56-7; portrayal of immigration in, 68-9; prejudice against characters, 58-9; prologue not representative of whole work, $53,55,60,65,67,68$; as socio-historical document, 55; structure, 57-8 see also Argerich, Antonio and Dagiore familiy

Irondo, Simón de 224

Jews

in La Bolsa, 109-112, proposed Jewish state in Argentina, 113-4, 204 see also Anti-Semitism

Jitrik, Noé 23-4, 25, 27

Josefina (Inocentes o culpables) 66-7

Justo, Juan B. 234

Langredo (Teodoro Foronda) 153

Le Bon, G. 201

Leony, Jacob (La Bolsa) 101

Lewin, Boleslau 100, 204

Ley Avellaneda 223

Libro extraño (including parts entitled Genaro, Don Manuel Paloche, Mendez and Hacia la justicia) (Sicardi) 119, 163-90, 207-8; Basques in, 173; British in; Buenos Aires in, 177-8; Civilisation and barbarism in, 168-9, 175-6; depiction of factions in, 183-5; fictional story only background to book's message, 166-7; French in, 172-3; Germans in, 172; immigrants in, 164-5, 175, 177, 185, 190; Italians in, 170-1, language, 187-90; physical and mental abnormalities, 163-4; plot, 163; revolution depicted, 168-9; role of immigration in, 168; social divisions, 163; Spanish in, 174; tension between colonial past and material present, 168; workers' revolt in, 183-4

see also Sicardi, Francisco

Lichtblau, Myron 48, 49, 104, 199

Lillo (La Bolsa) 101-2

Lima 213-5

Littoral Provinces 18, 215, 227

agriculture, 227; immigrants in,
222-3, 226-7; middle class in, 236

Lynch, J. 223

Mackser, Baron (La Bolsa) 98-101, 111

Magis, Carlos H. 204

Malthus, Thomas Robert 53, 54, 200

Marcotta, Tía (Bianchetto) 122, 127

Mármol, José 16, 85, 195

Martel, Julián, pseud. (i.e. José Miró) 49, 50

anti-Semitism, 93-4, 98-101, 110-4, 203, 205; attitude to criollo characters, 101-6, 115; attitude to Europe, 108; background, 92; and cosmopolitanism, 106, 114-5, 130; inconsistency of characterisation, 102-5, 204; prejudice, 94-5; rhetorical observations, 105; views contrasted with those of Alberdi and Sarmiento, 107; xenophobia, 93-4, 106, 114-5 see also La Bolsa

Matadero, El (Echeverría) 15, 29, 194

Máxima (En la sangre) 72, 84-5

Mendez see Libro extraño

Mendez, Angelica (Libro extraño) 164, 182

Mendez, Catalina (Libro extraño) 164

Mendez, Carlos (Libro extraño) 163, 165, 167

Mendez, Dolores (del Rio) (Libro extraño) 163

Mendez, Ricardo (Libro extraño) 185, 186

Merou, M. Garcia 55-6

Milton, John 22

Mimesis (Auerbach) 194

Miró, José see Martel, Julián, pseud.

Mitre, Adolfo 105

Modernismo 187

Muerte y resurrección de Facundo (Jitrik) 23-4

Nación, La (newspaper) 92, 113

Nacional, El (newspaper) 113

Naturalism 48-52, 95, 199

Novels

banned as frivolous, 15; lack of realism in, 9; pro-Unitarian, 15; as sources of information on Argentina, 8-9 
Ocantos, Carlos María 207

Onega, Gladys 7, 49, 112, 139

on Cambaceres, 52, on Libro extraño, 186

Origin of Species, The (Darwin) 18, 195

Ostwald, Simón 100-1

Paca, Doña (Teodoro Foronda) 154-6

Paloche, Don Miguel (Libro extraño) 163 , 171, 172, 189

on Basques, 173; inconsistency as character, 169

Paradise Lost (Milton) 22

Paz, General (Facundo) 21, 26-7, 196

Peregrinación de Luz del Día (Alberdi) 32-43

author's two voices, 34; characters, 35, 36; critics on, 33; degeneration of Europeans in New World, 35-6; effect on Argentina, 32; hybrid genre, 33-4; loss of illusion by Truth, 35; pessimism, 37; plot, 34; view of political freedom in, 37-8 see also Alberdi, Juan B.

Peru 213

Physiognomy 23, 196

Pincencurá (Libro extraño) 178-9, 189

Plate, River 213

Positivism 47, 50, 217 in Bianchetto, 122; in Libro extraño, 177

Pre-determinism 50-1

Prensa, La (newspaper) 113, 138

Progreso, El (newspaper) 17

Promision (Ocantos) 207

Provinces of the Interior 215, 217, 226

Puk, Mr. (Teodoro Foronda) 145

Puk de Antequera, Dr. (Teodora Foronda) 153

Purita, Doña (Teodora Foronda) 141

Quiroga, Facundo (Facundo) 17, 22-4 behaviour, 23; embodiment of Barbarism, 21-2, 25; Jitrik's view of, 23-4; life explains Argentina's history, 20; physical characteristics, 23; represents Federalists, 196; softening of character, 24 see also Facundo

Quixote, Don (Peregrinación...) 35
Racism 23, 41, 201, 205

in En la sangre, 70-1, 78, 82; in Te0doro Foronda, 156-7 see also Anti-Semitism

Ramos, A. 242

Realism 48-9, 52

Rhode, Max 34

Rivadavia 223

Roca, Julio A. 47, 53

Rock, David 206-7, 233

Rodó, Enrique 120, 198

Rojas, Ricardo 33, 92

Rosas, Juan Manuel de 15, 16, 216 in Facundo, 27, 196

Ruano, Silvestre (Teodoro Foronda) 141-2

Rusich, Luciano 7, 55, 112, 132, 136, 165

Saenz Hayes, R. 33

Sáenz Peña Law 234

Saldías, Adolfo didactic fervour, 135, 206; false vision of realist, 136-7; political career, 205; views on immigration, 121 , 126, 129-30, 136-7 see also Bianchetto

Santa Fe Province 227

Sarmiento, Domingo Faustino and Alberdi, 32, 41-2; attack on Barbarism, 18-9, 21, 25, 175 attitude to Rosas, 28-9; and education, 41-2; and extinction of native population, 29; European Romanticism and, 20; faith in Europeanization, 30; and gaucho ethos, 25-6; and immigration, 43; and Martel, 107; racialist 23; and Sicardi, 168; Unamuno on, 28

see also Facundo

San Martín, José de 198

Scobie, J. 183, 230, 236, 240

Ships, refrigerated 219

Sicardi, Francisco 49, 50, 163 ambiguity, 175-6, 178; author's confusion reflects national confusion, 198; comparison with Sarmiento, 168; depicts ideological beliefs at turn of century, 186; and disappearance of negroes and mulattoes, 
181-2; errors about early immigrants, 171; 'el hombre argentino" 181; inconsistency, 175-6, 179-80; language, 187-90; mythified criollo ancestry, 180; and the New Argentina, 181-2; and political refugees, 193; and second-generation immigrants, 171; variety of styles, 186-7; writes primarily of criollos see also Libro extraño

Silver mining 213

Sin rumbo (Cambaceres) 72, 78, 206

Sonajas, Dr. (Teodoro Foronda) 153

Spain and South America 213-4

Spencerian evolutionism 50

Stendhal, pseud. 49

Sud América (journal) 70, 113

Taine, Hyppolite 17

Tartufo (Peregrinación ...) 35, 43

Teodoro Foronda (Grandmontagne) 119, 138-62, 192

autobiographical, 138; British characters, 145-6; British investment, 146; commerce, 158-9; contrast with La Bolsa, 141; criollo characters, 154; depiction of ambition, 148-9; didacticism, 139; differences between generations, 149-50; disdain of lawyers in, 160; documentary importance, 161-2; immigrants in, 141-4, 149-50; individuality of immigrant characters, 142-5; literary value, 162; plot, 139-41; political corruption, 160; popular speech in, 161; portrayal of Anahualpa, 140, 159; publication, 139; racism, 156-7; realism of background, 139-46; second-generation immigrants, 151, 152

see also Grandmontagne, Francisco; Foronda, Teodoro

U.S.A. 10, 41, 200

Unamuno, Miguel de 28, 195

Unitarios 28, 84, 215

bias towards European immigration, 15; policy for agriculture, 18; portrayal in novels, 15-6; support of immigration, 15

Urquiza, General 216

Valera, Juan 139

Valverde, Enrique (Libro extraño) 167

Valverde, Germán (Libro extraño) 183, 186

Vicharo, Don Carlos (Teodoro Foronda) 154

Viñas, David 98, 112, 192, 204

Zola, Emile 50-2, 57, 173

Zole (La Bolsa) 96

Zolaesque Naturalism 85, 95, 188

Zum Felde, A. 197 


\section{CONTENTS}

ABSTRACT 5

ACKNOWLEDGEMENTS 6

INTRODUCTION

PART ONE: THE PRE-IMMIGRATION PERIOD 13

I. "Facundo: Civilisazión y barbarie" $\quad 15$

II. "Peregrinación de Luz del Dia” 32

PART TWO: THE IMMIGRATION PERIOD: THE ANTI-IMMIGRANT NOVELS 45

I. Background to the Literary Scene $\quad 47$

II. “Inocentes o culpables" 53

III. "En la sangre" 70

IV. "La Bolsa" 92

PART THREE: THE IMMIGRATION PERIOD:

THE PRO-IMMIGRANT NOVELS 117

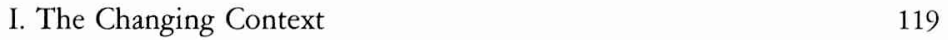

$\begin{array}{ll}\text { II. "Bianchetto" } & 121\end{array}$

III. “Teodoro Foronda" 138

IV. "Libro extraño" 163 
Footnotes to Part One, Two, Three

and Conclusion

I. The Colonial Era

II. Independence and the Struggle for Unity

III. The Transformation of Argentina The Years of Prosperity

1. The International Situation and Argentina's Ability to Respond to It

2. The Main Developments Related to the 'Transformation of Argentina'

II. Economic, Social, and Political Changes

1. The Provinces of the Interior

2. The Provinces of the Littoral

3. The City of Buenos Aires 



\section{BIBLIOTHECA IBERO-AMERICANA}

1 Max Uhle, Wesen und Ordnung der Altperuanischen Kulturen. $132 \mathrm{~S}$.

2 Hans Horkheimer, Nabrung und Nabrungsgewinnung im vorspanischen Peru. $160 \mathrm{~S}$.

4 Peter A. Schmitt, Paraguay und Europa. Die diplomatischen Beziehungen unter Carlos Antonio López und Francisco Solano López 1841-1870. 368 S.

5 Rudolf Geske, Góngoras Warnrede im Zeichen der Hekate. 135 S.

6 Cary Hector, Der Staatsstreich als Mittel der politischen Entwicklung in Südamerika. $226 \mathrm{~S}$.

7 Fritz Hoppe, Portugiesisch-Ostafrika in der Zeit des Marquês de Pombal (17501777). $360 \mathrm{~S}$.

8 Juan Carlos Agulla, Soziale Strukturen und soziale Wandlungen in Argentinien. $280 \mathrm{~S}$.

9 Friedel Maurer-Rothenberger, Die Mitteilungen des Guzmán de Alfarache. 131S.

10 Georg Thomas, Die portugiesische Indianerpolitik in Brasilien 1500 bis 1640.244 S.

11 Ulrich Fleischmann, Ideologie und Wirklichkeit in der Literatur Haitis. $312 \mathrm{~S}$.

12 Ronald Daus, Der epische Zyklus der Cangaceiros in der Volkspoesie Nordostbrasiliens. $156 \mathrm{~S}$.

13 Martin Gerbert, Religionen in Brasilien. $128 \mathrm{~S}$.

14 Käte Harms-Baltzer, Die Nationalisierung der deutschen Einwanderer und ibrer Nacbkommen in Brasilien als Problem der deutsch-brasilianischen Beziehungen. 248 S.

15 Thomas Becker, Die deutsche Mexikopolitik 1913/1914. 352 S.

16 Klaus Rother, Wirtschaft und Berufserziebung in Venezuela. $200 \mathrm{~S}$.

17 Gustav Siebenmann, Die neuere Literatur Lateinamerikas und ibre Rezeption im deutschen Spracbraum. $96 \mathrm{~S}$.

18 Reinhard Peterwerth, Das Vertragswerk des Zentralamerikanischen Gemeinsamen Marktes. $134 \mathrm{~S}$.

19 Armando Abad Franco, Parteiensystem und Oligarchie in Ecuador. 292 S.

20 Renate García y Más, Die Biblioteca Nacional in Madrid. 128 S.

21 Konrad Tyrakowski, Ländliche Siedlungen im Becken von Pueblo-Tlaxcala (Mexiko) und ibre Entwicklung im 19. und 20. Jabrbundert. $120 \mathrm{~S}$.

22 Waldo Ross, Problemática de la literatura bispanoamericana. $76 \mathrm{~S}$.

23 Richard A. Cardwell, Juan R. Jiménez: The Modernist Apprenticeship 1895-1900. $329 \mathrm{~S}$.

24 Arnold Spitta, Paul Zech im südamerikanischen Exil 1933-1946. 292 S.

25 Hans Haufe, Funktion und Wandel christlicher Themen in der mexikanischen Malerei des 20. Jabrbunderts. Textteil 232 S., Bildteil 136 S. (323 Abb.)

26 La emigración europea a la América Latina: Fuentes y estado de investigación. $268 \mathrm{~S}$.

27 Gerónimo de Vivar: Crónica y relación copiosa y verdadera de los reinos de Chile (1558). Edición de Leopoldo Sáez-Godoy. 368 S.

28 Nicolás de Valenzuela, Conquista del Lacandón y conquista del Chol. Relación sobre la expedición de 1695 contra los Lacandones e Itzá según el „Manuscrito de Berlin“. Edición y comentario de Götz Freiherr von Houwald. Texto 510 S., Comentario $200 \mathrm{~S}$.

29 Evelyn Fishburn, The Portrayal of Immigration in Nineteenth Century Argentine Fiction (1845-1902). 260 S. 



healthy, even redeeming, influence) and Barbarism (those regarding it as a disruptive, barbaric invasion). The Argentine Novel progresses towards new positive attitudes, in which the doleful strictures of biological determinism give way to a more accommodating belief in the influence of the environment. At the same time, this work records a radical shift in the country's ideological outlook from cosmopolitanism to nationalism. Contrary to previous interpretations, which considered the portrayal of immigration to be realistic and objective, Dr. Fishburn concludes that it was, in fact, treated in a manner that is narrow, rhetorical and prescriptive. A stereotype is created of an immigrant who arrives poor and becomes rich, and who is evaluated on racial and cultural bases. This reflects less the living experience of the immigrant than it gives an insight into the mixed reactions that immigration elicited from some of the leading intellectuals of the country. 
. 